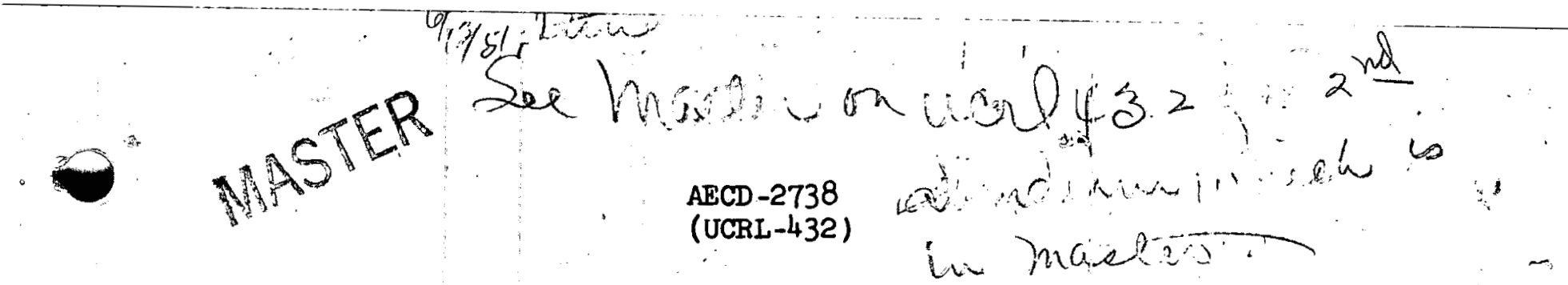

UN I TED STATES A TOM IC ENERGY COMMISSION

\title{
CHEMICAL PROCEDURES USED IN BOMBARDMENT WORK AT BERKELEY
}

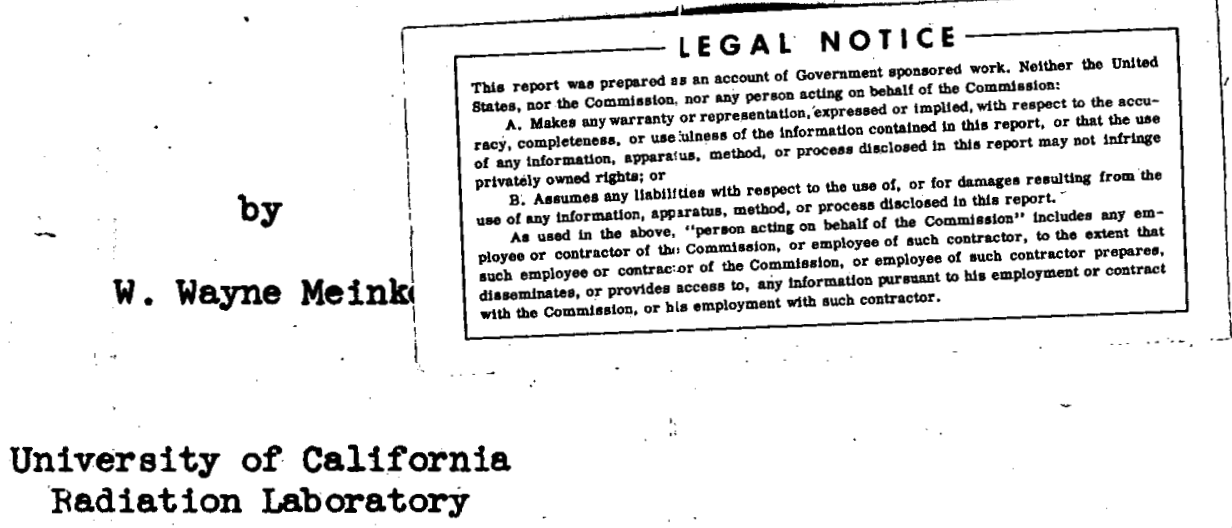

\begin{abstract}
Date of Manuscript: August 30, 1949
Date DecIassified: October 15, 1949

Issuance of the document does not constitute authority for declassification of classified copies of the same or similar content and title and by the same author.
\end{abstract}

\section{Reproduced direict from copy as submitted tothis office.}

Technical Information Division, ORE, Oak Ridge, Tennessee AEC, Oak Ridge, Tenn., 3-16-50--900-A20399

Reprinted AEC, Oak Ridge, Tenn., 3-16-51--425-W11165

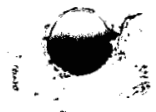

Printed in U.S.A.

PRICE 90 CENTS

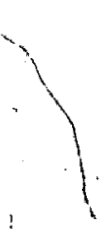

35.001

$a$ 


\section{DISCLAIMER}

This report was prepared as an account of work sponsored by an agency of the United States Government. Neither the United States Government nor any agency Thereof, nor any of their employees, makes any warranty, express or implied, or assumes any legal liability or responsibility for the accuracy, completeness, or usefulness of any information, apparatus, product, or process disclosed, or represents that its use would not infringe privately owned rights. Reference herein to any specific commercial product, process, or service by trade name, trademark, manufacturer, or otherwise does not necessarily constitute or imply its endorsement, recommendation, or favoring by the United States Government or any agency thereof. The views and opinions of authors expressed herein do not necessarily state or reflect those of the United States Government or any agency thereof. 


\section{DISCLAIMER}

Portions of this document may be illegible in electronic image products. Images are produced from the best available original document. 


\author{
T. Tayne, Binice \\ Department of Chemistry, Radiation Laboratory \\ University of Califor nia
}

In the Nuolear Chemistry Group of the Untversity of Californie Radiation Iaboratory, chemists have for the past several years been using many ohemioal procedures, separating at one tim or another about 75 of the 96 elements in the periodic table. These prooedures vary from simple single step processes requiring less than a mimute to tedious week long separations.

With now high energy aooelerators either being plamed or being bullt in many plaoes, it has seomed worth while to oomplie the prooedures used at Berkeley. Way times these prooedures can be used exactly as written but more often they w11l serve only as a starting point from which the individual can develop a prooedure more suitable to his particular problem. Their great advantage 18 that thoy have aotually been used in bombardment work for separating a partioular elemont from a 21 other el oments present.

This compliation begins with somo general remarks applicablo to chemical separations from targets that have been bombarded with hich onergy partioles. The remaining pages are indexed by atomito number and procedure number, $0.8 ., 40-1$ is the first procedure for eiroonium. Procedures for eloments 90 and above are oxcluded ponding deolassifioation.

A brief explantion of the headings used is probably in arder. The yiold and degreo of purffication listed for cach separation have in many cases been determined experimentally while in other oases they are only the best guess of the obomist. These values are inoluded as a general guide to the person unfamiliex with the chemistry of a partioular element to help sim judge the applioability of the prooedure to his wark. Tho time of P-18-293 
separation in general refors to the time required to perform the operations listed; for fission work it does not include time for solution of the target. Any speoial equipment required for the procedure has been noted.

The portion of the heading reading "Procedure by" should actually read "Procedure used by". It is not foasible in a report of this kind to acknowledge all the souroes of information that have gone into the formulation of these procedures. Many are adaptations of the fission product prooeduros $(1)$ whilo others combine experimental data with data

1. RADIOCHFICAL STUDIES: THE FISSIOE PRODUCTS, Voluwo 9, Div. IV of the National Nuolear Energy Series, NoGraw-Hill Publlshing Co. (1950).

presented in standard books on analys is.

The type of bombardmont for whioh oach separation has been used is also noted in the hoading. There no onergies a ro indicatod, one may assume the procedure applicable to full energy bombardments. The full energy particles of the acoelerators used are:

184" oyolotron: 388 Hev alphas, 348 hev protons, 194 Hov douterone 60" oyclotron: $37 \mathrm{Kr}$ al phas, $9.5 \mathrm{Hor}$ protons, $19 \mathrm{~kb}$ deuterons Linoar acoelerator: $32 \mathrm{Mev}$ protons 57" cyolotron: $26 \mathrm{Her}$ protone

The purpose of this compilation was to male for our laboratory a worlding file to whioh now prooedures might be added as they are doveloped. The procedures wore writton up by the ohemists using them and odited by the author. Mnen there were variations in target matorial, time for separation, or type of bombardment, 'separate procedures whioh may differ only slightly were inoluded. This was dono in ordor that eaoh procedure

- inight be as complete os possible within itself.

$P-18-294$ 
The euthor wishes to express his sincere thanks to the following chemlst sho have made this compilation possible: N. E. Ballou, George T. Barton, Roger E. Batzel, Daniel P. Brooks, Stanley V. Cestner, T. C. Chu, Wm. W. Crane, Richard W. Fink, Robert L. Folger, 1 l Ghiarso, Robert H. Goeckermann, Herry Hicke, Jack M. Hollander, H. H. Hopkins, Jr., Earl x. Hjde, Detid G. Karraker, Charles A. Levine, Robert C. Lilly, Manfred Lindner, David Z. Llppmann, L. B. Magmsson, Luls Harquez, Tm. R. MaDonoll, J. M. Miller, Daniel Miller, Robert A. Neumann, Henry M. Neuwann, Amos S. Newt on, William C. Orx, Donald 4. Orth, Charles A. Prohaska, John O. Rasmussen, Sheldon Softiry, Darothy B. Stewgrt, Donald C. Stewart, Kenneth Street, Jr., Stanley G. Thowpson, Geoffrey Filkinson and Richard Nolfe.

It is a pleasure to thank Dr. I. Perlman for his advice and assistance in the preparation of this compilation. The careful nork of Mise Virginia Hempel in typing the manuscript is also greatly appreciated. This compliation was sponsored by the Atomic Energy Comission. 
General ohemical separations for the mass speotragraph.

For the m.s., it is nocessary to have the material in almost carrier-freo form-from . 2 ug to $100 \mathrm{ug}_{\mathrm{G}}$ beling the range of stable carrier allowed. Purity is not ossential, as far as deoontamination is ooncerned, since the mass spectrograph does this. It is necessary to got the sample in a small volume, with a minimum of carrier and a minimum of aocompanying salts.

To aooomplish this for most elements is quite diffieult, but mothods that oan be used are suggested. An lon-exohange colvm gives the ideal product. Woarly all other mothods depend on the carrying properties of homologues for initial separation from the target, with subsequent separation of the carrier. For example, Ba may be carried on Po, and left in soln by ppt PoS. Tri-positive ions may be carried on $\mathrm{Fo}(\mathrm{OH})_{3}$, and the Fe extracted with other, loaving a carrier free solution.

A rery good separation of Bi may be obtained by plating the B activity - (ohemioelly) on $\mathrm{HI}$ foil, dissolving the $\mathrm{MI}$ in $\mathrm{HHO}_{3}$, and carrying the $\mathrm{BI}$ way on $\mathrm{La}(\mathrm{OH})_{3}$. Bi is then separated from La by ppt 50 ng of Bi with $\mathrm{H}_{2} \mathrm{~S}$ from a very small volume of solution.

Electroplatine offers many unexploited possibilities, but should oertainly not be lost sight of, simply beoause it has not been used. For man motals. it is possibly the best available mothod.

D. G. Karraker 
Exerpts from Thesis on Spallotion Producto of Arsenic with

190 Hev Deuterons - (UCPL - 312) H. H. Hopkins, Jr.

\begin{abstract}
Abstraot: Purified arsenic has been bombardod with 190 Mev deuterons. Following ohemical separation of chlorine and the 11 elements chromium through selenium, an analys is of the radioactivitios in each fraotion showed the presenoe of a total of 40 isotopes.
\end{abstract}

\title{
Bombardment Procedure:
}

For the purpose of bombardment, several hundred milligrams of granular arsenic metal were wrapped with one mil platinum foil. The resulting envelope was approximately $25 \mathrm{~mm}$ long, $3 \mathrm{~mm}$ wide, and $2 \mathrm{~mm}$ thiok. This envolope was clamped along one edge to a standard copper mount whioh is scromed to a water-cooled target head. This head moves into the oyclotron ohamber so that the forward edge of the target meets the deuteron benm.

The duration of a bombardment was usually one hour. The beam attainable was about one mioroampere, but costly experionce proved that the dissipation of the effective power caused rolatilization of the target. Cutting the beam intensity to $30 \%$ oliminated this 108 of arsenic as proved by weighings made before and after bombardment.

After bombardment the envelope containing the arsenio was taken from the holder, and the arsenio removed. The pleoes were ground in a hand mortas, and the resulting arsento powder used for ohemionl operations.

\section{Chemionl Separations:}

The separation of the' isotopes produced by spallation into elemental fraotions was accomplished by chemioal procodures. First the target was dissolved in nitrio acid. Second, inactive carrier ions wore added, corresponding to those elements we are conoerned with. Finally, separations were conduoted by distillations, solvent extraotions, and preoipitations.

The degree of separation required of the chemioal procedures is determined by the radiation characteristios of the isotopes of the different elements and the relative intensities of the radiations. Thus, to identify conclusively two isotopes of different elements, of similar half-lifo, radiation properties, and yiold, a separation of about fifty to one is required. In the case that the isotope of one element deoays by oleotronoapture and the othor by beta omision, then for the latter a separation frotor of only five is required, due to the relative differenoes in counting effiolonoies. Correspondingly, tho olemental fraction of the eloctroncapturing isotope must be separatod by a greater factor, of the order of 500, sinoe small amounts of the beta emitter would introduce considerable error in counting the $x$-rays of the electron-oapturing isotope. For cases where the half-lives diffor considerably, other 5 gonsiderations must be applied. For example in the iron fraction only 47 day $\mathrm{Fe}$ is observed, while the longost gallium period is $3.3_{9}$ days. Thus whereas gallium isotopes aro formed in far greator yield than Fe 59 , no chemical sepgation is neoessary. since all pallium 180 topes will be dead before the Fe has docayod appreoiably. 
The quantity of a radioelement present is of the order of $10^{-13}$ mole. Thus, while this amount would underco distillation and oxtrnotion just as milligram amounts of the element, most procipitations could not oocur since solubility products would not be exceeded: Therefore milligram amounts of the olements are added to function as carriers. The exchange of the radioactive isotopos with ions of the added carriers is bolieved to be complete in hot aold solution. No ovidenoe such as oross contamination or widely varying specifio activity indicated that this was not the casc. Another roason for carriers is to minimiso adsorption on precipitates.

A description of the sovaration of the elements into three groups will bo proscnted, followed by a discussion of spocific mothods for indivichal olemonts.

1. Tho Germaxium, Arsenio, Selenium Group.

These thrce elemont may bo distilled from 9 I hydrobromio aoid and bromine as the bromides. An alternative is to sublimo the arsenio before dissolution in nitrio aoid. ithen this is done arsenio and radiosolenium soparate from the other radiooloments. Germanium may subsequontly be soparated from the residue by distillation with hydroohlorio acid.

This group may also be prooipitated by hydrogen sulfide in aold solution and subsequently dissolvod in ammonium hydroxide. The olear filtrate will contain only the thio-salts of gormanium, arsenic, and selenium.

2. Iron and Gallium.

Theso oloments aro rcadily extracted into other, from 5.5 to $6 \mathrm{~N}$ hydrochloric aoid. Iron must bo in the forric state. Washing tho organio layer with more hydrochloric acid removes other groups which oxtraot to a lossor extent.

3. Chromium, Manganoso, Cobalt, Hickel, Coppor, and Zine.

This group oan be separated from the first by the use of ammonive sulfido. The sulfidos aro usually dissolvod in oonoontratod nitrio aoid in the presonoe of solid potassium chlorate, and subsequent procedures scparato tho olemonts one at a timo.

$8 / 11 / 49$

P-18-149 
Diagram of Separation Procoduros.

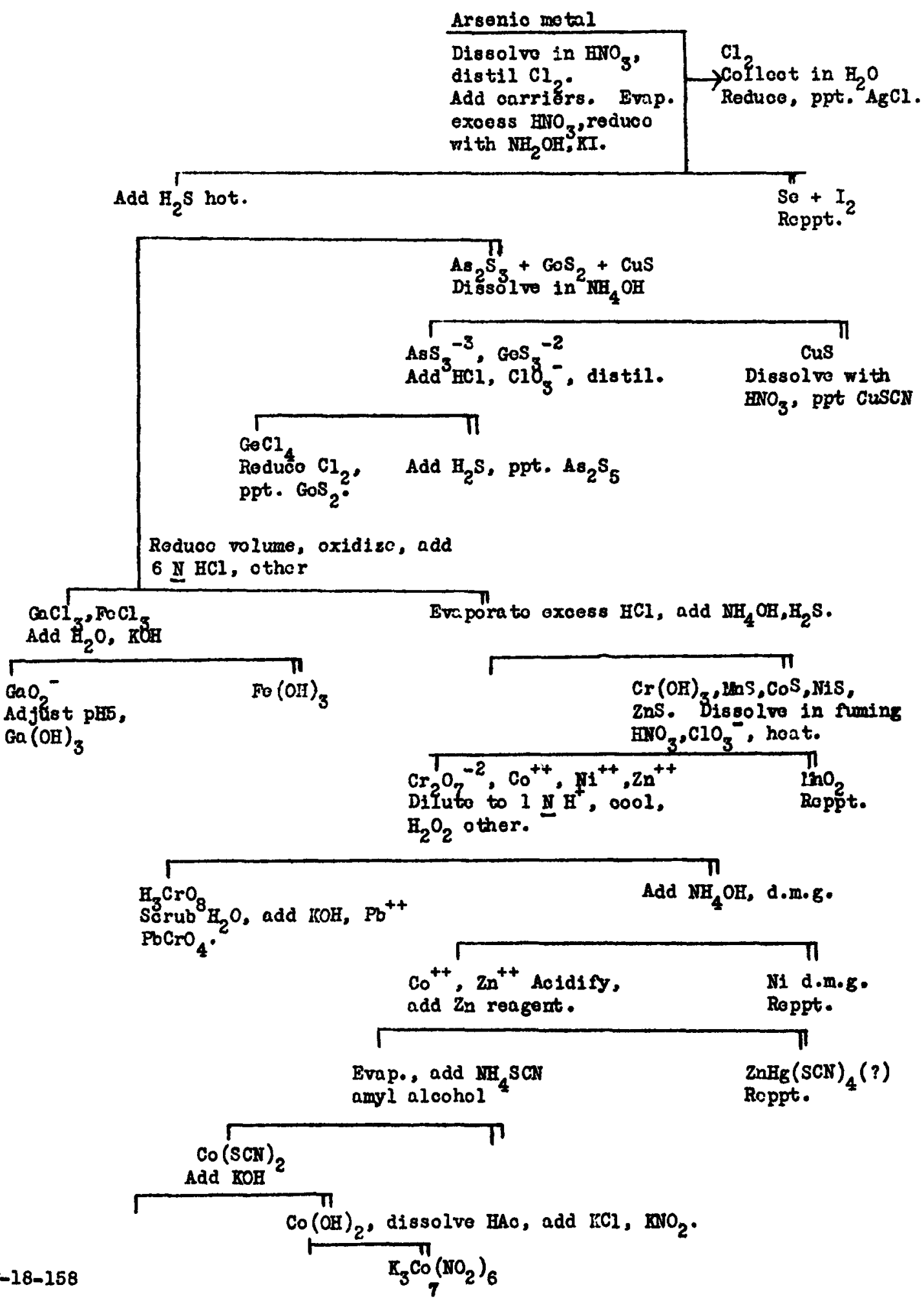
Evaporato oxcess $\mathrm{HCl}$, add $\mathrm{MH}_{4} \mathrm{OH}_{2} \mathrm{H}_{2} \mathrm{~s}$. Add $\mathrm{H}_{2} \mathrm{O}, \mathrm{KOH}$ 
General 3

Exorpts from Thesis on Charaoteristics of Bismuth Fission with

High Energy Partioles - (UCRL 251) - Robert H. Goockermann

\section{Introduotion:}

The yields of nuolides resulting from 190 Mer deuteron fission of bismuth were determined by studying the aotivities of 27 elements from $\mathrm{Z}=20$ to $\mathrm{Z}=63 \ldots \mathrm{Ca}, \mathrm{Cr}, \mathrm{Fe}, \mathrm{Hi}, \mathrm{Cu}, \mathrm{Zn}, \mathrm{Ca}, \mathrm{As}, \mathrm{Se}, \mathrm{Br}, \mathrm{Rb}, \mathrm{Sr}, \mathrm{Y}$, $\mathrm{Zr}, \mathrm{Cb}, \mathrm{1b}, \mathrm{Bu}, \mathrm{Pd}, \mathrm{Ag}, \mathrm{Cd}, \mathrm{Sb}, \mathrm{T} \theta, \mathrm{I}, \mathrm{Cs}, \mathrm{Ba}, \mathrm{Ce}$, and Eu.

Bombardment Technique:

The ciroulating beam of the 184-inch frequenoy-modulated oyclotron was used almost exclusively because its intensity is much greater than the deflocted beams. The average beam is of the order of one microampere, but nelther it nor its day-to-day variations were measured or known acourately. Therefore it wagneoessary to use an internal monitor--in this case $67 \mathrm{hr}$ $B^{-}$-emitting $10^{9} 9_{--1 n}$ eaoh bggbardment and measure all yields relative to it. The absolute yield of 16 gas later determined using a defleoted col-

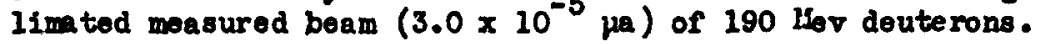

Bismuth stripe $0.1 \times 1 \times 3$ om were maohined from an ingot obtainod from the American Smolting and Refining Company. Speotrographio analyses shomed the absence of amy impurity that might interfere with the measurements.

\section{Chomioal Procodures:}

The irradiated portion of the bismuth was dissolved in hot $6 \mathrm{I} \mathrm{BrO}_{3}$ and stored in a closed oslibrated glase container. Aliquots of this solution were used for the study of the activities of a partioular element. If tor amounts of oarrier solutions had been preparod, by roighing out som suitable compound to contain $10 \mathrm{mg} / \mathrm{ml}$ of the element. (A fer of those oarrier solutions have been standardized and found to be socurate within 10\%.) One or tio ml of this solution of an olement was added to the aliquot of tho bismith solution as carrier for the radioactive isotopes present, precautions to insure exchenge of active and inaotive toms taken in some cases, and the element purifiod from all others which would interfere in the radioaotivity measuroments. Radioeotive isotopes of most of the elements up to astatine are probably produoed to some extent but the predominant flseion produots are in the caloiv (20) to europium(63) region and the predominant spallation produote are in the hafnium(72) to astatin (85) reglon. From the deternined fission oross seotion it is estimated that the yiold of spallation produots is several times as great as the yield of fission products. Part or all of the purified elemont was then preoipitated as a weighable compound, filtered through a Hirsoh runnel on a tared $n$ om diameter filter paper and the ohemical yield doterminod. The filter paper is washed and dried like the prooipitate it will oarry prior to taring. Is st of the ohemistry used was adapted from fission produot prooedure reports to appear as part of the National Fuolear Bnersy Series. The procedures are outlired hero primarily beoause no compilation of them is yet generally available. The amounts of scavengers used are only approximato. All preofpitates were separated by centrifugation except the final one in eaoh case. 
Exerptofrom Thes is on Nuclear Reactions in Antimony with High

Energy Particlos - (UCRL-143) - Manfred Lindner

Irradiation with 200-Mer deuterons and 400-kev alpha particles from the 184" cyclotron has, in general, given $r$ ise to so large a number of radioactive products that rather elaborate chemical procedures had to be worked out in order to identify these products. Thus it has been found in the case of antimony targets that activities were produced which differ in mass from the target atoms by 36 units, and in atomic number by 15 units. Of course, a multitude of isotopes in between these limits was also formed.

The elements listed below include those which were identified from the complex mixture of spallation products of high-energy deuterons and alpha

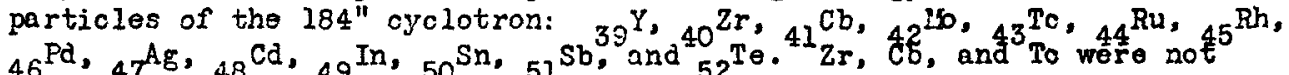

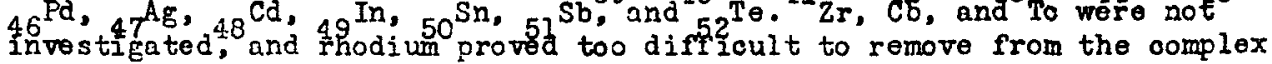
mixture. However, the remaining elements, $\mathrm{Y}, \mathrm{Mo}, \mathrm{Ru}, \mathrm{Pd}, \mathrm{Ag}, \mathrm{Cd}, \mathrm{In}, \mathrm{Sn}$, $\mathrm{Sb}$, and Te were investigated. Since many of the products of lower atomio number ( $Y$, Mo, etc.) were found to be formed in exceedingly low yield, it was necessary to effect complete separation of a given element followed by several repurifioation steps. A known weight of carrier (usually twenty milligrams in the form of a solution of a readily soluble salt) was always added to the gross mixture of activities before chemical separations were made. This procedure insures against the adsorption of any tracer activity on foreign precipitates. The following procedure was found to work satisfectorily for $t$ ¿ $s c[\cdots$ tion of those olements listed in table I except for $\mathrm{Zr}, \mathrm{Cb}$ and $\mathrm{Tc}$.

The dimensions of the metallic antimony targets vere about $1 \mathrm{~mm} x 2 \mathrm{~nm}$ $x 30 \mathrm{~mm}$, weighing about 0.45 grams.

The procedures given below serve to isolate a given element in a state free from any contaminating activities. In many instances, the procedures were not suitable to the determination of periods of the order of one-hour half-life, due to the time involved in separation and purifioation. In such instances, it was usually necessary that initial efforts be concentrated in isolation of such a short-iived activity or that the ohomical procedure be shortened if the separation and decontamination from other elemests is not seriously impaired.

\author{
$8 / 11 / 49$ \\ P-18-172
}


Exerpts from Thosis on Radioaotivities Producod in the Platinum Group by Bombardmont of Uranium with 400 KeV Helium Ions

(UCRL-123) - Hohard D. Wolfo

Abstraot:

The purpose of the investigation was to determine the yield of radioaotivities of the platinum group motals (ruthenium, rhodium, pciladium, osmium, iridium, and platinum) produced whon natural uranium is bombardod with 400 liev holium lons. The reason for interest in the yields of these motals is that the last throe ilo in a region where the plot of yiold vs. mass number may ohange from a fission-yield ourve to a spallation-yiold ourve. In addition, the first throo lie in a rogion which should indicate whothor the oenter of the ourve has a dip (as does the slow-noutron fissionyleld ourvo), or a singlo maximum indicating symmetrical fission (as in the oase of biamuth and thorfum).

Padioohomistry of the Platinum Elements

The ohomistry of the six platinum eloments ${ }^{\mathrm{Pu},} 45^{\mathrm{Ph},} \mathrm{P6}^{\mathrm{Pd} \text {, and }} 76^{\mathrm{Os} \text {, }}$ 77. Ir, 78 Pt is notoriously complex. Thoir separation, Purifioation, and eleotron oonfiguration of the first throe partially fills the $4 d$ orbit, with the possibility of adding 10,9 , and 8 olootrone respeotively for ruthonium, rhodium, and palladium in ordor to $f 111$ out the 5s and 5p orbits and form the stable noble-gas configuration of $54^{x 0}$. Similarly, osmium, Iridium, and platinum partially fill the 5d orbit, and oan add 10,9 , and 8 eleotrons respeotively, filling the 6 and $6 \mathrm{p}$ orbits to attain the noble sas struoture of RR. Beosuse of this eleotron struoture, all six elomonts onter into a vast number of coordination complexos, with almost any radioal or olemant, oha rgod or neutral, which can furnish an unpalred olootron. Thelr ohemistry 18 thus oharacterized first by extensivo oomplex formation in whioh all - Ix bohave very similarly and are thorefore difficult to separate; and secondly by difficulty in getting the olements into solution, and onoo they aro in solution, further diffioulty in getting them quantitatively out of solution.

A number of satisfotory sohemes are presented in the liferature for quantitative and qualitative determination of these olomonte." Howevor,

4. Analysis of Platinum lotals, Bur. of Standards Soi. Papor No. 532 (1936); Jow. of R6s. 3, 993 (1929), 6, 421 (1931), 9, 547 (1932); Jour. Am. Chom. Soo. 48, 2493, 2507 (1926), 51, 175 (1929), 52, 42 (1930); Ind. and Eng. Them. Anal. Ed. 8, 141 (1936), 9, 420 (1937); Am. Lifneral 22, 1016 (1937); liforoohem. 24, 20 (1938).

thoso sohcmos are genorally inapplioablo, without oxtonsivo modifioation, to flssion produot procodures. In the first place, the olassic mothods aim at soparating the platinum metals from oros or naturally ooourring sourcos, whore contaminating substances are relativoly fow, and aro fairly 
well knorm as to typo. Seoondly, these sohomes ain at quantitative determimation of the platinum elements, entalling precise, time consuming, cumbersome, and involved ohemical prooedures.

The fission product prooedure for these ol ements has a different aim. Although 100\% recovery of the $81 x$ elements sought is not required provided their chemioal yield can be ascertained, decontamination faotors from other radionotive elements must often be as large $\mathrm{cs} 10^{\circ}$ and ometimes larger, since aotivities in osmium, iridium, and platinum are very low compared to aotivities of contaminants. In addition, separation must be made not from a few known elements oocurring with these metals in natural ores, but from the majority of the eloments in the periodio table. Finally, the separations performod must be relatively speoifio and rapid, in order to permit observation of the shorter-lived periods.

With the foregoing requirements in mind, the literature was surveyod for reactions whioh might be combined to aohievo the separations desired. Fiseionproduot procedures for ruthenium and palledium aro extant. That developed for rnodium was insuffioient, in that no separation from iridium had been provided for. No f1ssion-produot procedures oxisted for osmium, iridium, and platinum, 2lthough the standard qualitative mothod of distililing osmium tetroxide seemed adaptable to the requiremonts. Thus the soparation of Iridium, rhodium, and platinum oomprisod the ohief problems.

If soemed likely that the pyridine separation for rhodium developed by Ballou might be adaptable also to iridium, eince the two metals behare almost

5. Ballou, N. E., Plutonium Project Report CI 1312, An-X (1ny 1945).

identioaldy in their chemioal reactions. Further reference to the old literature established the existonoe of a number of pyridine complexes

6. Delépine, H., Compt. Rond. 146, 1267 (1908), 158, 60 (1911); Bull Soo. Chim. (4) 3, 906 (1908), (4) 9, 710, 771 (1911)/3 Ann. Chim. Phys. (9), 7. 277 (19I7), (9) 19, 5, 145 (1923); A. Gutbelex and D. Hoyermann, Zeit. Anorf. Chem. 89, 340 (1914).

of Iridium. After many weeks of trial and arror, the proper oonditions were discovored for simaltaneous formation of pyridine complexes of rhodium and iridium, and for their extraotion into excess pyridine. Tho wothod was finally tested using active iridium as a traoer, to prove the results. The method is partioularly elegant sinoe it eeparates in one step from the bulk of uranium in the solution, and from all of the non-platinum group fission produot except silver. 8ubsequent soparation of rhodium from iridium was achieved by adapting the method of Gichrist and Fichers,

7. Gilohrist, R., and E. ijichers, Jour. Am. Chem. Soc. 57, 2565 (1935).

precipitating rhodium motal from the boling sulfate solution by addition of titanous chloride, leaving the iridium in solution.

P-18-209 
Based on the use of ethyl acetate to extract platinum, a number

8. Hobling, H., Ber. 67, 773 (1934).

of experimonts vere performed to determine optimum conditions for platinum extrnction. Clean extraotion of platinum reduoed by stannous ohloride was attained above four normal acid concentration. Butyl acetato was found preferable to ethyl acetato because of lower water solubility.

Tho targot for each bombardment consisted of a small sirip of uranium motal, of natural isotopio composition, 0.04 inches thick and about two inohos long. It was mounted on a copper holder, which wes inserted on $a$ probe into the raouum chamber of the cyclotron such that the boam struck the leading edge of the target perpendicular to the metal strip. After bombardment and removal of the target from the copper backing plate, the unbombarded portions wore cut off in order not to enoumber the ohemistry with too much inactive material. It was found desirable to cloan the target in nitrio acid and keep it in an eracuated desiocator until just prior to bombardment, to prevent formation of the difficultly soluble oxides of uranium.

Chemioal yieid was determined in each case by adding a known amount of standardized carrier at the start (oa 20 mg for each element), and by determining the weight of each element rocovered. Osmium, iridium, platinum, ruthenium, and rhodiun were determined as the elements by preoipitation with magnesium. Palladium was detormined as $\mathrm{Pd}\left(\mathrm{C}_{4} \mathrm{H}_{2} \mathrm{~N}_{2} \mathrm{O}_{2}\right)_{2}$, the palladium oompound of dimethylglyoximo. Earium is determinod $a^{4} \mathrm{HCl}_{2}^{2} \cdot \mathrm{H}_{2} 0$. 
Spallation nf copper with 350 lier Protons - R. E. Batzol

The bombarded copper foil is usually dissolved in the minimum amount of concentrated nitric acid. Knorm amounts of carriers are added and preoipitations are carried out from this solution. The known amounts of carriers are added in order that a quantitative estimation can be mado as to the amounts of orieinal cerrier lost during chemical separations, this being also a mosure of the amount of radioactivity lost.

In general the degree of chemjoal purification necossary depends on the yield and counting efficienoy/the specifio isotopes formod during bombardmont. If the isotope is formed in high yield and has a high counting effioienoy the degree of chemical separation noed not be too high, but if the element is formed in low yield or has a low oounting efficienoy speoial preoautions must be taken. To increase the degree of radiochemioal purity holdback carriers are added. The holdback carriers dilute the activity of any elemental fraction which has a tendency to oo-precipitate or occlude during preoipitation. Another method of increasing radioohomioal purity is the use of scavenging agents. With the desired element in solution under conditions whioh will preoipitate one or more of the possible contaminants, omall amounts of carriers for the interfering elements are added and repeated precipitations made.

In order to remove the majority of the solids from the solution, the copper is precipitated from a 1 IN HCl solution free of oxidizing agents. Sulfide preoipitations can be used as a volum roduotion stop sinoe most of the elements below copper which are of interest a re insoluble in ammonioal sulfide. The chemioal prooeduros are usually adaptod to wet speoiflo conditions depending on the order in whioh elemental fractions are to be romoved.

The following is an example of a separations sohom for one speifie
bombardments 


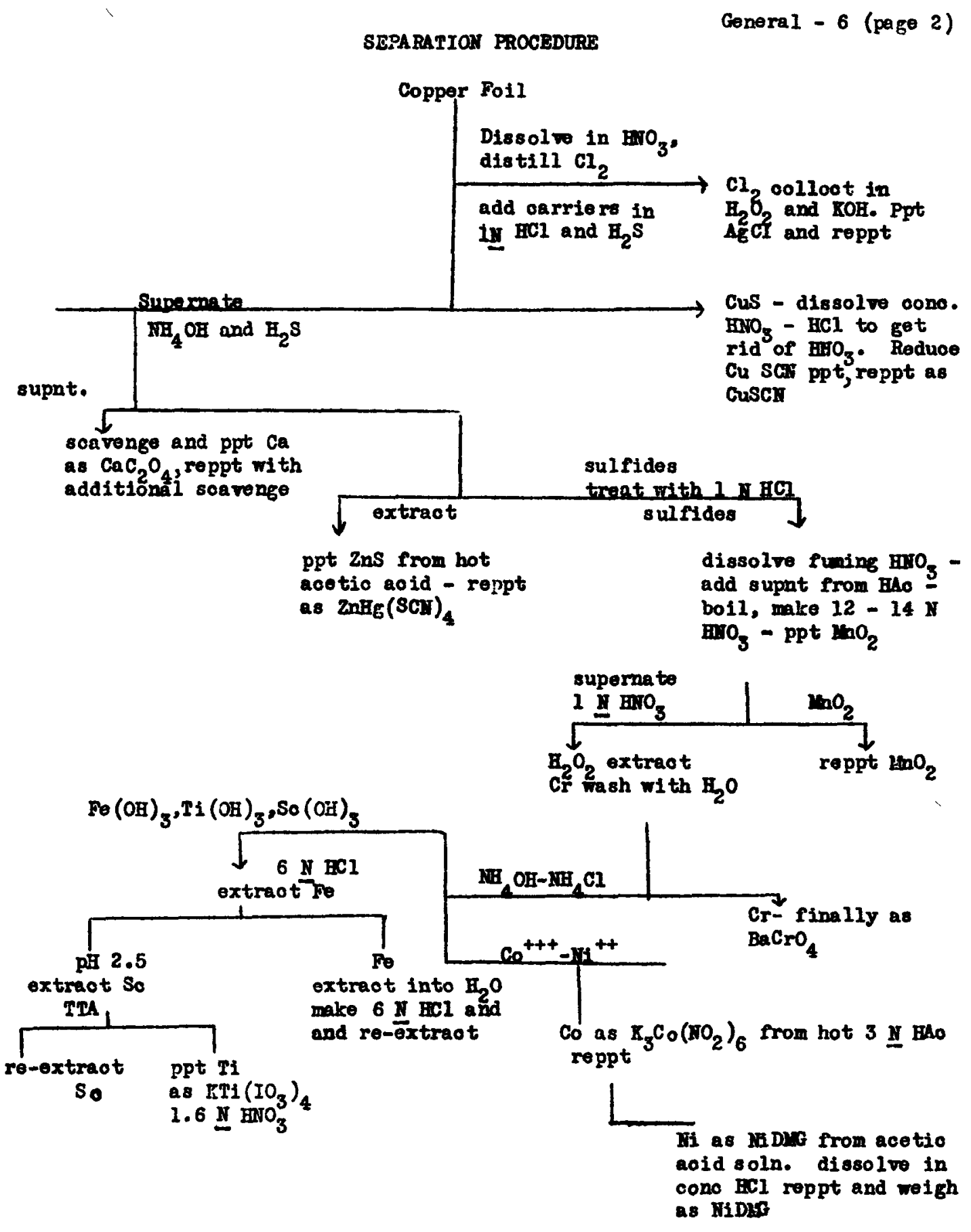

$8 / 16 / 49$

P-18-193 
Fission and Spallation of Uranium with High Energy Particles - R. Folger

General Remarks:

(1) By proper choice of solvents, a number of elements may be removed from a single target soln., e.g., when looking for Os, $I$, and $B r$ the target should be dissolved in $\mathrm{BCl}$ ( $\mathrm{NO}_{3}^{-}$excluded.) After solution, these elements may be distilled from aqua regia by add'n of $\mathrm{HNO}_{3}$ and heating.

(2) When looking for $\mathrm{Ag}, \mathrm{Ge}, \mathrm{Sr}$, the target should be dissolved in cono. $\mathrm{HNO}_{3}$.

(3) Ppting uranium by passing in $\mathrm{NH}_{3}$ renoves a large group of elements in the form of ammonia oomplexes (Co, $\mathrm{Ni}, \mathrm{Cu}, \mathrm{Ag}, \mathrm{Cd}, \mathrm{Pd}$ )

(4) The degree of purification neoded depends upon the half-life and the relative sission yield of the isotope sought.

(5) Holdback oarriers are added to reduce contamination by diluting the activity mechanically oarried along.

(6) Scavenges aro useful both to mochanically adsorb normally insoluble compounds present in trace quantities and to /88r plin contaminants. Good scavonging agents, $\theta a$ sily pptd completely, are $\mathrm{Fe}(\mathrm{OH})_{3}, \mathrm{AgCl}$ from 4 N $\mathrm{HNO}_{3}$, CuS from $0.5 \underline{\mathrm{N}} \mathrm{H}^{*}$.

(7) Where chemical oonsiderations permit it is usually helpful to add carriers for all elements sought directly to the original targot soln. The aliquot taken for a particular element is then measured by the chemical yteld of that element. In the case of $\mathrm{Ag}$ this procedure is necessary because traoe quantities of this element are rapidly adsorbed by glass. 
Bxerpts from Papei on "The Pission of Thorium with Alpha Particles"

(Phys. Rev. 75 17, 1949) - Amos S. Newton

\section{Experimental Wothods}

The thorium used in the bombardment was speoial purity thorium motal produced by the group at the Atomic Research Institute at Iowa State Colloge. In a long bombardment, designated as Bombardment $A$, of 3020 pah of 39-kev helium ions (impinging energy as estimated by Dr. J. G. Hamilton) on the Crocker Laboratory cyclotron, a 3 1/2-inch diameter thorium backing plate $1 / 8$ inch thick was used. After bombardment, a rndioautograph of the disir was maje to determine the notive area." The activity was then removed by milling thin layers from the active area, using a milling set-up in which tho millings could be quantitatively colleoted. Eleven layers, varying from 1 to $3 \mathrm{mils}$ in thickness, were removed from this target so the fission product distribution and the exoitation ourve for fission could be determined. Tho milling removed about 95 percent of the total beta- and gamma-activity from the target. In addition to this, three shortor bombardments of 24-hour, 2-hour. and 4-hour duration, designated as bombardments B, C, and $\mathrm{P}$, respoctively, were obtained on thorium folls of thickess about $30 \mathrm{mg} / \mathrm{cm}^{2}$ using the interceptor set-up of the Crgoker oyolotron. In theso cases it was assumed that all of the $2-\mathrm{cm}^{2}$ area of the intercoptor reocived bombardment.

The technique used in determining the fission yields was the standard ohemical tochnique as used on the Plutonium Projeot. The bombarded sample was dissolved in oither hydrochlorio or nitrio acid, a small amount of ammonium fluosilioate being added as a catalyst. The solution was dilutod to a lonom volum and stored in Insteroid tubes insido a glass tube to prevent 1088 of activity by adsorption on glass and evaporation of the solution. Aliquots were taken for determination of eaoh desired element. In each fraotion, carrier was added for the element to bo separated, and the element chomically seperatod and decontaminated from other activities. The element was then preoipitated in a suitable form, weighed, and tho chomical yiold determinod. Tho eamples were mounted on oardboard, covered with Cellophano, and counted on the second shelf of a standard countor sot-up.

In all bombardments the 300-hr. Ba 140 was separated in order to offer a rough oheck on tho bombardment. Tho chomical mothods used in tho isolation vero modifications of thoso devoloped for the fission products by tho Plutonium Projeot.

$8 / 16 / 49$ 
Proseduros for Filtering. Dryinge Foi ghing and lounting Preolpitatos

Amos S. Nowton

Tho following prooedures arc useful in methods where a sultablo aliquot of the bombarded material is taken so that the entire preoipitato of tho elemont dosired can be coumted. This is the most aocurate procedure for dotormining chemical yields and allows maximum uso of tho original bombardod reaterial. A lnown amount of carricr is added to the aliquot of the original solution, the cloment chomically purified, and procipitated in a suitablo form.

Precipitatos which are crystallino or in othor oasily filtorod forms can be filterod on a Hirsch funnol (Coors size 00 or $000 \mathrm{~A}$ aro suitablo). A tared piece of filtor pape $13 / 16^{\prime \prime}$ diametor (a half dollar oan be used as a form for cutting filter paper) is placed in the bottom and the prooipitate transferrod to the paper and distributed crenly on tho paper with $a$ transfor pipette, boing careful not to allow the precipitato to run off the odgos of the papor. Any washing liquids can be transforred to the filtor paper in the semo manner.

Procipitates are dried by ovacuation or in the $110^{\circ}$ oron. In gonoral those precipitates which form hydrates arc driod by ovaountion using a standard proccduro for a givon precipitate whioh has beon show to cive the desired hydrato. Oven drying or longer evacuation of such procipitates should be avoidod as the composition will bo differcnt. The filter paper should be troated with the samo roagents, washod, and dricd in tho sane manor as tho final preoipitate, and woighed in order to got the tarod weight of the paper.

Since filtor paper takos up water rapidly after drying, it vill gain woight rapidly on the balanoo unless means are taken to avoid atmosphorio contact. A suitable reighing containor for these filter papers ocn bo mado by grinding the lips of two thin $50 \mathrm{~mm}$ watoh glasses flat with $200 \mathrm{mosh}$ carborundum against a flat picco of glass, being caroful to rotato prossuro points during erinding to kocp the ground area perfootly flat. Theso aro then fittod togethar to form a small chamber. Tho uptaleo of wator by a filter

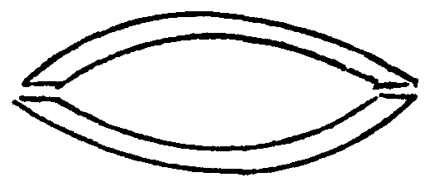

paper diso in this should not bo ovor $0.1 \mathrm{mg} / 10$ minutes whilo a voighing should be complotod vithin 2 minutos after taling the papor from tho vaouum desiccntor or oven. It is both unnoocssary and undesirablo to put the watoh glass weighing chambor in tho ovon or desiccator. If it is loft in equilibrium with tho balanco oaso at all timos woights uill bo moro roproducible. $A 180$ of coursc onc should aroid chipping the odgo of the watch elasses botween taring a filtor papor and the final woighing.

A conveniont mothod of mounting is to mount the samplo in the conter of a standard $21 / 2^{\prime \prime} \times 31 / 2^{\prime \prime}$ oardboard card. It is held in plaoo.by a piooo of $21 / 2 " \times 2^{\prime \prime}$ scotoh tape in whioh a collophanc window $13 / 16^{\prime \prime}$ diametor has beon mado, being careful to place the window difoctly over the samplo. The collophano has a thicknoss of only $\sim 2.6 \mathrm{mg} / \mathrm{om}^{2}$ compared to $\sim 9.6 \mathrm{mg} / \mathrm{cm}^{2}$ for thin Bootoh tapc and $\sim 13 \mathrm{mg} / \mathrm{cm}^{2}$ for the $2^{\text {th }}$ wido material. 
The scotch tape with cellophano windows can bo preparod ahoad of timo as follows. A picce of sootch tapo $21 / 2^{n}$ long is cut from a $2^{n}$ wido roll and plaood sticky side down on a pieoo of plate glass. The hole $13 / 16^{\prime \prime}$ diamotor is thon out with a largo cork borer (one oan bo mado from the holder for $50 \mathrm{ml}$ contrifuge conos if a suitable pioco of brass tubing cannot bo found). Tho contor holo is liftod out, the outside scotion liftod up and plaood over a piooe of collophano $13 / 8^{\prime \prime}$ diametor so that the collophano is ovon all around tho holc. Fhen ono corner of this samplo oovor is $s$ tuok to a bottlo for storage, it will koop for about 2 wocks before tho stickinoss of tho scotch tapo is lost, probably due to drying out of tho adhosivo.

Procipitatos which aro ignitod $(\mathrm{Sn}, \mathrm{Zr}$ ) aro filterod on ashloss filtor papor and ifnitod in a porcolain oruoiblo. Tho morial is then carofully transforrod to a tared paper, oarofully sprood and woighod. Tho papor is thon moistonod with a fow drops of diluto collodion in other to hold the ppt in plaoo. It is then mountod like any othor procipitato. Only that material which is mounted is woighod as the ohomical yiold dotermination is mado on the matorial which is oounted.

Examplos of Drying and Noighing wothods

Pots dricd at $110^{\circ}$

\begin{tabular}{|c|c|c|}
\hline Elemont & Ppt. & Timo (min.) drying \\
\hline$A g$ & $\mathrm{AgCl}$ & 10 \\
\hline $\mathrm{Br}$ & $A g B r$ & 10 \\
\hline I & $\mathrm{AgI}$ & 10 \\
\hline 10 & $\mathrm{Ag}_{2} \mathrm{KbO}_{4}$ & 15 \\
\hline Pd & Pd(dimothyl glyoximo) & 10 \\
\hline Cs & $\mathrm{CsClO}_{4}$ & 10 \\
\hline To & To (motal) & 10 \\
\hline Ru & Ru $(m+t a l)$ & 10 \\
\hline cd & $\mathrm{CdNRH}_{4} \mathrm{PO}_{4} \cdot \mathrm{H}_{2} \mathrm{O}$ & 10 \\
\hline
\end{tabular}

Ppts dried by cracuation

\begin{tabular}{|c|c|c|}
\hline Elomont & Ppt. & Timo Brocuation \\
\hline Sr & & (2 min., re loasc, 5 min.) \\
\hline Bo & $\mathrm{BaCl}_{2}$ & (2 min., roloase, 5 min.) \\
\hline Rare earths & R.E. ${ }_{2}\left(\mathrm{C}_{2} \mathrm{O}_{4}\right)_{3}$ & $\begin{array}{l}\text { (2 min., roloaso, } 2 \text { min. , } \\
\text { rolcase, } 3 \text { min. })\end{array}$ \\
\hline
\end{tabular}

Wigh as

$\triangle \mathrm{gCl}$

$A g B r$

AGI

$\mathrm{Ag}_{2} \mathrm{HOO}_{4}$

$\mathrm{Pd}\left(\mathrm{C}_{8} \mathrm{I}_{4} \mathrm{O}_{4} \mathrm{H}_{17}\right)$

$\mathrm{CaClO}_{4}$

To

Ru

$\mathrm{CaNH}_{4} \mathrm{PO}_{4} \cdot \mathrm{H}_{2} \mathrm{O}$

\section{Woigh as}

$\mathrm{SrC}_{2} \mathrm{O}_{4} \cdot \mathrm{H}_{2} \mathrm{O}$

$\mathrm{BaCl}_{2} \cdot \mathrm{H}_{2} \mathrm{O}$

$\mathrm{La}_{2}\left(\mathrm{C}_{2} \mathrm{O}_{4}\right)_{3} \cdot \mathrm{BH}_{2} \mathrm{O}$

$\mathrm{CO}_{2}\left(\mathrm{C}_{2} \mathrm{O}_{4}\right)_{3} \cdot 1 \mathrm{OH}_{2} \mathrm{O}$

$\mathrm{Pr}_{2}\left(\mathrm{C}_{2} \mathrm{O}_{4}\right)_{3} \cdot 9 \mathrm{H}_{2} \mathrm{O}$

$\mathrm{Y}_{2}\left(\mathrm{C}_{2} \mathrm{O}_{4}\right)_{3} \cdot 7 \mathrm{~B}_{2} \mathrm{O}$

$\mathrm{Bu}_{2}\left(\mathrm{C}_{2} \mathrm{O}_{4}\right)_{3} \cdot 10 \mathrm{H}_{2} \mathrm{O}$

\section{$8 / 16 / 49$}


CHEMICAL SEPARAT IONS

Element separated: Sodium Prooodure by: D. B. Stowart

Targot matorial: Alúminum alloy

$95 \% \mathrm{Al}, 2.25 \% \mathrm{H}, 0.25 \% \mathrm{Cr}(+\mathrm{Fo} \& \mathrm{Cu})$

Timo for sop'ni $\sim 8 \mathrm{hrs}$.

Typo of bbdt: $184^{\circ}$ douterons

Equipment roquirod: Contrifugo cono, boaker

Yield: $\sim 60 \%$

Dogree of purification: $10^{4}$ from Al, others unkmown

Prooeduro:

(1) Dissolvo aluminum in 6 N HCl. Add $50 \mathrm{mg}$ Fa and $10-80 \mathrm{ng}$ Cu carriers.

(2) Procipitato $\mathrm{Al}(\mathrm{OH})_{3}$ with slight exoess of $\mathrm{WH}_{4} \mathrm{CH}$. Contrifuge, pour off supormatant. Dissolvo first preolpitato in BCI and repeat, adding the 2nd supermatant to the original.

(3) Saturato solution with $H_{S} S$ to precipitato Cus and romaining Al as $\mathrm{Al}_{2} \mathrm{~S}_{3}$. Filter or contrifugo.

(4) Aoldify filtrato with $\mathrm{HCl}_{2}$ or $\mathrm{ENO}_{3}$ and ovepora to to drymose. $\mathrm{MH}_{4}{ }^{+}$salts can be quiokly destroyod by boiling with a $1: 4 \mathrm{HCl}-\mathrm{FHO}_{3}$ mixture. Residuo is mixture of $\mathrm{FaCl}$ and $\mathrm{Fa}_{2} \mathrm{SO}_{4}$. 
Flement separated: Mpesium

Target material: Aluminum alloy

$95 \% \mathrm{Al}, 2.25 \% \mathrm{LF}, 0.25 \% \mathrm{Cr}\left(+\mathrm{Fo}_{\mathrm{O}} \mathrm{Cu}\right)$

Typo of bbdt: 184 deuterons

Yield: $90-200 \%$

Degree of purification: $10^{4}$ from $A I$ and $C u$

Prooedure:

(1) Dis 8017o aluminum in minimum dilute HCl. Add 25 mg is and 5 me Cu carriers. Dilute to about $0.3 \mathrm{~N}$ - HCl.

(2) Saturate solution with $\mathrm{H}_{2} \mathrm{~S}$ to procipitate CuS. Filtor. Wash proolpitato with $0.1 \mathrm{~N}-{ }^{2} \mathrm{HCl}$ containing a little $\mathrm{H}_{2} \mathrm{~S}$

(3) Boil filtrate to expel H,S. Volumo of solin should bo groator than $50 \mathrm{ml}$ (or to givo $\sim 1 \mathrm{mg} 1 \mathrm{~g} / 2 \mathrm{ml}$ solution). Add $2-5 \mathrm{~g}$ tartaric aoid, or slight ex0ess over tho amount required to complox tho aluminum. Houtralize with $\mathrm{NH}{ }_{4}$ OIf and male juat aoid with 1 drop of BCl. Tarm slightly.

(4) Add $2 \mathrm{~g}$ (NH $\left.{ }_{4}\right)_{2} \mathrm{HPO}_{4} / 100 \mathrm{ml}$ solution and $\mathrm{HH}_{4} \mathrm{OH}$ dropwise with

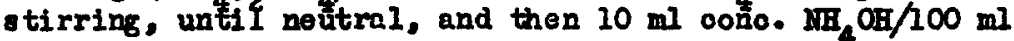
solution. Let stand $1 \mathrm{hr}$. or moro to allow formation of $\mathrm{Ng}\left(\mathrm{NH}_{4}\right)_{2} \mathrm{PO}_{4}$ 
Elomont separatod: Phosphorous

Targot material: $C_{\mathfrak{u}}$

Typo of bbdt: $\$ 11$ 18:" and $60^{\prime \prime}$

Yiold: $60 \%$
Prooodure by: Batzel

Timo for $80 \mathrm{pin}$ : 2 hrs.

Equipmont roquirod: Standard

Dogrco of purification: Factor of 100 from all activitics prosont oxcopt vanadium. Probably faotor of 50 from $V$.

Proceduro:

(1) Dissolvo targot in Erro $3^{\circ}$ Add $5 \mathrm{mg} \mathrm{P}_{\text {as }} \mathrm{PO}_{4}^{-3}$ and noutralizo most of froo aoid with $\mathrm{NH}_{4} \mathrm{OH}$.

(2) Nako $1 \mathrm{~N}$ in $\mathrm{EHO}_{3}$ and add ammonium molybdato to tho warm solution $\left(50^{\circ} \mathrm{C}\right)^{-}$(add $6 \mathrm{il}$ of molybdato for overy $1 \mathrm{mg}$ of $\mathrm{P}$ ).

(3) Allar to sottle for 15 minutos. Contrifugo and wash with $1 \% \mathrm{HMO}_{3}$.

(4) Dissolvo with $\mathrm{MH}_{4}$ OH oitrato solution and add $\mathrm{HCl}$ until tho ppt that forms dissolros with difficulty. A.dd 5 mg vanadium holdback oarrior.

(5) Bubble $\mathrm{SO}_{2}$ through tho solution to roduce $\mathrm{VO}_{3}^{-}$to $\mathrm{Vo}^{++}$. Add $2 \mathrm{ml}$ of cold $\mathrm{IfCl}_{2}$ mixturo - allow to sottlo 5 minutos and add cono NIH OH until solution is $1 / 1$ of original volumo. Nllow to sottlo fol 15 min. Contrifuge and wash procipitato with $1: 4 \mathrm{MH}_{4} \mathrm{OH}_{8} \mathrm{H}_{2} \mathrm{O}$.

(6) Add $5 \mathrm{mg}$ vanadium holdback carrior and repoat atop (5).

(7) Dissolve ppt in $1 \mathrm{~N}_{\mathrm{HNO}} \mathrm{H}^{\circ}$

(8) Repont (2) and (3).

(9) Weigh as ammonium phosphomolybdato.

Rof. Soott's Standard Hothods of Chomioal 'Analysis, Vol. I, pago 694. I. H. Kolthoff \& Sandoll, E.B., Toxtbook of Quantitativo Inorganio Analysis, page 368 .

\section{Remarks:}

Vanadium $q 0$ ppts with phosphorus if it is in $v^{+5}$ stato. It should bo roduoed to $\mathrm{vo}^{+}$atato \& the oycle ropeatod two times in ordor to romovo vanadium o omplotoly.

\section{$8 / 21 / 19$}


Element separated: Chlorine

Target material: Copper

Type of bbdt: A1I -

Yield: $60 \%$

Degree of purification: $10^{3}$
Procedure by: Batzel

Time for sop'n: 30 minutos

Equipment requireds standard

Prooedure:

(1) Dissolvo the copper in concentrated $\mathrm{HrO}_{3}$ containing 5 ing of chlorine carrier (1-2 ml concentrated $\mathrm{HllO}_{3}$ for $0.1-0.3$ grams coppor foil)

(2) Distill the chlorine into a contrifuge tube containing 2 co of water, 2-3 drops of conoentrated $\mathrm{EHO}_{3}$, and sufficient $\mathrm{ABHO}_{3}$ to preoipitate the ohlorine as AgCl.

(3) Hoat almost to boiling, contrifuge the procipitate and wash with 3 oc of $2 \mathrm{~N} \mathrm{HNO}_{3}$.

(4) Dissolve the AgCl in 3 co of $5 \mathrm{~N} \mathrm{MH}_{4}$ OH and add a drop of holdback carriers from standard $10 \mathrm{mg} / \mathrm{ml}$ solns, for $\mathrm{Cu}, \mathrm{N1}, \mathrm{Co}, \mathrm{Zn}, \mathrm{Fo}$ (add as nitrates or sulfates) and then add 2 drops of 0.5 N KI.

(5) Contrifuge and wash the preoipitate with $2 \mathrm{cc}$ of $5 \mathrm{~N} \mathrm{NH}_{4} \mathrm{OH}$. Add tho wash to the supernato and add excess $\mathrm{AgNO}_{3}$ to preoipitate tho excoss lodide (5 drops of 0.5 II $\mathrm{AgNO}_{3}$ ).

(6) Centrifuge and wash as bofore saving the supornate and wash.

(7) Nake acid with $\mathrm{BrO}_{3}$ to preoipitate the $\mathrm{AgCl}$, oentrifuge, and wash tho procipitate twioo with $3 \mathrm{ml}$ portions of $2 \mathrm{~N} \mathrm{HIO}_{3}$. The precipita to can be plated directly or dis8olved in $\mathrm{iH}_{4}$ OH and an aliquot taken.

Remarks: If an appreciable cmount of coppor is to be dissolved the heat of reaction may drive the ohlorine carrier into the reoeiving vessel before the copper is completely dissolved. If this occurs add $2.5 \mathrm{mg}$ of ohlorine carrier as ohloride to the wator in the receiver and after the copper is in solution add an additional $2.5 \mathrm{mg}$ to the copper solution and distil as stated abovc. In oase bromine is present it may be removed by making the solution $0.5 \mathrm{H}$ in $\mathrm{HNO}_{\mathrm{g}}$ before precipitation, adding 5 me of $\mathrm{Br}^{-}$ oarrier, 0.25 grams of ammonium persulfate and boiling, thus oxidieing the $\mathrm{Br}$ to $\mathrm{Br}$, and volatilizing. The solution should then be reduced rith hydrazine and the chlorine precipitated as AgCl.

$7 / 12 / 49$

P-18-58 


\section{CHEMICAL SEPARATIONS}

Element separated: Potassium

Target material: LiCl

Typo of bbdt: alpha 20-60 Mev
Procedure by: Brooks

Timo for sepin: $1 \mathrm{hr}$.

Equipmont required: $\sin 11$ centrifuge tubes,72\% perchlorio acid

Yield: Yuantitative is possible

Degree of purifloation: Radio ohemically pure possibly.

Advantaces: Simplicity and speed.

Frocedure:

(1) Dissolve LiCl in about 3 oo water add $\mathrm{KCl}$ carrier ( $20 \mathrm{mg}$ )

(2) Add 5 co of $72 \% \mathrm{HClO}_{4}$ and cool in ioe.

(3) Cantrifugo.

(4) The $\mathrm{KClO}_{4}$ may be reorystallized as many times as desired by heating it to $\sim 90^{\circ} \mathrm{C}$ with 1 os of $72 \% \mathrm{HClO}_{4}$ and than cooling in 100.

Eemarko: 4 recrystallizations can be made in 1 hour of chemistry. About $1 / 2 \%$ is lost per recrystallization by doing it this fast. A trace of $\mathrm{P}^{32}$ sometimes was not removed by this chemistry. $\mathrm{IJI}_{4}^{+}$sait: interfere. Separation from $\mathrm{Na}$ is good. No $\mathrm{Rb}$ or $\mathrm{Cs}$ intamizetion was found.

$6 / 16 / 49$ 
CEEMTCAL SEPARATIONS

Element separated: Potassium

Target material: IICl

Type of bbdt: alpha 20-60 uev

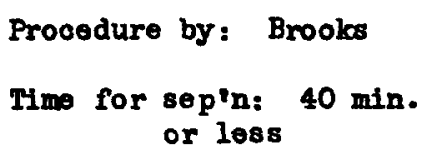
yellow s reagent

Yield: $50 \%$ or more depending on speed required.

Degree of purification: Radiochemically pure is possible.

Advantages, Fast and simplo

Prooedure:

(I) Dissolve LICl in 5 oc of $\mathrm{H}_{2} \mathrm{O}$

(2) Add $10 \mathrm{cc}$ of Napthol-yellow-S (5\% solution) 0001 and contrifuge.

(3) Reorystallize from about 5 co of NYS $5 \%$ in ice.

(4) The ppt can be dissolred quiokly in water or weak acid.

(5) Scavenge with $\mathrm{Fe}(\mathrm{OH})_{3}$.

Remarks: $\mathrm{NH}_{4}^{+}$salts interferé

$6 / 16 / 49$ 


\section{CHE:IICAL SEPARA TIONS}

Element separated: Calcium

Procedure by: Goeckermann

Target material: ज1g Bi motal

Time for sep'n: Few hrs.

Type of bbdt: 184" bbdt all particles

Equipmont required: Centrifuge

Yicld: U $20 \%$

Degree of purification: $30 \mathrm{o} / \mathrm{m}$ of Ca separated from $\mathrm{Va}$ millicurie of fission and spallation products.

Advantages: Sejarates Ca from all other elements.

Procedure:

(1) To allquot of $\mathrm{HNO}_{3}$ sol in of $\mathrm{BI}$, add $20 \mathrm{mg} \mathrm{Ca}$ and $10 \mathrm{mg}$ cach of $\mathrm{Ru}, \mathrm{Cb}, \mathrm{Fe}, \& \mathrm{La}{ }^{3}$ Kake $0.5 \mathrm{~N}$ in $\mathrm{HCl}$ \& $\mathrm{ppt}$ with $\mathrm{H}_{2} \mathrm{~S}$.

(2) Add $10 \mathrm{mg} \mathrm{Ru} \& \mathrm{Bi}$ to supn \& repeat $\mathrm{H}_{2} \mathrm{~S}$ pptn.

(3) Boil out $\mathrm{H}_{2} \mathrm{~S}$ \& ppt with $\mathrm{NH}_{3}$.

(4) Add $10 \mathrm{mg} \mathrm{Fe}$ \& $\mathrm{Y}$ to supn \& repoat $\mathrm{MH}_{3}$ pptn.

(5) Boil down to $45 \mathrm{ml}$, add $10 \mathrm{mg}$ Ba \& $\mathrm{Sr}$, \& ppt with cold fuming HINO $_{3}$.

(6) Add more $\mathrm{Sr} \& \mathrm{Ba}$ to supn \& repeat pptn three times.

(7) Add Sr alono \& repeat two timos more.

(8) Boil down to $u 5 \mathrm{ml}$, add $5 \mathrm{ml}$ sat $\left(\mathrm{NH}_{4}\right)_{2} \mathrm{C}_{2} \mathrm{O}_{4}$, a make basio with $\mathrm{NH}_{3} \cdot$

(9) Dissolvo $\mathrm{CaC}_{2} \mathrm{O}_{4}$ ppt in HNO $\mathrm{H}_{3}$, destroy $\mathrm{C}_{2} \mathrm{O}_{4}=$ with $\mathrm{KClO}_{3}$, \& make basic with $\mathrm{NH}_{3} \cdot \mathrm{Add}^{4} \mathrm{Fe}$, La, \& $\mathrm{Y}_{3}^{3}$ contrifuge?

(10) Add more Fe, La, \& Y to supn \& repeat pptn., oentrifuge.

(11) Repeat step (5)

(12) Boil supn down to $n 5 \mathrm{ml}$, make basio with $\mathrm{NH}_{3}$, heat, add $5 \mathrm{ml}$ sat $\left(\mathrm{NH}_{4}\right)_{2} \mathrm{C}_{2} \mathrm{O}$ lowly. stir $2 \mathrm{~min}$. filter, wash three times with $5 \mathrm{ml}$ $\mathrm{H}_{2} 0$; three tires with $5 \mathrm{ml} 95 \% \mathrm{EtOH}$, three times with $5 \mathrm{ml}$ ether. Diry in vacuum dessioator -- 2 min. evac, release, 5 min evac. Weigh as $\mathrm{CaC}_{2} \mathrm{O}_{4}$ (32 mg per $10 \mathrm{mg} \mathrm{Ca}$ ).

$6 / 27 / 49$

P-18-25 


\section{CHEMICAL SRPARATIONS}

Element separated: Calcium

Target material: Coppor

Type of bbdt: All $60^{\prime \prime}$ and $184^{n}$

Y10 1d: $95 \%$

Degree of purifioation: $10^{3}$

Advantages: Pure fraction with good yield.

Procedure:

(1) Dissolve the copper in the minimum amount of concentrated $\mathrm{HWO}_{3}$. Add few mg oarriers ( $\mathrm{Zn}$ and below) including $\mathrm{Ca}$ and make the solution amonioal with carbonate free $\mathrm{MH}_{4} \mathrm{OH}$.

(2) Preoipitate the sulfides with $\mathrm{H}_{2} \mathrm{~S}$. Add holdback carriers and scavenge with another sulfide precipitation. Repeat.

(3) Boil to remove the $\mathrm{H}_{2} \mathrm{~S}$ and make acid with oxalic acid. Add $5 \mathrm{ml}$ of $4 \%\left(\mathrm{NH}_{4}\right)_{2} \mathrm{C}_{2} \mathrm{O}_{4}$ and al low prooipitate to settle for 10 minutos in a steam bath.

(4) Tash the precipitate with water containing oxalic acid and ammonium oxnlate.

(5) Dissolve the precipitate in $6 \mathrm{~N} \mathrm{ENO}_{3}$ and add a crystal of $\mathrm{KClO}_{3}$ to remove oxalate ions.

(6) Male ammonioal and soavenge 2 times with $\mathrm{Fr}(\mathrm{OH})_{3}$.

(7) Inko acid with oxalic acid and add $3 \mathrm{co}$ of $4 \%\left(\mathrm{NH}_{4}\right)_{2} \mathrm{C}_{2} \mathrm{O}_{4}$. Allow to settle for 10 minutes on a steam bath.

(8) Centrifuge, wash, filter, and dry at $100^{\circ} \mathrm{C}$. The precipitate is weighed as $\mathrm{CaC}_{2} \mathrm{O}_{4} \cdot \mathrm{H}_{2} \mathrm{O}$.

Remariss :

(1) Seo Soott's Standard Lothods of Chemical Analysis, Page 210-211, Vo1. I, Fifth Editior, 1939. 
Element separated: Calcium

Target material: Copper (up to $10 \mathrm{~g}$ )

Typo of bbdt: Noutrons 184"
Prooedure by: Stowart-Softicy

Timo for sep'ns $4 \mathrm{hrs}$.

Bquipment requi rod :

$200 \mathrm{ml}$ stainless steol boaker

Pt stirror eleotrode

D. C. source

$200 \mathrm{ml}$ oentrifuge cono

Yiold: $60-80 \%$

Dogree of purification: $10^{6}$ from Cu

Proceduro:

(1) Dissolvo $\mathrm{Cu}_{\mathrm{u}}$ in minimum diluto $\mathrm{HJO}_{3}$ in a stainless stool beaker, add $10 \mathrm{mg}$ Ca carrier as nitrato and 2-3 drops of conc. $\mathrm{H}_{2} \mathrm{SO}_{4}$. Dilute to $200-150 \mathrm{ml}$.

(2) Electrodeposit copper at 2-3 volts using the beaker as the cathodo and a rotating platinum anode. Kaop the stainless stecl bcakor in an ice bath during the oloctrolysis.

(3) Thon solution is water-white remove the anodo and transfer the solution quiokly to a $200 \mathrm{ml}$ contrifugo cone. Noutralies with $\mathrm{MH}_{4}$ OH and make just acid with $\mathrm{HNO}_{3}$. Tharm in a hot water bath.

(4) Add $20 \mathrm{~g}$ crystalline ammonium oxalato and stir solution for 30 minutes, !o eping it warm. Transfor to an $i 00$ bath and continuo stirring for another 30 minutes.

(5) Let settle, and finally centrifuge. Pipet off the supernatant. Wash CaC $\mathrm{O}_{4}$ with hot water containing a little $\left(\mathrm{NH}_{4}\right)_{2} \mathrm{C}_{2} \mathrm{O}_{4}$ until wash solution is oolorless. 


\section{CHERTICAL SEPARATIOMS}

Element soparated: Scandium

Target material: Copper

Type of bbdt: All $60^{\prime \prime}$ and $184^{\prime \prime}$

Yield: $60 \%$

Degreo of purifications Daotor of 100 from othor activitios prosont.
Procedure by: Batzel

Time for sep'n: $11 / 2 \mathrm{hr}$.

Equipmont required: Standa rd

Procodure:

(1) Dissolve coppor in minimum amount of $\mathrm{BNO}_{3}$. Boil to romove axcess. Add $5 \mathrm{mg}$ of So and other carriers. Adjust to $1 \mathrm{~N}$ in BCl and treat with $\mathrm{H}_{2} \mathrm{~S}$ (CuS out).

(2) Boil to remove $\mathrm{H}_{2} \mathrm{~S}$, add $\mathrm{HH}_{4} \mathrm{OH}$ and $\mathrm{MH}_{4} \mathrm{Cl}$ till ammonical. Centrifuge and wash ppt with hot $\mathrm{MH}_{4}$ CI solution.

(3) Dissolve ppt in $\mathrm{HCl}$ and make $6 \mathrm{~N}$ in $\mathrm{BCl}$. Extract $\mathrm{Fo} 3$ times with equal volume othyl acotato. Add 3 ig of $\mathrm{Fe}$ oarrier and again extract Fo.

(4) Make the $p H$ of the solution 2.0 and extract with equal volumo ITA (5 ml of $0.5 \mathrm{M}$ in benzene.) Shake for 10 minutos. Tash TTA layer with three $4 \mathrm{ml}$ portions of water.

(5) Extract into I I BCI with two $3 \mathrm{ml}$ portions.

(6) Ppt the So as hydroxide with MOH. Mash with $\mathrm{H}_{2} \mathrm{O}$. Repeat tho extraotion with fresh TTA.

(7) The soandium oan be weighed as $\mathrm{So}_{2} \mathrm{O}_{3}$ after preoipitation as $\mathrm{So}(\mathrm{OH})_{3}$ and ignition. 
Element separatod: Vanadium

Target meterial: Copper foll ( 1 gm.)

Type of bbdt: 184-inch, all.
Procedure by: Batzel

Tims for sop'n; $\sim 2$ hours

Equipment requirod: Standard

Yield: Fair (undoterminod)

Degroe of purification: Ondotermined (only probably impuritios, Cr and P)

Procedure:

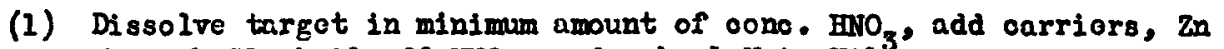
through $\mathrm{Cl}$, boil off $\mathrm{EHO}_{3}$, and mako $1 \mathrm{~N}$ in $\mathrm{HCl}$.

(2) Add $\mathrm{H}_{2} \mathrm{~S}$, contrifuge off ooppor. Fesh oopper with $1 \mathrm{~N} \mathrm{HCl}$ and resaturâte with $\mathrm{H}_{2} \mathrm{~S}$. Add wash to super nato.

(3) Boil down to removo $\mathrm{H}_{2} \mathrm{~S}$, to $6 \mathrm{ml}$. add oono. Hno and boil down almost to dryness, and make $\mathrm{V}^{\mathrm{O}} \mathrm{l}$. to $5 \mathrm{ml}$. with conc. $\mathrm{HfO}_{3}$; oautiously add $\mathrm{KClO}_{3}$ and boil for one minute.

(4) Contrifugo off $\mathrm{MnO}_{2}$, "Wsh $\mathrm{MnO}_{2}$ with $6 \mathrm{~N} \mathrm{HNO}_{3}$, and add rash to supornate.

(5) Boil down to remore $\mathrm{HNO}_{3}$ and $\mathrm{HCl}$, and mako $1 \mathrm{~N}$ in $\mathrm{BrO}_{3} \cdot$ Cool to $5-10^{\circ} \mathrm{C}$, and add an equâl volume of diethyl other. Aâd 5 drops of $30 \% \mathrm{H}_{2} \mathrm{O}_{2}$ and immediately stir vigorously to extract chromium. Draw off other layer, and wash water layer with ono-half volume of ethor, stirring vigorously to extract any chromium left. Draw off ether layer and add to original ethor layer.

(6) Almost neutralize the wator laycr with NaOH and pour into $10 \mathrm{ml}$ of a hot solution of $1 \mathrm{~N}$ KOH. (A small amount of $\mathrm{Fe}$. mast be present.) contrifugo off hydroxides of $\mathrm{HI}, \mathrm{C}, \mathrm{Fe}, \mathrm{TI}, \mathrm{So}$, and Ca. Wash prooipitato with $4 \mathrm{ml}$. of hot $1 \mathrm{I}$ FaOH. Add wash to supernate.

(7) Soavenge by adding 1 drop of $\mathrm{Fe}^{+++}$oarrior $(10 \mathrm{mg} \cdot / \mathrm{ml} \cdot)$ and $500 \lambda \mathrm{Tl}^{+4}$ (10 mg./ml.) to tho hot solution. Contrifluge and wash preoipitate with $4 \mathrm{ml}$. of hot $1 \mathrm{~N} \mathrm{NaOH.}$

(8) Bo11 down to $6 \mathrm{ml}$. Nake slightly acid with ooetio aoid and add $5 \mathrm{ml}$. of $10 \% \mathrm{~Pb}\left(\mathrm{AO}_{2}\right)_{2}$. Centrifugo off $\mathrm{Pb}\left(\mathrm{VO}_{3}\right)_{2}$, and wash with slightly acidic, dilute $\mathrm{Pb}(\mathrm{AC})_{2}$. Add wash to supernate (containing

(9) Make 2 II with INO , precipitate $\mathrm{Pb}$ as the sulfide by adding $\mathrm{H}_{2} \mathrm{~S}$. Contrifüge and wash preolpitato with 2 N $\mathrm{HNO}_{3}$. Add wash to supernoto. Boil to removo $\mathrm{H}_{2} \mathrm{~S}$.

(10) Toutralizo with NaOH, mako slightly ac:d with HAc and reprocipitato vanadium as lead ranadate. Toigh.

Romarks: Roforence: Sootts Standard Lethods of Chomical Analysis, p. 1036. $8 / 29 / 49$ 
Element separated: Chromium

Target material: As

Type of bbdt: $190 \mathrm{MeV} \mathrm{D}^{+}$
Procedure by: H. Hopleins, Jr.

Time for sep'n: $3 / 4 \mathrm{hr}$.

Equipment required: standard

Yield: $60 \%$

Dogree of purification: unfactor of 50 from other activities.

Procedure:

(1) Dissolve As in $\mathrm{HHO}_{3}{ }^{\circ}$ Add $10 \mathrm{mg} \mathrm{Cr}$ carrier and evaporate to $\mathrm{M}_{2} \mathrm{cos}$

(2) Add 100 fuming $\mathrm{HMO}_{3}$ and several orystals $\mathrm{KClO}_{3}$. B oil several minutes, adding more $\mathrm{KClO}_{3}$.

(3) Cool, add $\mathrm{KOH}$ and water to about 25 co of $\mathrm{l} N \mathrm{~A}^{+}$. Chill in ico salt bath to near freozing, add 10 co oold ether. Add $1 \mathrm{dp} \mathrm{H}_{2} \mathrm{O}_{2}$ and extraot deep blue oolor into ether.

(4) Add a second portion of other and $\mathrm{H}_{2} \mathrm{O}_{2}$. Whash the cold ether layers with four quarter volumes of water containing 1 drop oonc. $\mathrm{HMO}_{3}$.

(5) Extract ohromate out with dilute $\mathrm{EJH}$, add other holdback carriers and Hho to slightily acid.

(6) Add Ba dropwise to procipitate $\mathrm{BaCrO}_{4}$.

Remarks: Procedure should be practiced so success of the oxidation and oxtraction can be recognized. 


\section{CHEMICÁL SLPARATIONS}

Element separated: Chromium

Procedure by: Goeckerman

Target material: approx. 1 g Bi motal

Timo for sep'n: 1-2 hrs.

Type of bbdt: 184" all particles

Equipment required: Centrifuge, oones, $110^{\circ}$ oren.

Yiold: Approx. 50\%

Degree of purifloation: Fow c/m separatod from several million counts of fission and spallation products.

Advantages: Fair yield of pure $\mathrm{Cr}$.

Prooedure :

(1) To aliquot of $\mathrm{ENO}_{3}$ soln +3 target add $10 \mathrm{mg}$ Cr as $\mathrm{Cr}_{2} \mathrm{O}_{7}=$ Add HCl \& $\mathrm{HCOOH}$ to reduce to $\mathrm{Cr}^{+3}$. Ppt $\mathrm{Bi}_{2} \mathrm{~S}_{3} \& \mathrm{Sb}_{2} \mathrm{~S}_{3}$ scavenger from 1 N HCl soln.

(2) Ppt $\mathrm{Cr}(\mathrm{OH})_{3}$ with $\mathrm{K}_{2} \mathrm{CO}_{3}+\mathrm{H}_{2} \mathrm{~S}$, by long boiling.

(3) Oxidize in $10 \mathrm{ml} 0.5 \mathrm{II} \mathrm{HaOH}$ with $\mathrm{H}_{2} \mathrm{O}_{2}$, scarengo with $\mathrm{Fo}(\mathrm{OH})_{3}$, \& destroy $\mathrm{H}_{2} \mathrm{O}_{2}$.

(4) Sike slightly aoid with $\mathrm{S}_{2} \mathrm{H}_{2} \mathrm{SO}_{4}$ \& wash with ether.

(5) Add $\mathrm{H}_{2} \mathrm{O}_{2}$ \& extraot $\mathrm{H}_{3} \mathrm{CrO}_{8}$ into about equal volume of ether.

(6) Re-oxidize \& re-extract aqueous phase.

(7) Evaporate ether over $\mathrm{H}_{2} \mathrm{O}$ \& repeat $\mathrm{H}_{3} \mathrm{CrO}_{8}$ extrn.

(8) Evap ether over $\mathrm{H}_{2} \mathrm{O}$, axidise with $\mathrm{H}_{2} \mathrm{O}_{2}$ in alkal ine soln, soarenge with $\mathrm{Fe}(\mathrm{OH})_{3}$.

(9) Aoldify with $6 \mathrm{~N} \mathrm{HWO}$, add $1 \mathrm{ml} 6 \mathrm{~N} \mathrm{HAc} \& 2 \mathrm{ml} 6 \mathrm{~N} \mathrm{NH} A 0$, heat, add several ml $50 \mathrm{~g} 7 \mathrm{Ba}$ soln. Filter, wash with hot $\mathrm{H}_{2} \mathrm{O}^{4}$ \& Etorr, dry $10 \mathrm{~min}$. at $110 \mathrm{C}$. Toigh as $\mathrm{BaCrO}_{4}$ ( $48.7 \mathrm{mg}$ per $10^{2} \mathrm{mg} \mathrm{Cr}$ ).

Remarks: $\mathrm{H}_{3} \mathrm{CrO}_{8}$ extrn tricky, easy to lose $\mathrm{Cr}$ by reduction before extraction.

$6 / 27 / 49$

P-18-19 


\section{CHEUTCAL SEPARATIOMS}

Element separated: Chromium

Procedure by: Batzel

Target material: Copper

Time for sep'n; 40 minutes

Type of bbdt: All 184" and 60"

Equipment required: standard

Yield: $50 \%$

Degree of purification: $10^{2}-10^{3}$

Advantages: Very specifio - no interforing lons.

Procedure:

(1) Dissolve the oopper in the minimum amount of concentrated HRO $_{3}$. Boil almost to drymess, add carriers ( $Z_{n}$ and below) and make $I$ N in $\mathrm{ACl}$.

(2) Preolpitate the oopper as sulfide, make the supernate alkaline with $\mathrm{NH}_{4} \mathrm{OH}$ and preol pitate the sulfides including $\mathrm{Cr}$ with $\mathrm{H}_{2} \mathrm{~S}$.

(3) The in is usually removed at this point (seo procodure for $\mathrm{Ma}(25-5)$. Heutraliee the $\mathrm{HWO}_{3}$ and make 1 II in $\mathrm{HrO}_{3}$.

(4) Cool in an ice bath to $5^{\circ} \mathrm{C}$ and add 0.5 oc of $30 \% \mathrm{H}_{2} \mathrm{O}_{2}$. Extract the blue peroxyohromio acid with othyl other. (two 4 mi portions).

(5) Fash the ether layer with three $1 \mathrm{ml}$ portions of water aoidified with a drop of $\mathrm{BrO}_{3}$.

(6) Extract the ohromium from the other layer with 3 co of distilled water made distinctly alloaline with $\mathrm{NB}_{4} \mathrm{OH}$.

(7) The Cr may be preoipitated and weighod as $\mathrm{BaCrO}_{4}$.

Remarks : (2) The In is usual ly removg (step 3 ) so that an estimate can be 51 .
made of the amount of $\mathrm{Cr}_{\mathbf{r}}$ formod by decay of the 42 minute 5 . 


\section{CHEMTCAL SEPA PAT IONS}

Elomont separated: Chromium

Prooedure by: D. B. Stowart

Target material: Aluminum alloy

$95 \% \mathrm{Al}, 2.25 \% \mathrm{KH}, 0.25 \% \mathrm{Cr}(+\mathrm{Fo} \& \mathrm{Cu})$

Tire for sep'n: $\sim_{1} \mathrm{hr}$.

Type of bbdt: 184" deuterons

Equipment requirod: Standard

Yiold: $60-80 \%$

Dogreo of purification: $10^{4}$ from $\$ 1$, others unknown

Procodure:

(1) Dissolvo aluminum in 6 I HCl. Ndd $25-50 \mathrm{mg}$ Cr oarrior, $5 \mathrm{mg}$ cu carrior.

(2) Oxidizo $\mathrm{Cr}$ to dichromate by bolling with $1 \mathrm{~g}$ ammonium persulfato and 2-3 drops of $2 \% \mathrm{AgHO}_{3}$ solution.

(3) Removo Al, 化, Fo by precipitation with exoess $\mathrm{NH}_{4} \mathrm{OH}$. Centrifuge, \& decant supernatant. Dissolvo prooipitato in HCI and repeat to get out more of the $\mathrm{Cr}$ whioh can be ocoludod.

(4) Aoidify the combinod supornatants with HCl (0.1-0.3 N aoid). Saturato with $\mathrm{H}_{2} \mathrm{~S}$ to procipita to $\mathrm{CuS}$ and reduce ohromium to $\mathrm{Cr}^{+3}$. Contrifugo or filter off the CuS.

(5) Boil filtrate to expcl $\mathrm{H}_{2} \mathrm{~S}$ and reduce volume as far as possible. Make solution basio with $\mathrm{HH}_{4} \mathrm{OH}$. A golatinous groen procipitate of $\mathrm{Cr}(\mathrm{OH})_{3}$ forms on boiling off tho oxooss $\mathrm{MH}_{3}$.

$8 / 24 / 49$

$P-18-268$ 
Element separated: langanese

Target material: $\mathrm{Cr}, \mathrm{Hin}, \mathrm{Fo}, \mathrm{Co}, \mathrm{Mi}, \mathrm{Cu}$, 2n, Ga, Ge, As, Se, Br, $\mathrm{Rb}$, or $\mathrm{Sr}$.

Type of bbdt: $190 \mathrm{Kev}$ deuterons, $30 \mathrm{~min}$.
Prooedure by: H. C. Orr

Timo for sep'n: 2 hrs.

Bquipment required, sintered glass filters $100 \mathrm{ml}$ beakers $50 \mathrm{ml}$ vol. flask

Yield: 60-80\%

Degree of purification: Adequate for determining $\mathrm{ln}^{52}$ and $\mathrm{m}^{56}$ yields. Rocyoling should $g$ ive increased purification.

Advantages: Simplioity.

Procedure:

(1) Target is dissolrad in $30 \mathrm{ml}$ oonc. $\mathrm{HNO}_{3}$. (HCl used far $\mathrm{Cr}$ ).

(2) 25 to 50 mg of standardised carrier is added, i.e., a measured vol. of solution of lenow ooncentration.

(3) Several mg of hold-back carriors added, all elements exoept in from $8+1$ to $z-12$ ( 3 = target at. no.).

(4) Boil to expel oxides of nitrogen.

(5) Solid $\mathrm{KClO}_{3}$ is added SLOFLY Thit after adding each increment for the evolution of $\mathrm{ClO}_{2}$, eto. Continue until ppt'n of $\mathrm{HnO}_{2}$ is complete. Boil continuousisy.

(6) Filter through a medium sintered glass filter on which a layer of "Superoel" has been laid down. Wash with conc. $\mathrm{HIO}_{3}$.

(7) $\mathrm{HnO}_{2}$ is dissolved direotly on the filter by conc. $\mathrm{HnO}_{3}$ to whioh $30 \%{ }^{2} \mathrm{H}_{2} \mathrm{O}_{2}$ is added dropwise. Solution may be drawn through the filtar Into clean filtering flask and transforred to a cloan $100 \mathrm{ml}$ beaker.

(8) The oarriers of step (3) are again added.

(9). The solution is boiled to decompose $\mathrm{H}_{2} \mathrm{O}_{2}$. Cono. $\mathrm{HMO}_{3}$ is added to restore vol. to $30 \mathrm{ml}$.

(10) Repeat steps (5) through (9) two or more times (see remarks, following).

(11) Repoat s tops (5), (6), and (7) 
(12) Boil to decompose $\mathrm{H}_{2} \mathrm{O}_{2}$; i.e., solution becomes colorloss and vol. is less than $50 \mathrm{ml}$.

(13) Transfer to $50 \mathrm{ml}$ vol. flask and dilute to mark. Samples of 25, and 100 should be suitable for oounting $(2.59 \mathrm{hrs}$ ) de.oaying into $\operatorname{Mn}^{52}$ ( 6 days) half-life.

Remarks: The repetition of steps indicated in (10) should give increased purification. The whole procodure should include not less than three precipitations of $\mathrm{NmO}_{2}$.

In cases where step (9) preceded step (8) good separation was not always achieved, presumably bocause the aotive impurity was not in the same oxidation state as the added carrier at the beginning of $\mathrm{maO}_{2}$ precipitation.

Presenoe of sulfate is to be avoided because soluble oulfate complexes of $\mathrm{kn}$ (III) render preclpitation incomplete.

According to Soott (Std. Meth. Chem. Anal.) oxides of W, Si, Cb, and Ta are also ppt'd by $\mathrm{KClO}_{4}$ as in this procedure.

P-18-8 
For determining chemical yields in a series of separations of lin aotivity from other elements the following procedure is partioularly easy and of an aocuracy comparable with other methods.

Assuming that $2.0 \mathrm{ml}$ of a standard manganous nitrate solution was added as carrier to all starting mixtures, and as suming that after separation from other elements the remaining manganese was in all cases contained in $50.0 \mathrm{ml}$ of solution, take $1.0 \mathrm{ml}$ of the latter $50.0 \mathrm{ml}$ by pipet and transfer to a $50 \mathrm{ml}$ vol. flask.

Add about $40 \mathrm{ml}$ of $3 \mathrm{I} \mathrm{HHO}_{3}$

Add enough solid NaBio, so that a slight amount of excess solid remains in the flask at all times (Fut not enough to occupy a signifioant volume). minute.

Shake for 30 seconds, then dilute with water to $50.0 \mathrm{ml}$. Shake for one

Let stand overnight (or centrifuge if there is need for hurry).

Decant a portion of the supernatant solution of $\mathrm{MnO}_{4}^{-}$and measure its optioal density in a one con cell of the Beckman quartz spectrophotometer. Set the wavelength at the peak near $525 \mathrm{mu}$.

Dilute $2.0 \mathrm{ml}$ of the standard carrier solution to $50.0 \mathrm{ml}$. Take $1.0 \mathrm{ml}$ of this as the starting semple and repeat the procedure just described.

The ratio of the first optical density to the second is the desired chemical yield.

\author{
H. C. Orr
}

$6 / 24 / 49$

$\mathrm{P}-18-6$ 
Element separated: Nanganese

Target material: As

Type of bbdt: 190 llov $\mathrm{D}^{+}$
Procedure by: H. Hopkins, Jr. Time for sep'n: $1 \mathrm{hr}$.

Equipment required: standard

Yield: $\backsim 60 \%$

Degree of purification: $W$ factor of 50 from other activities.

Procedure:

(1) Dissolve As in minimum $\mathrm{HNO}_{3} \& \mathrm{HCl}$, add 5 mo $\mathrm{ln}$ and $1 \mathrm{mg}$ other carriers.

(2) Nake alkaline with $\mathrm{NH}_{4} \mathrm{OH}$, pass in $\mathrm{H}_{2} \mathrm{~S}$ for 1 minute, oentrifuge, wash with $\mathrm{H}_{2} \mathrm{O}$.

(3) Dissolve with hot funing nitric acid and add solid $\mathrm{KClO}_{3}$ to boiling solution to ppt. $\mathrm{InO}_{2}$, add fuming $\mathrm{HNO}_{3}$ and $\mathrm{KCIO}_{3}$ until pptn is comple te.

(4) Centrifuge and wash with $\mathrm{H}_{2} \mathrm{O}$. Dissolve with 1 dp dilute $\mathrm{HCl}$ and $1 \mathrm{dp}$ $\mathrm{H}_{2} \mathrm{O}_{2} \cdot$

(5) Whe to $5 \mathrm{mI}$ volume, $3 \mathrm{~N} H C I$ and add $5 \mathrm{mg} \mathrm{As}$.

(6) Pass $\mathrm{H}_{2} \mathrm{~S}$ into hot solution to ppt $\mathrm{As}_{2} \mathrm{~S}_{3}$.

(7) Repeat pptn of $\mathrm{As}_{2} \mathrm{~S}_{3}$. Malse supnt alkaline, pass in $\mathrm{B}_{2} \mathrm{~S}$ to precipitate uns. Dissolve as before and ppt. $\mathrm{MnO}_{2}$ from a solution containing additional holdbaok carriers.

$6 / 27 / 49$

P-18-21 


\section{CEEMICAL SEPARA TIOIS}

Element separatod: Hingeneso

Target material: Copper foll (ca. $300 \mathrm{mc}$ )

Typo of bbdt: 60 " or 189 " doutorons
Procodurc by: Stemart-Softiky

Time for sop'n: 1-2 hrs for 12 samplos

Equipment roquired: $100 \mathrm{ml}$ boskers filter funnols $40 \mathrm{ml}$ oontrifugo conos

Y1old: $90-100 \%$

Degrec of purifioation: Excellont, factor of approx. $10^{6}$

¿dvantages: Simplicity \& rapidity. (Largo numbor of samplos oan bo run simul tanoously).

Procodure :

(1) Dissolvo oopper in minimum 6I Bro, add 1 in carrior as nitrato.

(2) Diluto to 1-2 $\mathrm{NHMO}$ nda about $100 \mathrm{mg}$ of $\mathrm{KBrO}_{3}$ and boil fn: $5-10$ minutes, or until $\mathrm{lnh}_{2}$ is woll coagulatod.

(3) Filter through Thatman ifte filter papor = irash prooipitato with 6N $\mathrm{HNO}_{3}$ until no Cu bluo shows in sinal wash.

(4) Dissolvo $\mathrm{MnO}_{2}$ through fizior papor into a $40 \mathrm{ml}$ oontrifugo oono. with oonc. HCl. Aid $2 \mathrm{mg}$ Cu carrior. Inko solution strongly ammonioal.

(5) Add a fer orystals of $\left(\mathrm{NH}_{4}\right)_{2} \mathrm{~S}_{2} \mathrm{O}_{8}$ and boil off cxccss persulfate in a hot watar both. $\mathbf{M n O}_{2}$ prooipitatcs almost immediatcly.

(6) Contrifuge, dooant supornatant, and wash prooipitato with diluto $\mathrm{MH}_{4} \mathrm{OH}$.

$7 / 28 / 49$

$P-18-83$ 
CHGICAL SEPARATIONS

Element separatod: Kanganese

Target material: Copper

Type of bbdt: A11 184 " and $60^{\prime \prime}$

Yield; $75 \%$

Degree of purification: $10^{3}$

Advantages: Pure fraction and is not time consuming.

Procedure:

(1) Dissolve the coppor in tho minimum amount of conoent rated $\mathrm{HNO}_{3}$. Boil almost to drynoss, add oarriers ( $\mathrm{Zn}$ and below) inoluding $5 \mathrm{mg}$ of in and make $1 \mathrm{I}$ in HCl.

(2) Preoipitate the copper sulfide. Hake the supernate alkaline with $\mathrm{NH}_{4} \mathrm{OH}$ and preoipitato the sulfides inoluding in with $\mathrm{H}_{2} \mathrm{~s}$.

(3) To the sulfides add conoentrated $16 \mathrm{~N}$ Ero carefully, to dissolvo and make the volumo up to 400 with fuming $\mathrm{HNO}_{3}$. 1 dd 2 or 3 orystals of $\mathrm{KClO}_{3}$ and boil gently for 2 minutcs to preoipitato $\mathrm{MmO}_{2} \cdot$

(4) Wash the preolpitate with $\mathrm{H}_{2} \mathrm{O}$ and dissolve in one drop of $\mathrm{HNO}_{3}$ and $\mathrm{H}_{2} \mathrm{O}_{2}$.

(5) Again add holdback carriers and make $16 \mathrm{~N}$ in $\mathrm{HNO}_{3}$. Preoipitate the $\mathrm{InO}_{2}$ with $\mathrm{KClO}_{3}$ as in step 4 .

(6) The preoipitate may be reifhod as $\mathrm{2mo}_{2}$ and counted.

$8 / 4 / 49$

P-18-132 
Element separated: Iron

Target material: As

Type of bbdt: 190 Mev $D^{+}$
Procedure by: H. Hoplins, Jr. Timo for sepin: $1 / 2 \mathrm{hr}$.

Equipment required: standard

Yield: in 60\%

Degreo of purification: $n$ factor of 50 from other activities.

Prooodure:

(1) Dissolvo As in minimum $\mathrm{HWO}_{3}+\mathrm{HCl}$, add $2 \mathrm{mg} \mathrm{Fe,} \mathrm{Ga,} \mathrm{adjust} \mathrm{to} 6$ II HCl, extract twioe with equal volumes othyl ether.

(2) Wash ether layer 5 times with $1 / 3$ volumes 6 I HCl.

(3) Wash ether layer twice with $1 / 4$ portions $\mathrm{H}_{2} \mathrm{O}$ to remove Fe. Ihke $1 \mathrm{~N}$ $\mathrm{KOH}$ and contrifuge off $\mathrm{Fe}(\mathrm{OH})_{3}$.

(4) Dissolvo in minimum oonc. BCl, dilute to $5 \mathrm{ml}$, add $1 \mathrm{mg}$ carrier, and reppt. $\mathrm{Pe}(\mathrm{OH})_{3}$ with $\mathrm{KOH}$.

(5) Repeat until supernatants (Gallium fraotions) are inaotive.

$6 / 27 / 49$

P-18-23 
CHEIICAL SEPARATIONS

Element separated: Iron

Iarget material; $n l$ \& Bi motal

Type of bbdt: $184^{\prime \prime}$ all part 16108
Procedure by: Goockermann

Timo for sep'n: fow hrs.

Equipment required: Centrifuge, oones

Yiold: $\backsim 30 \%$

Degreo of purification: Decontamination factor $\sim 10^{4}$ from fission \& spallation products.

Adrantages: Pair yield of pure Fe.

Prooodure:

(2) Extract $15 \mathrm{ml}$ of $9 \mathrm{~N} \mathrm{BCl}$ oontaining a liquot of $\mathrm{BNO}_{3}$ sol'n of target and $10 \mathrm{mg} \mathrm{Fe}^{+3}$ wh $15 \mathrm{ml}$ isopropyl other. Wash other twelve timos with $10 \mathrm{ml}$ portions of $7.5 \mathrm{H} \mathrm{HCl}$. Extract $\mathrm{Fe}^{+3}$ into $10 \mathrm{ml} \mathrm{H}_{2} \mathrm{O}$ and ovap dissolved other.

(2) Scavenge with $\mathrm{Sb}_{2} \mathrm{~s}_{3}$ from HCl sol'n. -- repeat.

(3) Scavenge with TeS by $\mathrm{H}_{2} \mathrm{~S}$ pptn.

(4) Ppt $\mathrm{Fo}(\mathrm{OH})_{3}$ with $\mathrm{KH}_{3}$ \& dissolve in $\mathrm{HCl}$.

(5) Rum trice with few ml $\mathrm{HClO}_{4}$ after adding Pu.

(6) Ppt $\mathrm{Fo}(\mathrm{OH})_{3}$ with $\mathrm{NH}_{3}$-- repeat.

(7) Soavenge with $\mathrm{FaSO}_{4}$.

(8) Scerenge with $\mathrm{Ag} I$ (exoess $\mathrm{Ag}$ ).

(9) Scav. with $\mathrm{Cb}_{2} \mathrm{O}_{5}$ by adding $\mathrm{HHO}_{3}+\mathrm{KClO}_{3}$ to oxalate sol'n.

(10) Scav. with $\mathrm{Zr}$ phenylarson to (make precipitation by adding phenylarsenio acid).

(11) Ether ext $\mathrm{FO}^{+3}$ again, ppt as $\mathrm{Pe}(\mathrm{OH})_{3}$ with $\mathrm{NH}_{3}$, filter \& ignite to $\mathrm{Fe}_{2} \mathrm{O}_{3}$ to weigh.

Remarks: This rather involved procedure was designed to separato a very small amount of Fo activity from a large amount of activity spread over the periodio table. It can bo simplified in most cases. There my bo an advantage in doing one of the extractions of $\mathrm{Fe}^{+3}$ out of the ether by treating the ther layer $w$ ith 6-9 N HCI containing $\mathrm{HE}$ and thereby reduoing the Fo to $F_{0}+2$ (insol. In ether). A fow mg of carriers are used in the soavenges.

$7 / 6 / 49$

$I=18-40$ 


\section{CHEIICAL SEPARATIONS}

Elemont separatod: Iron

Target material: in 4 o motal foil

Type of bbdt: $184^{\prime \prime}$ all hifh cne rgy partiolos
Procodure by: Folgor \& Hicks

Time for sep'n: few hrs.

Equipment roquired: Centrifuge oonos, crucible, open top oylindr1oal separatory funnels, stirring motor and flass stirring rods.

Yiold: $\cap 30 \%$

Dogrec of purifioation: Docontamination faotor $\mathrm{n}^{4}$ from fission \& opallation produots. in $10^{6}$ from olomonts 38 to 56.

Adrantagos: Fair yiold of pure Fe.

Prooodure:

(1) Idd $10 \mathrm{Fe}$ to aliquot of target $80 \mathrm{l}^{\prime \prime} \mathrm{n}$. Evap. to drymess twico with conc. HCl. Take up in $15 \mathrm{ml}$ of $9 \mathrm{~N} \mathrm{HCl}$. Extract twioc with $10 \mathrm{ml}$ portions of di-isopropyl other. Wash other twolve timos with $10 \mathrm{ml}$ portions of $7.5 \mathrm{~N} \mathrm{HCl}$. Bxtraot $\mathrm{Fo}^{+3}$ into 2,5-m portions $\mathrm{B}_{2} \mathrm{O}$ and evap dissolved ether.

(2) Soavenge with $\mathrm{Sb}_{2} \mathrm{~S}_{3}$ and $\mathrm{TeS}_{2}$ from 1 N BCl 801 'n. -. ropeat.

(3) Ppt $\mathrm{Fo}(\mathrm{OH})_{3}$ with $\mathrm{NH}_{3}$ wash dissolvo in HCl.

(4) Add Ru and fume twioo with fow ml $\mathrm{HClO}_{4}$.

(5) Ppt $\mathrm{Fo}(\mathrm{OH})_{3}$ with $\mathrm{NH}_{3}$ wash.

(6) Dissolve in $\mathrm{HNO}_{3}$ and soavengo with $\mathrm{BaSO}_{4}$.

(7) Soavongo with $\mathrm{AgI}$ (oxcoss. $\Lambda_{g}$ ).

(8) Ppt. $\mathrm{Fo}(\mathrm{OH})_{3}$ with $\mathrm{NH}_{3}$ (to roduco volume) wash and dissolvo in cono. $\mathrm{HIO}_{3}$

(9) Sdd $\mathrm{Cb}$ and scavonge with $\mathrm{Cb}_{2} \mathrm{O}_{5}$ by adding $\mathrm{KBrO}_{3}$ and $\mathrm{HMO}_{3}$ to oxn la to soln.

(10) Whe $3 \mathrm{~N}$ in $\mathrm{HrO}_{3}$ and $\mathrm{HF}$. Add $\mathrm{Ba}$ and senvonge with BaZrF 6 twice.

(11) Ppt $\mathrm{Fa}(\mathrm{OH})_{3}$ with $\mathrm{MH}_{3}$. Trash. Dis802ve in $9 \mathrm{~N} \mathrm{HCl}$.

(12) Ether ext $\mathrm{Fe}^{+3}$ again, re-extract into $\mathrm{H}_{0} \mathrm{O}$, ppt as $\mathrm{Fc}(\mathrm{OH})_{3}$ with $\mathrm{NH}_{3}$, wash, filtor \& ignite to $\mathrm{Fo}_{2} \mathrm{O}_{3}$ to wolgh. (24.3 $\mathrm{mg} \mathrm{FC} \mathrm{O}_{3}=10^{3} \mathrm{mg} \mathrm{Fo}$ ) 
Romarks: This rather involved procodure was desiened to scparato a very small omount of Fo activity from a largo amount of activity sproad ovor the periodic tablo. It can be simplified in most cases. Thoro may bo an advantago in doing one of the oxtractions of $\mathrm{Fe}^{+3}$ out of the other by treatine the gthor layer with 6-9 N HCl containing $\mathrm{Hg}$ and thereby reducing the $\mathrm{Fo}$ to $\mathrm{Fe}^{+2}$ (insol. in ether). - $1-2 \mathrm{mg}$ of carricrs arc usod in the scavenges. 


\section{CEENICAL SSPRRTIONS}

Elomont separated: Iron

Target matcrial: Copper foils (300-500 mE Ou)

Type of bbdt: Deuterons 60", 18/"
Procodurc by: Stewart, Softly

Timo for sop'n: 2-3 hrs.

Equipment required: beakors, filter funnel $40 \mathrm{ml}$ ocntrifuge conos separatory funnols

Yic Id: $\quad 80-100 \%$

Dogroo of purification: factor of in $10^{6}$

Advantages: High purity. Small amount of carricr.

Proocduro:

(1) Dissolvo copper in minimum $6 \mathrm{~N} \mathrm{HNO}_{3}$ and diluto to 1-2 $\mathrm{N} \mathrm{HNO}_{3}$. Add $1 \mathrm{mg} \mathrm{Fc}_{\mathrm{g}}$ and $1 \mathrm{mg}$ in carricr as nitrate.

(2) Add about $0.1 \mathrm{~g} \mathrm{KBrO}_{3}$ end boil for 5-10 minutes or until $\mathrm{MnO}_{2}$ is well coceulated. "Filtor through thatman ":t2 filtor paper and catch filtratc in a $40 \mathrm{ml}$ oontrifuge oono. Thsh precipitato with $2 \mathrm{~N} \mathrm{BrO}_{3}$ until wresh is colorless.

(3) Prceipitato Fo(OH) 3 with cxcess $\mathrm{NH}_{4} \mathrm{OH}$, contrifuge, and docant supornatant. Dissolvo prcoipitato in HCl and rcpont until supornatant is colorlcss. Aidd $2-3 \mathrm{mg}$ Cu cairicr as chlorido and ropect twioc moro.

(4) Dissolvo final $\mathrm{Fo}(\mathrm{OH})_{3}$ in 1 drop of $\mathrm{HCl}$ and transfor to a scparatory funnol with $6 \mathrm{~N} \mathrm{HCl.} \mathrm{Add} \mathrm{an} \mathrm{cqual} \mathrm{volums} \mathrm{of} \mathrm{di-cthyl} \mathrm{cther}$ pro-saturatod with $\overline{6 N}$ HCl and extract tho Fo. Draw aquoous 1ayor into a 2nd soparatory funnel and repcat. Do a 3rd extraotion aftor adding $1 \mathrm{mg}$ Fo carricr as chlorido.

(5) Colloot tho other layors in a $40 \mathrm{ml}$ contrifugo oono with a small amount of wator. Evaporato off the solvent in a hot water bath. Rooover FC as $\mathrm{Fo}(\mathrm{OH})_{3}$ by procipitation with $\mathrm{NH}_{4} \mathrm{OH}$.

Remarks:

It was found that unlose spcoific scparation for in is dono, tho oontamination in the iron fraction is approoiablo. (Stop 2).

Dircet cvaporation of an $\mathrm{FCCl}_{3}$ solution givos considorablo loss, so it is bottcr to ppt tho iron and ${ }^{3}$ re-dissolvo in somo acid othor than ECl. (Stop 5).

\section{$7 / 28 / 19$}


Element separated: Iron

Procedure by: Batzel

Target material: Copper

Time for sep'n: 40 min.

Type of bbdt: All 184" - 60"

Equipment required: Standard

Yield: $95 \%$

Degree of purification: $10^{3}$

Advantages: Pure fraction with good yield.

Procedure:

(1) The target may be dissolved in the minimum amount of either concentrated $\mathrm{BrO}_{3}$ or concentrated $\mathrm{BCl}$ and $\mathrm{H}_{2} \mathrm{O}_{2}$.

(2) Five of $\mathrm{Fe}$ are added as carrier and the solution made 6 If in $\mathrm{HCl}$ - total volume $6 \mathrm{cc}$.

(3) Extract 3 times with othyl aoetate $-3 \mathrm{ml}$ portions. Whas the othyl ace tate 3 times with $1 / 3$ volume of $6 \mathrm{~N} \mathrm{HCl}$.

(4) Bxtraot the iron from the ethyl acotate layer with 3 co of distilled water. Again make $6 \mathrm{~N}$ in HCl and re-extraot as listed in step 3.

(5) Finally after washing the ethyl acotate thoroughly with $6 \mathrm{~N} \mathrm{HCl}$, extract the iron into 3 oo of distilled water and plate.

(6) The chemical yield oan be determined oalorimotrically by taking aliquots from the final iron solution (See 26-6).

Remarks :

(1) Holdback carriers need not be added for other elements, but will not interfere with this prooedure if added. 


\section{DETERITKATION OF Fe CONCEHTRATION}

The following procedure may be used for the colorimetric analysis of iron.

Prepare a curvo of iron concentration vs \% transmission as follows:

(1) To $10 \mathrm{ml}$ volumetric Masks add 5, 10, 15, 20, 25, and 30 gamma of $\mathrm{Fe}$ from the standard solution.

(2) Add $200 \lambda$ of a $10 \%$ solution of hydroxylamine hydrochloride. Diluto to 5 oc and add $500 \lambda$ of a 0.1 percent water solution of orthophonanthral ine.

(3) Add one arop $\mathrm{MH}_{4} \mathrm{OH}$ to bring the $\mathrm{pH}$ to the range of 4 to 9 . Dilute to 1000 and alfor color to develop for 5 minutes.

(4) Lasure the $\%$ transmission of the samples a gainst a blank containing the hydroxylamine and orthophenanthraline at a wave length of 508 millimicrons on a Bockman Spectrophotometer.

(5) The ourve follows Beor's Law. oedure.

In anslyzing the samplos duplicates should be run using the above proR. Batzol 
Elomont scparated: Iron

Targot motorial: cobalt

Type of bbdt: Noutrons - $60 "$
Procoduro by: R. C. Lilly

Timo for sop'n: 6 hours

Equipment roquirod: Boakors, funnols

Yioldi $\sim 100 \%$

Degree of purification: oxcollont at least factor of 100 from othor activitics prescrt.

Advrntages: Simplicity

Procoduro:

(1) Dissolvo the Co target in $\mathrm{HNO}_{3}$. Removo tho nitrates by boiling with $\mathrm{HCl}$ until no brown fumes aro ovolvod.

(2) 1 dd $2 \mathrm{mg} F C, 10 \mathrm{mg} \mathrm{Ni}, 10 \mathrm{mg} \mathrm{Zn}$ and $50 \mathrm{mg} \mathrm{U}$ as tho ohloride solutions. Dilute and ppt with oxooss $\mathrm{NH}_{4} \mathrm{OH}$. Coagula to the ppt and filtor it quickly through quantitative paper. Dissolve tho ppt through tho filtir with warm $\mathrm{BCl}$ and ropoat tho pptn.

(3) Dissolvo tho ppt through the filter with warm $B C 1$, collcoting the so''n in a $40 \mathrm{ml}$ contrifugo tubo. Add hold-brok carriors of $\mathrm{Cu}, \mathrm{Ni}, \mathrm{Zn}$ and $\mathrm{C}_{0}$ and do throo moro $\mathrm{NH}_{4}$ OH ppt'ns, dissolving tho ppt in HCl caoh timo.

(4) Dissolve the final ppt in $\mathrm{HCl}$ so as to give an $8 \mathrm{~N} \mathrm{HCl} \mathrm{sol'n;}$ and extract tho Fo with 3 or 1 portions of 18opropyl other. Combino other layers, add $\mathrm{H}_{2} \mathrm{O}$, boil to a low volumo, and fumo with $\mathrm{H}_{2} \mathrm{SO}_{4}-\mathrm{H}_{2} \mathrm{O}_{2}$ until arganic matter is destroyod.

(5) Take up in $\mathrm{HCl}$ and ppt with $\mathrm{NH}_{\mathrm{OH}}$ - $\left(\mathrm{NH}_{4}\right)_{2} \mathrm{CO}_{3} 801$ 'n., discarding tho supornatent. Dissolvo in ECl and ropeat tho ppt in twico. Dissolvo the final ppt if desirod, or 190 as is.

Romarks:

The ppt' $n$ of the $F_{0}$ and $U$ from the bulk of the cobalt is bost mado by quic'lly adding a large excess of $\mathrm{NB}_{4} \mathrm{OH}$ to the warm diluto co sol'n.

Ni trates mast be avoided throughout to prevent oxtraotion of tho $U$ by the ether.

This proocduro was usod for the proparation of purc compounds of $\mathrm{Fo}^{59}$; for identificaticn of aotivitios alone, it would bo advisablo to take an aliquot aftor dissolving tho target.

Paper is usce for tho filtration in (2) booause the ppt tonds to olog a sintorod filtor if suotion is appliod.

$8 / 19 / 49$

P-18 237 
Eloment sopamtod: Iron

Target matcrial: Mnganoso

Typc of bbdt: Dcuterons - 60"
Procoduro by: R. C. Iilly

Time for sep'n: $\quad 4-6$ hours

Equipment requirod: bockers, funnols, sintered glass funnols and suparatory funno is.

Yicld: $\sim 100 \%$

Dogreo of purification: exeollent at last factor of 100 from other activitios prescnt.

idrantagos: Largo amount of lin does not provont purificotion of the fo.

Frocedure:

(1) Dissolvo in target in tho loast possiblo amount of $6 \mathrm{~N} \mathrm{HCl.}$ Add 2-5 mg Fo and $25 \mathrm{mg}$ Cu as the chlorido solutions.

(2) Mako $0.3 \mathrm{~N}$ in $\mathrm{HCl}$, hoat to boiling, and pass in $\mathrm{H}_{0} \mathrm{~S}$ to ppt tho coppor group as sulfidos. Filtor. Wash the ppt with $0.1 \mathrm{~N}$ HCI and discard it. Add wash to filtrate.

(3) Boil filtrato to $50 \mathrm{ml}$ volume, oxidize Fo with $5 \mathrm{ml}$ of $30 \%$ $\mathrm{H}_{2} \mathrm{O}_{2}$ and boil off oxooss $\mathrm{H}_{2} \mathrm{O}_{2} \cdot \mathrm{MmO}_{2}$ may ppt at this point, but it will rodissolvo as the $\mathrm{H}_{2} \mathrm{O}_{2}$ is oxpellod.

(4) Itko al kaline with $\mathrm{NH} \mathrm{OH}$ and ppt the $\mathrm{FO}$ as $\mathrm{FC}(\mathrm{OH})_{3}$. Some $\mathrm{Mn}$ vill also ppt; it can be disrogardod and will bo romovod littor in the procodure. This stop separatos the Fo from any largo amounts of salts which my be present to interfero with tho other extraction which follows.

(5) Dissolve ppt through flltor with werm $9 \mathrm{~N} \mathrm{HCl}$; tho rosulting volumo should bo $10-20 \mathrm{ml}$. Extract tho Fo with 3 or 4 portiona of isopropyl ather. Combino tho othor laycrs, add $\mathrm{H}_{2} \mathrm{O}$, boil to a low volumo, and fumo with $\mathrm{H}_{2} \mathrm{SO}_{4}-\mathrm{H}_{2} \mathrm{O}_{2}$ until orgnicic mattor is dostroyod.

(6) Take up in $\mathrm{HCP}_{1}$ and ppt $\mathrm{Fo}(\mathrm{OH})_{3}$ with $\mathrm{NH}_{4} \mathrm{OH}$, disoarding the supornatant. Dissolvo the ppt if desirod, or use as is.

Remarks :

This procoduro was used for proparing puro compounds of $\mathrm{Fo}^{55}$; tho procodure timo oould bo shortonod for uso on shortor-livod isotopos.

$8 / 19 / 49$ 


\section{CHEIICAL SEP:RAITONS}

Elomont sopnratod: Iron

Targot matorial: $N 1$ (soparated isotopes)

Typo of bbdt: Noutrons - $60 "$

Yiold: $\sim 90 \%$

Degroc of purification: fnctor of 5

Advnntages: Specd

Procodure:

(1) Dissolv $\mathrm{Ni}$ foil, woighing $3-5 \mathrm{mg}$ in a $10 \mathrm{ml}$ boakor contnining $0.5 \mathrm{ml}$ hot conc. $\mathrm{HNO}_{3}$. Add $2 \mathrm{mg} \mathrm{Co}, 2 \mathrm{mg} \mathrm{Cu}$, and $2 \mathrm{mg}$ Fo $\mathrm{as}$ $2 \mathrm{ml}$ of tho ohloride solins.

(2) Tronsfor to a $5 \mathrm{ml}$ oontrifugo oono and ppt with $\mathrm{MH}_{4} \mathrm{OH}$. Coagulato the ppt by immorsing tho oono in a boiling $\mathrm{H}_{2} \mathrm{O}$ bath for a fow sooonds and contrifuge. Removo tho supernatint.

(3) Dissolvo the $\mathrm{Fo}(\mathrm{OH})_{3}$ ppt in a fow drops of cono HCl. Add $2 \mathrm{mg}$ $\mathrm{Co}, 2 \mathrm{mg} \mathrm{Cu}$, and $2 \mathrm{mg} \mathrm{Ni}$ as $2 \mathrm{ml}$ of the chloride sol'ns, and transfor the samplo to a scoond $10 \mathrm{ml}$ boakor.

(4) Ppt with $\mathrm{NH}_{4} \mathrm{OH}$, ooagulate the ppt by hoating and filter through a 742 Thatman filtor papor disc hold in a Gooch oruoiblo or Hirsch funnol. Dry with a fov drops of acotone and mount under tape. 
Elomont soparated: Iron

Target material: Cu (50-100 mg)

Typo of bbdt: Douterons - 184"

\author{
Prooedure by: R. C. Lilly \\ Timo for sop'n: 45 minutes \\ Equipmont requirod: boakers, \\ funnels, $40 \mathrm{ml}$ contrifuge \\ tubo, small oontrifugo tubo.
}

\author{
Y101d: $\sim 100 \%$ \\ Dogroo of purification: Factor of 100 \\ Advantages, Simplicity \\ Procedure:
}

(1) Dissolve $\mathrm{Cu}$ targot in conc. HCl containing a fow drops of conc $\mathrm{HNO}_{3}$. Boil off the exoess $\mathrm{HNO}_{3}$. Add $3 \mathrm{mg} \mathrm{Fe,} 10 \mathrm{mg} \mathrm{Co,} 10 \mathrm{mg} \mathrm{Ni}$, and $5 \mathrm{mg} \mathrm{Zn}$ as the chlorido solins.

(2) Dilute to $50 \mathrm{ml}$ with $\mathrm{H}_{2} \mathrm{O}$ and hoat to boiling. Ppt Fo(OH) 3 by odding $\mathrm{NH}$ OH in oxcoss and coagulato the ppt woll by hoating. Filtor the $\mathrm{Fo}(\mathrm{OH})_{3}$ ppt through "42 Thatman papor in a glass funnel and wash with a small amount of $1 \% \mathrm{NH}_{4} \mathrm{Cl}$ sol'n.

Tho filtrato contains the Cu, Co, $\mathrm{Ni}$ and $\mathrm{Zn}$ fractions and is worked up soparatoly as desoribod in the procoduros for Co and Ni from Cu targots, Hos. 27-5 and 28-6.

(3) Mash tho $\mathrm{Fo}(\mathrm{OH})_{3}$ ppt woll with $1 \% \mathrm{NH}_{4} \mathrm{Cl}$ and discard tho wash ings. Dissolve the ppt through tho paper with warm $6 \mathrm{~N} \mathrm{HCl}$ and oolloot tho $B 01$ in in a $40 \mathrm{ml}$ contrifugo cono.

(4) Add $10 \mathrm{mg}$ Co and $10 \mathrm{mg} \mathrm{Ni}$ as the chlorido sol'ns as hold-baok carriers; placo tho oono in a hot $\mathrm{H}_{2} \mathrm{O}$ bath, and ppt $w i$ th $\mathrm{NH}_{4} \mathrm{OH}$. Coagulato tho ppt by hoating, ocntrifugo, and discard tho suppornatant. Redissolvo tho ppt in HCl.

(5) Repont stop (4) twico.

(6) Aftcr the third pptin. oyole abovo, dissolvo the ppt in tho correot amount of $\mathrm{mCl}$ and $\mathrm{H}_{2} \mathrm{O}$ to givo $10 \mathrm{ml}$ of $80 \mathrm{l} \mathrm{n}, 8 \mathrm{~N}$ in $\mathrm{HCl}$.

(7) Extraot Fo with four $10 \mathrm{ml}$ portions of isopropyl othor. Combino ethor layere, add $\mathrm{H}_{2} \mathrm{O}$, boil to a low volumo, and fume with $\mathrm{H}_{2} \mathrm{SO}_{4}-\mathrm{H}_{2} \mathrm{O}_{2}$ until or Enic matter is dostroyed.

(8) Toko up in Eil, transfer to a small oentrifugo cono, and ppt with $\mathrm{NH}_{4} \mathrm{OH}$. Contrifugo and discard the supernatant. Proparo for counting as desirod.

Romarks: Soc Hillobrand and Lundoll (ipplied Inorgcnic Analysis) for further information on tho extraction of Fo with isopropyl cther. 
CFE:-ICAL STPARATIONS

Element separated: Cobalt

Target terin 1: As

Type of bbdt: $190 \mathrm{Lev} \mathrm{D}^{+}$
Procedure by: H. Hopkins, Jr.

Time for sep'n: $1 \mathrm{hr}$.

Equipment required: standard

Yield: $\backsim 70 \%$.

Degree of purification: $\sim$ factor of 100 from other activities.

Procedure:

(1) Dissolve $\mathrm{As}$ in minimum $\mathrm{HNO}_{3}+\mathrm{HO}$, add $2 \mathrm{mg}$ So \& Ge carrier, $5 \mathrm{mg} \mathrm{Co}$.

(2) Make alkaline with $\mathrm{NH}_{4} \mathrm{OH}$, pass in $\mathrm{H}_{2} \mathrm{~S}$ rapidly for 1 minute only. Cen trifuge immediately.

(3) Dissolve in minimum conc. $\mathrm{HCl}$, add $1 \mathrm{mg} C \mathrm{Cu}$, ppt CuS from hot $1 \underline{\mathrm{N}} \mathrm{HCl}$.

(4) Add other carriers, evaporate to small volume, make $6 \mathrm{NHCl}$, extract 4 times with equal volume ethyl ether.

(5) Evaporate to near dryness, add $\mathrm{H}_{2} \mathrm{O}$ to $2 \mathrm{ml}$ volume, add $\Lambda$ equal volume solid KSCN, extraot 4 times wi th ${ }^{2} 2$ ml amyl aloohol.

(6) Extract out of amyl alcohol with $4 \mathrm{ml} \mathrm{IN} \mathrm{KOH.}$

(7) Dissolve with $\mathrm{HCl}$ and reppt hydroxide with KOH.

(8) Dissolvo in minimum acotic acid, dilute to $4 \mathrm{ml}$, saturate wrth $\mathrm{KCl}$, and add $\mathrm{KNO}_{2}$ until pptn of $\mathrm{K}_{3} \mathrm{Co}\left(\mathrm{NO}_{2}\right)_{6}$ is complete. 
Element separated: Cobalt

Procedure by: Stewart Softiky

Target material: Copper foils (oa. $300 \mathrm{mg}$. Cu) Time for sep'n: 4-6 hrs. Type of bbdt: Deuterons 60" or 184"

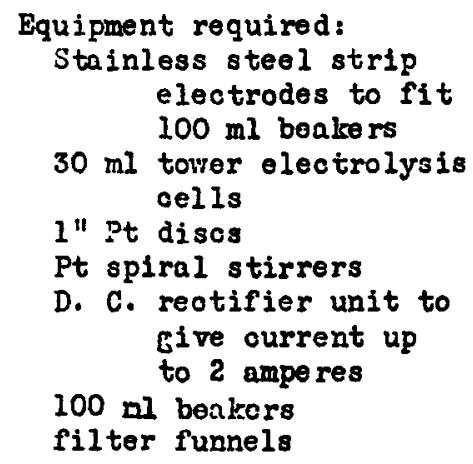

Y1e2d: $\quad 90-100 \%$

Degree of purification: Complete separation at least by factor of $10^{5}$ from $\mathrm{Mn}, \mathrm{FO}, \mathrm{Ni}, \mathrm{Cu} \& \mathrm{z}_{\mathrm{n}}$.

Advantages: Wthod by which a large number of samples can be run simultaneosly for excitation functions.

Prooedure:

(1) Dissolve Cu foll in minimum dilute $\mathrm{HNO}_{3}$, Add $1 \mathrm{mg} . \mathrm{Co}, \mathrm{Ni}, \mathrm{Mm}$ carriers as nitrates, and 2 drops cono. $\mathrm{H}_{2} \mathrm{SO}_{4}$. Dilute to about 20 ml. with distilled water.

(2) Flectroceposit oopper on stainless steel strip cathode set into beaker in whioh tho foil was dissolved, using a rotating Pt spiral anode at 2-3 volts, 1-2 amperes.

(3) Then solution is water white, remove the eleotrodes, add $1 \mathrm{ml}$. cono. $\mathrm{H}_{2} \mathrm{SO}_{4}$ and evaporate to $\mathrm{SO}_{3}$ fumes to remove $\mathrm{HNO}_{3}$.

(4) Dilute to $35-50 \mathrm{ml}$ and saturate with $\mathrm{H}_{2} \mathrm{~S}$ to precipitate rosidual Cu. Filter. Boil filtrate to cxpel $\mathrm{H}_{2} \mathrm{~S}$, add $2 \mathrm{mg} \mathrm{Cu}$ carrier as chloride and repeat.

(5) Boil filtrate 5 minutes to expel $\mathrm{H}_{2} \mathrm{~S}$, make solution slightly ammonical, then add $1-2 \mathrm{ml} 1 \%$ dimethylglyoxime in ethanol to ppt NiDMG. Filter. Wash ppt wh hot water.

(6) Acidify filtrate with $\mathrm{ENO}_{3}$ \& evaporate to $\mathrm{SO}_{3}$ fumes to destroy alcohol. Add a fow drops of conc. $\mathrm{HCl}$ and again take to $\mathrm{SO}_{3}$ fumes to insure removal of $\mathrm{NO}_{3}^{-}$.

(7) Transfer solution to a $30 \mathrm{ml}$ tower electrolysis cell fitted with a $1^{\prime \prime}$ Pt diso cathode, make strongly ammonical, and electrolyze at $1-2$ amperes for about 30 minutes, using a slowly rotating Pt 


\section{$27-2$ (page 2)}

anode. Cobalt deposits as a smooth adherent plato on the cathodo. $\mathrm{ImO}_{2}$ deposite at the same time on the anode.

(8) "hon co is completely deposited, replace the eleotrolyte with distilled water while the current is still on. Removo the anode quickly to prevont 801 'n of the $\mathrm{MnO}_{2}$, pour off the water and rinse the oobalt plate with alcohol.

Romarks :

(In step (5) if solution is too strongly ammonical at this point, MiDlig will be incompletely preolpitated.)

(In step (7) $\mathrm{NH}_{4} \mathrm{OH}$ should be added periodically during the electrodeposition. Current should be kept lower than 2 amperes to $E$ ive a smooth adherent plate.) 
Element separated: Cobalt

Target material: Copper

Type of bbdt: all - 184" \& 60"
Procedure by: Batzel

Time for sep'n: 40 min.

Equipment required:

Standard

Yiold: $\quad 30-40 \%$

Degree of purification: Factor of at least 100 from other activities present.

Prooodure:

(1) Dissolvo copper in minimum amount of concentrated ERro, and boil to dryness or with FCl to destroy $\mathbb{H N O}_{3}$. Lad $5 \mathrm{mg}$ Co oarrior and 1-2 mg of the neighboring elements to get as holdbacks.

(2) Remove copper as sulfide from a $1 \mathrm{~N}$ HCl solution. Thash the precipitato with IN HCl saturated $\overline{\text { Fith }} \mathrm{H}_{2} \mathrm{~S}$.

(3) Boil supe rnate to remove $\mathrm{H}_{2} \mathrm{~S}$ and neutralize with $\mathrm{KOH}$. Inke 2-3 $N$ in acetio acid. Saturate about $5 \mathrm{cc}$ of water with $\mathrm{knN}_{2}$ and add $0.3 \mathrm{cc}$ of acetic acid. Hcat and add to the hot solution of cobalt.

(4) Allow to settlo for 5 minutes in a steam bath. Cool, and oentrifugo. Tash with a $5 \% \mathrm{KMO}_{2}$ solution acidified with aootio aoid.

(5) Dissolve the ppt with concentrated HCl aga in add 1 mg eaoh of holdback carriers and reprecipitate.

(6) Woigh as the potassium cobnltinitrito. 
CHEYICAL SEPARATIONS

Element separated: Cobalt

Procedurc by: Folgor

Target material: un $4 \mathrm{gm}$. U motal foil

Time for sop'n: in $21 / 2 \mathrm{hrs}$.

Typo of bbdt: 184" full onerey particles

(high enorgy fission)

Equipmont roquirod: Contrifuge, cones, ico bath, $110^{\circ}$ ovon. $\mathrm{NH}_{3}$ gas.

Yiold: $50 \%$ possiblo

Dogroo of purifiuation: Separates from all clements by a factor of at loast $10^{4}$ separates from elemonts 38 to 56 by a factor of $n 10^{8}$.

Advantages: A small amt. of co may be obtainod pure from largo yiolds of contamimnts.

Prooodure:

(1) Oranium target is dissolvod in oono. BCl (plus a small amt. conc. $\mathrm{HNO}_{3}$ to olear up the sol'n) or in oono. HNO (should be $>I O N$ ). Use $\sim 1 / 4$ (or moro) of target sol'n for aliquot. Add 10-20 $\mathrm{mg}$ Co oarricr and mako basic with $\mathrm{NH}_{3}$.

(2) Contrifuge and whsh ppt trice with sat'd aquoous $\mathrm{NH}_{3}$. Combino supornatant and washings.

(3) Soavengo twice with $\mathrm{Fo}(\mathrm{OH})_{3}$, twioc wi in $\mathrm{BaCO}_{3}$ \& $\mathrm{SrCO}_{3}$ (add snt'd $\mathrm{Na}_{2} \mathrm{CO}_{3}$ and check pH to be surc sol'n is basic onough, $\sim \mathrm{pH} 10$ ).

(4) inko $0.7-0.8 \mathrm{~N}$ in $\mathrm{HCl}$. Soavengo with CuS, CdS, $\mathrm{RO}_{2} \mathrm{~S}_{7}$ (for $\mathrm{Tc}$ ) $\mathrm{HgS} \mathrm{PdS}_{2}$ (1-2 mg of carriors).

(5) Make basic with $\mathrm{NH}_{3}$ and ppt $\cos \mathrm{w} . \mathrm{H}_{2} \mathrm{~S}$. Wash to removo all $\mathrm{NH}_{4}^{+}$ Dissolvc in 1 co conc. $\mathrm{HMO}_{3}$. Dilute to $4 \mathrm{~N}^{2} \mathrm{ENO}_{3}$ and scavengo with 1-2 1 ? $\mathrm{Cl}$ twicc.

(6) Makc basic with KOH to ppt $\mathrm{Co}(\mathrm{OH})_{2}$ (upon hoating goos to $\mathrm{Co}(\mathrm{OH})_{3}$ Contr. and wash. Dissolvo ppt in 3 co 2-3 N HAo. $\Lambda$ ad $2 \mathrm{mg} \mathrm{Ni}$ holdback and hoat.

(7) Add 3-4 oc $6 \mathrm{~N}$ Hic sat'd with $\mathrm{KNO}_{2}$ hot (Cautionl Bowaro of foaming ovor). Digost 10 min hot. Chill in ioc bath to rotard bubblos and contrifugo $\mathrm{K}_{3} \mathrm{CO}\left(\mathrm{NO}_{2}\right)_{6} \cdot 21 / 2 \mathrm{H}_{2} \mathrm{O}$ (yollow).

(8) Wash, and dissolve in conc. HCl (with heating - groon sol'n is obtainod).

(9) Ropoat stops (3) through (8). Thon ropoat (6) and (7).

(10) Bash twioo with $\mathrm{H}_{2} \mathrm{O}$, EtOH, Et ${ }_{2} \mathrm{O}$. Filtor, dry at $110^{\circ} \mathrm{C}$ for 5 min. Woigh as $\mathrm{X}_{3} \mathrm{Co}\left(\mathrm{NO}_{2}\right)_{6} \cdot \mathrm{H}_{2} \mathrm{O}$.

\section{Romarks :}

(1) In step (6), the $\mathrm{Co}(\mathrm{OI})_{2}$ ppt bocomos groy-brown on hoating in tho 
water bath. This doos not interforo with the proceduro.

(2) For additional information sec Scott, "Standard Ifothods of Chomioal Analysis," D. Van Nostrand Co., Inc., Now York, Ed. 5 Vol. I, Pp 305-14. 
Element separated: Cobalt

Target material: $\mathrm{Cu}, \mathrm{NI}$

Type of bbdt: Douterons - 184"

Neutrons - 60"
Prooedure by: R. C. Lilly

Time for sep'n: 1 hour

Equipment required: Beakers, funnels, fine sintered class filter, $50 \mathrm{ml}$ separatory funnels (3)

Yield: $N 90 \%$

Degree of puriflcation: Fector of 100

Advantages: Purity of co product

Procedure: A, B \& C have steps 4-9 in common.

A. Cobalt from $\mathrm{Ni}_{i}$ (separated isotopes) + $p, d, n-60 "$

(I) Dissolvo $\mathrm{Ni}$ foll, weighing 3-5 mg., in a few drops of conc $\mathrm{HNO}_{3}$ and boil off $\mathrm{HNO}_{3}$ with successive portions of HCl. Add $2 \mathrm{mg}$ $\mathrm{Co}, 2$ mg $\mathrm{Fe}$ and $\mathrm{S} \mathrm{mg}, \mathrm{Cu}$ as the ohloride solins.

(2) Dilute to $50 \mathrm{ml}$ with $\mathrm{H}_{2} \mathrm{O}$ and heat to boiling. Ppt $\mathrm{Fe}(\mathrm{OH})_{3}$ by adding $\mathrm{MH}_{4} \mathrm{OH}$ in excess and ooagulate the ppt well by heating. Filter the $\mathrm{Fe}(\mathrm{OH})$ ppt through 142 Fihatman paper in a glass funnel and wash with a small amount of $1 \% \mathrm{NH}$ Cl sol'n. (The ppt is worked up separately as described in the procedure for Fo from Cu targets, No. 26-10). Make the filtrato slightly acidic with $\mathrm{HCl}$. Add conc $\mathrm{NH}_{4} \mathrm{HSO}_{3}$ sol'n dropwise until all of the $\mathrm{Cu}$ is reduced (as show by the lack of any localized blue oolor when a few drops of conc $\mathrm{NH}_{4} \mathrm{OH}$ are added). Add solid $\mathrm{NH}_{4} \mathrm{SCN}$ dissolved in a small amount of $\mathrm{H}_{2} \mathrm{O}$ until ppt'n is oomplete.

(3) Coagulate the CuSCN ppt by heating and filter it through a double thiokness of 742 Whatman paper in a glass funnel. Disoard the ppt. Boil the filtrate to a volume of $10 \mathrm{ml}$ to expel $\mathrm{SO}_{2}$ and trensfer to a $50 \mathrm{ml}$ separatory funnel.

B. Cobalt from Cu $(50-100 \mathrm{mg})+\mathrm{d}-184^{n}$

(1) Dissolve Cu target in conc. HCl containing a few drops of cono. $\mathrm{HrO}_{\mathrm{g}}$. Boil off the excess $\mathrm{HrO}_{3}$. Add $2 \mathrm{mg} \mathrm{Co,} 2 \mathrm{mg} \mathrm{Fo,}$ and 2 mg tif as the chloride sol'ns.

(2) Dilute to $50 \mathrm{ml}$ with $\mathrm{H}_{2} \mathrm{O}$ and heat to boiling. Ppt Fo(OII) 3 by adding $\mathrm{UH}_{4} \mathrm{OH}$ in exoess and coagulate the ppt well by heating. Fifter the $\mathrm{Fe}(\mathrm{OH})_{3}$ ppt through i"42 thatman paper in a glass funnel and wash with a small amount of $1 \% \mathrm{NH}_{4} \mathrm{Cl}$ sol'n. (The ppt is worked up separately as described in the procedure for $\mathrm{Fe}$ from $\mathrm{Cu}$ targets, No. 26-10). Mhke the filtrate slirhtly acidio with $\mathrm{BCl}$. Add conc. $\mathrm{NH}_{4} \mathrm{HSO}_{3}$ sol'n droprise until all of the $\mathrm{Cu}$ is reduced (as shown by the lack of any 
localized blue color when a fow drops of conc $\mathrm{MH}_{4} \mathrm{OH}$ a re addod). Add solid $\mathrm{NH}_{4} \mathrm{SCN}$ dissolvod in a small amount of $\mathrm{H}_{2} \mathrm{O}$ until ppt 'n is complete.

(3) Coagulate the CuSCN ppt by heating and filter 1t through a double thickness of "A2 thatman paper in a glass funnel. Discard the ppt. Boil the filtrate to a volume of $10 \mathrm{ml}$ to expel $\mathrm{SO}_{2}$ and transfer to a $50 \mathrm{ml}$ separatory funnel.

C. Cobalt from Cu (0.1-0.5 gms) $+n-184^{n}$

(1) Dissolve Cu target in $10 \mathrm{ml}$ of hot $6 \mathrm{~N} \mathrm{HNO}_{3}$ in a small beaker and boil off $\mathrm{ENO}_{3}$ with successive portions of HCl. Add 2 mg Co and $2 \mathrm{me} N \mathrm{Ni}$ as the chloride sol'ns.

(2) Add $\mathrm{H}_{2} \mathrm{O}$ and $\mathrm{HCl}$ so as to give 2 volume of $25-30 \mathrm{ml}$ with $0.3 \mathrm{~N}-0.5 \mathrm{~N} \mathrm{HCI}$. Feat to boiling and pass in $\mathrm{H}_{2} \mathrm{~S}$ to ppt Cus.- Coagulate the ppt by heating and filtor it through a small fine sintered Elass filter. Fash the ppt with a small amount of $\mathrm{H}_{2} \mathrm{O}$ and discard it.

(3) Boil the filtrate to a volume of $\sim 10 \mathrm{ml}$ and then transfor it to a $50 \mathrm{ml}$ separatory funnel.

In all three of the above cases continue as follows:

(4) Add 5 gms of solid $\mathrm{NH}_{4} \mathrm{SCN}$ and shake until all of the orystals aro dissolved. Extract Co from this sol'n by shaking with an equal volume of ethyl ether - anyl a.lcohol (1:1)

(5) Draw off the $\mathrm{H}_{2} \mathrm{O}$ layer from this extraotion into a second $50 \mathrm{ml}$ separatory funnel, discarding the fow drops of mixed sol'ns whioh remain in the stopoock.

(The $\mathrm{N} 1$ is contalned in the $\mathrm{H}_{2} \mathrm{O}$ layer and is worked up separately as described in the prooedure for $\mathrm{Ni}$ from Cu targots. No. 28-6).

(6) Add $10 \mathrm{ml}$ of $6 \mathrm{~N} \mathrm{NH}_{4}$ OH to the organio layer in the first separatory funnel to destroy the complex and reextraot the Co.

(7) Draw off this ammoniacal layer into a third $50 \mathrm{ml}$ separatory funnel and make it slightly acidic with HCl. $\Lambda$ dd 2 mb Ni as the ohloride sol in and ropeat the extraotion as in step (4) above.

(8) Draw off the $\mathrm{H}_{2} \mathrm{O}$ layer and discard it. Treat the organic layer with $\mathrm{NH}_{4} 6 \mathrm{H}$ as described in stop (6) above.

(9) Draw off the ammoniacal layer into a $50 \mathrm{ml}$ beaker, boil to a volum of $5 \mathrm{ml}$, and $\mathrm{ppt}$ CoS by adding $\mathrm{IRH}_{4} \mathrm{HS} 801 \mathrm{in}$.

Prepare this ppt for counting as desired.

Romarks: Seo Sandell (Colorimotrio Dotermination of Traces of tals)for further information on the extraction of Co from thiocyanate sol'ns wh th $8 / 19 / 49$ othyl other - amyl alcohol. 


\section{CHEITCAL SEPARATIONS}

Eloment soparated: Cobalt

Target matorial: $\mathrm{Cu}, \mathrm{Nl}_{1}$

Typo of bbdt: Neutrons, deutorons - 184" For calutron soparation
Proceduro by: R. C. Lilly

Time for sep'n: 4 hours

Equipment roquired: Boakers, funnols, ohlorination apparatus.

Yiold: $\sim 90 \%$

Degreo of purifiontion: Faotor of 100

Advantagos: Separation of Co from largc amounts of $\mathrm{Cu}$ and $\mathrm{Ni}$.

Procedure: it and $B$ have stops $2-8$ in common.

A. Cobalt from $\mathrm{Cu}(10 \mathrm{gms})+$ noutrons - $184^{\prime \prime}$

(1) Dissolvo $\mathrm{Cu}$ target in 50-100 ml of hot $6 \mathrm{~N} \mathrm{HCl}$ coritaining $5 \mathrm{ml}$ of $30 \% \mathrm{H}_{2} \mathrm{O}_{2}$. Boil off oxcess $\mathrm{H}_{2} \mathrm{O}_{2}$ añd add 25-50 mp Co and 5 me Ni as the chlorido sol'ns. Diluto the samplo to $\sim 1$ litor and add $\mathrm{NH}_{4} \mathrm{OH}$ until the sol'n is neutral or vory slightly aoidic.

B. Cobalt from Ni (1-2 gms) + doutorons - 184"

(1) Dissolvo $\mathrm{Ni}$ target in tho loast possjblo rolume of oono. $\mathrm{HNO}_{3}$. Convert nitrates to chlorides by adding suocossivo portions of cono HCl and taking to a low volumo. sidd $25-50 \mathrm{mg}$ Co and $75 \mathrm{mg}$ Cu as the ohlorido sol'ns. Diluto the samplo to $\sim 500 \mathrm{ml}$ and add $\mathrm{NH}_{4} \mathrm{OH}$ until the sol'n is neutral or very slightly acidic.

In oach of the abovo casos, continuo as follows:

(2) Add oono. $\mathrm{NH}_{4} \mathrm{HSO}_{3}$ sol'n., 1 ml at a timo, until all of the $\mathrm{Cu}$ is reduood (As shown by the lack of any localized blue color whon a fow drops of cono. $\mathrm{NH}_{4} \mathrm{aH}$ a ro addod). Add solid $\mathrm{NH}_{4} \mathrm{SCN}$ dis solved in a small amount of $\mathrm{H}_{2} \mathrm{O}$ until ppt'n is complote.

(3) Coagulate tho CuSCN ppt by heating and filtor it through a double tinioknoss of $\frac{17}{42}$ Thatman papor in a largo glass funnol. Disoard tho ppt.

(4) Boil the filtrite to oxpel $\mathrm{SO}_{2}$ and then add $3 \mathrm{ml}$ of cono $\mathrm{BCl}$ per $100 \mathrm{ml}$ of volume.

(5) Add a froshly preparod hot $30 l^{\text {'n }}$ of alpha-nitroso-bota-naphthol, made by dissolving 10 gms of the salt in $100 \mathrm{ml}$ of $50 \%$ acctio aoid, as long as a ppt is producod.

(6) Filter the ppt through retontive papor. Wash it well with warm $6 \mathrm{~N} \mathrm{HCl,} \mathrm{and} \mathrm{thon} \mathrm{with} \mathrm{warm} \mathrm{H}_{2} \mathrm{O}$ until froc from acid. Ignito the ppt until all of the popor is burned off. 
(7) Dissolvo tho $\mathrm{COO}$ in $\mathrm{HCl}$ c.nd add $100 \mathrm{mg} \mathrm{Cu}$ and $25 \mathrm{mg} \mathrm{NI}$ as the ohioride sol'ns. Adjust the noidity as in stop (1) and repont stops (2) through (6) abovo.

(8) Convart this $\mathrm{CoO}$ to $\mathrm{CoCl}_{2}$ by treating it with anhydrous $\mathrm{Cl}_{2}$ at $650^{\circ} \mathrm{C}$ for 30 minutos.

(If dosired, part of the CoO in stop (7) may bo dissolvod in HCI and a cobalt fraotion purifiod still furthor by adding $\mathrm{Cu}$ and $\mathrm{NI}$ hold-back carriors and folloring tho procodure for co from $\mathrm{NI}$ targots, No. 27-5.)

Remarks :

The abovo proooduro was dosigrod for proparing a samplo for analysis in tho calutron. In oaso a smallor spoctrograph is to bo used, tho amount and final form of the Co may nood ohanging.

Soo Scott (Std. Heth. Chom. Anal.) for further informition on tho ppt'n of co by al pha-nitroso-bota-napthol.

\section{$8 / 19 / 49$}

P-18-233 
CHEMI CAL SEPARA TIONS

Eloment separated: Cobalt

Targot materiol: $\mathrm{Ni}$ (ssparatod isotopos)

Type of bbdt: Protons - 37" and 60" doutcrons - $60 "$

Yiold: $N$ 90\%

Dogroo of purification: Factor of 5

Advantagos: spood

Procoduro:

(1) Dissolvo $\mathrm{Ni}$ foil, woighing $3-5 \mathrm{mg} .$, in a $10 \mathrm{ml}$ boakcr containing

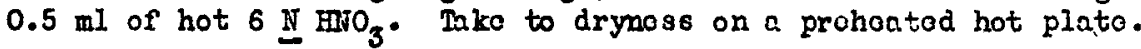

(2) Add 3-4 drops of hot cone ECl and take to drymoss. Ropoat.

(3) Add $2 \mathrm{mg} C 00$ the ohlorido sol'r and warm slightly. Transfor to a $50 \mathrm{ml}$ soparatory fumol and diluto to $10 \mathrm{ml}$ with $\mathrm{H}_{2} \mathrm{O}$.

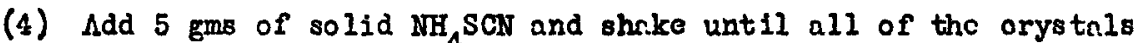
arc dissolvod. Extrot co from this sol'n by shakdng with an oqual volumo of ethyl othor-amyl alcohol (1:1).

(5) Draw off tho $\mathrm{H}_{\mathrm{O}} \mathrm{O}$ layor from this extraotion into a scoond $50 \mathrm{ml}$ soparatory funficl, discarding tho fow drops of mixod sol'ns which roma in in tho stopcock.

(Tho $\mathrm{Ni}$ is containcd in tho $\mathrm{B}_{2} \mathrm{O}$ layor and is workod up separatoly as doscribed in the prooodure for Hi from $\mathrm{Ni}$ targots, No. 28-6).

(6) Add $10 \mathrm{ml}$ of $6 \mathrm{~N} \mathrm{MH}_{\mathrm{A}} \mathrm{OH}$ to tho organic layer in the first soparatory funnel to dostroy the oomplex and reoxtrnot tho Co.

(7) Draw off the smoniacal layor into a small bookor, hoat to boiling, and ppt CoS by adding $\mathrm{MH}_{4} \mathrm{HS}$ sol'n. Proparo this ppt for counting as dosirod.

\section{Remarks:}

Sco sandell (Colorimetrio Determination of Traocs of Motals) for further information on the cxtrcotion of Co from thiocyanato solins with othyl othor - smyl alcohol. If timo allows, purification from cu may bo obtainod by adding 2-3 mg $\mathrm{Cu}$ as tho ohlorido sol'n in stop (3) and ppting CuscN as outlinod in the procoduro for Cu from Ni targits. (No. 29-5). Filtor off tho CuSCN, colloct the filtrato in $50 \mathrm{ml}$ separatory funnol, and procoed with stop (4) abovo.

\section{$8 / 19 / 49$}

$P=18-230$ 
CHEIITCAL TEPARATIOISS

Element soparatod: Cobclt

Targot matorial: Coppor foils ( $\sim 3 \in \mathrm{Cu}$ )

Type of bbdt: $60^{\prime \prime}$ or 184" deuterons

Prooodurc by: Stowart-Softky

Time for sop'n: 4-6 hrs for 12 foils

Equipmont roquirod: $100 \mathrm{ml}$ bcakors, oontrifugo conos, filtor funnc is, sep. funnols

Yield: $80-100 \%$

Decroo of purification: $10^{5}$ from $\mathrm{Cu}$, Zn activitios

Advantages: Can be usod to suparate Co from oopper in a large number of somplos simultanoously (o.E. for oxcitation functions)

Proooduro:

(1) Dissolve coppor foil in $6 \mathrm{~N}$ HCl and a fow drops of $30 \% \mathrm{H}_{2} \mathrm{O}_{2}$. Boil off the poroxide. Idd $2 \mathrm{mE}$ Fo, $\mathrm{Zn}$ and Co carrior as chioridos.

(2) Precipitato $\mathrm{Fo}(\mathrm{OH})_{3}$ with oxcoss $\mathrm{IH}_{4} \mathrm{OH}$, centrifuge and pour off supernatant. Dissolve procipitato in HCl and repest. Add 2nd supernatant to the original.

(3) Hise solution about $\mathrm{O}_{1}{ }^{1} \mathrm{~N}$ with $\mathrm{HCl}$. Add a fow drops of $\mathrm{NH}_{4} \mathrm{HSO}_{3}$ to reduco $\mathrm{Cu}^{+2}$ to $\mathrm{Cu}^{+1}$ (shown by dooolorizod or pale yollotit solution). 'iarm to noar boiling. Add IIE SCN crystals until no further precipitation of cuscr takes placo. Lat sittle for 15 minutes. Filter through that tman i"t2 filtcr papor directly into a soparatory funnel. Vhsh precipitato vith a $1 \%$ solution of $\mathrm{NH}_{4} \mathrm{SCN}$ containing a littlo $\mathrm{NH}_{4} \mathrm{HSO}_{3}$.

(4) Add $5 \mathrm{~g} \mathrm{NH} \mathrm{SCN}$ to the solution in the separatory funnel and extract $\left(\mathrm{NH}_{4}\right)_{2} \mathrm{Co}(\mathrm{SCN})_{4}$ wi th a $1: 1$ amyl alcohol-diothyl other solution. Ilde $2 \mathrm{ml}$ conc. $\mathrm{HCl}$ and $1 \mathrm{~g} \mathrm{NH}_{4} \mathrm{SCN}$ and ropeat extraction until solvont layer is colorloss (2-3 oxtractions usually suffioiont). Ro-cxtract cobalt from the combinod solvont layors with $6 \mathrm{~N}^{\mathrm{NH}} \mathrm{OH}_{4}$.

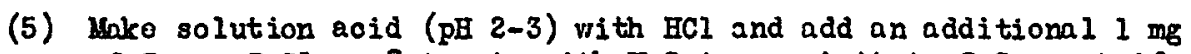
of $\mathrm{Zn}$ as $\mathrm{ZnCl}_{2}$. Saturato with $\mathrm{H}_{2} \mathrm{~S}$ to prooipitato $\mathrm{ZnS}$, oontrifugo and decant supernatant into another cono. Unko slifhtly ammoniacal and warm to coagulato CoS precipitato.

Romarks :

It was found thet $\mathrm{Zn}$ extracted partially from the satemted thiocyanato solution with tho aloohol-cthir mixture.

$8 / 24 / 49$ 
CHEMICAL SIPARATIONS

Elemont separated: Cobalt.

Target matoriel: Copper foils (2-3 g Cu)

Type of bbdt: $50^{\prime \prime}$ or 184 " deuterons
Procedure by: Stemart-Softky

Time for sepin: $4-6$ hrs for 12 foils

Equipmont required: Filtor funno is, boakors

Yield: $\sim$. $0 \%$

Dogroo of purification: $10^{6}$ from $\mathrm{Cu}$

Advantagcs: Can bo used to soparato Co from coppor in a largo number of samples simultancousiy (o.g. for excitation functions.)

Procedure:

(1) Dissolvo copper in minimum dilute $\mathrm{EC}_{1}+$ a few drops of $30 \% \mathrm{H}_{2} \mathrm{O}_{2}$. Boil off peroxido. Add 2 me Fo and Co carriors as chlorido.

(2) Precipitato $\mathrm{Fe}(\mathrm{OH})_{3}$ with excess $\mathrm{NH}_{4} \mathrm{OH}$. Filter and wash with $\mathrm{NH}_{4}$ OH (dilute).

(3) Acidify filtrate to about $0.1 \mathrm{~N} \mathrm{HCl}$, add a fow drops of $\mathrm{NH}_{4} \mathrm{HSO}_{3}$ to reduce $\mathrm{Cu}^{+2}$ to $\mathrm{Cu}^{+}$(docolorizod solution) and warm to noar boiling. $\Lambda$ dd $\mathrm{NH}_{4} \mathrm{SCN}$ crystals until no further precipitation of CuscN takes placo. Let sottle for 15 minutos. Filtor through "l-42 filtcr paper. Tash precipitate with a $1 \%$ solution of $\mathrm{NH}_{4} \mathrm{SCN}$.

(4) Idd sufficiont oono $\mathrm{BCl}$ to filtrite to mako about $1 \mathrm{~N}$ acid and heat to near boiling. Add $5-10 \mathrm{ml}$ of a froshly propared solution

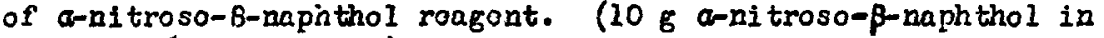
$100 \mathrm{ml} 50 \%$ acetio acid). Lot stand 30 minutes to insuro complete prooipitation of cobalt. 
CHEIIICAL SEPARATIOHS

Eloment separatod: Niokel

Target material: As

Type of bbdt: $190 \mathrm{Kov} \mathrm{D^{+ }}$

Yield: $95 \%$

Degree of purifioation: faotor of $\sim_{10^{3}}$
Prooodure by: H. Hopkins, Jr. Time for sep'n: 45 min. Equipment requirod: standard

Prooodure:

(1) Dissolvo As in minimum $\mathrm{HNO}_{3}+\mathrm{HCl}$, add $2 \mathrm{mg}$ So, Ge carriers, and $6 \mathrm{~m}_{\mathrm{G}} \mathrm{N}$.

(2) Add $\mathrm{KH}_{4} \mathrm{OH}$ to alkaline and pass in $\mathrm{H}_{2} \mathrm{~S}$ rapidly. Centrifuge and wash Jis with $\mathrm{H}_{2} \mathrm{O}$.

(3) Dissolve with cono. $\mathrm{HCl}$ and roppt from $\mathrm{NH}_{4} \mathrm{OH}$.

(4) Dissolvo in minimum oono. $\mathrm{HCl}$, boil out $\mathrm{H}_{2} \mathrm{~S}$, add carriors below Ge, dilute to $10 \mathrm{ml}$ and adjust $\mathrm{pH}$ to $\sim 3$ with Bhlc.

(5) Add dimethyl glyoxime solution until precipitation is oomplete. Centrifugo, dissolve ppt in cono $\mathrm{HNO}_{3}$ and boil.

(6) Dilute to $10 \mathrm{ml}$, make alkaline with $\mathrm{NH}_{4} \mathrm{OH}$ and reppt with dimethyl glyoxime. 
Element separeted: NickeI

Target material: Clg Ii metal

Type of bbdt: 184" all particles
Procedure by: Goockermann

Time for sep'n: 1-2 hrs.

Equipment reguired: Centrifuge, oones, $110^{\circ}$ oven.

Yleld: in $60 \%$

Demree of purifieation: Deoomtamination factor $n 10^{4}$ from fission \& spallation produots.

Advantages: Separates NI in good yield from most elements.

Procedure:

(1) To aliquot of $\mathrm{HWO}_{3}$ soln of target, add $10 \mathrm{mg} \mathrm{Ni}$, make neutral, 2dd $5 \mathrm{ml} 1 \%$ dimothylglyoximo in aloohol, wash with $\mathrm{H}_{2} \mathrm{O}$ and $\mathrm{E}$ tOH. (2) Dissolve $\mathrm{HI} \mathrm{d}-\mathrm{m}-\mathrm{g}$ in $1 \mathrm{ml}$ cone. $\mathrm{H}_{3}$, dilute, \& soav twioe with
CuS.

(3) Scav three times with PdS.

(4) Scav with $\mathrm{Sb}_{2} \mathrm{~S}_{3}$

(5) Boil out $\mathrm{H}_{2} \mathrm{~S}$, make basio with $\mathrm{NH}_{3}$, soar twice with $\mathrm{Fe}(\mathrm{OH})_{3}$.

(6) Wike $0.5 \mathrm{~N}$ in $\mathrm{HCl}$ \& scav with $\mathrm{Pd} d-\mathrm{m}-\mathrm{g}$.

(7) Neutralize supn \& ppt Ni d-m-E.

(8) Dissolve in oono $\mathrm{BNO}_{3}$, reppt $\mathrm{Ni} d-\mathrm{m}-\mathrm{G}$, filter, wash with $\mathrm{H}_{2} \mathrm{O}$ \& Itof, dry $10 \mathrm{~min}$ at II0 $\mathrm{C}$. Weigh as Ni d-m-g (29.4 ms per $10 \mathrm{mg}$ Ni).

Remarks: Desipned to purify a little Mi from a lot of aotivity spread over the periodio table. A few mg of oarrier are used in the scarenges.

$7 . / 6 / 49$

F-18-39 


\section{CHEMICAL SEPARATIONS}

Element separatod: Nickel

Proceduro by: Batzel

Target material: Copper

Time for sep'n: 40 min.

Type of bbdt: $\quad 111-184 " \& 60^{\prime \prime}$

Equipment required: Standard

Yield: $70 \%$

Degree of purification: At least factor of 100 from other activities.

Advantages: Quantitative and specific for this region.

Procedure :

(1) Dissolve copper in minimum amount of oonoentrated nitric acid. Boil to drymoss. Add $5 \mathrm{mg}$ of $\mathrm{N1}$ and 1-2 me of holdback carriers for other elcments $\mathrm{zn}$ and below. Remove copper as sulfido from IN $\mathrm{HCl}$, and wash preoipitate with IN $\mathrm{HCl}$ saturated with $\mathrm{H}_{2} \mathrm{~S}$.

(2) Boil supernate to remove $\mathrm{H}_{2} \mathrm{~S}$. Neutralize with $\mathrm{NH}_{4} \mathrm{OH}$ and make slightly acid with aootio kcid. Add $1 \%$ alooholio solution of dimethyl-glyoxime (2 ml.). Centrifuge and wash the preoipitate twice with 3 oo wajer containing $2-3$ drops of aoetio aoid.

(3) Dissolve the preoipitato in conoentrated $\mathrm{HCl}$ and again add 1-2 mo of holdbaok carriers for other elemonts. Add $\mathrm{NH}_{4}$ OH to neutrallze make slightly aoid with aoetio to reprecipitate.

(1) Weigh as tho $\mathrm{NI} \mathrm{-} \mathrm{dmg.}$

Remarks :

Reference: Scott's Standard Methods of Chemioal Analysis, Volume I, page 619.

$7 / 27 / 49$

P-18- 80 
CEEMTCAL SEPARATIONS

Elemont separatod: Nickol

Proccdure by: Stowart-Softigy

Targat matorial; Coppor folls (300-500 mg Cu.) Timo for sop'n: 3-4 hrs. for 12 samplos

Typo of bbdt: 60" or 184" dcuterons

Equipment requirod: boakors, fil tor funnels

\section{Yicldi in 100\%}

Dogroo of purificatign: Complote separation of $\mathrm{NI}$ from $\mathrm{Zn}, \mathrm{Cu}, \mathrm{Fo}, \mathrm{Co}$, in factor of $n 10^{6}$.

Advantages, Rapid mothod by which many samplos oan be run simultancously. Good yiold with small amount of carricr.

Proocdure:

(1) Dissolve oopper in $6 \mathrm{~N} \mathrm{HCl}+$ a fow drops of $30 \% \mathrm{H}_{2} \mathrm{O}_{2}$ and boil off oxcoss peroxidc. Add $0.5 \mathrm{mg}-1 \mathrm{mg}$ Ni oarricr as ohloride.

(2) Neutralizo with $\mathrm{MH}_{\mathrm{H}}$ Of and make slightly aoid with $\mathrm{HCl}$. Add $\mathrm{NH}_{4} \mathrm{HSO}_{3}$ to reduce $\mathrm{Cu}^{\text {th }}$ to $\mathrm{Cu}$ (only $1-2 \mathrm{ml}$ nocessary) and boil off oxcess $\mathrm{SO}_{2} \cdot$

(3) Procipitate cuscy from the warm solution with a fow orystals of

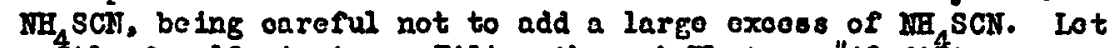
settlc for 10 minutos. Filtor through Thatman ilst fifter papor and wash the proofitate with a $2 \%$ solution of $\mathrm{NH}_{4}$ SCI containing a littlo $\mathrm{NH}_{2} \mathrm{SO}_{3}$.

(4) Adri $1 \mathrm{ml} 50 \%$ tartario acid to the filtrate, make vory sightly ammonioal and warm to noar bolling. Add $1-2 \mathrm{ml} 1 \%$ dimothyl Glyoxime in othanol to prooipitate MIDIG.

(5) Filtor through thatman :"40 filter paper and wash with hot water.

(6) Dissolve prootpitato in d'-2uto HCl and repeat (4) (5) to roduoo 2n \& Co oontamination.

\section{Romarks:}

Stop (1): If solution is made too strongly ammonioal, NIDWG will be incomplotoly proolpitatod.

$7 / 28 /: 9$

P-18- 87 


\section{CHE:ICAL SEPARATIONS}

Element separated: Nickel.

Procedure by: Folger \& Ilicks

Target material:〜 4 g 0 metal foil

Time for sepin: $1-2 \mathrm{hrs}$.

Type of bbct: 184" all high energy particles

Equipmeni required: Centrifuge, cones, $110^{\circ}$ oven, $\mathrm{NH}_{3}$ gas .

Yield: $60 \%$

Depree of purification: Decontamination factor $\sim 10^{4}$ from fission \& spallation produots in $10^{6}$ fror elaments 38-56.

Advantages: Separates $\mathrm{Ni}$ in good yield from most elements.

Prooedure :

(1) To aliquot of target containing un $10 \mathrm{mg} \mathrm{Ni}$ pass in $\mathrm{NH}_{3}$. Csntrifuge and wash twice with sat'd $\mathrm{AgNH}_{3}$. Combine supernatant and washings. (2) Scavenge with $\mathrm{Fe}(\mathrm{OH})_{3}$. Then $\mathrm{Sr}$ and $\mathrm{Ba}$ carbonates and $\mathrm{F}_{\mathrm{C}}(\mathrm{OH})_{3}$
(to clean the sol $\left.\mathrm{In}_{3}\right)^{\text {. }}$

(3) To supernatant add $1-2 \mathrm{ml} 1 \%$ dime thylglyoxime in alcohol. Contrifuge and wash with $\mathrm{H}_{2} \mathrm{O}$.

(4) Dissolve $\mathrm{Ni} \mathrm{d}-\mathrm{m}-\mathrm{g}$ in $1 \mathrm{ml}$ conc. $\mathrm{FNO}_{3}$, dilute to $3 \mathrm{~N}$ and $8 \mathrm{cav}$ twice with Cus.

(5) Dilute to $1 \mathrm{~N}$ and soar three times with PdS.

(6) Scav with $\mathrm{Sb}_{2} \mathrm{~S}_{3}$

(7) Boil out $\mathrm{H}_{2} \mathrm{~S}$, make basic with $\mathrm{NH}_{3}$, scav twice with $\mathrm{F}_{\mathrm{C}}(\mathrm{OH})_{3}$.

(8) Sake $0.5 \mathrm{~N}$ in $\mathrm{HCl}$ \& scav with $\mathrm{Pd} \mathrm{d}-\mathrm{m}-\mathrm{g}$.

(9) Neutralize supn \& ppt $\mathrm{Ni} d-\mathrm{m}-\mathrm{g}$, wash with $\mathrm{H}_{2} \mathrm{O}$.

(10) Dissolve in oono. $\mathrm{HNO}_{3}$ dilute and noutralize, reppt ifl d-m-g, filter, vash with $\mathrm{H}_{2} \mathrm{O}^{3}$, dry 15 min at $110^{\circ} \mathrm{C}$. Weigh as $\mathrm{Ni} \mathrm{d}-\mathrm{m}-\mathrm{g}$ (29.4 mg per $10 \mathrm{mg}$ fil).

RemarkB:

(1) Designed to purify a little $N 1$ from a lot of activity spread over the periodic table. A few $\mathrm{mg}$ of carrier are used in the scavenges.

(2) Where carrier amounts of $\mathrm{Cu}$ and Co are present in the original target soln, it may be necessary to remove these before ppt'ng $\mathrm{Ni}$-dmg since $\mathrm{Co}$ and $\mathrm{Cu}$ form dmg complexes.

(3) N1-dmg is somewhat soluble both in alcohol and in excess d.m.g. There is also a slight solubility in cono $\mathrm{NH}_{4} \mathrm{OH}$. 
Element soparated: Nickel

Target material: $\mathrm{Cu}, \mathrm{NI}$

Type of bbdt: Deutorons - 184"

Neutrons - 60"
Procedure by: R. C. Lilly

Time for sep'n: I hour

Equipment required: Beakers, funnols, fine sintered glass filter, $50 \mathrm{ml}$ separatory funnels (3). $15 \mathrm{ml}$ oentrifuge tubo

Yield: $\sim 90 \%$

Degree of purification: Faotor of 100

Advantages: Purity of N1 product

Prooedure: A, B \& C have stops 4-7 in common.

A. Niokel from N1 (scparated isotopes) + p, d, n - 60"

(1) Dissolve Hi foil, weighing $3-5 \mathrm{me} .$, in a few dro $s 8$ of conc $\mathrm{HNO}_{3}$ and boil off $\mathrm{HNO}_{3}$ with succossive portions of HCl. Add $2 \mathrm{~ms}$ Co. 2 mg Fe and 5 mg $C u$ as the chloride solins.

(2) Dilute to $50 \mathrm{ml}$ with $\mathrm{H}_{2} \mathrm{O}$ and heat to boiling. Ppt $\mathrm{Fo}(\mathrm{OH})_{3}$

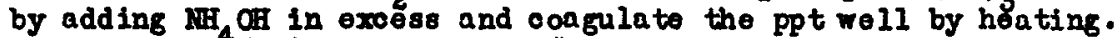
Filter the Fo(OII) 3 pt through $/ 42$ Whatman paper in a glass funnel and wash with a small amount of $1 \% \mathrm{NH}_{4} \mathrm{Cl}$ solin. (The ppt is worked up separatoly as desoribed in the prooodure for Fo from Cu targets, Mo. 26-10). Whe tho filtrato slightly aoldio with BCI. Add oonc $\mathrm{NH}_{4} \mathrm{HSO}_{3}$ sol'n dropwiso until all of the Cu is reduoed (as shown by the laok of any localized blue oolor when a few drops of oone $\mathrm{MH}_{4} \mathrm{OH}$ are added). Add solid $\mathrm{NH}_{4}$ SCN dis solved in a small amount of $\mathrm{H}_{2} \mathrm{O}$ until ppt'n is completo.

(3) Coaguiate tho Cuscr ppt by heating and filtor it through a double thiolness of 742 Thatman xaper in a glass funnel. Discard tho ppt. Boll the flltrate to a volums of $10 \mathrm{ml}$ to expel $\mathrm{SO}_{2}$ and transfer to a $50 \mathrm{ml}$ separatory funnel.

B. Hioke I from Cu $(50-100 \mathrm{mg})+d-184^{\prime \prime}$

(1) Dissolve Cu target in cono. HCl oontaining a few drops of cono. $\mathrm{FHO}_{3}$. Boll off the excess $\mathrm{HNO}_{3} \cdot \Lambda$ dd $2 \mathrm{mg} \mathrm{CO}_{3} 2$ mb $\mathrm{Fe}$, and $2 \mathrm{mg} f \mathrm{f} 28$ the chloride 301 ins.

(2) Diluto to $50 \mathrm{ml}$ with $\mathrm{H}_{2} \mathrm{O}$ and heat to boiling. Ppt $\mathrm{Fo}(\mathrm{OH})_{3}$ by adding $\mathrm{NH}_{4} \mathrm{OH}$ in excess and coagulate the ppt well by heating. Filter the $\mathrm{Fe}(\mathrm{OH})_{3}$ ppt through " 42 Thatman paper in a glass funnel and wash with a $8 \mathrm{mal} i$ amount of $1 \% \mathrm{NH}_{4} \mathrm{Cl}$ sol in. (The ppt is worked up separately as described in the prooedure for Fo from Cu targots, No. 26-10). Wake the filtrate

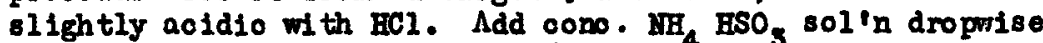
until a.ll of the Cu is roduoed (as shown by the laok of any 
localized bluc color when a few drops of cono $\mathrm{NH}_{4} \mathrm{OH}$ are added). Add solid $\mathrm{NH}_{\mathrm{S}} \mathrm{SCN}$ dissolvod in a small amount of $\mathrm{H}_{2} \mathrm{O}$ until pptin is complete.

(3) Coagula to the CuSCN ppt by heating and filtor it through a double thiokness of 142 that tan paper in a glass funnel. Disoard the ppt. Boil the filtrate to a volume of $10 \mathrm{ml}$ to expol $\mathrm{SO}_{2}$ and transfer to a $50 \mathrm{ml}$ separatory funnel.

c. Wlokol from Cu $(0.1-0.5 \mathrm{gms})+n-60^{\prime \prime}$

(1) Dissolve Cu targot in $10 \mathrm{ml}$ of hot $6 \mathrm{~N}$ HrO ${ }_{3}$ in a small beaker and boil off $\mathrm{BrO}_{3}$ with suocossive porfions of $\mathrm{BCl}$. Add 2 .m Co and 2 Mi as the ohlorido sol'ns.

(2) Add $\mathrm{H}_{2} \mathrm{O}$ and $\mathrm{HCl}$ so as to givo a volume of 25-30 ml with $0.3 \mathrm{H}=0.5 \mathrm{Y}$ HCl. Hoat to boiling and pass in H, $\mathrm{S}$ to ppt Cus. Coagulato the ppt by hoating and filter it through a small fino sintored glass filter. Mash tho pft with a small amount of $\mathrm{H}_{2} \mathrm{O}$ and discard 1 .

(3) Boil the filtrate to a volume of $\sim 10 \mathrm{ml}$ and then transfor it to a $50 \mathrm{ml}$ soparatory funnel.

In all three of the above cases continue as follons:

(4) Add $5 \mathrm{gms}$ of 801 id $\mathrm{NH}_{4} \mathrm{SCM}$ and shake until 1 all of tho orystals are dissolved. Brtract Co from this sol'n by shaking with an oqual rolume of ethyl ether - amyl alcohol (1:1)

(5) Draw off the $\mathrm{H}_{2} \mathrm{O}$ layer from this extraction into a seoond $50 \mathrm{ml}$ separatory funnel, discarding the fow drops of mixed sol'ns which remnin in the stopoock.

(The co is contained in the organio fraotion and is workod up separatoly as desoribod in the prooedure for Co from Cu targets, No. 27-5).

(6) Add $2 \mathrm{mg}$ of Co as the chloride sol'n to the H,O layer in the seoond funnel and reextraot wi th an equal volumo of ethyl etheranyl aloohol $(1: 1)$. Draw off the $\mathrm{H}_{\mathrm{f}} \mathrm{O}$ layer into a $50 \mathrm{ml}$ beaker, boil to a volume of $5 \mathrm{ml}$, and transfor to a $15 \mathrm{ml}$. oontrifugo cono. Disoard the organio layer.

(7) Nabo the sol'n slightly ammoniacal and add $1 \mathrm{ml}$ of $1 \%$ DMG in alcohol to ppt $\mathrm{Ni}$. Contrifuge and discard the supernatant. Nash the ppt with $\mathrm{H}_{2} \mathrm{O}$, centrifuge, and disoard the wash. Propare the ppt for counting as desired.

Remarks: Seo Sandell (Colorimetric Determination of Traces of 10tals) for fur ther information on the extraction of Co from thiocyanate sol'ns with ethyl. other-amyl aloohol. 
CHELITCAL SEPARATIONS

Elomont soparated: Miclool

Proooduro by: R. C. Lilly

Target matorial: Cu(10 goss)

Timo for sop'n: 3 hours

Type of bbdt: Ncutrons - 184"

For colutron s cparation

Equipmont roquired: boakers, funnols, contrifuge cono

Yield: $\sim 90 \%$

Dogroo of puriffeation: Factor of 100.

Advantages: Soparatos $\mathrm{Hi}$ from largo amounts of $\mathrm{Cu}$.

Procoduro:

(1) Dissolvo Cu targot in 50-100 ml of hot $6 \mathrm{~N} \mathrm{HCl} \mathrm{oontaining}$ $5 \mathrm{ml}$ of $30 \% \mathrm{H}_{2} \mathrm{O}_{2}$. Boil off exoess $\mathrm{B}_{2} \mathrm{O}_{2}$ añd add 25-50 mb Co and $6 \mathrm{mg} \mathrm{HI}$ as tho ohlorido sol'ns. 'Dllute tho samplo to $\sim 1$ litor and add $\mathrm{NH}_{4} \mathrm{OH}$ until tho $80 \mathrm{l}$ 'n is neutral or vory slightly acidic.

(2) Add cono. $\mathrm{NH}_{\mathrm{HSO}} 80 \mathrm{l} \mathrm{h}$., I ml at a timo, until all of the Cu is roduced (as shown by the lack of any looalizod bluo color whon a fow drops of oono. $\mathrm{NH}$ OH aro addod). Add solid $\mathrm{NH}_{4} \mathrm{SCN}$ dissolvod in a small amount of $\mathrm{H}_{2} \mathrm{O}$ until ppt in is complote.

(3) Coagulate tho CuSCN ppt by hoating and filtor it through a doublo thiokness of ;"A2 thatman papor in a large glass funnol. Disoard tho ppt.

(4) Boil the filtrate to a volumo of $200 \mathrm{ml}$ and mako tho sol'n slightly - ammoniacal.

(5) Add 1\% DLG in alcohol until no furthor ppt is produood. Add $\mathrm{NHF}_{4} \mathrm{OH}$ until the sol'n is distinotly basio.

(6) Coagulate tho ppt by hoating and thon filtor it through that than papor in a glass funnel. Fash tho ppt thoroughly with warm $\mathrm{H}_{2} \mathrm{O}$. Ignite the ppt until all of the paper is burned off.

(7) Dissolvo tho $\mathrm{N} 1 \mathrm{O}$ in $\mathrm{BCl}$ and add $100 \mathrm{mg} \mathrm{Cu}$ and $10 \mathrm{mg} \mathrm{HI}$ as tho ohlorido sol'ns. Ndjust the aoidity as in stop (1) and repent stops (2)' and (3).

(8) Boil the sol'n to a low volumo and trunsfor to a oontrifugo oono. miko slightly ammoniacal and ppt $\mathrm{Ni}$ with DUG as in stop (5) abovo. Coagulato the ppt in a hot $\mathrm{H}_{3} \mathrm{O}$ bath, oentrifuge, and discard tho supornatant. Proparo tho ppt for oounting as desirod.

Remarks: Tho abovo procoduro wes designed for preparing a samplo for analysis in the oalutron. In oaso a smallor spootrograph is to bo usod, tho anount and final form of the $\mathrm{N}_{1}$ may nood ohanging. 


\section{CEEIIICAL SIFABATIONS}

Element seporated: Copper Prooodure by: H. Eopkins, Jr.

Target material: As Time for sep'n: $3 / 4 \mathrm{hr}$. Type of bbdt: 190 Mev $\mathrm{D}^{+}$ Equipment required: stenderd

Yield:>90\%

Degree of purification: factor of $n 10^{3}$

Prooeduro:

(1) Dissolve As in $\mathrm{HCl}+\mathrm{HNO}_{3}$, evap off $\mathrm{HNO}_{3}$, add $5 \mathrm{mg}$ Cu carrier and $1 \mathrm{mg}$ other holdbacks.

(2) Ppt from $1 \mathrm{NHCl}$ with $\mathrm{H}_{2} \mathrm{~S}$. Wash with $\mathrm{H}_{2} \mathrm{O}$ and treat ppt several times with I I KOH. Washes out As \& $G_{\theta}^{2}$ - discard.

(3) Dissolve remining ppt in minimum cono. $\mathrm{HHO}_{3}$, evap to dryness with HCl.

(4) Dilute to $1 \mathrm{~N} \mathrm{ICl}$, add pinches of solid $\mathrm{Na}_{2} \mathrm{SO}_{3}$ and $\mathrm{NaCNS}$. (5) If the preoipitate is not pure winite add more $\mathrm{Na}_{2} \mathrm{SO}_{3}$. After two
minutes centrifuge.

(6) Dissolve with hot cono. ECl and repeat precipitation.

(7) Teigh as Cu SCH.

Remarks: Holdbacks added Cr through Sc except As \& Cu.

$6 / 28 / 49$

P-18-34 


$$
29-2
$$

CHEIITCAL SEPARATIONS

Elemont separated: Copper

Procedure by: Batzel

Targot material: Coppor

Time for sep'n: $40 \mathrm{~m}=\mathrm{n}$.

Type of bbdt: 60" 184",linear

acelerator - all particles

Equipmont requirod: standord

Yield: $80 \%$

Degreo of purification: factor of $\sim 10^{3}$

Procedure?

(1) Add holdtack carriers for the nocessary elemorts. Dissolvo the copper in as littlo $\mathrm{HCl}$ os possible adding $\mathrm{H}_{2} \mathrm{O}_{2}$ to speed up the solution.

(2) Maze 1 in in $\mathrm{HCl}$. Reciuce the $\mathrm{Cu}^{++}$to $\mathrm{Cu}^{+}$with $\mathrm{Na}_{2} \mathrm{SO}_{3}, \operatorname{cool}$ and add NaCNS uñtil prccipitation is complote.

(3) Centrifuge and wash the precipitate with cold water.

(4) The creojpitate can be dissolved in concontrated $\mathrm{HFO}_{3}$ or $\mathrm{HCl}$.

(5) Reprecipitation can be accomplished by diluting to $1 \mathrm{~N}$, reducing and repreoifitating wi th thiocyanate.

\section{Remarks:}

(1) Copper can also be precipitated os the sulfide from $0.5 \mathrm{~N}$ to $1.0 \mathrm{~N}$ acid solution, and the precipitate dissolved in fuming in $\mathrm{HNO}_{3}$.

(2) A drop of rotting agent will provent the tendency of the precipitate to oroep.

(3) In redissoiving care must be taleen since the ovelution of gas is profuse.

(4) Three precipitgtions of the cu are enough to give a decontamination fuc tor of $\sim 10^{8}$.

$$
\begin{aligned}
& 7 / 6 / 40 \\
& P-1.8=13
\end{aligned}
$$




\section{CHELTCAL SERARATIONS}

Element separatod: Copper

Procedure by: Goookermam

Target material: U I B Bi motal

Time for sep'n: 1-2 hrs.

Typo of bbdt. $184^{\text {n }}$ all partioles

Equipment required: Centrifuge, cones, $110^{\circ}$ oven.

Yield: in $60 \%$

Degree of purifioation: Deoontamination faotor $\wedge 10^{4}$ from fissi on \& spallation produots.

Advantages: Good yield of Cu purifled from all other elomente.

Prooedure:

(1) To aliquot of $\mathrm{HNO}_{3} 80 \mathrm{ln}$ of target, add $10 \mathrm{mg} \mathrm{Cu}$, make basio with $\mathrm{HH}_{3}$, contrifuge out $\mathrm{Bi}(\mathrm{OH})_{3}$ \&oavenge with $\mathrm{Fe}(\mathrm{OH})_{3}$ and $\mathrm{BaCO}_{3}$ $\left(\mathrm{add} \mathrm{K}_{2} \mathrm{CO}_{3}\right)$.

(2) Mke supn $0.5 \mathrm{~N}$ in HCl. Bubble in $\mathrm{SO}_{2}$, add KCrs unt1l CuCWS ppts (slight excess)

(3) Dissolve Cu CNS in $\mathrm{WNO}_{3}$ \& make neutral. Add KCH \& soavengo with CdS.

(4) Acidify \& boil off HCN (cautionl), add Sr \& Y holdbaok, ppt CuS from 3N BCl.

(5) Dissolve in $\mathrm{HNO}_{3}$, add $\mathrm{XCl}$ \& destroy $\mathrm{FHO}_{3}$. Dilute to 0.5 I HCI \& soavenge twioe with AgCl.

(6) Ppt CuCNS from supn, filter, wash with $\mathrm{H}_{2} \mathrm{O} \& \mathrm{EtOH}$, dry 15 min. at $110^{\circ} \mathrm{C}$. Woigh as CuCls (19.2 $\mathrm{mg}$ per $10 \mathrm{mg}^{2} \mathrm{Cu}$ ).

Remarks: Soavenges made with $1-5$ of oarrier. 


\section{CHEMICAL SEPARATIONS}

Eloment soparated: Copper

Target material: M4 g D mol foil

Typo of bbdt. 184" all high onergy partioles
Procodure by: Folger \& Hicles Timo for sop'n: $1-2 \mathrm{hrs}$.

Equipment required: Centrifuge, cones, $110^{\circ}$ oven.

Yiold: U $60 \%$

Degroe of purification: Decontamination factor $\backsim 10^{4}$ from fission \& sallation produots. On $10^{6}$ from olcments $38-56$.

Advantages: Good yiold of $\mathrm{Cu}_{u}$ purifiod from all other elemonts.

Procodure:

(1) To aliquot of $\mathrm{HNO}_{3}$ or HCl soln of target, add $10 \mathrm{mg} \mathrm{Cu}$, make basio with $\mathrm{NH}_{3}$, oentriflige out $\mathrm{Bi}(\mathrm{OH})_{3}$ \& scavengo with $\mathrm{Fe}(\mathrm{OH})_{3}$ and $\mathrm{BaCO}_{3}$, $\mathrm{SrCO}_{3}\left(\mathrm{ddd} \mathrm{K}_{2} \mathrm{CO}_{3}\right)$.

(2) The supn $0.5 \mathrm{~N}$ in HCl. Bubble in $\mathrm{SO}_{2}$, add KCNS until CuCNS ppts (slicht cxcoss)

(3) Dissolvo $\mathrm{Cu}$ CNS in $\mathrm{HHO}_{3}$ \& makc noutral. Ldd KCN \& scavenge with CdS, ${ }^{A_{2}} \mathrm{~S}_{3}$ and $\mathrm{TOS}_{2}$.

(4) Acidify \& boil off HCN (cautionl), add Sr, La \& Y holdbacks, ppt Cus from $3 \mathrm{~N} \mathrm{HCl}$.

(5) Dissolve in minimum $\mathrm{HWO}_{3}$. Diluto to $0.5 \mathrm{~N}^{+}$\& scavongo trico with AgCl. (Bolling helps coagulato $\mathrm{AgCl}$ ).

(6) Ppt CuCNs from suph, filtor, wash with $\mathrm{H}_{2} \mathrm{O}$ a EtOH, dry 15 min. at $110^{\circ} \mathrm{C}$. Teigh as Cucrs (19.2 $\mathrm{mg}$ per $10 \mathrm{mg} \mathrm{Cu}$ ).

Romarks: Scavenges mado with $1-2$ mg carrier.

$7 / 28 / 49$

P-18-95 
CFEMIC $\angle L$ STPARATIONS

Elomant separatod: Coppor

Target material: Ni (soparated isotopos)

Typo of bbdt: Protons - $37^{\prime \prime}$ and $60^{\prime \prime}$

Douterons - 60"
Procoduro by: R. C. Lilly

Timo for sop'n: 4-5 minutes

Equipmont roquirod: Sm 11 bookers, Hirsoh funnol

Yicld: $50-75 \%$

Dogroo of purification: Faotor of 5

idventares: spood

Procedure:

(1) Dissolvo $\mathrm{NI}$ foil, woighing 3-5 mg., in a $10 \mathrm{ml}$ boakor containing $0.5 \mathrm{ml}$ of hot 6 N $\mathrm{HrO}_{3}$. Take to drymess on a prohoatod hot plate.

(2) Add 3-4 drops of hot conc $\mathrm{HCl}$ and take to drynoss. Ropont.

(3) Idd tho following in succossion, warming aftor each addition: $2 \mathrm{mg} C u$ and $2 \mathrm{mg} C_{0}$ as $2 \mathrm{ml}$ of tho ohlorido sol'ms; $0.5 \mathrm{ml}$ cono $\mathrm{NH}_{4} \mathrm{BSO}_{3}$ sol'n.; and $0.5 \mathrm{ml} 10 \% \mathrm{NH}_{4} \mathrm{SCN}$ sol'n.

(4) Stir and warm slightly. Filtor the samplo through a 1 th that than filter paper diso held in a Gooch oruciblo or Hirsoh funnol and prowot with a fow drops of $0.1 \underline{N} \mathrm{NH}_{4} \mathrm{SCN}-0.1 \mathrm{~N} \mathrm{NH}_{4} \mathrm{HSO}_{3}$ wash sol'n.

(5) Wash with a small amount of $0.1 \mathrm{~N} \mathrm{NH}_{4} \mathrm{SCN}-0.1 \mathrm{~N} \mathrm{NH}_{4} \mathrm{HSO}_{3}$ = wash sol'n followed by a fow drops of acotone. Nount for counting.

$8 / 19 / 49$ 
CEELICAL SEPARATIONS

Element separated: zino

Target matorial: 18 Bi notal

Type of bbdt: $184^{\prime \prime}$ bbdt all particlos
Prooeduro by: Goockermann

Time for sep'n: in $1 \mathrm{hr}$.

Bquipment required, centrifuge, oones, ice, vacuum dessioator

Yiold: in $70 \%$

Dogroo of purification: lio deteotablo contamination from other fission and spellation produots.

Advantages: Good yield of puro zino.

Procodure:

(1) To allquot of nitrio acid soln of $\mathrm{Bi}$, add $10 \mathrm{mg} \mathrm{Zn}, \mathrm{l} \mathrm{ml} \mathrm{sat.} \mathrm{H}_{2} \mathrm{C}_{2} \mathrm{O}_{4}$, and mnke $1 \mathrm{~N}$ in $\mathrm{ENO}_{3}(10-25 \mathrm{ml})$. CoOl in 100 bath, add $3 \mathrm{ml} z_{\mathrm{a}}$ roagint

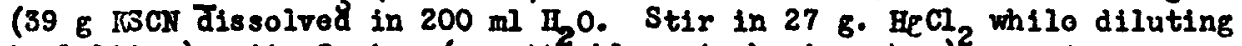
to 1 iitor), stir 6 min. (soratoh glass to bogin pptn.) ${ }^{2}$

(2) Dissolvo $\mathrm{ZnHg}\left(\mathrm{SCN}_{4}\right.$ in $5 \mathrm{ml} 2 \mathrm{X} \mathrm{FNO}_{3}$ and dilute to $1 \mathrm{ly}$. Add $1 \mathrm{ml}$ sat $\mathrm{H}_{2} \mathrm{C}_{2} \mathrm{O}_{4}$ and $3 \mathrm{ml} 2 \mathrm{n}^{4}$ reagent.

(3) Repoat (2).

(4) Dissolve ppt in $2 \mathrm{~N} \mathrm{HNO}_{3}$, dilute to $1 \mathrm{~N}$, and ppt HgS. Neutralize supn to $0.3 \mathrm{~N} \mathrm{HNO}_{3}{ }^{-}{ }^{-1}$ th $^{3} \mathrm{NaOH}$ and $\mathrm{ppt} \mathrm{BI}_{2} \mathrm{~S}_{3}$ (5 mg Bi) three times.

(5) Jake 1 MI in $\mathrm{NH}_{4} \mathrm{Ao}$ and ppt $2 \mathrm{nS}$.

(6) Dissolve ppt in $5 \mathrm{ml}$ cone $\mathrm{HBr}$, evap to dryness sovoral times, take up in $10 \mathrm{ml} \mathrm{C.5} \mathrm{N} \mathrm{NaOH}$, add $1 \mathrm{ml} 2 \mathrm{Na}_{2} \mathrm{CO}_{3} \cdot \mathrm{Ppt} \mathrm{Fo}(\mathrm{OH})_{3}(2 \mathrm{mg})$ and $\mathrm{BaCO}_{3}$ (5 mg) thrö times frem hot sōln.

(7) Add $\mathrm{BCl}$ to make $1 \mathrm{~N}$ and $\mathrm{I} \mathrm{ml}$ sat $\mathrm{H}_{2} \mathrm{C}_{2} \mathrm{O}_{4}$. Add $3 \mathrm{ml} \mathrm{Zn}$ reagent to cold soln, stir $3 \mathrm{~min}$. Filter, wash threa times with $5 \mathrm{ml}$ absolute $\mathrm{EtOH}$ and three times with $5 \mathrm{ml}$ ether, dry $7 \mathrm{~min}$ in racuum dessioator. Woigh as $\mathrm{ZnHg}(\mathrm{SCN})_{4}(76.2 \mathrm{mg}$ por $10 \mathrm{mgZn})$.

Remarks: Standardizo carrior as $2 \mathrm{nHz}(\mathrm{SCN})_{4}$ also. Final ppt poor if radiations soft beceuse of large self-absorption correction required.

$6 / 27 / 49$

P-18-28 


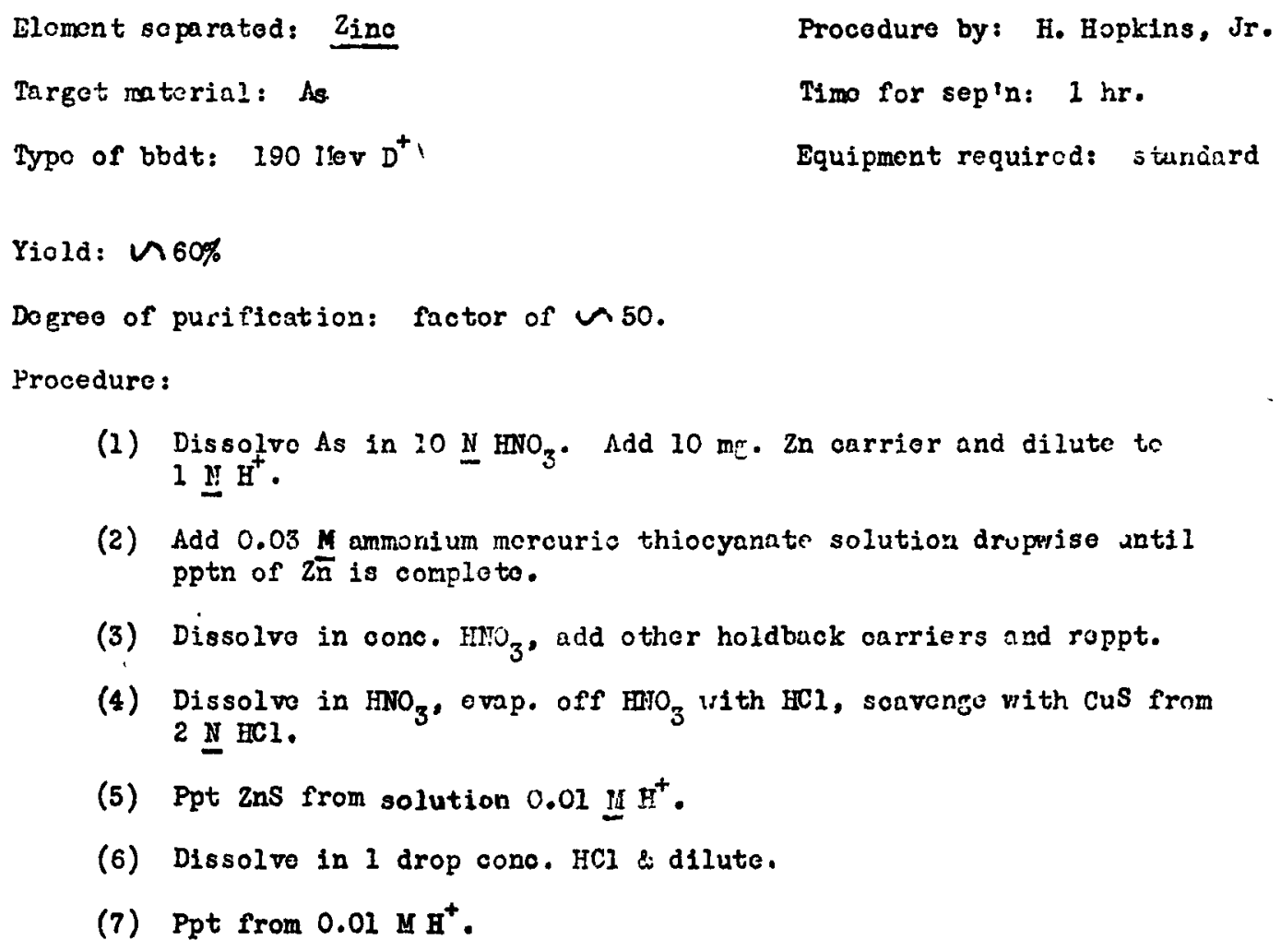

(1) Dissolvo As in $20 \mathrm{~N} \mathrm{HNO}_{3}$. Add $10 \mathrm{mc}$. $2 \mathrm{n}$ oarrior and dilute to 1 IN $\mathrm{H}^{+}$.

(2) Add $0.03 \mathrm{M}$ ammonium mercurie thiocyanate solution drupwise antil pptn of $2 \bar{n}$ is complete.

(3) Dissolvo in cone. $\mathrm{mlO}_{3}$, add other holdback oarriers and roppt.

(4) Dissolve in $\mathrm{HNO}_{3}$, evap. off $\mathrm{HHO}_{3}$ with $\mathrm{HCl}$, scavenge with CuS from 2 N $\mathrm{HCl}$.

(5) Ppt 2 nS from solution $0.0114 \mathrm{~B}^{+}$.

(6) Dissolvo in 1 drop cone. HCl \& dilute.

(7) Ppt from $0.01 \mathrm{M} \mathrm{H}^{+}$.

Remarke: Holdbaok carriors that oan be added Cr thru Se excopt As \& $2 n$. 
Element separated: تinc

Target material: copper

Type of bbdt: all particles 184" $\& 60^{\prime \prime}$

Yiold: $60 \%$

Degree of purification: factor of $\mathrm{N} \mathrm{O}^{3}$.
Procedure by: Batzel

Time for sopin: $40 \mathrm{~min}$.

Equipment requirod: Standard

Proceduro :

(1) The copper is dissolved in concentrated $\mathrm{HWO}_{3}$ or $\mathrm{HCl}$ and $\mathrm{H}_{2} \mathrm{O}_{2}$ to speed up solution. Five $m g$ of $\mathrm{Zn}$ and 1 or $2 \mathrm{me}$ of holdback corriers for tho necessary eloments are added.

(2) Tho coppor is removed as the sulfide from a $1 \mathrm{~N}$ acid solution, $\mathrm{NH}_{4} \mathrm{OH}$ added to make the soln alkaline and then $\mathrm{H}_{2} \mathrm{~S}$ added to comploto precipitation.

(3) The precipitate is washod with a solution containing a couple of drops of $\mathrm{NH}_{4} \mathrm{OH}$ and saturated with $\mathrm{H}_{2} \mathrm{~S}$.

(4) After centrifugation 2-3 ml. of $5 \mathrm{fr} \mathrm{HCl}$ are added, the precipitato, stirrod well, and the solution centrifuged almost immediately (arter about one minute). The zinc and manganous sulfides aro dissolvod while the nickel and cobalt sulfides aro attacked slow ly.

(5) The supernate is boiled to remove $\mathrm{H}_{2} \mathrm{~S}$ approx $1 \mathrm{ml}$ cone, $\mathrm{NI}_{4} \mathrm{OH}$ added to ncutralize the $\mathrm{HCl}$ and an equal volume $(3,4 \mathrm{cc})$ of conc. HAC added. The solution is hoated almost to boling and saturated with $\mathrm{H}_{2} \mathrm{~S}$ to precipitato tho $\mathrm{Zn}$.

(6) The procipitate is dissolved in $1 \mathrm{~N} \mathrm{HCl} \mathrm{-} \mathrm{the} \mathrm{H}_{2} \mathrm{~S}$ boilod off and 2 Fo holdbaok oarrier added. $\frac{1}{2}$ to 3 pellots of $\mathrm{NaOH}$ are added and the ppt renoved loaving tho in in solution as zincate.

(7) Tho solution is mado $1 \mathrm{~N}$ in $\mathrm{HCl}$ and $z$ ino reagent addod to porform the $f$ inal procipitation.

Remarks:

(1) Tho $\mathrm{Zn}$ roaront is mado from $32 \mathrm{gm} \mathrm{NH}_{4} \mathrm{SCN} \& 27 \mathrm{fm} \mathrm{HECl}$ in $500 \mathrm{ml}$ $\mathrm{H}_{2} \mathrm{O}$. (See Scotts Standard Methods of Chomical Analysis, Vol. I, p.45)

(2) The Zn reagent precipitate can be dissolved in 5-6 $\mathrm{N} \mathrm{HHO}_{3}$.

(3) The $\mathrm{Zn}$ reagent is a satisfactory analytical procedure, but the gravimetric factor should be determined exporimentally.

$7 / 6 / 49$

P-13-36 
CHEMICAL SEPARATIONS

Eloment soparatod: Zino

Targot material: Copper foils (ca $300 \mathrm{mg}$ )

Proooduro by: Stowart-

Timo for sop'n: $1-2 \mathrm{hrs}$. for 12 samples

Type of bbdt: 60" or 184" deutorons

Equipront roquirod: $100 \mathrm{ml}$ boaker $40 \mathrm{ml}$ oentrifugo cono filter funnol 20 mosh aluminum

Yiold: $\quad 80-100 \%$

Degroo of purification: Decontamination by factor of $\mathrm{M}^{4}$ from othor activitios.

rantages: Simplicity. Can be usod to separato $2 n$ from coppor rapidly in a large number of samplos simultanoously (c.g. for excitation functions).

rocedure:

(1) Dissolvo Cu foil in $100 \mathrm{ml}$ boakor with a minimum amount of $6 \mathrm{~N}$ $\mathrm{HNC}_{3}$. Add 2-3 ms $\mathrm{Zn}$ carrier as nitrate or sulfato.

(2) Idd $1 \mathrm{ml}$ cono. $\mathrm{H}_{2} \mathrm{SO}_{4}$ and evaporate to $\mathrm{SO}_{3}$ fumes to remore $\mathrm{HNO}_{3}$.

(3) Dilute to 2-3 $\mathrm{N} \mathrm{H}_{2} \mathrm{SO}_{4}$ and add about $500 \mathrm{mg} 20 \mathrm{mesh}$ aluminum. Boil until all $\mathrm{Cu}^{2}$ is roduced and for about 5 minutes after tho solution appoars to be water-whito. Cool.

(4) Filter through a rapid filter paper and catch filtrato in a $40 \mathrm{ml}$ ocntrifuge cone. Wash $\mathrm{Cu}$ ppt with $0.1 \mathrm{~N}-\mathrm{H}_{2} \mathrm{SO}_{4}$.

(5) Add a drop of methyl orango to the filtrate and adjust to $\mathrm{pH} 2-3$ with $\mathrm{NaOH}$ and di lute $\mathrm{H}_{2} \mathrm{SO}_{4}$.

(6) Saturato with $\mathrm{H}_{\mathrm{S}} \mathrm{S}$ to precipitato $\mathrm{ZnS}$, contrifuge, and docant supornatant. Wash with $0.01 \mathrm{~N}_{2} \mathrm{SO}_{4}$ contalning $\mathrm{H}_{2} \mathrm{~S}$.

(7) Plato ZnS \& oount.

Romarks:

Wethod is dosigned to givo rapid scparation of $\mathrm{Zn}$ from Cu whon doing 6 to 12 samplos simul tancously. Therc is some Cu contamination aftor only one aluminum roduotion, but this is much less than $0.1 \%$ when only 300-500 mg of $\mathrm{Cu}$ is used for the target. Contamination could bo reduced by adding 1-2 mp inort coppor carricr c.s chlorido or sulf to after filtering (step 4) \& procipitating CuS from $1 \mathrm{~N} \mathrm{H}_{2} \mathrm{SO}_{1}$ with $\mathrm{H}_{2} \mathrm{~S}$. After removal, reduco a. idity to $0.1-0.01 \mathrm{~N} \mathrm{H}_{2} \mathrm{SO}_{4}$ \& ppt $\mathrm{ZnS}$.

$7 / 28 / 49$

P-18- 88 
Elomont separated: Zine

Target mtorial: Coppor

Typs of bbdt: $60^{\prime \prime}$ or $184 "$

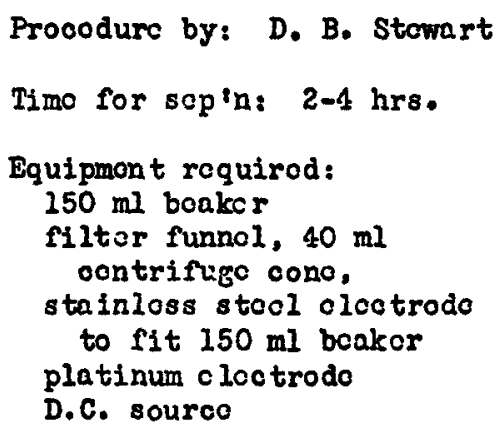

Yicld: $80-100 \%$

Dogrio of purification: Complote separation from ooppor, botter than $10^{6}$.

Advantagos: Only smill amount of carrior nocdod as comparcd to coppor.

(1 $\mathrm{mg} \mathrm{Zn}$ oarrior can be recorercd quantitatively from up to $20 \mathrm{~g} \mathrm{Cu}$ )

Procedurc:

(1) Dicsolvo coppor in $6 \mathrm{WN}$ - HNO 3 and ovaporato off oxcoss acid. Ldd $1 \mathrm{mg} \mathrm{Zn}$ carricr as nitrate and $0.5 \mathrm{ml}$ conc. $\mathrm{H}_{2} \mathrm{SO}_{1}$. Diluto to about $100 \mathrm{ml}$ vith wator.

(2) Elsctrodeposit coppcr on a stainloes stoel cothodo at 2-3 volts, 5-10 ampcros usine a rotating Pt anode. Sot apparatus in an ice bath during tho elootrolysis.

(3) Then solution is wator-white, turn off curront and quickly romovo clectrodos. Evaporato solution to $\mathrm{SO}_{3}$ fumes to removo $\mathrm{HNO}_{3}$. (It may bo noocssary to add a for drops of $\mathrm{H}_{2} \mathrm{SO}_{4}$ ). Diluto to $20 \mathrm{ml}$ (or about $1:-\mathrm{a}_{2} \mathrm{jO}_{4}$ ). Saturato with $\mathrm{H}_{2} \mathrm{~S}^{2}$ to procipitato romining copper.

(4) Filter through thatman :"142 filter paper, wash procipitate with $1 \mathrm{f}$ $\mathrm{H}_{2} \mathrm{SO}_{4}$ containing a little $\mathrm{H}_{2} \mathrm{~S}$. Boil filtrato to expol exooss $\mathrm{H}_{2} \mathrm{~S}$.

(5) Transfor solution to a $40 \mathrm{mI}$ contrifuge cono. Add a drop of mothyl orango indicator and adjust to $\mathrm{pH} 2-3$ with $\mathrm{NhOH}$ and dilute $\mathrm{H}_{2} \mathrm{SO}_{4}$. Saturate with $\mathrm{H}_{2} S$ to precipitate $2 n S$. Contrifuge, decant supe rnatant, and wash with $0.01 \mathrm{~N}_{2} \mathrm{SO}_{4}$ oontaining $\mathrm{H}_{2} \mathrm{~s}$.

Remarks :

(Step 2) Cathodo used was a stainloss stool inner facket for tho boaker with a strip extension for outsjido connoction to the oleotrolysis unit. Exposed surfaco was about $75 \mathrm{~cm}^{2}$. Doposit is not vory smooth at this curront and cooling 18 ncessary.

$7 / 28 / 49$

P-18-123 
Element separatod: 2ino

Tarcet materialin 4 g U netal

Type of bbdt: $184^{\prime \prime}$ bbdt all high energy partioles
Prooedure by: Folger \& Hicles

Time for sep'n: $\sim 2 \mathrm{hr}$.

Equipment required: Centrifuge, cones, ice, $110^{\circ}$ oven

Yield: $70 \%$

Dogroo of purification: No detectable ogntamination from other fission and spallation products - factor of $\sim 10^{5}$ decontsmination.

Procodure :

(I) To aliquot of nitric aoid soln of 0 containing $\sim 10 \mathrm{mg} 2 \mathrm{n}$ add $1 \mathrm{ml}$ sat. $\mathrm{H}_{2} \mathrm{C}_{2} \mathrm{O}_{4}$, and make $1 \mathrm{~N}$ in HNO $_{3}(10-25 \mathrm{ml})$. Cool in ioe bath, add $3 \mathrm{ml} \mathrm{Zn}^{4}$ reagent ( $39 \mathrm{~g}$ KSCN dissolved in $200 \mathrm{ml} \mathrm{H} 0$. Stir in $27 \mathrm{E} \mathrm{BgCl}$, while diluting to 1 liter), stir 5 min. (scratch glass to begin pptn.)

(2) Dissolvo $2 \mathrm{nHg}(\mathrm{SCN})$ in $3 \mathrm{mI} 4 \mathrm{~N} \mathrm{HNO}_{3}$ and dilute to $1 \mathrm{~N}$. Add $1 \mathrm{mI}$ sat. $\mathrm{H}_{2} \mathrm{C}_{2} \mathrm{O}_{4}$ and 3 All $\mathrm{Zn}$ reagenE.

(3) Repoat (2), but so not add $\mathrm{H}_{2} \mathrm{C}_{2} \mathrm{O}_{4}$.

(4) Dissolve ppt in $2 \mathrm{~N} \mathrm{HrO}_{3}$, dilute to $1 \mathrm{~N}$, and ppt $\mathrm{CuS}, \mathrm{Ag}_{2} \mathrm{~S}, \mathrm{SnS}_{2}$, $\mathrm{Sb}_{2} \mathrm{~S}_{3}, \mathrm{Bi}_{2} \mathrm{~s}_{3}$. Repeat using CuS as final scavenge.

(5) Hake 1 $\mathrm{K}$ in $\mathrm{NH}_{4} \mathrm{Ac}$ and ppt $\mathrm{ZnS}$.

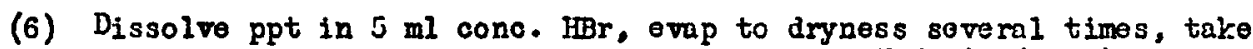
up in $5 \mathrm{ml} \mathrm{N}$ HaOH, add $1 \mathrm{ml} 2 \mathrm{Na}_{2} \mathrm{CO}_{3}$. Ppt $\mathrm{Fe}(\mathrm{OH})_{3}(2 \mathrm{mg})$ and $\mathrm{BaCO}_{3}+\mathrm{Sr}_{3} \mathrm{CO}_{3}$ (2 mg) threo timës from hot soln.

(7) Add HCl to mke $1 \mathrm{~N}$. Add $3 \mathrm{ml} 2 \mathrm{n}$ reagent to cold soln, 8 tir $3 \mathrm{~min}$, filter, wash three times with $5 \mathrm{ml}$ absoluto EtOH and three times with $5 \mathrm{ml}$ other, dry $15 \mathrm{~min}$. in $110^{\circ} \mathrm{C}$ oven. Weigh as $\mathrm{ZnHg}(\mathrm{SCN})_{4}$ (76.2 mg por 10 mg2n).

Remarks: Standardize carrier as $\mathrm{ZnHg}(\mathrm{SCN})_{4}$ also. Final ppt poor if radiations soft because of large self-absorption correction required. 


\section{CHEMICAL SEPARATIONS}

Element separatod: Zino

Target material: Copper

Typo of bbdt: Doutcrons - $60^{\prime \prime}$

Yiold: 100\%
Procoduro by: R. C. Lilly

Time for sepin: 6-8 hours

Equipmont requirod: Pt crapora tine dish, Pt anodo, stirring motor, DC souroo supplying 2-4 amps at $\sim 5$ volts, pH motor, boakors and funnols

Degreo of purification: excellent - at lonst factor of 100 from other activitios proscnt.

Advantagos: Easy method for removing largo anounts of $\mathrm{Cu}$

Procodure:

Tho reight of $\mathrm{Cu}$ used should not excoed 2 gms for the quantitics and rolumes givon bolow. If the amount of $\mathrm{Cu}$ is large, it is advisablo to dissolvo the target and romovo an aliquot.

(1) Dissolve $\mathrm{Cu}_{\mathrm{u}}$ target in $\mathrm{ENO}_{3}$ and tako the sol'n to drynoss.

(2) Redissolve the $\mathrm{Cu}\left(\mathrm{NO}_{3}\right)_{2}$ by warming with $\mathrm{H}_{2} \mathrm{O}$; then add $2 \mathrm{ml}$ cono $\mathrm{HNO}_{3}, 2 \mathrm{ml}$ cono $\mathrm{H}_{2} \mathrm{SO}_{4}$, and $2-5$ mg $\mathrm{Zn}^{2}$ as $\mathrm{ZnSO}_{4} 801 \mathrm{n}$.

(3) Transfor to a Pt onporating dish; the sol'n volumo should bo $\sim 50 \mathrm{ml}$. Jsing a rotating $\mathrm{Pt}$ anode, romovo $\mathrm{Cu}$ by olcetrolyzing for from ono to soveral hours at 2-4 amps and $\sim 5$ volts. Tho sol'n should bocomo colorloss. Pour tho sol'n from tho dish into a beckor; rinso tho $\mathrm{Cu}$ doposit with sovoral small portions of $\mathrm{H}_{2} \mathrm{O}$ and add thom to tho main sol'n.

(4) Boil the sol'n to 2 low volumo; add $2-5 \mathrm{ml} 30 \% \mathrm{H}_{2} \mathrm{O}$ c.nd boil off cxooss $\mathrm{H}_{2} \mathrm{O}_{2}$. Ppt with $\mathrm{NH}_{4} \mathrm{OH}$, filtor, and disoard tho ppt, if any is prosont.

(5) Wako the flitinte $0.3 \mathrm{~N}$ in $\mathrm{HCl}$, hont to boiling, and pass in $\mathrm{H}_{\mathrm{S}} \mathrm{S}$ to ppt CuS. Filtor and disoard tho ppt. Tost for comploto ppt'n by again passing in $\mathrm{H}_{2} \mathrm{~S}$.

(6) Boil the filtrato to drivo off oxooss H.S. Adjust tho sol in to pH 2-3 with $\mathrm{NH}_{4} \mathrm{OH}$. Pnss in H,S to ppt ZnS. Filtor and wash tho ppt with $\mathrm{H}_{2} \mathrm{O}$. "Dissolve the $\mathrm{ZaS}$ in $\mathrm{I} \mathrm{N} \mathrm{HCl}$ if desirod or use as is.

Romarks:

The $\mathrm{ZnS}$ in stop (6) should be white. If it is not, further purifioations may be nocossary for $C u$ and $F o$ and porhaps for other metal impuritios such as $\mathrm{Ni}$ and $\mathrm{Cr}_{5}$. This prooeduro has been usod for tho proparation of purc compounds of $2 \mathrm{n}^{65}$.

Soo Hillobrand \& Lundoll (Appliod Inorganio Analysis) for furthor information on $\mathrm{Cu}$ doposition. $8 / 19 / 49$ 
Elomont separatod: Zino

Targot matcrial: Thorium motal (.1-1 gm)

Typo of bbdt: $60^{\prime \prime}$ alphas

Y1old: $\sim 50 \%$

Dogroc of purifioation: $>10^{6}$
Procodure by: Newton

Timo for sop'n: . 3 hrs

Equipmont required, Standard

Procodure: The Th motal is dissolvod in oono HCl plus a for drops of $.2 \mathrm{Y}(\mathrm{NH})_{2} \mathrm{SiF}$ to oloar up the blaok rosiduo. Tho $\mathrm{HCl}$ is dilutod to $Z$ I afian aliquot takon.

(1) Idd $10 \mathrm{mg} \mathrm{Zn}^{++}, 1-2 \mathrm{ml} \mathrm{H} \mathrm{C}_{2} \mathrm{O}_{4}$ (sat.) and $\mathrm{HrO}_{3}$ to malko $1 \mathrm{MI}$ (10 to $25 \mathrm{ml}.)^{\circ}$ Centrifuse out $\mathrm{Th}\left(\mathrm{C}_{2} \mathrm{O}_{4}\right)_{2}$. Cool in ioo bath and add $3 \mathrm{ml} \mathrm{BeCl}, \mathrm{KSCH}$ roagont. Stir and soratoh glass to ppt, lot $s$ tand 3-5 min. Contri fugo out $\mathrm{ZnH}_{\mathrm{g}}(\mathrm{SCN})_{\epsilon_{2}} \mathrm{ppt}$.

(2) To ppt, add $1.5 \mathrm{ml} 6 \mathrm{~N}$ HNO $_{3}$ and $5 \mathrm{ml} \mathrm{H} \mathrm{H}_{2}$. Boll until ppt dissolvos and for 1-2 minutos longer to romovo docomposition produc to. Diluto to $10 \mathrm{ml}$ and $000 \mathrm{l}$ in cold wator. Ldd $1 \mathrm{ml}$ sat $\mathrm{H}_{2} \mathrm{C}_{2} \mathrm{O}$, and $3 \mathrm{ml}$ $\mathrm{HgCl}_{2}-\mathrm{BBCN}$ roagant. Stir far 3-5 min to ppt. Contrifugo.

(3) Repoat (2) on ppt.

(4) To tho $\mathrm{ZnFg}$ (CMS) add $15 \mathrm{ml}_{4} \mathrm{~N} \mathrm{HNO}_{3}$ and $3 \mathrm{ml} \mathrm{H} \mathrm{H}_{2}$. Boil to dissolvo and for $12 \mathrm{~min}$. Iongor. Diluto to $10 \mathrm{ml}$ and saturate with $\mathrm{H}_{2} \mathrm{~S}$. Centrifugo. To supernate add $1 \mathrm{ml} 6$ I NaOH, 5 mg Bi carrior and saturato with $\mathrm{H}_{2} \mathrm{~s}$. Contrifugo.

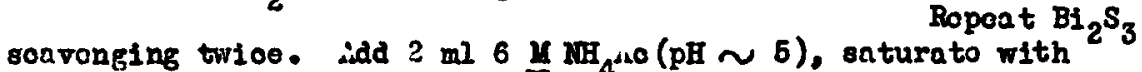
$\mathrm{H}_{2} \mathrm{~s}$, oontrifugo out thi whito 2 nss?

(5) Dissolvo ZnS in $5 \mathrm{ml}$ cono HBr. Evap to drymoss ovcr an opon flamo. Ropoat ovaporation twioo with $5 \mathrm{ml}$ portions of HBr. Take up residuo in $10 \mathrm{ml} 0.5 \mathrm{M} \mathrm{NaOH}$, add $f_{+} \mathrm{ml} 2 \mathrm{II} \mathrm{Ha}_{2} \mathrm{CO}_{3}$ and boll. Krop solution agitatod and add $2 \mathrm{mg} \mathrm{Fo}^{+++}$and $5 \mathrm{mg}^{2} \mathrm{Ba}^{++}$dropmiso. Dirost hot solution 1 min., contrifugo. Ropoat hydroxido soavenging triloo on supornato.

(6) To tho olocr supornato add $4 \mathrm{ml} 6 \mathrm{M} \mathrm{HCl}$ and $1 \mathrm{ml}$ sat $\mathrm{H}_{2} \mathrm{C}_{2} \mathrm{O}_{4} \cdot \operatorname{cool}$ in cold rator and add $5 \mathrm{ml}$ sCl- $\mathrm{FgCl}$, roagent. Stir odoásiomally for 3-5 mi 2. Contrifugo out $2 \mathrm{nHg}(\mathrm{SCF})_{4}$.

(7) Suspond the $\mathrm{ZnHg}(S \mathrm{ON})$, In about $5 \mathrm{ml} \mathrm{H}, \mathrm{O}$ and transfor with aid of vash bottio to a woighod filtor papor in a small Hirsoh funnel. Filtor wilh suotion.

(8) Fash ppt 3 timos with $5 \mathrm{ml} \mathrm{EtOH} \mathrm{(absoluto)} \mathrm{and} \mathrm{throc} \mathrm{times} 5 \mathrm{ml}$

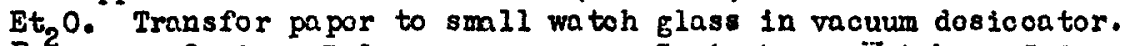
Evapuate 2 min. Roloasc, ovacuate 5 minutos. Toigh as $\mathrm{ZnFg}$ $(\operatorname{SCN})_{4}$ 
Romarks: To mko $\mathrm{HgCl}-\mathrm{KSCN}$ rongont dissolvo 39 gme $\mathrm{KSCN}$ in $200 \mathrm{ml} \mathrm{\textrm {H } _ { 2 } \mathrm { O }}$ Stir in $27 \mathrm{gms}$ HgCI $I_{2}$ whilo diluting to ono litor.

This mothod has bcon described proviously (Fhys. Rov. 7517 (1949)). 


\section{CHIMICAL SEPARATIOHS}

Blowont aeparated: Gallium

Procedure by: H. Hopkins, Jr.

mrget material: $A_{8}$

Time for sep'n: $1 / 2 \mathrm{hr}$.

Type of bbdt: $190 \mathrm{Mor} \mathrm{D}^{+}$

$E_{\text {quipmont roquired: standard }}$

Ylold: $\backsim 80 \%$

Dogreo of purification: radiochomioally pure by faotor of $\backsim 10^{3}$

Prooedure :

(1) Dissolvo As in $10 \mathrm{~N} \mathrm{HWO}_{3}$, add $10 \mathrm{mg}$ Ca oarrior \& $1 \mathrm{mg} \mathrm{Fo}^{+++}$arrier, ovap to noar drymoss

(2) Add $6 \mathrm{~N} \mathrm{HCl}$ and when cool oxtract twioc with oqual volumos of othyl 1 ther.

(3) Wash five times with $1 / 3$ rolumes $6 \mathrm{NHCl}$.

(4) Bxtraot into $5 \mathrm{ml} \mathrm{H}_{2} \mathrm{O}$. Add $\mathrm{KOH}$ to $1 \mathrm{I}$ and oentrifugo.

(5) To supernatant add BCl till just noutral, adjust pH to $\mathrm{n} 5.5$ with treces of $\mathrm{FH}_{4} \mathrm{OH}$ and FAc.

(6) Centrifuge off $\mathrm{Ga}(\mathrm{OH})_{3}$

Remarks: If want to chock ohumical yiold woigh as the 8 hydroxy quinolato proelpitatod from slightly alkaline solution.

$6 / 27 / 49$

P-18m 30 
Elemont separated: Gallium

Prooedure by: Goookermann

Target matorial: 1 \& B1 motal

Time for sepin: 1-2 hrs.

Type of bbdt: 184" all particles

Equipmont roquirede Centriruge, cones, $110^{\circ}$ oven.

rield: in $80 \%$

Degroe of purifioation: Docontamination faotor $M$ 10 from fisaion s sallation produots.

Advantages: Cood yield of pure ca.

Procedure:

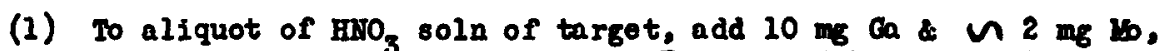
destroy $\mathrm{HNO}_{3}$ \& make $6 \mathrm{~N}$ in $\mathrm{HCl}$. Extract with oqual rol of di-ethyl ether, wash with $1 / 3 \overline{\mathrm{v} l} 6 \mathrm{I} \mathrm{HCl}$. Re-ext Ca into $2 / 3 \mathrm{vol} \mathrm{H}_{2} \mathrm{O}$.

(2) Boil out ether. Nake $0.3 \mathrm{II}$ in FCl add $1 \mathrm{ml}$ aloohol soln of a-benzoin oximo to ppt 15.

(3) Ppt $\mathrm{Bi}_{2} \mathrm{~S}_{3}(6 \mathrm{mg})$ three timas.

(4) Boil out $\mathrm{H}_{2} \mathrm{~S}$. Wake $1 \mathrm{I}$ in $\mathrm{KaOH}, 0.2 \mathrm{H}$ in $\mathrm{Ka}_{2} \mathrm{CO}_{3}$ ppt $\mathrm{Fo}(\mathrm{OH})_{3}$ \& $\mathrm{BaCO}_{3}$ soâvenge three $t$ imes.

(5) Lake soln $6 \mathrm{~N}$ in HCl \& ext with 1 1/2 vol other. Tlash othor with 6 II $\mathrm{BCl} \&$ refextract $\mathrm{Ca}$ into $\mathrm{H}_{2} \mathrm{O}$.

(6) Boil out ethor. Bvap to dryness with $5 \mathrm{ml}$ cono. HDr three timos. Tako up residue in $10 \mathrm{ml} 6 \mathrm{II} \mathrm{HCl} \mathrm{\&} \mathrm{repeat} \mathrm{ether} \mathrm{extrn.}$

(7) Dilute $\mathrm{H}_{2} 0$ layer to $35 \mathrm{ml}$ \& heat to $60^{\circ} \mathrm{C}$. Add $3 \mathrm{ml}$ of 8-hydroxyquinoline soln ( $50 \mathrm{~g} / 1$ in $2 \mathrm{H}$ HAC) $26 \mathrm{H} \mathrm{NH}_{4}$ so droprise until pe runent yellow ppt forms, thon add $1 \mathrm{ml}$ excess." Add aorosol \& filter, wash with $10 \mathrm{ml}$ rarm H, 0 , trico with $5 \mathrm{ml} 001 \mathrm{~d} \mathrm{H} 0$, dry $15 \mathrm{~min}$. at $110^{\circ} \mathrm{C}$. Peigh as $\mathrm{Ca}$ 8-hydroxyquinolate (72 $\mathrm{ig}$ por $10 \mathrm{mg} \mathrm{Ga}$ ).

Remaries: Very bulky heavy ppt per me Ga. Callium ferrooyanide pptno were snoluded in the original procedure but were tosted \& disoarded as unsatisfactory. $\mathrm{HNO}_{3}$ can be destroyed in step (1) by adding hydroxylamino and heating.

$7 / 6 / 49$

P-13-37 
Flement separated: Cormanium

Target matorial: As

Type of bbdt: 190 ller $\mathrm{D}^{+}$
Prooodure by: H. Hopkins

Time for sep'n: $1 \mathrm{hr}$.

Equipment required: oentrifugo, 100 co distillation apparatus

Yleld: Eroater 90\%

Degree of purification: radioohomionlly pure by factor of $\backsim 10^{3}$

Proceduro:

(1) Dissolve As in $10 \mathrm{H}_{\mathrm{H}^{\circ}} \mathrm{HrO}_{3^{\circ}}$ Add $10 \mathrm{mg}$ fe carrier and holdback (Cr through So) carriors.

(2) Distil Ge from $20 \mathrm{ml}$ boiling $6 \mathrm{NI} \mathrm{HCl}$ in slow stroam of $\mathrm{Cl}_{2}$. Catch distillate rapor in dry ice-acetone-cooled oollector.

(3) Thon $1 / 4$ remins in distilling flask add more HCl and repeet.

(4) Add $\mathrm{NH}_{2} \mathrm{OH} \cdot \mathrm{HCl}$ to distillato until no further reaction occurs.

(5) Pass $\mathrm{H}_{2} \mathrm{~S}$ into tho still cold solution.

(6) Centrifugo off $\mathrm{GeS}_{2}$.

Remarke: Whon looking for a omall amount of Ge in predence of a large amount of Se ectivity, a special separation of Se should be performed. (see 34-1).

$6 / 27 / 49$

$P-18-29$ 


\section{CHEMIXAL SEPARATIONS}

Element separated: Germanium

Target material: Thorium metal (.1-1 gm)

Type of bbdt: $60^{\prime \prime} \mathrm{a}^{\prime s}$

Yield: undetermined

Derree of purifioation: $20^{5}$ to $10^{6}$
Prooedure by: Nowton

Time for sep'n: $\sim^{2-3}$ hrs.

Equipment roquirod: still

Procedure: The Th motel is dissolved in oono $\mathrm{HCl}+$ a fow drops 2 4 solutions $\left(\mathrm{MP}_{4}\right)_{2} \mathrm{SIF}$ to olear up bleok residue. The HCl is diluted to $2 \mathrm{I}$ and an siliquot taken.

(1) Add $10 \mathrm{mg}$ Ge + As. Wake to $15 \mathrm{ml}, 6 \mathrm{~N}$ in Ecl. Add orystal of IIf $I$ and treat with $\mathrm{H}_{2} \mathrm{~S}$ at 100 tomp. Tiash with $6 \mathrm{I}_{2} \mathrm{SO}_{4}$ saturated with $B_{2} S$.

(2) Dissolvo ppt in $1 \mathrm{ml}$ cono. $\mathrm{HH}_{4} \mathrm{OH}$. Dilute to $20 \mathrm{ml}$. Discard any residue. Transfer to glass still and add $10 \mathrm{mg}$ each of $\mathrm{To}, \mathrm{Sb}$ and $\mathrm{Sn}$ carriers. Add $10 \mathrm{ml}$ cono $\mathrm{HCl}$ and a orystal of

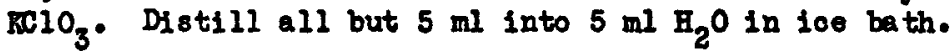

(3) Pass $\mathrm{H}_{\mathrm{S}} \mathrm{S}$ into GeCl $\mathrm{Golution}_{4}$ and centrifuge. Add $10 \mathrm{mg} \mathrm{As}_{8}$ to ppt of $\mathrm{GeS}_{2}$ and ropeat GeCl 4 distillation (step 2 ).

(4) Repreoipitate GeS ${ }^{\circ}$ wash with $\mathrm{H}_{2} \mathrm{O}$, alcohol, and ether. Dry at $110^{\circ}$ C. WeIgh $a^{2} \mathrm{CoS}_{2}$.

Romarks: $10 \mathrm{mg} \mathrm{Go}_{0}=18.79 \mathrm{mg} \mathrm{GeS}{ }^{\circ}$

This method has been described previsusly (Fhys. Rev. 7517 (1949)).

$8 / 23 / 49$

P-18-291 


\section{CHTMCAL SRPARATIOAS}

Eloment soparated: Arsenio

Target material: As

Type of bbdt: 190 Ifor $\mathrm{D}^{+}$
Prooodure by: H. Hopkins, Jr.

Time for sep'n: $1 \mathrm{hr}$.

Equipmont required: atandard distillation apparatus 100 00

Y101d: greator $80 \%$

Degroe of purification: radioohemically pure by factor of $\sim 100$

Prooodure:

(1) Dissolve As in conc. $\mathrm{HHO}_{3}+\mathrm{HCl}$. Add carriors of Se and elements below, (2 mg).

(2) Separato So by prooedure given undor So (34-1)

(3) To supernatant add $\mathrm{BCl}$ to make a $3 \mathrm{II}$ solution containing 10 ms As/ml.

(4) Pass $\mathrm{H}_{2} \mathrm{~s}$ into hot solution and stir vigorously. Repeat.

(5) Centrifuge off procipitate and wash with B

(6) Dissolvo As and Ge salts with dilute KOH, loaving CuS behind.

(7) Separato Ge by distilling from $20 \mathrm{ml}$ of boiling $6 \mathrm{~N} \mathrm{HCl}$ in a slov stroam of ohlorine. ithen $1 / 4$ volume romains, add $6 \mathrm{~N} \mathrm{HCl}$ and repeat.

(8) Procipitate $\mathrm{As}_{2} \mathrm{~S}_{5}$ from 3 II HCl.

Remarke: So and As may first be removed together by volatilizing the elomonts along a quartz or pyrex tube. 


\section{CHELICAL SEPARATIONS}

Elemont soparated: Arsonio

Prooodure by: Cockkormam

Target matorial: $N 1$ B Bi motal

Timo for sep'n: Fow hrs.

Type of bbdt: 184" all partiolos

Equipmont roquirod: Contrifuge, tubes, all glass distillation flask, tank $\mathrm{Cl}_{2} \& \mathrm{HCl}$, $100,110^{\circ}$ ovon.

Dogroo of purification: Deoontamination faotor $v \cdot 10^{4}$ from fission \& spallation products.

Advantages: Frojoot fission product procodure.

Procoduro:

(1) To aliquot of $\mathrm{HNO}_{3}$ soln of target, add $10 \mathrm{mg} \mathrm{As}$ as $\sim 10 \mathrm{mg} \mathrm{Gc}$, boil noarly to drymoss, take up in $15 \mathrm{ml} 6 \mathrm{~N} \mathrm{HCl,} \mathrm{add} \mathrm{orystal} \mathrm{of}$ $\mathrm{NH}_{4} \mathrm{I}$, sat with $\mathrm{H}_{2} \mathrm{~S}$ at 100 temp. Fash with $\mathrm{H}_{2} \mathrm{~S}-\mathrm{sat} 6 \mathrm{II}_{2} \mathrm{SO}_{4}$.

(2) Dis solvo ppt in $1 \mathrm{ml}$ oonc $\mathrm{MH}_{4}$ OH \& dilute to $10 \mathrm{ml}$ (discard any rosidue). Transfer to a glass still \& adi v10 mg oaoh To, Sb, \& Sn. Add $10 \mathrm{ml}$ cone $\mathrm{HCl}$ \& distill all bui $5 \mathrm{ml}$ in a $\mathrm{Cl}_{2}$ stroam into $5 \mathrm{ml} \mathrm{H}_{\mathrm{O}} \mathrm{O}$ in an ioe bath. Add $5 \mathrm{ml}$ oono HCl $10^{2} \mathrm{mg}$ Go to residue in flask \& ropeat distillation.

(3) To rosiduc from $\mathrm{GCCl}_{4}$ distillation, pass in $\mathrm{HCl}$ gas to romovo $\mathrm{Cl}_{2}$, add 1 ml sat CuCl in oono $\mathrm{HCl}$, and distill over $5 \mathrm{ml}$ in an BCl stream into $10 \mathrm{ml}$ cono BCl in an 100 bath. Add CuCl-HCi to residuo d distill furthor.

(4) Pass $H_{2} S$ into distilla te e oentrifugo out $\mathrm{As}_{2} \mathrm{~S}_{3}$. Dissolvo in $1 \mathrm{ml}$ cono if ${ }_{4} \mathrm{OH}$, add $n 10 \mathrm{mg} \mathrm{Te}, \mathrm{Sb}$, \& Sn \& ropoat $\mathrm{AcCl}_{3}$ distillation.

(5) Ppt As $\mathrm{S}_{3}$ again, dissolve in $1 \mathrm{ml}$ oono. $\mathrm{NH}_{4} \mathrm{OH}$, add $10 \mathrm{ml}$ conc. $\mathrm{HCl}$, sat with $\mathrm{H}_{2} \mathrm{~S}$, filter, wnsh with $\mathrm{H}_{2} \mathrm{O}, \mathrm{EtOH}$, \& ethor, dry 10 min. at $110^{\circ} \mathrm{C}$. TJoigh as ${ }^{18} \mathrm{~s}_{3}(16.4 \mathrm{mg}$ per $10 \mathrm{mg} \mathrm{As})$.

Romarks: Tank HCl \& $\mathrm{Jl}_{2}$ aro rather unploasant \& corrosivo to work with. Proceduro is fairly slow. Ge oan bo soparated along with the As as indicatod. 
Element separated: Arsento

Target materiel: Thorium motal $(.1-1 \mathrm{gm})$

Iype of bbdt: $6 C^{\prime \prime} a^{\prime} 8$

Yield: undetermined

Degree of purification: $10^{5}$ to $10^{6}$

Procedure: The Th motal is dissolved in cono $\mathrm{HCl}+$ a few drops 24 solution $\left(\mathrm{NH}_{4}\right)_{2} \mathrm{SIF}_{6}$ to olear up black residue. The HCl is diluted to $2 \mathrm{II}$ and an Siliquot takon.

(1) Add $10 \mathrm{mg} \mathrm{Go}+\mathrm{As}$. Hke to $15 \mathrm{ml}, 6 \mathrm{~N}$ in HCl, Add orystal of Wh I and treat with $\mathrm{H}_{2} \mathrm{~S}$ at 100 tomp. Fash with $6 \mathrm{~N} \mathrm{H}_{2} \mathrm{SO}_{4}$ saturated with $\mathbf{B}_{2} \mathrm{~S}$.

(2) Dissolvo ppt in $1 \mathrm{ml}$ cono. $1 \mathrm{H}_{4} \mathrm{OH}$. Dilute to $10 \mathrm{ml}$. Discard any residue. Transfor to glass still and add $10 \mathrm{mg}$ each of To, $\mathrm{Sb}$ and $\mathrm{Sn}$ carriers. Add $10 \mathrm{ml}$ cono $\mathrm{HCl}$ and a orystal of $\mathrm{KClO}_{3}$.

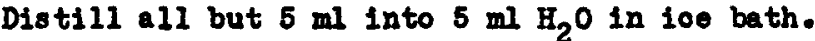

(3) Add $5 \mathrm{ml}$ conc. HCl, $10 \mathrm{ml} \mathrm{Ge}$ and $\mathrm{KClO}$, to remaining solution in still and repest. (Disoard).

(4) To residue from $\mathrm{CoCl}_{4}$ distillation, pass in $\mathrm{HCl}$ gas to remove $\mathrm{Cl}_{2}$.

(5) Add $1 \mathrm{ml}$ sat. CuCl soln in oono. HCl and distill over $5 \mathrm{ml}$ in HCI tream into $10 \mathrm{ml}$ cono $\mathrm{HCl}$ in 100 bath.

(6) Add CuCl - HCl and distill again. Pass $\mathrm{H}_{2} \mathrm{~S}$ into distillate and ppt $\mathrm{As}_{2} \mathrm{~S}_{3} \cdot$

(7) Dissolve in $1 \mathrm{ml}$ cono $\mathrm{MH}_{4} \mathrm{OH}$, add $10 \mathrm{me} \mathrm{Te}, \mathrm{Sb}$ and $\mathrm{Sn}$ and ropost distillation. Ppt $A s_{2} \mathrm{~S}_{3}$ again, dissolve in $1 \mathrm{ml}$ cone. $\mathrm{NH}_{\mathrm{H}} \mathrm{OH}$. Add $10 \mathrm{ml}$ gono $\mathrm{HCl}$, sât $\mathrm{H}_{2} \mathrm{~S}$. Flter, wash with $\mathrm{H}_{2} \mathrm{O}, \mathrm{EtOH}$, ether. Dxy at $110^{\circ}$. Tolgh as $\mathrm{As}_{2} \mathrm{~S}_{3}$.

Rewarks: Inis mothod has been described previous ly (Phys. Rev. 7517 (1949)).
$8 / 23 / 49$

$P=18-290$ 
CHSIICAL SEPARATIONS

Bilenort separated: Selenium

Ti' - jot material: As

Type of bbdt: 190 Mer $\mathrm{D}^{+}$
Prooedure by: H. Eopleins, Jr.

Tino for sep'n: $3 / 4 \mathrm{hr}$.

Equipmont requirod: contr. tubes, eto.

leld: $>90 \%$

beree I purification: radiochemically pure by faotor of un 100

Procedure:

(1) Dissolve As motal in minimum $10 \mathrm{~N} \mathrm{MNO}_{3}$.

(2) Idd $5 \mathrm{mg}$ Se carrior, evap. to near drynoss to remove $x \mathrm{HNO}_{3}$

(3) Nale up to $3 \mathrm{ml}$ with $1 \mathrm{~N} \mathrm{HCl}$, add $\mathrm{NH}_{2} \mathrm{OH} \cdot \mathrm{HCl}$ until So starts to ppt from hot soln.

(4) Add $1 \mathrm{ml} 1 \mathrm{~N} \mathrm{KI}$, heat $5 \mathrm{~min}$, centrifuge off mixturo of so and $\mathrm{I}_{2}$.

(5) Dissolvo with minimum fumine [NO $_{3}$, repoat precipitation.

Remarks: In prosenos of carriers separates from all elements bolow So.

If want to woigh to check chemical yield do not add KI in step 4. This slows down the precipitation considerably, so much more tims must bo allowed for complete pptn of tho Se.

$6 / 27 / 49$

P-18-20 


\section{CHEHIICAL SEPARATIORS}

Elemont soparatod: Sclonium

Targit matorial: on 1 E Bi motal

Typo of bbdt: 184 " all pnrticles
Procodure by: Goockar mann

Timo for sep'n: $<1 \mathrm{hr}$.

Equipmont roquired: Contrifuge, and glass distillation Plagks, conos, tank $\mathrm{SO}_{2}$. $110^{\circ}$ ovon, 100.

Yield: $\backsim 90 \%$

Dogroo of purifioation: Dcoontamination factor u $10^{4}$ from fission is spallation products.

Advantages: Cood yiold of pure So in rolatively short tino.

Procodure:

(1) To aliquot of Hro $_{3} 801 \mathrm{n}$ of targot, add $10 \mathrm{mg}$ So \& To, $10 \mathrm{ml}$ cono. $\mathrm{HBr}$, \& $0.5 \mathrm{ml} \mathrm{Iiq}^{3} \mathrm{Br}_{2}$ in a glass still. Distill in air stroam to $3 \mathrm{ml}$ rosiduo, into $5 \mathrm{ml}$ sat $\mathrm{Br}_{2}$ wator in 100 bath.

(2) Hoop at loc tomp \& reduco to So (rod) with $\mathrm{SO}_{2}$ or $\mathrm{NH}_{2} \mathrm{OH} \cdot \mathrm{HCl}$. Add aorosol \& contrifugo.

(3) Dissolve So in for drops cono $\mathrm{BNO}_{3}$, add $10 \mathrm{ml}$ oono. $\mathrm{HCl}$ \& reduce with $\mathrm{SO}_{2}$ in an 100 bath. Contrifugo with acrosol.

(4) Ropoat SeBr distillation is So pptns as ofton as neoossary for dosirod purity.

(5) Ppt So, filtcr, wash throe times with 5 ml $\mathrm{H}_{2} \mathrm{O}$, throo times with $5 \mathrm{ml}$ BtoH, throo times with $5 \mathrm{ml}$ ethor, dry $10 \mathrm{~min}$. at $110^{\circ} \mathrm{C}$. Troigh as Se.

Romarks: Procedure can bo mado short cnough to catch half-lives ( I hr.

$7 / 6 / 49$

P-18-42 


\section{CHEOICAL SEPARATIONS}

Elcmont soparated: Bromino

Procodure by: Gocokormann

Targot material: $\cap l$ g Bi motal

Timo for sop'n: 1-2 hrs.

Typo of bbdt: 184" all partioles

Equipment required: Contrifugc, tubes, $110^{\circ}$ oven

Yiold: in 60\%

Dogreo of purification: Docontamination factor $\sim 10^{4}$ from fission \& spallation products.

Advantagos: Good yicld of puro Br.

Procodure:

(1) To aliquot of $\mathrm{HHO}_{3}$ soln of target, add $10 \mathrm{mg} \mathrm{Br} \mathrm{Br}^{-} \mathrm{I}^{-}$, make $1 \mathrm{I}$ in $\mathrm{HNO}_{3}$, add a fow drops of $0.1 \underline{M} \mathrm{NaNO}_{2}$, extract $\mathrm{I}_{2}$ into oqual $\mathrm{Fol}$ $\mathrm{CCl}_{4}$.

(2) Add equal vol $\mathrm{CCl}_{4}$ to aquoous phaso add 1.1 L $\mathrm{KunO}_{4}$ dropwisc until color porsists. 通ko fivo extractions of $\mathrm{Br}_{2}{ }^{\circ}$

(3) Combino $\mathrm{CCl}_{4}$ layors 4 wash with $1 \mathrm{~N} \mathrm{HrO}_{3}$ containing $\mathrm{KMnO}_{4}$. Add 10 $\mathrm{ml} \mathrm{H}_{2} \mathrm{O} \& 0.1 \mathrm{II} \mathrm{NaHSO}_{3}$ dropwise until both layore are colorless. Wash aq layor with $\mathrm{OCI}_{4}$.

(4) Mako $1 \mathrm{I}$ in HiNO 3 , add $\backsim 10 \mathrm{mg} \mathrm{I}^{-}$, warm a fow min. to oxidizo $\mathrm{SO}_{3}{ }^{=}$, add few drops 0.1 II $\mathrm{NaNO}_{2}$ \& oxtract $\mathrm{I}_{2}$ fivo timos with $10 \mathrm{ml} \mathrm{Ccl}_{4}$.

(5) Ropoat $\mathrm{nhO}_{4}$ oxidation \& $\mathrm{Br}_{2}$ cxtrn \& reduction.

(6) Repeat $\mathrm{I}_{2} \& \mathrm{Br}_{2}$ oxtrn cyclos as noodod for purity.

(7) lake last aq soln of $\mathrm{Br}^{-} 1 \mathrm{~N}$ in $\mathrm{HNO}_{3}$, hoat, add $2 \mathrm{ml} 0.1 \mathrm{~N} \mathrm{AgNO}_{3}$, stir, digost fow min., filtēr, wash throo timos with $5 \mathrm{ml} \mathrm{H}_{2} \mathrm{O}$, ItOH, othor, dry $10 \mathrm{~min}$. at $110^{\circ} \mathrm{C}$. Cis as AfBr $(23.5 \mathrm{mg}$ per 10 mg $\mathrm{Br}$ ).

Romarks: The bismuth fission work only required three $I_{2}-B r_{2}$ oxtrn oyoles. To prevunt possiblo lossos of traco Br during dissolving of tho bismuth, ono might dissolvo the targot in $6 \mathrm{~N}$ HirO ${ }_{3}$ with tho carric $\mathrm{Br}^{-}$prosent in a Glase still, and distill $\mathrm{Br}_{2}$ or $\mathrm{HBr}$ dirootly from this soln into $\mathrm{H}_{2} \mathrm{O}$

in an ico bath. 
Elomont soparated: Bromine

Targot material: Tantalum

Typo of bbdt: Ta +350 Uor protons

\author{
Proceduro by: Lindnor \\ Ioclified by: Iraurann \\ Timo for sop'n: 2 hours
}

Equipment requirod: Sop. funncl

\section{Yiold: in $40 \%$}

Dogroo of purification: oxccllent - factor of $\sim 10^{4}$ from fission and spallation products.

Advantages: Protides for the scparation of $\mathrm{Br}_{2}$ from targets requiring HF$\mathrm{HWO}_{3}$ mixturos for solution of tho targot. ${ }^{2}$ In theso cascs glass oquipmont is impossible and tho method of distillation of tho halogens is impractioal.

Prooodurc,

(1) Proshly prooipitatod AgBr (woll washed to remove $x s \mathrm{Ag}^{+}$) contalning $10 \mathrm{mgs}$ of bromino as silvor bromido is addod to $15 \mathrm{mls}$ of $48 \% \mathrm{HF}$ solution contained in a lustoroid test tubo. The target foil is placod in solution and conc. $\mathrm{HNO}_{3}$ is addod as required for solution of tho foll. (SOO. (a) und or romarks.)

(2) After the target has dissolved the solution is allowed to stand for 15 minutes, (Soo (b) under romarks.) tho supornatant targot solution is removed, tho $1 \mathrm{gBr}$ washod twico with $10 \mathrm{mls}$ hot wator. $10 \mathrm{mls}$ of water is addod and the slurry is saturatod with $\mathrm{H}_{2} \mathrm{~S}$, then contrifuged.

(3) Tho supornatant solution is boiled to romovo $\mathrm{H}, \mathrm{S}, 10 \mathrm{mgs} \mathrm{I}^{-}$is addod, tho solution is mado $1 \mathrm{~N}$ in $\mathrm{HNO}_{3}$ a for arops of $\mathrm{NaNO}_{2}$ is addod and the lodinc oxtracted into $10^{3} \mathrm{mls}^{-}$of $\mathrm{CCl}_{4}$. (oxtract a total of 5 tinos).

(4) $10 \mathrm{mls}$ of $\mathrm{CCl}_{4} 18$ addod to tho aquoous phaso and $0.1 \mathrm{M} \mathrm{Kmo}$ solution is addod until tho Bromino color persists. Extract $\mathrm{Br}_{2} 5$ timos (total) (5) Combino the $\mathrm{Br}_{2}-\mathrm{CCl}$ cxtract, wash vith $1 \mathrm{~N} \mathrm{HNO}_{3}$ containing $\mathrm{KMnO}_{4}$,
add $10 \mathrm{mls} \mathrm{B}^{2}$ and $\mathrm{O}_{.1} \mathrm{~N} \mathrm{NaESO}_{3}$ dropwiso until both laycrs aro 0010 rloss. (Soo (o) undor romarkes) Tash aqueous layor with $\mathrm{CCI}_{4}$.

(6) Wakc $1 \mathrm{~N}$ in $\mathrm{HNO}_{3}$ add $10 \mathrm{mgs} \mathrm{I}^{-}$, warm for a fov minutos to oxidizo tho $\mathrm{SO}_{3}{ }^{5}$, add $a^{3} \mathrm{fow}$ dross of $0.1 \mathrm{M} \mathrm{NaNO}$ and oxtract the $\mathrm{I}_{2} 5$ times with $\mathrm{CCl}_{4}$.

(7) Ropoat (4) and (5) as nouded (A total of 3 times was usod for purification abovo.)

(8) Lake last aqueous solution of $\mathrm{Br}^{-} 1 \mathrm{~N}$ in $\mathrm{HNO}_{3}$, hoat, add $2 \mathrm{mls}$ $0.1 \mathrm{~N} \mathrm{AFNO}_{3}$. Stir, digost a fow minutos, wash throc timos with $5 \mathrm{mls} \mathrm{H}_{2} \mathrm{O}, 5 \mathrm{mls} \mathrm{C}_{2} \mathrm{H}_{5} \mathrm{OH}, 5 \mathrm{mls}$ cthor. Dry for $10 \mathrm{mins}$. at $110^{\circ} \mathrm{C}$. 
Romarks:

(a) This roaction procoods rapidly and at no time should thero bo an $x s$ of $\mathrm{HHO}_{3}$. Hoating is not roquirod and lustoroid tube may bo 100 coolod if nocossary.

(b) Procoduro doponds upon an oquilibration botwoon AgBr and tracer bromide ion in tho targot solution. If tho traoor bromino woro In a higher oxidation stato this oquilibration walld bo impossiblo. Howover, since the Th is boing dissolvod it may bo assumed roduotivo conditions oxist and a.ll tho tracor is in the form of bromino or bromidc.

(0) Unloss the solution is kopt aoid $\mathrm{MnO}_{2}$ will procipitato. Tho $\mathrm{WhO}_{2}$ prooipitation may also bo avoidod $1 f^{2}$ tho solution is warmod boforo pormanganato aduition.

(d) Stupe (3) to (9) are R.H.Goockermann proooduro for bromino. (35-1)

(o) $I_{2}$ might also bo soparatod by this proooduro. 
Element separateds Bromine

Target material: Thorium motal $(.1-1 \mathrm{gm})$

Typo of bbdt: 60" metal
Procedure by: Newton

Time for sep'n: $\sim 1 \mathrm{hr}$.

Equipment requirod: Standard

Yleld: $\sim 50 \%$

Degree of purification: $\sim 10^{6}$ except from $I^{-}\left(\sim 10^{4}\right.$ from $\left.I^{-}\right)$

Procedure: The Th metal is dissolved in cone. HCl + a few drops .2 M solution $\left(\mathrm{NH}_{4}\right)_{2} \mathrm{SiF}_{6}$ to cloar up blaok residue. The $\mathrm{HCl}$ is diluted to $2 \mathrm{~N}$ and an aliquot taken. Sample added to $15 \mathrm{ml} \mathrm{I} \mathrm{N} \mathrm{HNO}_{3}$ in $50 \mathrm{ml}$ separatory funnel. Add $10 \mathrm{mg} \mathrm{Br}$ carrier and $10 \mathrm{mg} \mathrm{I}$ carrior.

(1) Add $\mathrm{KMnO}_{4}(0.1 \mathrm{~N})$ dropwise until oolor persists (15 drops). Make 5 successivo extraotions with $\propto \mathrm{l}_{1}$. Discard aqueous. To $\mathrm{CCl}_{4}$ layer add $10 \mathrm{ml}$ water and $0.1 \mathrm{NaHSO}_{3}$ until $\mathrm{CCl}_{4}$ layer colorless on shakinc. Disoard the $\mathrm{CCl}_{4}$. $^{-}$

(2) To aqueous add $2 \mathrm{mI} \mathrm{HNO}$ and $10 \mathrm{mg} \mathrm{I}$, add 4 drops of $0.1 \mathrm{M} \mathrm{NaNO}_{2}$. Extract five times with $\mathrm{CCl}_{4}$. Add more $I^{-}$and repeat extraction with four more portions of $\mathrm{CCl}_{4}$.

(3) Add $\mathrm{BmO}_{4}$ to oxidize $\mathrm{Br}^{-}$. Bxtraot 5 timos with $\mathrm{CCl}_{4}$.

(4) Bxtract $\mathrm{CCl}_{4}$ with $\mathrm{NaHSO}_{3}$. Add $\mathrm{Ag}^{+}$to ppt $\mathrm{AgBr}$. Fil ter wash three times with $5 \mathrm{ml} \mathrm{H} O$ and three times with $5 \mathrm{ml}$ EtoH. Dry at $110^{8}, 10$ min and weigh. $10 \mathrm{mg} \mathrm{Br}=23.5 \mathrm{mg} \mathrm{AgBr}$.

Remarks: This mothod has been described previously (Phys. Rev. 7517 (1949)). 


\section{CEE:IICAL SEFARATIONS}

Element seperated: Rubidium

Target material: n 1 \& Bi metal

Typo of bbdt: 134 " all nartioles
Procedure by: Goookermann

Timo for sep'n: Severnl hrs.

Equipment required: Centrifuge, tubes, small Pt dish, 100. $110^{\circ}$ oven

Yiold: Fo $\cap 30 \%$

Degreo of purifioation: Rb looked very olean by a factor of at least $10^{3}$.

Advantages: Supposed to givo Fo puro of all elemento and separate it from Cs.

Prooedure:

(1) To aliquot of Frro soln of target, add $20 \mathrm{mg} \mathrm{Rb} C \mathrm{Cs}$ \& ml oono. $\mathrm{HClO}_{4}$. Evap to fuming. cool, transfor to cont tube. wi th $15 \mathrm{ml}$ absolute EtOH. Cool in 100 bath 10 min. with stirring. Fash ppt twice with $10 \mathrm{ml}$ absolute EtOH.

(2) Dissolve in dilute HCl \& scav with $\mathrm{Te}, \mathrm{Ru}, \mathrm{Sn}, \mathrm{Sb}$, \& $\mathrm{Ag}$ sulfides (2 me each) by adding $\mathrm{H}_{2} \mathrm{~s}$.

(3) Soav with $\mathrm{NH}_{3}$ pptn of Ia, Co, Y, Zr, \& Cb (2 mg each).

(4) Scav with Sr \& Ba carbomates (1 mg)

(5) Acidify with $\mathrm{BCl}$, repeat (2).

(6) Repeat (3).

(7) Scar with $\mathrm{La}(\mathrm{OH})_{3}$.

(8) Scav with Sr \& Ba carbonates \& Y, Zr, \& Cb hydroxides.

(9) Aoidify with $\mathrm{HCl}$, evap to dryness in a Pt dish, destroy $\mathrm{HE}$ Cl by adding a fow drops $\mathrm{BNO}_{3}$ and baking carofully (do not overheat or Cs may be $108 t$ ).

(10) Dissolve in a minimum of $\mathrm{H}_{2} \mathrm{O}$, transfer to a cons \& oent out any residue, evap to dryness in the cone. Add $6 \mathrm{ml} \mathrm{H}_{2} \mathrm{PtCl}_{6} \& 6 \mathrm{ml} \mathrm{EtCH}$, wash Rb \& Cs chloroplatinates with BtOH.

(11) Dissolve in HCl \& repeat Te sulflde soavenging.

(12) Bepeat $\mathrm{NH}_{3}$ pptn of La \& $\mathrm{Fe}$ hydroxides.

(13) Repeat $\mathrm{Sr}$ \& Ba carbonate soav (14) Aoidify with $\mathrm{HNO}_{3}$, ad.d $\mathrm{HCl}$, evap to drymess, bake off ammonium salts
oarefully again. 
(15) Cs - Talee up residue in $20 \mathrm{ml} 6 \mathrm{~N} \mathrm{HCl,} \mathrm{add} 1 \mathrm{ml}$ siliootungstio acid soln \& digost. (Save this supn. for Rb fraction).

(16) Ib - Ppt a Cs siliootungstate soar from the supn saved. Erap until orystallization begins, add $\mathrm{H}_{2} \mathrm{PtCl}_{6}$ \& EtOH, rilter, wash with $\mathrm{EtoH}, \mathrm{dry} 10 \mathrm{~min}$. at $110^{\circ} \mathrm{C}$. Weigh as $\mathrm{Bb}_{2} \mathrm{FtCl}_{6}(33.9 \mathrm{mg}$ por 10 ms $\mathrm{Eb}$ ).

Remarks: Hoyes \& Bray rooomend ppting the $R b$ away from the $C_{s}$ with sodium 6-chloro-5-nitrotoluenemotasulfonate, which we now have on hand, \& then ppting the $\mathrm{Cs}$ silicotungstate. This may give better Cs-Rb separation. It may be better to weigh the Cs as Cs, PtCl after purification. It has been alleged that $2 \mathrm{BiI}_{3} \cdot 3 \mathrm{CsI} \mathrm{pptn}$ is spooifio for Cs. I tried the pptn of Rb away from Cs with cold sat sodium titartrate but tho results wore very psor. Hore Cs siliootungstate pptns with Rb holdback present would probably give clean Cs.

The fuming of $\mathrm{BClO}_{4}$ oante done easily in $40 \mathrm{ml}$ pointed centrifuge cones.

For Cs sep'n from same target soo (55-1). 


\section{CHELICAL SEPARATIORS}

Element scparated: Rubidium

Target material: $\quad \mathrm{NH}_{4} \mathrm{Br}_{\mathbf{r}}$

Typo of bbdt: $40-140 \mathrm{Kov} a$
Prooedure by: Harraker

Time for sep'n: $n 30$ min.

Equipment required: No speoial equipment

Y1eld: $\sim 40 \%$

Degree of purification: Good, at best a factor of 100 except from other alkali metals.

Advantages: Fast, easy, and gives almost oarrier-free aotivity.

Prooedure:

(1) $\mathrm{NH}_{\mathrm{A}} \mathrm{Br}$ in poroolain orucible, add a fow drops of dil. $\mathrm{KCl}$, then heat strongly in hood, usinf hurner, $\mathrm{WH}, \mathrm{Br}$ sublimes off, $\mathrm{Kr}$ activities evaporate. Continue heating till no more solid is visible. Tash orucible with a small amount of dilute mio,. (For mass speotrographio purposes, this is suffioiontly puro).

(2) Add about $1 \mathrm{mg} \mathrm{Rb}$ carrier, and scavonge the solution with few $\mathrm{mg}$ of $\mathrm{Te}(\mathrm{OH})_{3}, \mathrm{MrCO}_{3}, \mathrm{ArCl}$, and any sulfido. This, practioally s peaking remores all impurities exoept alkalis.

Remarks: It should bo noted that no separation is obtained from other alkalis.

If $\mathrm{Rb}$ is not to be used in mass spootrograph, carrier may bo addod initially.

$7 / 14 / 49$

P-18-73 


\section{CEELITCAL SBPA RAT IONS}

Elemont separatod: Rubidium

Parent material: SrClo (traoer or with 50 y gr ourrier) in $10{\mathrm{H}-\mathrm{HClO}_{4}}$

Type of bbdt: lifikine experiment
Procodure by: S. Castner

Time for sep'n: $20 \mathrm{kng}$.

Equipinont required: std, cones, eto.

Y10ld: $\backsim 50 \%$

Degreo of purification: Loss than $2 \% \mathrm{Sr}$ carried along.

Procedure:

(1) Sol'n is heated in boiling $\mathrm{H}_{2} \mathrm{O} . \quad$ (Sol'n. volume $=1 \mathrm{ml}$ ). $50 \mu \mathrm{gms}$ RbNO $_{3}$ are added. Stir.

(2) Cool in toe bath and let stand for 5 minutes. Centrifuge and remove supernatant for later milking. (The $\mathrm{RbClO}_{4}$ may be dissolved in any sol'n if heated).

(3) Add $250 \lambda_{\text {eat. }} \mathrm{Sa}_{2} \mathrm{C}_{2} \mathrm{O}_{4} \mathrm{sol}$ 'n and heat until just dissolved.

(4) Add $50 \mu$ gms Sr${ }^{++}$sol'n and oentrifuge the ppt while the sol'n is still hot.

(6) The supernatant containine the $\mathrm{Rb}$ is then removed.

Romarke: The majority of the $\mathrm{Rb}$ loss is carried away in the $\mathrm{Sr}$ scarenge as the sol'n cools rapidly. The Sr parent sol'n oontains only approx. $1 \%$ of the IB after the milking. 
Element separated: Strontium

Target material: $\sim 1 \mathrm{~g}$ Bi metal

Typo of bbdt: 184" all particles
Procedure by: Goeckermann

Time for sep'n: 1-2 hrs.

Equipment required: Centrifuge, tubes, ice, vacuum dessicator

Yield: $\sim 80 \%$

Degree of purification: Deoontamination factor $\backsim 10^{4}$ from fission \& spallation products. SY docontaminated $>100$ from $\mathrm{Ba}$.

Advantages: Good yield of Ba \& Sr, separation from all other elements except Ra, very good separation of $\mathrm{Sr}$ \& from eaoh other.

Procedure:

(1) To aliquot of $\mathrm{HNO}_{3}$ sol'n of target, add $10 \mathrm{mg}$. Sr \& $\mathrm{Ba}, 30 \mathrm{ml}$ fuming HNO $_{3}$, digest cold $1-2 \mathrm{~min}$.

(2) Dissolve ppt in 2 ml $\mathrm{H}_{2} \mathrm{O}$ \& reppt with $15 \mathrm{ml}$ fuming $\mathrm{HNO}_{3}$.

(3) Dissolve ppt in $5-10 \mathrm{ml} \mathrm{H}_{2} \mathrm{O}$, add $5 \mathrm{mgFe}^{+3}, 2 \mathrm{ppt} \mathrm{Fe}(\mathrm{OH})_{3}$ with tank $\mathrm{NH}_{3}\left(\mathrm{CO}_{3}=\right.$ freol) Reveat $\mathrm{Fo}(\mathrm{OH})_{3}$ soav.

(4) Noutralize supn with $6 \mathrm{~N}$ BrO 3 , add $1 \mathrm{ml} 6$ II HAO \& $2 \mathrm{ml} 6 \mathrm{MHH}_{4} \mathrm{Ac}$. Heat to boling \& add $2 \mathrm{mI} 1.5 \mathrm{M} \mathrm{Na}_{2} \mathrm{CrO}_{4}$ droptriso with stirring. Digest one min. (Save the supn for ${ }^{2} r$ fraction).

(5) Sr - Ppt 5 mg BaCrO soar from supn saved from Ba sepn. Add 2 ml cono. $\mathrm{KH}_{4} \mathrm{OH}$, hoat, add $5 \mathrm{ml}$ sat $\left(\mathrm{NH}_{4}\right)_{2} \mathrm{Ox}$ slowly. Stír 2 min, filter, wash thrê times with $5 \mathrm{ml} \mathrm{H}, 0$, three times with $5 \mathrm{ml}$ EtoH, three times with $5 \mathrm{ml}$ ether, dry like $\mathrm{BaCl}_{2}$. Tieigh as $\mathrm{SrC}_{2} \mathrm{O}_{4} \cdot \mathrm{H}_{2} \mathrm{O}(22.1$ mg per $10 \mathrm{mg} \mathrm{Sr}$ ).

Remarks: Procedure adapted for use when Sr aotivity much greater then Ba. $\mathrm{Ra}$ follows the $\mathrm{Ba}$ well, oan be separated from it by use of a resin column.

For Ba sop'n from same target soo 56-2.

$7 / 12 / 49$ 


\section{CHEHSICAL SBPARATIONS}

Elemont soparatod: Strontium

Target waterial: RbCl ( $30 \mathrm{mg}$ ) finely divided

Type of bbdt: 184" deuterons and protons
Prooodurs by: S. Castner

Time for sep'n: $35 \mathrm{~min}$ without column; $11 / 2 \mathrm{hr}$. with column

Equipment required: $1 \mathrm{ml}$ oones, pipettes, etc.

\section{Yield: in $90 \%$}

Degree of purification: Bxcellent - ज $5 \%$ Rb contemination without column.

.2\% or $1088 \mathrm{Rb}$ oontamination with column.

Advantages: Quick, may be modified to gite carrier free Sr.

Procedure: (1) Dissolve target in $500 \lambda$ of $\mathrm{Na}_{2} \mathrm{C}_{2} \mathrm{O}_{4}(3 \mathrm{gms} / 100 \mathrm{ml})$. Hea: in
boiling water for $1 \mathrm{~min}$. Stir.

(2) Add Sr carrier, stir and cool in ice bath centrifuge, withcran the supernatant. ( $5 \mu$ gms of $\mathrm{Sr}^{++}$produoe visible ppt) see remarks $\mathrm{ft}_{\mathrm{I}}$.

(3) Wash the ppt with $\mathrm{Na}_{2} \mathrm{C}_{2} \mathrm{O}_{4}(500 \mathrm{X})$, stirring up and then centrifuging and discarding the was $\mathrm{h}$ in' $\mathrm{n}$.

(4) Ropeat wash 3 times.

(5) Fash with $\mathrm{H}_{2} \mathrm{O}(500 \lambda)$ twioe (aee remarks) $\# 2$.

(6) Dissolvo the ppt in $100 \lambda 11.0 \mathrm{M}-\mathrm{HClO}_{4}$. Heat. Add $5 \mathrm{\mu}$ gms $\mathrm{Rb}^{+}$, atir, $\infty 01$ in ice bath and centrifuge? This gives the Sr practically oarrier free in 100 , of sol'n.

\section{Bonarles:}

(1) and (2) While $5 \mathrm{y}$ of of $\mathrm{Sr}^{++}$produce a visible ppt as atated when washed with $1 \mathrm{ml}$ of $\mathrm{H}_{2} 0,25 \%$ of the ppt will dissolve.

(3) If carrier free $\mathrm{Sr}^{++}$is desired, $10 \mathrm{\mu}$ ems of $\mathrm{Ba}^{++}$carrier may be addod instead in step (2). The ppt is not washed but is dissolved in 0.1 I HCl and placed on a 2 min diaweter ion exchange column, $\mathrm{2}^{\circ}$ lopge The $\mathrm{Sr}^{++}$oomes off well after the $\mathrm{Rb}^{+}$. (Flow rate of ( 2 drop $/ 2.5$ min.)

$8 \times \mathrm{CO}_{3}$ arries $\mathrm{Rb}$ with it in largo quantities. 


\section{CHEMICAL SEPARATIOHS}

Eloment separatod: Strontium

Target material: $\sim 4$ \& U motal

Typo of bbdt: 184" all high onorgy particlos
Prooodure by: Folgor \& Hicks

Timo for sop'n: 1-2 hrs.

Equipment required: Contrifugo, tubos, 100, vaoulm desicoator

Yiold: 80\%

Dogroo of purification: Decontamination faotor $\sim 10^{4}$ from fission and spallation products. Sr docontaminatod $>100$ from $\mathrm{Ba}$.

Advantagos: Good yicld of Ba \& Sr, separntion from all other olomonts oxcopt Ra, very good soparation of $\mathrm{Sr} \& \mathrm{Ba}$ from oach othor, and $\mathrm{Sr}$ from Ra (which follows $B a$ ).

Prooodure :

(1) To c.liquot of $\mathrm{ENO}_{3}$ soln of targot ggntaining $10 \mathrm{mg}$ ocoh Sr \& Ba, and roduced in volumo to $1.5 \mathrm{ml}, 9 \mathrm{gl}-13 \mathrm{ml}$ fuming $\mathrm{BrO}_{3}$, digest cold 5 min.

(2) Dissolve ppt in $1 \mathrm{ml} \mathrm{H}_{2} \mathrm{O}$ \& reppt with $\sim 13 \mathrm{ml}$ fuming $\mathrm{Hor}_{3}$.

(3) Dis solvo ppt in $5 \mathrm{ml} \mathrm{H}_{2} \mathrm{O}$, add $2 \mathrm{mgFo}^{+3}$, and $\mathrm{ppt}+\mathrm{FO}_{\mathrm{O}}(\mathrm{OH})_{3}$ with tank $\mathrm{NH}_{3}\left(\mathrm{CO}_{3}\right.$ freol) Ropent $\mathrm{Fo}(\mathrm{OH})_{3}$ soav. (1 mg. $\mathrm{Fo}^{+3}$ ).

(4) Neutralizo supn with conc. HNO to mothyl orange ond point, add $1 \mathrm{ml}$ $6 \mathrm{M} \mathrm{Hhc} 2 \mathrm{ml}^{6} \mathrm{M} \mathrm{NH} \mathrm{NC}_{4}$. Heat to bolling \& add $1 \mathrm{ml} 1.5 \mathrm{H} \mathrm{Ha}_{2} \mathrm{CrO}_{4}$ dropwiso with stirring. Digest one min. (Savo the supn for Sr fraction).

(5) Ppt $5 \mathrm{mg} \mathrm{BaCrO}$ soav from oupn savod from Ba scpn. $\Lambda$ dd $2 \mathrm{ml}$ cono. $\mathrm{NH}_{4} \mathrm{OH}$, hôt, and ppt $\mathrm{SrCO}_{3}$ by adding satd $\mathrm{Na}_{2} \mathrm{CO}_{3}$. Digest 2 min, contrifugo and dissolvo $1 n^{3} 6$ I HCl (minimum). ${ }^{3}$ il out $\mathrm{CO}_{2}$.

(6) Nake basio with $\mathrm{MI}_{3}$ and add satd $\mathrm{Na}_{2} \mathrm{C}_{2} \mathrm{O}_{4}$. Stir 2 min (hot), cool, filter, wrsh three times wi th ${ }^{2} \mathrm{~m}^{2} \mathrm{H}_{\mathrm{g}} \mathrm{O}$, throo timos with $5 \mathrm{mI}$ EtOH, throo timos with $5 \mathrm{ml}$ othor, dry like $\mathrm{Bel}_{2}$. Jolgh as $\mathrm{SrC}_{2} \mathrm{O}_{4} \cdot \mathrm{H}_{2} \mathrm{O}$ (22.1 mg por 10 ms $\mathrm{Sr}$ ).

Romark: Procodurc adaptod for uso when $S_{Y}$ activity much groator than Ba.

Ra follows the Ba woll, can be separatod from it by use of a rosin oolume. Soo AECD 1998 (Edrard R. Tompldns)

For Ba sop'n from samo targot $800.56-1$.

In step (4) add 1 drop No-orango to tho 8 ol 'n bofore neutralization starts.

$8 / 12 / 49$

$P=18-152$ 
G BMTCAL SEPARATIONS

Bloment separatod: Strontium

Target material: Au foil, about $1 \mathrm{~g}$

Typo of bbdt: Full energy protons, holium ions, or douterons
Prooodure by: Lippmam and Goookermann

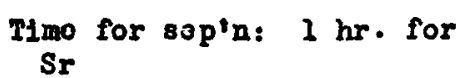

Equipmont roquirod: Ico bath and hot water bath

Yield: $\operatorname{sr} 50 \%$

Degres of purifloatign: Good - about $10^{5}$ from Au and spallation products and at loast $10^{3}$ from fission products.

Advantagos: Sr, Ba and Ib oan all bo soparated from tho samo target material.

Prooeduro:

Dissolve targot in hot solution contrining $10 \mathrm{mg}$ oach of $\mathrm{Sr}$, Ba, and 10. $5 \mathrm{ml}$ of $12 \mathrm{Y}$ HCl and $5 \mathrm{ml}$ of fuming $\mathrm{HNO}_{3}$. Cool solution in ico bath and olowly add about $30 \mathrm{ml}$ fuming $\mathrm{FNO}_{3}{ }^{\circ} \mathrm{Sr}\left(\mathrm{NO}_{3}\right)_{2}$ and $\mathrm{Ba}\left(\mathrm{NO}_{3}\right)_{2}$ preoipl tate. Contrifugo.

Dissolvo procipitato in $5 \mathrm{ml} \mathrm{H}_{2} \mathrm{O}$, add $5 \mathrm{mg}$ Fe III, warm in hot wator bath, and pleqipitate $\mathrm{Pe}(\mathrm{OH})_{3}$ with $6 \mathrm{M} \mathrm{NH}_{4} \mathrm{OH}$. Centrifuge. If dosired add moro $\mathrm{Fo}$ and centrifugo out $\mathrm{Fo}\left(\mathrm{OH}_{3}\right)_{3}{ }^{\mathrm{again}}$. Noutralizo supernatant with a fow drope of $6 \mathrm{H} \mathrm{HC}, \mathrm{H}_{3} \mathrm{O}_{2}$, hoat to boiling, and add $2 \mathrm{ml}$ of $1.5 \mathrm{H}$ $\mathrm{Ma}_{2} \mathrm{CrO}_{4}$ dropwise. Digost $\mathrm{BaCrO}_{4}$ proolpitato in hot wator bath and contrifuge.

Heat supernatent from flrst BaCro, procipitation to boiling, add $1 \mathrm{ml}$ of Ba oarrier dropwiso, digost in hot water bath, and contrifuge. To supernatent add $2 \mathrm{ml}$ of $15 \mathrm{~N} \mathrm{NH}_{4} \mathrm{OH}$ (oolor of solution should just ohange from oxango to yollow). Hoat to bolling, add $5 \mathrm{ml}$ seturatod ( $\left.\mathrm{Fi}_{4}\right)_{2} \mathrm{C}_{2} \mathrm{O}_{4}$ dropwise, digest in hot water bath, 0001, filtor, wash throe tims with $5 \mathrm{ml} \mathrm{H}_{2} 0$, throe timos with $5 \mathrm{ml}$ aloohol, and throo timos with $5 \mathrm{ml}$ othor. ${ }^{\mathrm{Dry}}$ in a vacuum dosicostor by pumping 2 minutos, lotting in air, and thon pumping for 5 more minutes. Meigh as $\mathrm{SrC}_{2} \mathrm{O}_{4} \cdot \mathrm{H}_{2} \mathrm{O}$.

Rowaxk:

A11 additions of fuming or conoontrated Hio should bo mado oautiously: they tend to roaot violontly aftor a short induction poriod. 
CHEMICAL SEPARATIONS

Bloment separated: Strontium

Targot matcrial: Thorium motal $(.1-1 \mathrm{gm})$

Typo of bbdt: 60" alphas
Procoduro by: Fowton

Timo for sep'n: $1 \mathrm{hr}$.

Eguipmont rcquired: Standard

Yiold: $75 \%$ on $\mathrm{Sr}$

Degrco of purification: $10^{6}$ other F.P. $\sim 10^{3}$ from bartues

Advantages: $\mathrm{Ba}$ and $\mathrm{Sr}$ can be takon out in samo procoduro.

Procedure: The Th motal is dissolvot in cono BCl plus a fow drops of $.2 \mathrm{li}\left(\mathrm{NH}_{\mathrm{A}}\right)_{2} \mathrm{SiF}_{6}$ to clear up tho black residuo. Tho $\mathrm{BCl}$ is diluted to $2 \mathrm{~N}$ and an alliquot takon.

(1) $\triangle d d 20 \mathrm{mg}$ cach $\mathrm{Ba}$ and $\mathrm{Sr}$ carrier and $30 \mathrm{ml}$ fuming nitric acid. Cool 1-2 minutos with stirring and contrifugo. (If $\mathrm{SO}_{4}$ prosont add $\mathrm{H}_{2} \mathrm{SO}_{4}$ to ppt BaSO . Tash with $10 \mathrm{ml} \mathrm{H}_{2} \mathrm{O}$. Hotathesizo with $60 \% \mathrm{~K}^{2} \mathrm{CO}_{3}^{4}$ by bolling 5 min. Contrifuge, whs with water. Dissolve ppt if $1^{3} \mathrm{~N}_{\mathrm{HHO}}$. Disoard rosidue. Then make fuming nitrio acid pptn.)

(2) Dissolvo ppt in $2 \mathrm{ml} \mathrm{H}_{2} \mathrm{O}$. Re-prooipitate with $15 \mathrm{ml}$ fuming $\mathrm{BNO}_{3}$ -

(3) Dissolve ppt in 5 to $10 \mathrm{ml} \mathrm{H} \mathrm{H}_{2}$. Add $5 \mathrm{mg} \mathrm{Fo}{ }^{+++}$, ppt $\mathrm{Fo}(\mathrm{OH})_{3}$ by adding $2 \mathrm{ml}$ corbonate free $6 \mathrm{~W} \mathrm{NH}$ OH or pass in $\mathrm{NH}_{3}$ gas to ppt $\mathrm{Fo}(\mathrm{OH})_{3}$. Contrifugo.

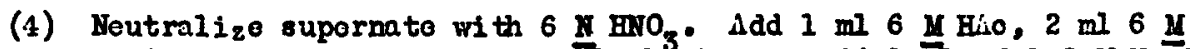
$\mathrm{NH}_{4} \mathrm{Ao}$. Hoat solution to noarly boiling. Sdd 1 ml of $1.5 \mathrm{y} \mathrm{Na}_{2} \mathrm{CrO}_{1}$ drópwiso with stirring. Lat stand 1 min. Contrifugo. Rošrvo supernate for $\mathrm{Sr}$.

(5) To oloar supornate add $2 \mathrm{ml}$ cono $\mathrm{NH}_{4} \mathrm{OH}$. Hoat nearly to boiling. Add 5 ml saturated ammonium oxalato slowly with sti rring. Stir 1-2 min., flltor with suction into a wolghod filter papor. Wash throo timos with $5 \mathrm{ml}$ dil hot $\mathrm{NH}_{4} \mathrm{OB}$, throo times with $5 \mathrm{ml} 95 \%$

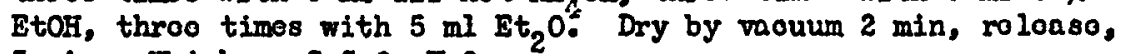
5 min.. Hoigh a.s $\mathrm{SrC}_{2} \mathrm{O}_{4} \cdot \mathrm{H}_{2} \mathrm{O}$.

Romarks: This prooodure has becn described proviously (Phys. Rov. 7517 (1919)).

For soparation of Ba from this prooodure seo (56-7).

Preparation of oarrior solution: Dissolve $2.4 .1 \mathrm{gms}$ of $\mathrm{Sr}\left(\mathrm{NO}_{3}\right)_{2}$ in water and diluto to 1 litor.

Standardization: Take $5 \mathrm{ml}$ oarrior add $30 \mathrm{ml} \mathrm{H}_{2} \mathrm{O}$. Add $5 \mathrm{ml}$ saturatod oxalio acid and heat nearly to boiling. Ldd $2 \mathrm{ml}$ conc $\mathrm{NH}_{\mathrm{h}} \mathrm{OH}$ dropwise with stirring. Lot 8 tand 10 minutos, cool in tap wator. Fil tôr into a sintorod glass oruoible. Thash 3 timos with hot wator containing a slight amount of $\mathrm{NH}_{4} \mathrm{OH}$, throo timos with $95 \% \mathrm{EtOH}$ and threo timos with $5 \mathrm{ml}$ portions $\mathrm{Bt}_{2} \mathrm{O}$. Evacuáto in vao dostcoator for 2 min., rolease vao and evacuato five minutoss longor and weigh as $\mathrm{SrC}_{2} \mathrm{O}_{4} \cdot \mathrm{H}_{2} \mathrm{O}$. Ropeat ovaovations until wolght constant to 0.2 mo 107

$P=18-281$ 
CHEXYICAL STPARATIONS

Element separated: Yttrium (Y-group rare earths) Proceduro by: Goockermann

Target material: $\backsim 1 \varepsilon B i$ metal

Time for sop'n: $\mathrm{n}^{2} \mathrm{hrs}$.

Typo of bbdt: 184" all particles

Equipment roquired: Contriruge, tubes, 100, vaouum dessioator, tank $\mathrm{SO}_{2}$ \& $\mathrm{NH}_{3}$

Y1eld: $\cap 70 \%$

Degrec of purifioation: Decontamination factor $\backsim 10^{4}$ from non-RE fission \& spallation products, Y-group separation from La-group probably fair.

Advantages: Designed to separate a lot of $Y$ aotivity from a hot target whioh has little rare earth activity, especially Y-group $R E$.

Procedure:

(1) To aliquot of $\mathrm{HNO}_{3}$ soln of target, add $10 \mathrm{mg} \mathrm{Y}, \mathrm{Ia}, \infty, \& \mathrm{Z}$, make $2 \mathrm{~N}$ in $\mathrm{HCl}$, $\mathrm{Z}$ add $2 \mathrm{ml}$ oonc. $\mathrm{HF}$. Wash ppt with $10 \mathrm{ml} 1 \mathrm{H}$ HCl containing HF.

(2) Dissolve in $1 \mathrm{ml}$ sat $\mathrm{H}_{3} \mathrm{BO}_{3} \& 8 \mathrm{ml}$ cono $\mathrm{HrO}_{3}$. Sdd $0.2 \mathrm{~g} \cdot \mathrm{KBrO}_{3}$

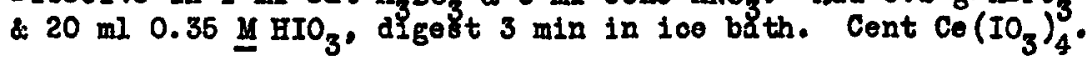

(3) Add scoond portion $\mathrm{KBrO}_{3}$ to supn, $10 \mathrm{mg}$ Ce \& $\mathrm{Zr}$, digest 5 min in ioo bath.

(4) Ldd $9 \mathrm{ml} 19 \underline{\mathrm{NaOH}}$ to supn. Wash ppt with $\mathrm{H}_{2} \mathrm{O}$.

(5) Dissolve ppt in I $\mathrm{ml}$ cone $\mathrm{HCl}$, dil to $8 \mathrm{ml}$, roduoe with $\mathrm{SO}_{2}$. Ppt hydroxides with $\mathrm{NH}_{3}$ \& wash with slightly allouline $\mathrm{H}_{2} \mathrm{O}$.

(6) Dissolve in $\mathrm{HCl}$ \& $8 \mathrm{cav}$ with $\mathrm{Bi}_{2} \mathrm{~S}_{3}$ twice.

(7) Boil out $\mathrm{H}_{2} \mathrm{~S}$, make $2 \mathrm{~N}$ in $\mathrm{H}^{+}$\& add $2 \mathrm{ml}$ oono. BF. Wash with H

(8) Wotathesize with pellot $\mathrm{NaOH}$ in a little $\mathrm{H}_{2} \mathrm{O} \&$ wash hydroxide ppt (watoh out for peptizationl) Dissolve in HCl \& ovap to dryness. Add $3 \mathrm{ml} 50 \% \mathrm{~K}_{2} \mathrm{CO}_{3}$ \&eat to dissolve ppt. Add $20 \mathrm{ml} \mathrm{H}_{2} \mathrm{O}$ \& hoat, until gelatinous ppt bocomes orystalline (ocours suddenly after long heating), then 2 min longor. Cent la-group ppt.

(9) Acidify supn with $\mathrm{HCl}$, ppt $\mathrm{Y}(\mathrm{OH})_{3}$ with $\mathrm{NH}_{3}$, \& wash twioe with $\mathrm{H}_{2} \mathrm{O}$. (kay repeat la-group soparation)?

(10) Dissolvo $\mathrm{Y}(\mathrm{OH})_{3}$ in $1 \mathrm{ml} S \mathrm{~N} \mathrm{HCl}$, add $15 \mathrm{ml} \mathrm{H} \mathrm{H}_{2} \mathrm{O}$, boil, add $15 \mathrm{ml}$ sat $\mathrm{H}_{2} \mathrm{C}_{2} \mathrm{O}_{4}$, digest 10 min In ice bath, filtor, wash with $3 \mathrm{ml}$ II $_{2}$, threo times with $5 \mathrm{ml}$ EtOH, threo times with 5 ml ether, dry in vacurum dessicator -- 2 min. evao, release, 2 min evao, release, 2 min ovao. Teigh as $\mathrm{Y}_{2}\left(\mathrm{C}_{2} \mathrm{O}_{4}\right)_{3} \cdot 10 \mathrm{H}_{2} \mathrm{O}$ (35.0 mg por $10 \mathrm{mg} \mathrm{Y}$ ). 
Romarka, Somotimes no soparation from Ce or La-group aotivitios was mado In the bismuth fission work. Real separations of $Y$ and the lanthanides oan be done with resin colums. 
Element separatod: Yttrium:

Targot marial: Sb ( N.5 gotal)

Type of bbdt: $184 " D_{2} \&$ a
Procoduro by: Lindnor

Time for sep'n: 2 hour

Equipment required: Lus to ro id tubes, contrifugo, cones

Yield: $\sim 95 \%$

Degree of purification: At least faotor of 100

Procedure:

(1) To dissoive the Sb motal, add 15 drops of $27 \mathrm{IIFF}$ to it in a lustoroid tube in a hot water bath. Add oono $7 \mathrm{~m}_{3}$ dropwise until dissolved ( $\sim 10 \mathrm{~min}$ ). Dilute to $\sim 20 \mathrm{ml}$.

(2) To the $56 \mathrm{~F}^{-}$solution add $20 \mathrm{mg}$ each of $\mathrm{Te}, \mathrm{Sn}, \mathrm{In}, \mathrm{Cd}, \mathrm{Af}$, $\mathrm{Pd}, \mathrm{Bu}, 10^{4}$ and $\mathrm{Y}$ oarriers as soluble salts. Add 2 drops conc ECl. Contrifugo the $\mathrm{YF}_{3}$ and $A g C l$ ppts.

(3) Wash the ppt with $1 \mathrm{IHF}$.

(4) Dissolve out the $\mathrm{Af}_{6}^{+}$from the ppt by adding $1 \mathrm{ml}$ cono. $\mathrm{MH}_{4} \mathrm{OH}$. Contrifuge.

(5) Dissolve the $\mathrm{YP}_{3}$ in $0.5 \mathrm{ml}$ sat $\mathrm{H}_{3} \mathrm{BO}_{3}, 1.0 \mathrm{ml}$ conc $\mathrm{BrO}_{3}$, on a hot water bath. Add, $5 \mathrm{ml} 6 \mathrm{~N} \mathrm{MaOH} \mathrm{and} \mathrm{contrifuge.}$

(6) Thash the $Y(\mathrm{OH})$ ppt with alkal ine 801 'n and dissolvo in ong drop oono. BCl. Dilute to $20 \mathrm{ml}$. Add 1 om $\mathrm{IBH}_{4} \mathrm{AO}_{\text {. Add } 2 \mathrm{mg}} \mathrm{In}^{++}$ soln. Saturate with $\mathrm{H}_{2} \mathrm{~s}$ and oentringe. "Disoa rd the $\mathrm{In}_{2} \mathrm{~s}_{3}$ ppt.

(7) Bo1l the supn to expel $\mathrm{H}_{2} \mathrm{~S}$. Add 3 drops $27 \mathrm{I}$ BF.

(8) Dissolve the $\mathrm{YP}_{3}$ ppt in $\mathrm{H}_{3} \mathrm{BO}_{3}-\mathrm{HWO}_{3}$ and ppt $\mathrm{Y}(\mathrm{OH})_{3}$ as in (5).

(9) Add $2 \mathrm{mg} \mathrm{SbCl}_{3}$ carrior to 101 'n. Saturate hot with $\mathrm{H}_{2} \mathrm{~s}$. Contrifugo.

(10) Disoa rd the $\mathrm{Sb}_{2} \mathrm{~s}_{3}$ ppt. Repeat the fluorido oyolo (7) \& (8).

(II) Dilute aliquot to $10 \mathrm{ml}$. Boil and add $5 \mathrm{ml}$ sat $\mathrm{H}_{2} \mathrm{C}_{2} \mathrm{O}_{4} \cdot$ Contrifuge out the $\mathrm{I}_{2}\left(\mathrm{C}_{2} \mathrm{O}_{4}\right)_{3} \cdot 10 \mathrm{H}_{2} \mathrm{O} \mathrm{ppt}$.

(12) Wash with $3 \mathrm{ml} \mathrm{B}_{2} \mathrm{O}$, thon $5 \mathrm{ml}$ BtOH, 3 timos with othor. Dry in

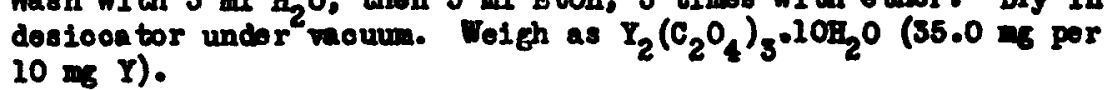

\section{$8 / 18 / 49$}


Element soparated: Yttrium

Target material: $\mathrm{SrCO}_{3}$

Typo of bbdti Protons 184"

Iield: $100 \%$ by radioaotivity (seo romarks)

Dogroe of purificction: < $1 \% \mathrm{Sr}$ carried with $Y$.

Adrantages: Crystalline ppt which 18 easier to centrifuge and/or filter than usual hydroxide ourds

Prooedure:

(1) Dis8olve $\mathrm{SrCO}_{3}$ in $\mathrm{YCl}_{3}$ soln containing $\mathrm{H}^{+}$suffioient to dissolvo the carbonate $\left(1 / 3 \mathrm{mg} / \mathrm{ml}\right.$ of $\left.\mathrm{YCl}_{3} \& \mathrm{H}^{+}=.025 \mathrm{H}\right)$.

(2) Add $1 / 2$ vol of soln made as follows: $0.17 \mathrm{mg}$<smiles>c1ccc2ccccc2c1</smiles>

(8 hydroxy

quinoline) dissolved in $12.5 \mathrm{ml}$ of a.oetone diluted to $50 \mathrm{ml}$ with $\mathrm{H}_{2}$. (turns yellow due to acldity of distilled $\mathrm{H}_{2} \mathrm{O}$ ). Stir.

(3) Add oono $\mathrm{NH}_{4}$ OH dropwise until odor of $\mathrm{MH}_{3}$ oan be deteoted above soln.

(4) Place in boiling water bath for 10 minutes, contrifuge. Yttrium will ppt as very finoly dividod grayish green orystals, Sr romains in soln. In ohemical yield runs $99 \%$ sp reooyored after yttrium was ppt. $Y$ ppt may be dissolved in $\mathrm{H}^{+}$or $\mathrm{H}^{+}+$acetono.

Romarks:

(1) On a second ppt of $Y$ from Sr bombardmont by abovo mothod no aotivity ( $30 \% / m$ abovo bagkeround) was detootod in I frection. Initial $Y$ fraction had $>10^{\circ} \mathrm{a} / \mathrm{m}$ in $108 \mathrm{~s}$ than $2 \%$ of tho fraotion.

(2) All $Y$ rare earths carry with $Y$.

(3) Ho expt triod to see if lanthanum rare earths oarry or not.

(4) After the yttrium has been congulatod and contrifuged the soln, belng basio, is oolorless and olear. Miltoring through donso filter paper on a Hirsoh nuneI will also removo all ppt.

$8 / 16 / 49$

Po-18-251 
Elomont separated: Zirconium

Target material: 1 G Bi metal

Typo of bbdt: 184" all partiolos
Procoduro by: Coookermann

Time for sop'n: $1-2 \mathrm{hrs}$.

Equi pmont roquirod: Contrifugo, tubes, Iustoroid conos, ice. small porcolain oruciblo.

Yiold: $\sim 60 \%$

Dogroe of purification: Dooontamination frotor u $10^{4}$ from flesion and spallation produots (no Th \& negligible He activity prosont).

Advantages: Cood yicld of puro $2 x$, if no Hf activity prosont.

Prooodure:

(1) To aliquot of $\mathrm{EnSO}_{\mathrm{g}} \mathrm{soln}$ of targot, add $10 \mathrm{mg} \mathrm{Zr}$, mako samplo up to $\mathrm{A} 5 \mathrm{ml}$ of $5 \mathrm{I}^{\mathrm{HTOO}}$ in a lus to rold oono. Add $2 \mathrm{ml}$ conc. $\mathrm{HP}$ 4 10 La. Ropont LRP 3 Ppta.

(2) Add 50 mg to supp. Thesh $\mathrm{ZrF}_{6}$ ppt.

(3) Dissolvo ppt in $2 \mathrm{ml} 5 \% \mathrm{H}_{3} \mathrm{BO}_{3}$, add $1 \mathrm{ml} \mathrm{cono.} \mathrm{HNO}_{3}$. ml $\mathrm{H}_{2} \mathrm{O}$, repoat LaF $_{3}$ Pptn trico (as in (1) and (2)).

(4) Ropoat BazrF 6 ptrn.

(5) Dissolvo with $2 \mathrm{ml} \mathrm{H} \mathrm{BO}_{3}, 2 \mathrm{ml}$ cono. $\mathrm{BCl}, \& 6 \mathrm{ml} \mathrm{H}_{2} \mathrm{O}$. Add 1 drop cono $\mathrm{H}_{2} \mathrm{SO}_{4}$ \& ocnt out $\mathrm{BHSO}_{4}$.

(6) Dil supn to $20 \mathrm{ml}$ add $2 \mathrm{ml} 6 \%$ oupforron in 100 bath, filter, wash with oold $1 \mathrm{~N} \mathrm{BCl}$ oontaining cupforron, ignito in a poroolain c ruoiblo. Toigh as $2 \mathrm{rO}_{2}$ (13.5 mg por $20 \mathrm{mg} \mathrm{Zr}$ ).

Romarks: This procoduro probebly offocts no soparation from Hf. In I don't know about. $\mathrm{Zr}$ can be suparatod from Hf by the use of TTA or antion oxohange resins. 


\section{CHEMICAL SEPARATIOMS}

Elemont separated: 21roonium

Targot material: Thorium motal $(.1-1 \mathrm{gm})$

Type of bbdt: 60" alphas

Yiold: $\sim 60 \%$
Prooodure by: Hewton

Timo for sop'n: 1-2 hrs.

Equipment required: standard

Prooedure: The Th metal is dissolrod in oone HCl plus a few drops of .2 $\mathrm{y}$ $\left(\mathrm{NH}_{4}\right)_{2} S 1 F_{6}$ to olear up the black residue. The HCl is diluted to 2 If and an aliquot taken.

(1) Use a lusteroid tube, add $\mathrm{HrO}_{3}$ to make $5 \mathrm{mll}$ of $\mathrm{soln}_{\mathrm{n}} 4$ to 5 molar in $\mathrm{HrO}_{3}$. Add $20 \mathrm{mg} \mathrm{Zr}$ carrier, $2 \mathrm{ml}$ o ono $\mathrm{HF}$ and $\mathrm{mix}$ woll. Centrifuge off $\mathrm{ThF}_{4}$.

(2) Add $10 \mathrm{mg} \mathrm{fa}^{+++}$oarrier. Mix well and contrifuge. Add a second $10 \mathrm{mg} \mathrm{La}^{\mathrm{t+}+}$ and centrifuge down on top of lst ppt. Deount.

(3) Add $50 \mathrm{mg} \mathrm{Be}{ }^{++}$to supn. Max and lot $8 \operatorname{tand} 1 \mathrm{~min}$. Contrifugo.

(4) Dissolwo ppt by adding $2 \mathrm{ml} 5 \% \mathrm{~B}_{3} \mathrm{BO}_{3}$ and stirring Add $1 \mathrm{ml}$ cono $\mathrm{HNO}_{3}$ and $5 \mathrm{ml} \mathrm{H} \mathrm{O}$. Add $2 \mathrm{ml} 27 \mathrm{NHF}^{3}$ and $50 \mathrm{mg} \mathrm{Ba}$. Stir until ppt forms and lót stand 1 minute longor.

(5) Repert (4).

(6) Dissolve with $2 \mathrm{ml} \mathrm{H}_{3} \mathrm{BO}_{3}, 2 \mathrm{ml}$ cono $\mathrm{HCl}$ and $5 \mathrm{ml} \mathrm{H}_{2} \mathrm{O}$. Add 1 dro oono $\mathrm{H}_{2} \mathrm{SO}_{4}$ and contrifuge off $\mathrm{BaSO}_{4}$.

(7) Transfer supernato. Dilute to $20 \mathrm{ml}$ and ppt $\mathrm{Zr}$ at 100 temp with $2 \mathrm{ml} 6 \%$ cupferron reagent. Centrifuge. Whas ppt with $1 \mathrm{ml}$ cold HC1 containing a rew drops of oupferron. Filter at onoe.

(8) Ignite ppt to $\mathrm{ZrO}_{2}$ in poroelain oruoible. Meigh.

Remarles: This prooedure has been described proviously. (Fhys. Rev. 75 17(1949)).

Preparation of carrier solutions: Dissolve $29.40 \mathrm{gms} 2 \mathrm{rO}\left(\mathrm{HO}_{3}\right)_{2} \cdot 2 \mathrm{H}_{2} \mathrm{O}$ in wator, adding a fow drops of $\mathrm{ENO}_{3}$ if necessary to olarify the golution. Dilute to 1 ifter.

Standardization: Take $5 \mathrm{ml}$ carrier. Take $2 \mathrm{M}$ in HCI and 0001 in 10e bath to $10^{\circ} \mathrm{C}$. Add a elight exoess of $6 \%$ oupferron solution. Filter and ignite in a poroelain oruoible with oare to prevent splattering of oils distilled from oupferron. Fimal ignition temper a ture $600^{\circ} \mathrm{C}$. Wigh as $\mathrm{ZrO}_{2}$. (6\% oupferron solution: $6 \mathrm{gms}$ oupferron and pinoh of $\left(\mathrm{HB}_{4}\right)_{2} \mathrm{CO}_{3}$ in $100^{2} \mathrm{ml} \mathrm{B}, \mathrm{B}^{2}$ Solution slowly decomposes.)

$8 / 23 / 49$

P-18-292 
Elomont separatod: Columbium

Dargot matorials in 1 g BI motal

Typo of bbdt: 184" all particlos
Proooduro by: Goockormann

Timo for sop'nt in 2 hre.

Bquipmont roquirod: Contrifugo, tubos, 100. Iusteroid conos. oruoible

Yiold: approx. 50\%

Dogrco of purifloation: Docontamination faotor $>10^{3}$ from fiasion \& sallation products.

Idvantages: Fair yicld of pure $\mathrm{Cb}$

Proceduro:

1. Add oqual volume of conocntrated $\mathrm{EHO}_{3}$ to aliquot of $\mathrm{HrO}_{3}$ soln of targot, $1 \mathrm{ml} 6 \mathrm{~N} \mathrm{HCl}, 1 \mathrm{ml}$ saturated fi, $\mathrm{C}_{2} \mathrm{O}, 20 \mathrm{mg} \mathrm{Cb}$, ald $10 \mathrm{mg}$ $\mathrm{Zr}$. Heat and add $0.5 \mathrm{~g} \mathrm{KBrO}_{3}$ in small portions. Digost 5 min. and oontrifuge $\mathrm{Cb}_{2} \mathrm{O}_{5}$. Fash prooipitato hot with $3 \mathrm{ml}$ 6I $\mathrm{HOO}_{3}$. $2 \mathrm{ml} 6 \mathrm{I} \mathrm{NH}_{4} \mathrm{OH}$, and $5 \mathrm{ml} \mathrm{H} \mathrm{H}_{2}$.

2. Dissolve in $1-2 \mathrm{ml}$ saturatod $\mathrm{H}_{2} \mathrm{C}_{2} \mathrm{O}_{4}+10$ drops $6 \mathrm{H} \mathrm{HCl}$. Whe up to $20 \mathrm{ml}$ of $6 \mathrm{I} \mathrm{HCl}, 0.05 \mathrm{M} \mathrm{H} \mathrm{SO}_{3}^{2}$ a fd add $10 \mathrm{ml} \mathrm{CHCl}_{\mathrm{g}}$. Cool in ico bath, add $2 \mathrm{ml}$ frosh $6 \%$ oupforron and shake woll. Bxtract a socond timc with moro $\mathrm{CHCl}_{3}$ and oupforron. Hash $\mathrm{CHCl}_{\mathrm{g}}$ with $20 \mathrm{ml}$ cold $6 \mathrm{~N} \mathrm{HCl}$ and $0.05 \mathrm{M} \mathrm{H}_{2} \mathrm{SO}_{3}$ containing moro cupforron.

3. Boil with $10 \mathrm{ml}$ conoontretcd $\mathrm{ENO}_{3}$, adding $\mathrm{KBrO}_{3}$ until $\mathrm{CECl}_{3} 18$ gono, solution is palc yollow and $\mathrm{Cb}_{2} \mathrm{O}_{5}$ has prooipititod.

4. Transfor to Iusteroid with dil. Hro H $_{3}$ Dissolvo by adding $1 \mathrm{ml}$ concentratod HF. Add $2 \mathrm{ml} 6 \mathrm{~N} \mathrm{HNO} \mathrm{s}^{\circ} 10 \mathrm{mg} \mathrm{Zr}$, and $5 \mathrm{ml} \mathrm{H} \mathrm{H}_{2}$ Add 50 ms Ba dropwiso and oontrifugo BazrF ${ }_{6}$

5. Add $6 \mathrm{al}$ concontratcd $\mathrm{MH}_{4} \mathrm{OH}$ to supornatant (to $\mathrm{pH} \mathrm{8-10).} \mathrm{Contrifugo}$

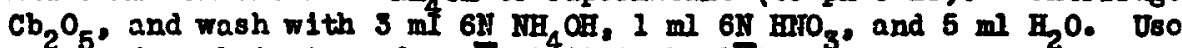
a sccond wash to transfor procipitato baok to glass.

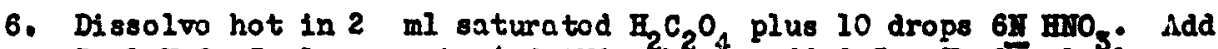

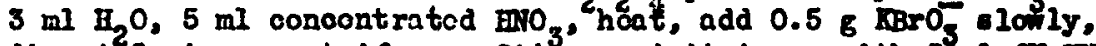
digest ${ }^{2}$ min., contrifuge. Stir prooipitato up with $3^{3} \mathrm{ml}$ Gi $\mathrm{miO}_{3}$. $2 \mathrm{ml} 6 \mathrm{~N} \mathrm{NH}$ aH, and $5 \mathrm{ml} \mathrm{H}_{2} 0$, hoat, fliter, ignito in a cruolblo $15 \mathrm{~min}$. Wéth as $\mathrm{Cb}_{2} \mathrm{O}_{5}$ (14.30 $\mathrm{mg}$ per $\left.10 \mathrm{mg} \mathrm{Cb}\right)$.

Romarks: Tho oxtrn is supposed to separato Cb from $\mathrm{Zr}$, To, \& $\mathrm{Ho}$.

Tho extrn soparation was substitutod for hoavy motal sulfide soav. to remove To and lio. The extrn proocduro oan poasibly bo oombinod with carrying of tho $\mathrm{Cb}$ tracor on $\mathrm{MhO}_{2}$ pptd from $10 \mathrm{I} \mathrm{HrO}_{3}$ for a carrier froo prooedure. 


\section{CHEMICAL SEP:RATIONS}

Eloment soparated: klybdonum

Target material: $\cap 1$ g Bi motal

Type of bbdt: 184" a.11 partiolos
Prooodure by: Gocckermann

Time for scp'n: $n 1 \mathrm{hr}$.

Equipment roquired: Contrifuge, tubes, $100,110^{\circ}$ oven

Yiold: approx. 50-80\%

Degreo of purification: Decontamination factor $>10^{4}$ from fission and spnllation products.

Ldvantagos: Good yiold of puro \$b

Procedurc:

1. Idd $10 \mathrm{mg}$ Lo c.nd ooncentrated $\mathrm{HCl}$ to aliquot of $\mathrm{ENO}_{3}$ soln of target, destroy $\mathrm{HIO}_{3}$. Nake up to $5 \mathrm{ml} 6 \mathrm{~N} \mathrm{HCl}$, add one drop $\mathrm{Br}_{2}$ wator, oxtract twido with $15 \mathrm{ml}$ other. Combino ether inyors and mosh twioo with $2 \mathrm{ml} 6 \mathrm{~N}$ HCl. Evaporate othor over $5 \mathrm{ml} \mathrm{H} \mathrm{H}$.

2. Boil out ether, dilute to $20 \mathrm{ml}$, add $5 \mathrm{mg} \mathrm{Fe}^{+3}$ cnd precipitate with $\mathrm{NH}_{3}$.

3. Ldd 6 ml conoontrated HNO $\mathrm{H}_{3}$ and $1 \mathrm{ml}$ saturated $\mathrm{H}_{2} \mathrm{C}_{2} \mathrm{O}_{4}$ to supornatant, 0001 , add $5 \mathrm{ml} 2 \%$ solution of abenzoin oximo in alcohol, digest 2 min., add acrosol and ocntrifuge $5 \mathrm{~min}$. (If the 16 oxime does not settle woll. dilute the solution with $\left.\mathrm{C}_{2} \mathrm{H}_{5} \mathrm{OH}\right)$. Wh twioe with $20 \mathrm{ml} 1 \mathrm{~N} \mathrm{HNO}_{3}$.

4. Add $2 \mathrm{ml}$ oonocntrated $\mathrm{HNO}_{5}$ and $\mathrm{I} \mathrm{ml}$ concontratod $\mathrm{HClO}_{4}$ and boil corefully to fuming. Cool, dilute to $15 \mathrm{ml}$ with $\mathrm{H}_{2} \mathrm{O}$, add $5 \mathrm{mg} \mathrm{Fo}$ and prooipitate with $\mathrm{NH}_{3}$.

5. Add 1 drop methyl orange to supernatant and make just acid with $6 \pi$ $\mathrm{H}_{2} \mathrm{SO}_{4}$. Buffor with $1 \mathrm{ml} 10 \% \mathrm{CH}_{3} \mathrm{COONa}$, boil, add 10 drops $2 \mathrm{M} \mathrm{AFNO}_{3}^{-}$, $0001^{*}$ lowly with stirring, filter, wash fivo timos with 5 mi $0.03^{\circ}$ II $\triangle \mathrm{gNO}_{\mathrm{g}}$, threc times with $5 \mathrm{ml} \mathrm{C}_{\mathrm{H}} \mathrm{OH}$, dry $15 \mathrm{~min}$. at $110^{\circ} \mathrm{C}$. Weigh os $\mathrm{Ag}_{2} \mathrm{HoO}_{4}(39.16 \mathrm{mg}$ per 10 ig 10$)$.

Romarka: Wre oyclos of cther extraction and oxino prooipitation my bo added if noedod for purity. 160 oximo ocn bo dissolvod oompletely by 61 Ho on \& ropptd by acidifyine \& adding moro a-bonzoin oxime. 
Elomont soparatod: Wlybdonum

Targot matorial: Au foil, about $1 \mathrm{~g}$

Yiold: $65 \%$
Prooodure by: Lippmann and Goookormann

Timo for sop'n: \& hr.

Equipmont roquirod: $I_{\text {co bath }}$ and hot water bath.

Dogrce of purifleatign: Good - about $10^{5}$ from $A_{u}$ and spallation produots and at loast $10^{3}$ from fiseion produots.

Advantages: Sr, $B a$ and Mo onn 2.11 be soparated from the samo targct material.

Proooduro: Dissolve target in hot solution containing 10 mg oach of Sr. $\mathrm{Ba}$, and $10,5 \mathrm{ml}$ of $12 \mathrm{~K} \mathrm{HCl}$ and $5 \mathrm{ml}$ of fuming Emo $\mathrm{g}^{\circ}$ Cool solution in 100 bath and lowly add about $30 \mathrm{ml}$ funing $\mathrm{EHO}_{3}{ }^{\circ} \mathrm{Sr}\left(\mathrm{MO}_{3}\right)_{2}$ and $\mathrm{Ba}\left(\mathrm{NO}_{3}\right)_{2}$ prooipitato. Contrifugo.

Heat suparnatont from prooipitation of $\mathrm{Sr}\left(\mathrm{HO}_{3}\right)_{2}$ and $\mathrm{Ba}\left(\mathrm{HO}_{3}\right)_{2}$ in wator bath to dostroy ECl. Cool in 100 both and sowly add $\mathrm{K}_{4}$ Fo (Cx) 60 sution unt1l no furthor preoipitato appoars. Contrifugc. Wash preolipitato with $10 \mathrm{ml}$ of $6 \mathrm{yHNO}_{3}$ oontaining a fow drops of $\mathrm{K}_{4} \mathrm{Fo}$ (CX) solution and oontrifugo again. Di8solvo prooipltato in $10 \mathrm{ml}$ of 6 y HCl with hoating. diluto to $30 \mathrm{ml}$ with aloohol, 0001 in $100 \mathrm{bath}$, and add $5 \mathrm{ml}$ of $2 \%$ solution of abonzoinoximo in aloohol. Contrifugo. Whoh proolpitato with $10 \mathrm{ml}$ aloohol and centrifugo again. Dissolvo proolpitato by slowly adding $4 \mathrm{ml}$ of $16 \underline{\mathrm{H}} \mathrm{mOO}_{3}$, hoating gontly in hot water bath whon roaotion slows down. Whon all of prociplta to has dis8olvod add 1 ml concontratod $\mathrm{EClO}_{4}$ and hoat oautiously ovor a flamo until thick, whito fums havo gquo off for sovoral minutos. Diluto to $15 \mathrm{ml}$ with $\mathrm{H}_{2} \mathrm{O}$,

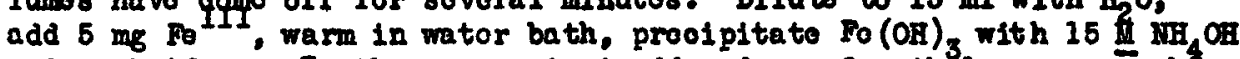
and contrifugo: To tho supornatont add a drop of mothy 1 orango, mako just aold with $6 \mathrm{Y} \mathrm{H}_{3} \mathrm{SO}_{4}$. buffor with $1 \mathrm{ml}$ of $1 \mathrm{~g} \mathrm{NaC}_{2} \mathrm{H}_{3} \mathrm{O}_{2}$, hoat to bolling, add 10 drops of 1 If $\mathrm{AgLO}_{3}$, digost in hot wats $\mathrm{S}^{\mathrm{S}}$ beth, 0001 , flitor, wash fivo timos with $6 \mathrm{ml}$ of $\mathrm{H}_{2} \mathrm{O}$ oontaining a fow drops of Ag $\mathrm{NO}_{3}$, flve times with $5 \mathrm{ml}$ aloohol, dry 15 minutes at $110^{\circ} \mathrm{C}$. Folgh as $\mathrm{Ag}^{3} \mathrm{HoO}_{4}$.

Romarke:

In ordor to destroy the lib a-bonzolnoxim tho solution mast bo hoatod until whito fumos havo boliod off for sovoral minutos. If all of tho a-boneoin oximo is not dostroyod, Wo ambaneoin oximo will roprooipitato whon tho solution 18 made basio.

All additions of fuming or conoentrated $\mathrm{BHO}_{3}$ should be made oautiously: thoy tond to reaot violently after a short induotion period. 


\section{Element separated: Molybdemm}

Target material: Thorium metal (.1-1 gm)

Type of bbdt: $60^{\prime \prime}$ a's

Yie Id: $\sim 60 \%$

Degree of purification: $\sim 10^{5}-10^{6}$

Advantages: The Th metal is dissolved in cono $\mathrm{HCl}_{1}+$ a few drops $2 \mathrm{M}$ solution $\left(\mathrm{NH}_{4}\right)_{2} \mathrm{SIF}_{6}$ to clear up black residue. The HCl is diluted to $2 \mathrm{~N}$ and an al iquot taken.

(1) Add $10 \mathrm{mg}$ ifo to sample in HCl. Add $\mathrm{Br}_{2}$ to oxidize No. 1ake $6 \mathrm{~N} \mathrm{HCl}$. Extract three times with double volume ether. Combine ether layers. Tash twico with $2 \mathrm{ml} 6 \mathrm{~N} \mathrm{HCl}$. Evajora to other over water. (lay repeat $\mathrm{Et}_{2} \mathrm{O}$ extraction after $\mathrm{Fe}(\mathrm{OH})_{3}$ scavenging.

(2) To evaporated solution add $5 \mathrm{ml} 6 \mathrm{~N} \mathrm{HNO}_{3}, 1 \mathrm{ml}$ sat $\mathrm{H}_{2} \mathrm{C}_{2} \mathrm{O}_{4}$ (complex $\mathrm{Cb}$ ), ppt by stirring with $5 \mathrm{ml} 2 \%$ a-benzoin oxime. (ppts $\mathrm{MO}^{4} \mathrm{Cb}$ \& $\mathrm{Pd}$ ). Let stand $2 \mathrm{min.}$, wash with $20 \mathrm{ml} 1 \mathrm{~N} \mathrm{HNO}_{3}$.

(3) Add $2 \mathrm{ml}$ cono $\mathrm{HNO}_{3}$ \& $1 \mathrm{ml} 70 \% \mathrm{HClO}_{4}$. Heat to fuming, cool, add $20 \mathrm{ml} \mathrm{H}_{2} \mathrm{O}$. Add $5 \mathrm{mg} \mathrm{Fe}$ \& $2 \mathrm{ml}$ cono $\mathrm{NH}_{4} \mathrm{OH}$. To supermato add $6 \mathrm{ml}$ coñe $\mathrm{HWO}_{3} \&$ re-ppt with $5 \mathrm{ml} \mathrm{a-b-0,}$ "wash. Repeat pptn of Fe for higher purity.

(4) Dissolve in $2 \mathrm{ml}$ oonc $\mathrm{ENO}_{3}$ \& $1 \mathrm{ml} 70 \% \mathrm{HClO}_{4}$ \& hoat to fuming. Dilute to $30 \mathrm{ml}$, add 1 drop methyl orange, "make just alkaline with 0.5 to $1 \mathrm{ml} 6 \mathrm{~N} \mathrm{NH}_{4}$ OH. Nake just acid with $6 \mathrm{~N} \mathrm{H} \mathrm{SO}_{4}$. Burfer with $2 \mathrm{ml} 10 \%$ Malc, boil, add $0.5 \mathrm{ml} 1 \mathrm{M} \mathrm{AgNO}$. 6001 with stirring. Filter, wash 7 times with $5 \mathrm{ml} 0.03 \mathrm{rAg}_{\mathrm{g}}$, three times with $5 \mathrm{ml}$ $95 \%$ EtoH. Dry $15 \mathrm{~min}$ at $110^{\circ}$. Cool in desicoator, Foigh as $\mathrm{Ag}_{2} \mathrm{MLO}_{4}$.

Remarks: This method has been previously described in (Phys. Rev. 7517 (1949)).

Wo oxime oan be dissolved completely by $\mathrm{NaOH}$ (6N) and repptd by adding acid and more $a-b-0$.

Stock solution of carrier - $18.4 \mathrm{~g}\left(\mathrm{MH}_{4}\right)_{6} \mathrm{MO}_{7} \mathrm{O}_{24} \cdot 4 \mathrm{H}_{2} \mathrm{O}$ in 1 I itor $\mathrm{H}_{2} \mathrm{O}$

To standardize oarrier: Put $5 \mathrm{ml}$ carrier in $250 \mathrm{ml}$ beaker. Add $150 \mathrm{ml}$ $\mathrm{H}_{2} \mathrm{O}$,methyl orange, several drops $6 \mathrm{~N} \mathrm{NH}_{4} \mathrm{OH}$ to alkaline, just aoid with $6 \mathrm{~N} \mathrm{H}_{2} \mathrm{SO}_{4}$. Add $1 \mathrm{gm} \mathrm{NaAc}$. boil, add $2.5 \mathrm{ml} 1 \mathrm{~N} \mathrm{AgNO}_{3}$, stir. Cool slowly to $25 \%$ C. Filter on tared sintered glass filte $\vec{r}$. Wh mentionod before.

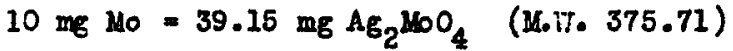

$8 / 23 / 49$

P-18-288 
CHMIICAL SIPARATIONS

Elemont separated: Blybdenum

Targot material: $\sim 4 \mathrm{~g}$ U motal

Type of bbdt: 184 " all high energy particles

Tield: Approx. 50-80\%
Prooodure by: Folger

Time for sepin: 2 hrs.

Equipment required: wide-mouth oylindrical sep. funnels, stirring motor and glass stirring rods, ico bath, contrifuge and cones

Degree of purification: $10^{4}$ from all F.P. activities

Advantages: Gives puro lib in good yield

Procedure: To aliquot of samplo in solution:

(1) Add $1.0 \mathrm{mg} \mathrm{No}$ and concentrated $\mathrm{HCl}$, destroy $\mathrm{HNO}_{3}$. Wake up to $5 \mathrm{ml}$ $6 \mathrm{~N} \mathrm{HCl}$, add one drop $\mathrm{Br}$, water, extraot twice with $15 \mathrm{ml}$ other a) Iowing $\sim 5$ min equilibration. Combine ether layers and wash twico with $2 \mathrm{ml} 6 \mathrm{NHCl}$. Evaporate ether over $5 \mathrm{ml} \mathrm{H}_{2} \mathrm{O}$.

(2) Bo1l out ether, dilute to $10 \mathrm{ml}$, add $2 \mathrm{mg} \mathrm{Fo}{ }^{+3}$ and $2 \mathrm{mg} \mathrm{Cb}$ (as oxalate) and precipitate with $\mathrm{IIH}_{3}$.

(3) Make supernatant $0.5 \mathrm{~N}$ in $\mathrm{HCl}$ and add $1 \mathrm{ml}$ saturated $\mathrm{H}_{2} \mathrm{C}_{2} \mathrm{O}_{4}$, cool. Add $3 \mathrm{ml} 2 \%$ solution of a-benzoin axime in alcohol, digest $2 \mathrm{mln}$. in ice bath, add aerosol and centrifuge $5 \mathrm{~min}$. (If the Mo oxime does not settle well, dilute the solution with $\mathrm{C}_{2} \mathrm{H}_{5} \mathrm{OH}$ ). Wesh twice with $2 \mathrm{ml} 0.5 \mathrm{~N}_{2} \mathrm{SO}_{4}$.

(4) Add $2 \mathrm{ml}$ concentrated $\mathrm{HiO}_{3}$ and $1 \mathrm{ml}$ concentrated $\mathrm{HClO} \mathrm{O}_{4}$ and boil cargfully to fuming. Cool, dilute to $10 \mathrm{ml}$ with $\mathrm{H}_{2} \mathrm{O}$, add $2 \mathrm{mg}$ $\mathrm{Fe}^{+3}$, and precipitate with 6 IN $\mathrm{NaOH}$.

(5) Ropoat (3) by making $0.5 \mathrm{~N}$ in $\mathrm{H}_{2} \mathrm{SO}_{4}$ ins toad of $\mathrm{HCl}_{1}$. Ropoat (4).

(6) Add 1 drop nethy 1 orange to supernatent and make just acid with $6 \mathrm{~N} \mathrm{H}_{2} \mathrm{SO}_{4}$. Buffer with $1 \mathrm{ml} 10 \% \mathrm{CH}_{3} \mathrm{COONa}$, boll, add 10 drops $1 \mathrm{M}$ $\mathrm{AgNO}_{3}$, cool slowly with stirring, filter, wash five times vith

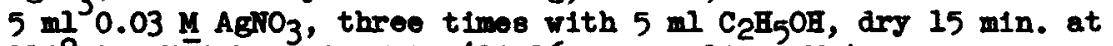
$110^{\circ} \mathrm{C}$. Wêlgh as Age $\mathrm{MOO}_{4}$ (39.16 mg per $10 \mathrm{mg} \mathrm{Mo}$ ).

Remarks:

(1) Wore oycles of other extraction and oximo precipitation may be added if noeded for purity.

(2) Wo-a-benzoinoxime can be completely dissolved in $6 \mathrm{~N} \mathrm{NaOH}$ and ro-pptd by making the soln $0.5 \mathrm{~N}$ in $\mathrm{F}^{+}$and adding $a-b-0$.

(3) Continued fuming with oone $\mathrm{HNO}_{3}$ and conc $\mathrm{HClO}$ will ppt a form of molybdio aoid whioh can be dissolvod readily in 6 I HaOH. 


\section{CTELACAL SAPARITIONS}

Elemont separated: Ruthonium

Targot matoriali M1 B B1 metal

Type of bbdt: 184" all partioles

Proooduro by: Goeckormann

Timo for sep'n: $\mathrm{h}^{2} \mathrm{hr}$.

Equipnont required: Distilling flask ice, contrifugo, tubos, $110^{\circ}$ ovon

Tiold: approx. $60 \%$

Degroo of purification: Docontamination factor $>10^{4}$ from fission and spallation products.

Sdrnntagcs: Fair yicld of puro ha

Proocduro:

1. Add 10 Ran and os to al iquot of $\mathrm{H}_{3} \mathrm{O}_{3}$ soln of targot, boil $6 \mathrm{~N}$ HNO ${ }_{3}$ solution to volatilize 030 . Trninsfer to glass st11l, add

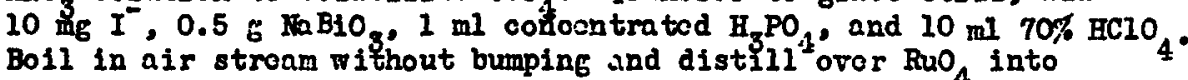
$12 \mathrm{ml} 6 \mathrm{~N}$ NaOH in an 100 bath. Distill until $1-2 \mathrm{ml}$ of $\mathrm{HCl}_{4}$ have distillod (2-3 min, after fuming bo-ins).

2. To distillato, add $3 \mathrm{ml} \mathrm{C}_{2} \mathrm{~F}_{5}$ OH and boil 1-2 min. until $\mathrm{Ru}$ oxido is coagulated. Thash with $10^{2} \mathrm{mi} \mathrm{H}_{2} \mathrm{O}$ and $1 \mathrm{ml} 6 \mathrm{~N} \mathrm{NaOH}$ and boil.

3. Dist1ll Puo, again, if nooossary, and reprocipitate oxido.

4. Dissolvo prcoipitato in $2 \mathrm{ml}$ hot $6 \mathrm{H} \mathrm{HCl}$ and diluto to $12 \mathrm{ml}$. Add $\sim 0.28$ rs ohips or ooarsc powdor slowly (add acrosol) until solution passes through bluo stago and Ri appoars. Boil gontly until ooagulatod. Add $5 \mathrm{ml}$ oonecntratod HCl to remoro oxocss 4 and boil, filter, wash throo timos with $5 \mathrm{ml}$ hot $\mathrm{H}_{3} \mathrm{O}$, threo timcs with $5 \mathrm{ml} \mathrm{C}_{2} \mathrm{H}_{5} \mathrm{CH}_{\text {, }}$ threc times with $5 \mathrm{ml}$ othor, ary $10 \mathrm{~min}$. at $110^{\circ}$ C. Woigh as $\mathrm{Ru}^{\circ}$.

Romarks: Somo $\mathrm{B}_{\mathrm{U}}$ may be lost from bolling a cono. Hro $801 \mathrm{n}$. Os if Tc do not ppt with the EtOH. The $\mathrm{BaBlO}_{3}$ oonverts I to lodate to prevont volatilization. The $\mathrm{H}_{3} \mathrm{PO}_{4}$ provents volatilization of small amounts of 10. 
CHBMICAL SEPARATIOKS

Eloment soparetod: Ruthonium

Thrget matorial: 4 G. U motal

Typo of bbdt: 184" all high cnorey partiolos

Yiold: approx. $60 \%$

Dogroo of purification: $\sim 10^{4}$ from all F.P. activities.

Advantarges: Fairly rapid, simple procoduro for obtrining a good yiold of Ru.

Procodure:

(1) Add $10 \mathrm{mg} \mathrm{Ru}$ and $0 \mathrm{s,}$ boll $6 \mathrm{~N} \mathrm{HNO}_{3}$ solution to volatiliso $05 \mathrm{~S}_{4}$ Transfor to glass still, add $10 \mathrm{mg} \mathrm{I}, 0.5 \mathrm{~g} \mathrm{NaBiO}, 5 \mathrm{mg}$ No holdback, $1 \mathrm{ml}$ conocntrsted $\mathrm{H}_{3} \mathrm{PO}_{4}$, and $10 \mathrm{ml} 70 \% \mathrm{HClO}_{4}$. Boil in air strosm without bumping and distill ovor RuO 1 itto $12 \mathrm{ml} 6 \mathrm{~N} \mathrm{NhOH}$ in an loc bath. Distill until 3-4 ml of $\mathrm{HCIO}_{4}$ havo distinlod (5 min. aftor fuming bogins).

(2) To distillato, add $3 \mathrm{ml} \mathrm{C}_{2} \mathrm{H}_{5}$ OH and boil 1-2 min. until Ru oxido is coagulatod. Wash with $18 \mathrm{ml} \mathrm{H} O$ and $1 \mathrm{ml} 6 \mathrm{~N}$ MOH and boil. (loavos To bohind).

(3) Distill $\mathrm{RuO}_{4}$ again, if noccssary, and roprccipitato oxide.

(4) Dissolvo procipitato in $2 \mathrm{ml}$ hot $6 \mathrm{~N} \mathrm{HCl}$ and diluto to $12 \mathrm{ml}$. (Twlo aliquot for counting hore if dosirod). Add $N 0.2 \mathrm{~g}$ Y chips or coarso powdor slowly (add norosol) until solution passes through bluo stage and Ru apponrs. Boil gently until cocgulatod. Add $5 \mathrm{ml}$ concontratod $\mathrm{HCl}$ to romovo oxooss $\mathrm{LS}$ and boil, filtor. wash throo timos with $5 \mathrm{ml}$ hot $\mathrm{H}_{2} \mathrm{O}$, throo timos with $5 \mathrm{ml} \mathrm{C}_{2} \mathrm{H}_{5} \mathrm{OH}_{8}$ threo times with $5 \mathrm{ml}$ other, dry $10 \mathrm{~min}$. at $110^{\circ} \mathrm{C}$. Folgh $\mathrm{cs}^{5} \mathrm{Ru}$. 
CHEUTCAL STPARATIONS

Element separated: Ruthenium

Target material: Sb ( $.5 \mathrm{gm}$ metal)

Type of bbdt: $184^{\prime \prime} D_{2} \&$ a

Yield: $50 \%$ or Ereater

Depree of purifloation: At least factor of 100

Prooeduro:

(1) To dissolvo tho Sb metal, add 15 drops of 27 II IF to it in a lusteroid tube in a hot wator bath. Add $00 n 0 \mathrm{ENO}_{3}$ dropwise until dissolved ( $10 \mathrm{~min}$.) Dilute to $\infty \mathrm{ml}$."

(2) To the SbF - solution add $20 \mathrm{mg} e a 0 \mathrm{~h}$ of $\mathrm{Te}_{\theta}, \mathrm{Sn}, \mathrm{In}, \mathrm{Cd}, \mathrm{Ag}_{\mathrm{g}}, \mathrm{Pd}$, $\mathrm{Ru}, 16$ and $\mathrm{H}^{4}$ oarriers as soluble salts. Add 2 drops oono. HCl. Contrifuge the $\mathrm{YF}_{3}$ and AgCl ppts.

(3) To half of the supn add $5 \mathrm{ml}$ of $1 \%$ dimethyl glyoxime in aloohol. Contrifuge.

(4) Place the supn on an 100 bath, add $5 \mathrm{ml} \mathrm{2 \%}$ a benzoln oxime ard digest 2 min. Centrifugo.

(5) Evaporate sup'n to noardryness on hot plate. Add $10 \mathrm{ml} \mathrm{H}_{2} \mathrm{O}, 2 \mathrm{ml}$ oonc. $\mathrm{H}_{2} \mathrm{SO}_{4}$ and evap to funing for $20 \mathrm{~min}$.

(6) Transfer to "Ru distilling slask", add $5 \mathrm{ml} 70 \% \mathrm{HClO}$. Boll to ruming for $10 \mathrm{~min}$, oatohing distillate in $5 \mathrm{ml} 6 \mathrm{~N}$ WeH.

(7) Add $2 \mathrm{ml}$ EtOH to the $\mathrm{RuO}_{4}$ in $\mathrm{KaOH}$, boll and contrifuge.

(8) Dissolve the $\mathrm{RuO}_{2}$ ppt in a minimum 6 I HCl.

(9) Add $5 \mathrm{ml} 70 \% \mathrm{HClO}_{4}$, Repeat steps 6-8.

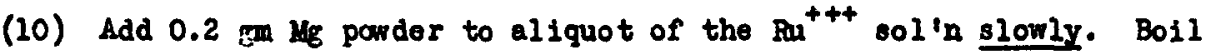
gently to ooagulate Ru.

(II) Add $5 \mathrm{ml}$ cono $\mathrm{HCl}$ to dissolvo exoess $\mathrm{Lf}$ and boil.

(12) Plate the Ru motal and oount.
$8 / 18 / 49$

P-18m222 
CHERICAL SEPARATIONS

Elemont soparated: Ruthenium

Procedure by: Newton

Targot matorial: Thorium motal $(.1-1 \mathrm{gm})$

Time for sop'ng $1 \mathrm{hr}$.

Iypo of bbdt: 60" al phas

Equipment requirod:

"Ruthonium still"

Y101d: $\sim 10^{6}$

Prooodure: The Th motal is dissolvod in cono HCl plus a fow drops of .2 M $\left(\mathrm{MH}_{4}\right)_{2} \mathrm{SiF}_{6}$ to oloor up tho blaok rosiduo. Tho $\mathrm{BCl}$ is diluted to $2 \mathrm{~N}$ and al aliquot takon.

(1) Placo aliquot in a distilling flask, add 20 me Ru oarrior, $10 \mathrm{mg} \mathrm{I}$ carrior, $0.5 \mathrm{gm} \mathrm{NaBiO}, 1 \mathrm{ml} 85,3 \mathrm{~B}_{3} \mathrm{PO}_{4}$ and $10 \mathrm{ml} 70 \%$ HC10. Hoat gontly to boiling and distill huthonilm rapidly, (arold bumping) into $12 \mathrm{ml}$ of $6 \mathrm{NN} \mathrm{NaOH}$ in a $50 \mathrm{ml}$ oentrifugo tube in an 100 bath. Distill tiil $1-2 \mathrm{ml}$ of $\mathrm{HClO}_{4}$ have distillod (1-2 min aftor fuming bogins).

(2) To distillato add $5 \mathrm{ml}$ EtOH. Hoat gontly to boiling by swirling ovor a flamo and oontrifugo. Suspond pptd $\mathrm{Ru}$ in $10 \mathrm{ml} \mathrm{H}, \mathrm{O}$ oontaining I ml of 6 M NaOH. Hoat to bolling and contrifugo.

(5) Dissolvo npt by heating to boiling in $2 \mathrm{ml} 6 \mathrm{M} \mathrm{HCl}$. Add $10 \mathrm{ml}$ $\mathrm{H}_{0} \mathrm{O}$. Add $0.2 \mathrm{gm}$ He powder in small portions, shaking with each addition. Add a few drops $0.1 \%$ aerosol to minimiso frothing. Boll gontly until Ru in woll ooagulatod. Continue boiling 2 min. slowly add $5 \mathrm{mI}$ of $12 \mathrm{Y}$ HCI to romove cxooss magnesium and again boil 2 min.

(4) Piltor by suction on a woighod filtor papor in a small Elrsoh cunnol. Plash throe times with 5 ml hot $\mathrm{H}_{2} \mathrm{O}$, throo times with $5 \mathrm{ml} 95 \%$ Btor, and throe times with $6 \mathrm{ml} \mathrm{Et}_{2} 0$. Dry $10 \mathrm{~min}$. at $110^{\circ}$. Wolgh as Ru०.

\section{$\boldsymbol{R}_{\text {cmarke : }}$}

Preparation of Carrior Solution: Dis80170 28 gns oomoroial ruthenium ohlorlde ( $\left.\left.\mathrm{RuCl}_{3} \mathrm{kuCl}_{4}\right)^{x} \mathrm{H}_{2} \mathrm{O}\right)$ in water and diluto to 1 litor.

Standardization: Tako $5 \mathrm{ml}$ carrior in $250 \mathrm{ml}$ orlonmoyer. Add $25 \mathrm{ml}$ $\mathrm{H}_{2} \mathrm{O}, 2 \mathrm{ml}$ oonc. HCl. had 0.4 gms powdorod magnosium motal in small portions, shaking aftor oach addition. dad a few drops $0.1 \%$ aeroso 1 801 to prevont frothing and boil gently till the suthenium is coagulated and the supernate olear and oolorioss. Continue to boil 2 min. Add $10 \mathrm{ml} 12 \mathrm{M} \mathrm{HCl}$ to romove oxcoss if and boil $2 \mathrm{~min}$. (Add morc if if supornato not clear). Filtor, wash throo times with hot $\mathrm{H}_{2} \mathrm{O}$, throo timos with $5 \mathrm{ml}$ portions EtOH, throo timos with $\mathrm{Et}_{2} \mathrm{O}$. Dry at $110^{\circ}$ and weigh as $\mathrm{Bu}$ metal.

This mothod has beon doscribod proviously (Phys. Bev. 7517 (1949)). 


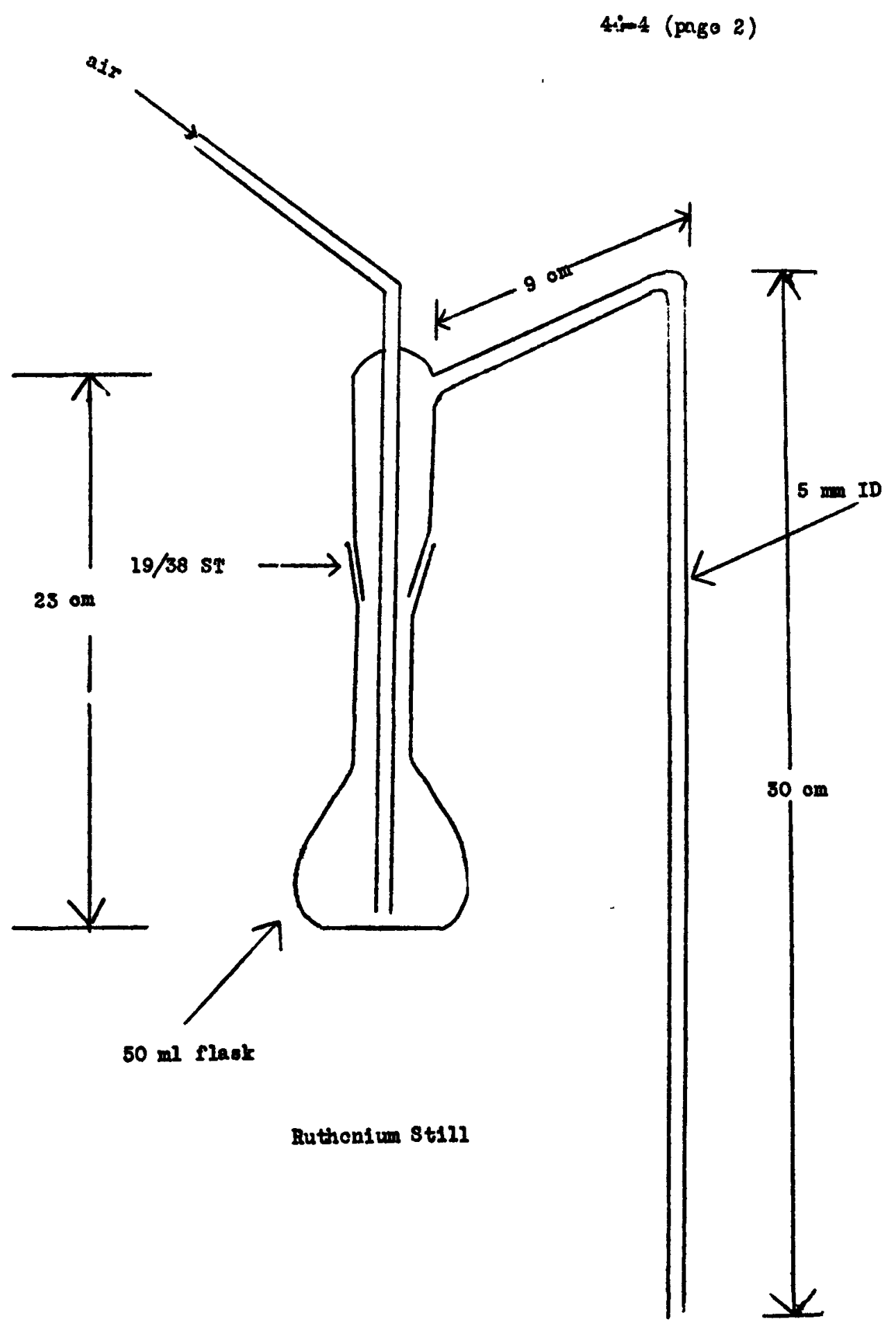

$8 / 24 / 49$

P-19-267

123 
CHEYTCAL SEPARATIONS

Blomont cparatod: Phodium

Targot matorial, Oranium motal (N I gm)

Typo of bbdt: 888 Lor alphas
Proooduro by: Tholfo

Imo for sop'n: 1 1/2 dayo whon coparatod with Pt and Ir.

Bquipmont roquirsd: Spoolal diatilling Mask, ocntrifugo, sop numols, Lus torold tubos, standard.

Y101d: 10\%

Dogroo of purifiontion: $10^{4}$ from fission produts (Hono from Ir)

Proooduro:

(1) Cut out tho contrnl portion of tho targot and bo11 with oono HCl to diesolve it and to oxpol Go.

(2) Add 5 mf $\mathrm{I}^{-}$and $\mathrm{IO}_{3}{ }^{-}$and boll the colution again to uxpol 10 dino.

(3) Add 20 ms 0s, Ir, Pt, and Au oarriers plus 20 ms Ba, Ru, Bh, and Pd oarriors. Withdraw a $20 \%$ allquot for dotormimtions of Bn, Han and $2 h$.

(4) To tho $20 \%$ aliquot add $\mathrm{HxO}_{\mathrm{g}}, 5 \mathrm{mg} \mathrm{mou}$ oarricr and $5 \mathrm{mg} \mathrm{I}^{-}$and $\mathrm{IO}_{3}{ }^{-}$. $B$ oll tho volution to oxpel $\mathrm{O}_{8}$ and I. (CAUTIOts $080_{4}$ vory polsonous.)

(5) Plaoe tho solution in a soolal all-glase distilling flask lilo that usod for the oantim distillntion. Add $0.6 \mathrm{maBiO}, 1$ ml cono $\mathrm{H}_{3} \mathrm{PO}_{4}$, and $20 \mathrm{ml} 70 \% \mathrm{HClO}_{4}$. Boll in an air stroam ilithout bumpinf cind distill ovor mo, Into $12 \mathrm{ml} 6 \mathrm{~g}$ MaOf in an 100 bath. Distili until $1-2 \mathrm{ml}$ of $\mathrm{BClO}_{4}^{4}$ havo distillod (2-3 min aftor fuming begino.) Soo (44-2).

(6) Tho residuc from this $\mathrm{Bu}$ distilintion is funod otrongly with tho $\mathrm{BCIO}_{4}$.

(7) Cool tho solution, diluto to $4 \mathrm{I}$ and add $20 \mathrm{ml}$ pyridino.

(8) Boll tho solution for 1 ivo minutos, placo in a soparatory furnol, and add 19 II liaCR to soparato tho froo-basc pyridino layor (tho high oon of knof is weroly to kocp tho volue low.)

(9) Theh the dark blue pyridine layer throo timos with oqual wolumes of diluto ECl. soporating tho layors oaoh tim with $6 \mathrm{I}$ BaCA.

(10) Add a fon drope of 6 I Hall to tho pyridino layor and ovaporato tho pyridino off.

(11) Pass $\mathrm{H}_{\mathrm{g}} \mathrm{s}$ into tho bolling allelino solution for sovoral wimtos, whilo tho solution is aoldiflod dropulso with BCL. Sulfidcs of Rh and Ir ppt. 
(12) Dissolve the ppt in a littlo aqua rogia. Add $6 \mathrm{mg}$ of Au, Pt, and Pa carriors.

(13) Neke soln 4 II in HCl and oxtraot twico ws th oqunl volumos of butyl acotate to deoontaminate from Ho and Au.

(14) Diluto tho solution to about $0.5 \mathrm{~N}$ in $\mathrm{H}^{+}$, add $5 \mathrm{ml}$ dimothyl-glyaximo solution ( $1 \%$ in cleohol) and filter off the Pd ppt.

(15) Fume the romining solutionw sth $\mathrm{H}_{2} \mathrm{SO}_{4}$, diluto, noutralizo to the brom orcsol purplc ond point, and $\mathrm{Cdd}^{4} \mathrm{BrO}_{3}$ to ppt tho hydrated oxides of $\mathrm{Rh}$ and Ir, loaving Pt in solution.

(16) Dissolvo the oxides in cono HCl and diluto to known volumo.

(17) An aliquot of proper sizo to $g$ tro about $5000 \mathrm{o} / \mathrm{m}$ is wi thdrawn and a known amount of Rh carrior is addod to it.

(18) Fumo with $\mathrm{H}_{2} \mathrm{SO}_{4}$, dilute tronty to ono, boil and ppt Rh motal by adding $\mathrm{TiCl}_{3}$ d'opwiso until a rory slight cxuoss is prosent.

(19) Plato this Rh motnl and oount.

Remarks :

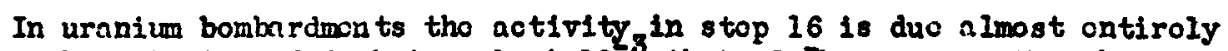
to $\mathrm{Rh}$, the aotivity of Ir belng sbout $10^{-3}$ that of $\mathrm{Rh}$-.. cron though no separation has bocn mado from Ir. In somo othor bomberding arrangemont whore the aotivitics of Ir sis $\mathrm{Bh}$ aro moro closoly oqual. Ir oould be soparated from the $R h$ by a procsdurc similar to tho last part of (77-3).

$R_{1}$, Ir and Pt should bo somrntod from ono bombardmont lonving $0 s$, Ru, and Pd for a socond bombardmont unlose sovoral pooplo aro cooporating on the proocdure.

For other plstinum wotal - fission product separations ssos

Pla tinum: $78-3$

Osmirm: 76-1

Ruthonium 44-2

Palladium 46-5

Iridi um 77-3

$8 / 16 / 49$ 
$46-1$

\section{CHEMCAL SEPARATIONS}

Elomont separatod: Pulladium

Prnooduro by: Gocolormann

Iargot material: of 1 i Bi metal

Timo for sop'n: Un 2 hrs.

Typo of bbdt: 184" a11 partiolcs

Equipmont roquirod, contrifugo, tubos, $110^{\circ}$ ovon

\section{Ylold: U $60 \%$}

Dogroo of purifloation: Dooontamination faotor $>10^{4}$ from flssion and spallation products.

Advantages: Falr yiold of pure Pd

Procodurc:

1. To aliquot of $\mathrm{HHO}_{\mathrm{g}}$ soln of targot add $10 \mathrm{mg} \mathrm{Pd}^{+2}$, mako up to $20 \mathrm{ml}$ $0.5 \mathrm{~N}$ HCl, add $5 \mathrm{ml}$ dimethyl-elyoxime colution ( $1 \%$ in alcohol). Tlash with diluto IICl.

2. Dissolvo proolpitgte in $1 \mathrm{ml}$ conocntratod $\mathrm{HHO}_{3}$, diluto with $10 \mathrm{ml}$ $\mathrm{H}_{2} \mathrm{O}$, add 5 ing $\mathrm{FO}^{+}$and mako basio with $\mathrm{iH}_{3}$.

3. Add $10 \mathrm{mg}$ As to supornatant and onough $I^{-}$to preoipitato all tho Ag. Ropoat AgI soavonging.

4. Make supornatant $0.5 \mathrm{I}$ in BCl and contrifugo out any AgCl. Idd $5 \mathrm{ml}$ dimothylglyoximo. Thash.

5. Ropeat purifioation oyole if nooded for highor purity.

6. Piltor last $\mathrm{Pd}$ dimothylglyoximo, wash with $\mathrm{H}_{2} \mathrm{O}$ and $\mathrm{C}_{2} \mathrm{H}_{5} \mathrm{OH}$, dry $10 \mathrm{~min}$. at $110^{\circ} \mathrm{C}$. Wolgh as $\mathrm{Pd}$ dimothylglyoximo (20.70 mg por 10 mf Pd).

Romarks: Zr and $A g$ aro the principlo contaminants of tho dimothyl-glyoxime ppt.

$7 / 29 / 49$

P-16-105 
CHEMTCAL SIPARATIOIS

Elcmont separatod: Palladium

Targot material: 4 g. 0 motal

Typo of bbdt: 184" a.11 high onorgy xartiolos
Procodure by: Folger 2 Hloks

Timo sor sop'n: $2 \mathrm{hr}$.

Equipmont requirod: contrifuga, oonos, vao. filter

Yiold: $\sim 60 \%$

Dogroo of purifioation: $\sim 10^{4}$ from all F.P. aotivitios.

Advantagos: cood yiold puro Pd.

Prooeduro:

(1) Add $10 \mathrm{mg} \mathrm{Fd}^{+2}$ and $10 \mathrm{mb} \mathrm{M1}$, mako $0.4 \mathrm{I}$ in $\mathrm{BrO}$, or $\mathrm{BCl}$, add 3-5 ml dimothyl-glyoximo solution ( $1 \%$ in cloohol). Thsh with diluto ECl or $\mathrm{BrO}_{3}(0.2$ II )

(2) Dissolvo prooipitate in 1 ml oonoontratod $\mathrm{mgO}_{3}$, dilute with $5 \mathrm{ml}$ $\mathrm{H}_{2} \mathrm{O}$, add $2 \mathrm{mg} \mathrm{Fo}+3$ and mako basto $\mathrm{wi}$ th $\mathrm{NH}_{3}$. Contrifugo and ropont If (OH) 3 soavongo.

(8) Add $10 \mathrm{mg} \mathrm{Ag}_{\mathrm{g}}$ to supornatant and onough $\mathrm{I}^{-}$to proolpitato all tho Ag. Contrifugo and ropoat $\Lambda_{g I}$ scavonging.

(4) supernatant $0.4 \mathrm{I}$ in $\mathrm{HCl}$ and oontrifugo out any $\Lambda_{g} \mathrm{Cl}$. Add 3-5 ml dimothylglyaximc. Wash.

(5) Ropont purifloction oyolo (stops $2,3,4$ ) if noodod for highor purity.

(6) Filtor last $\mathrm{Pd}$ dimothylglyoximo, wash with $\mathrm{H}_{2} \mathrm{O}$ and $\mathrm{C}_{2} \mathrm{H}_{5} \mathrm{OH}$, dry 10 min. at $110^{\circ} \mathrm{C}$. Hoigh as Pd dimothylglyoxim (20.78 mo por 10 mb $\mathrm{Pd}$ ).

Romarks :

Pd-d-m-g is quito bulky and may not oontrifugo. In suoh ocso, filtor with suotion. The ppt may bo disaolrod by adding oono moro $_{3}$ and catohing tho solution which runs through tho filtor.

$8 / 16 / 49$

P-18-181 


\section{CHEMICAL SEPARATIOMS}

Eloment soparatod: Palladium

Prooedure by: Licdner

Targot matorial: Sb ( $\sim .5$ metal)

Time for sep'n: $\mathrm{l}$ hr.

Type of bbat: $184 " \mathrm{D}_{2} \&$ a

Equipment required; Lusteroid tubes, oentrifuge, cones.

Y1eld: Groater than 50\%

Degree of purifloation: Faotor of at least 100

Prooedure:

(1) To discolve the Sb motal, add 15 drops of $27 \mathrm{IIF}$ to it in a lus torold tube in a hot wator bath. Add oono biro dropriso until dissolved ( 10 min.) Dilute to $\sim 20 \mathrm{ml}$.

(2) To the $\mathrm{SbF}$ - oolution add 20 meach of $\mathrm{TO}, \mathrm{Sg}, \mathrm{In}, \mathrm{Cd}, \mathrm{A}_{G}$, Pd, no. $16{ }^{4}$ \& carriers as solublo sal to. Add 2 drope oono. BCl. Contr2.. $r 8$ the $\mathrm{YP}_{3}$ and $A \mathrm{GCl}$ ppts.

(s) To half of the supn add $5 \mathrm{ml}$ of $1 \%$ dimothyl glyoximo in aloohol. Contrifugo.

(4) Fash tho Pd "DY" ppt with mator and dissolvo in aqua rogie. Braponte to drynoss. Ldd $10 \mathrm{ml} 2 \mathrm{IBCl}$. Add $1 \mathrm{~ms} \mathrm{Sb}, \mathrm{Sn}$, In. and Cd holdbeole ourriers and $5 \mathrm{ml} 1 \%$ "DIG" roagent in aloohol.

(5) Bopost (4) trico (do throo times altogether).

(6) Wash the ppt with water and then alochol.

(7) Plato the Pd "Dlor" ppt.

\section{$8 / 18 / 48$}




\section{CHEHICAL SEPARATIONS}

Element separated: Palladium

Target matorial: Thorium motal (.1-1 gm)

Typo of bbdt: $60^{\prime \prime} a^{\prime} s$

Yield: $\sim 80 \%$

Dogreo of purifioation: $N 10^{6}$ except from $\mathrm{Ag}^{+}$

Prooodure: The Th motal is dissolved in cono. $\mathrm{HCl}+$ a fow drops $2 \mathrm{M}$ solution $\left(\mathrm{HH}_{4}\right)_{2} \mathrm{SiF}_{6}$ to olear up black residuo. The $\mathrm{BCl}$ is diluted to $2 \mathrm{~N}$ and $\operatorname{an}^{2}$ alsquot takon.

(1) To sample add $20 \mathrm{mg} \mathrm{Pd}{ }^{++}$. If sample in $\mathrm{HCl}$, must add $\mathrm{FHO}_{3}$ to
oxidize Pd.

(2) Dissolvoppt in $1 \mathrm{ml}$ cono Bro, cool, dil with $10 \mathrm{ml} \mathrm{H} 2$, fdd $5 \mathrm{mg} \mathrm{Fe}^{+3}$. mako besio with exdoss NH OB. $\Lambda$ dd $10 \mathrm{mg} \mathrm{Ag}_{\mathrm{g}}^{+}$and enough $I^{-}$to ppt Ag. Contrifuge and roport soaronging.

(3) lake $0.4 \mathrm{~N}$ in $\mathrm{BCl}$ and contrifuge out any $\mathrm{AgCl}$. To supernats add 3-5 dimothyl elyoxime, wash.

(4) Ropeat purifioation cycle in 2 \& 3 for further purity. (5) Wash dimothyl glyoximo ppt with $\mathrm{H}_{2} \mathrm{O}$ and BtOH. Dry 20 min at
$110^{\circ}$. Feigh.

Romarice: $\mathrm{Zr}$ and $\mathrm{AE}^{+}$are prinoipal contaminants.

$10 \mathrm{mg} \mathrm{Pd}=31.6 \mathrm{mg} \mathrm{PaC}_{8} \mathrm{~N}_{4} \mathrm{O}_{4} \mathrm{H}_{17}$

(I) The Pd is in Th as oolloidal motal. Is not oxidizod to $\mathrm{Pd}^{++}$by HCl and does not exchange with carrier.

This mothod has been dosoribed proviously (Phys. Rev. 7517 (1949)).

\section{$8 / 23 / 49$}




\section{Elomont soparatod: Palladium}

Parget material: Uranium (motal)

Type of bbdt: 388 Mfov a's

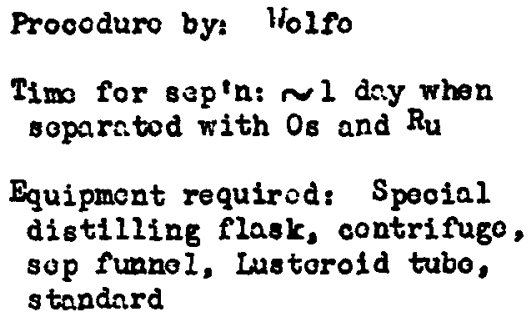
sop funnol, Lustorold tubo, standard

Yiold: $\sim 50 \%$

Dogroo of purification: $10^{3}$ from fission products

Procodurs:

(1) Cut out the contral portion of the target c.nd boll with oonoontrated BCl to dissolve it and to expol 00 .

(2) Aadd $5 \mathrm{mg} \mathrm{I}^{-}$and $\mathrm{IO}_{3}^{-}$and boll tho solution again to expol lodino.

(3) Add $20 \mathrm{mg}$ Os, Ir, Pt and Lu carriors plus $20 \mathrm{mg} \mathrm{hr}, \mathrm{Ru}$, In and Pd carricrs. Tithdrsw $=20 \%$ aliquot for lator doterminations of $\mathrm{Ba}$, $\mathrm{Ru}$, and $\mathrm{Rh}$.

(4) Placo tho romining solution in a sooial all-glass distilling flask having a thistilo tubo ontry and an $21 r$ cntry. Add conoontrated $\mathrm{BNO}_{3}$ through the thistlo tubo, and distill $0 \mathrm{sO}_{4}$ into $6 \mathrm{II}$ in in an loc bnth. (Saro for Os dotormination).

(5) Plooo the residue from the 0 s distillation in a beaker, add $10 \mathrm{ml}$ $70 \% \mathrm{HCLO}_{4}$ and boil tho solution to fumos of $\mathrm{HC}_{4}$ to 0 opol $\mathrm{Br}$.

(6) Dilute tho solution, add 5 mg moro Ru onrrior, and 5 mb moro $I^{-}$and $\mathrm{IO}_{3}$ and repeat the ruming.

(7) Sadd one $\mathrm{ml}$ dilute $\mathrm{BCl}$, diluto tho solution to $4 \mathrm{II}$ and oxtrsot trice with equal volumo butyl acotate to docontamimto from fle and from su.

(8) Dilute tho solution to $\sim 0.5 \mathrm{II}$ in $\mathrm{H}^{+}$, add $5 \mathrm{ml}$ dimothylglyoximo solution ( $1 \%$ in alcohol) and Filter off tho prlladium ppt.

(9) Dissolve ppt in $\mathrm{ZmO}_{3}$, diluto to $0.5 \mathrm{I}$ in $\mathrm{H}^{+}$, and roppt the $\mathrm{Pd}$ ding

(10) Dissolvo ppt in $\mathrm{BrO}_{3}$, add $2 \mathrm{mg} \mathrm{Lo}^{+++}$oarrior and ppt the hydroxido by adding $\mathrm{NH}_{4} \mathrm{OH}$. Dlssolvo ppt in $\mathrm{ErO}_{3}$ and ppt hydroxido tw100 moro.

(11) Add $10 \mathrm{mg} \mathrm{Ag}^{+}$to suph and enough $\mathrm{GL}^{-}$to $\mathrm{ppt}$ all tho $\mathrm{AE}_{\text {. Contrifugo }}$ and rapant igCl sosiongos twioc. Contrifugo off all heCl. 
(12) Diluto supp to known volum, transfor to a plasilo lustorold oontninor (to provont adsorption of se daughtor activity on glass walls) and timp in parafilin to provont oraporation.

(13) Allow the soln to stand for 12-16 hours until tho $3.2 \mathrm{hr} \mathrm{Ag}^{112}$ daughtor of 21 hour $\mathrm{Pd} 112$ hrs grown into oquilibrium. Thoroaftor at intervils of sbout a dny, known aliquots aro "milkod" $P f_{2}$ the $\mathrm{Ag}^{112}$ daughtor by AgCl pptas in ordor to detirmino dcony of $\mathrm{Pd}^{12}$.

Remarks: $06, R_{U}$ and $P d$ can bo taken from ono bombardmont loaring $\mathrm{Fh}$, Ir and Pt for a sooond bombardmont unloss seroral pooplo aro oooperatins on the procoduro.

For othor platinum motal - fission product soparations soo:

Platinum 78-3

Oamium 76-1

Iridium 77-8

Ruthoni um 14-2

Shodium 45-1

$8 / 17 / 49$

$P=18-246$ 
CHEYICAL SEPARATIONS

Elowont soparatod: Silvor

Targot matorial: 4 E. 0 metal foil

Typo of bbdt: $184^{\prime \prime}$ all high onerey partiolos
Prooodure by: Folger \& Hioks Timo for sop'n: ne hr.

Bquipmont roquirod: Contrifuge, cones, microburncr, $110^{\circ}$ oven

IHold: UA 80\%

Dogrce of purification: $\$ 10^{3}$ from all F. P. notivitios

Advantages: Relatively simple procoduro giving good separation in high yicld.

Proocduro:

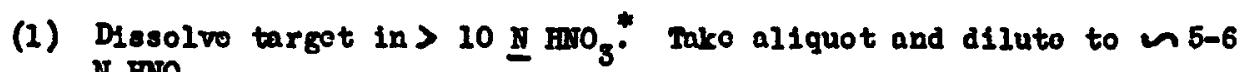
II $\mathrm{HNO}_{3}$

(2) Add aorosol and prooipitato $\triangle \mathrm{GCl}$ with $1 \mathrm{ml} 0.5 \mathrm{H} \mathrm{HCl}$." Fash turloo with $10 \mathrm{ml} 1 \mathrm{II} \mathrm{BNO}_{3}$ containing 1 drop 2 N

(5) Dissolvo $\mathrm{AgCl}$ in $2 \mathrm{ml} 6 \mathrm{~N} \mathrm{NB}_{\mathrm{A}} \mathrm{OH}$, dilute to $10 \mathrm{ml}$, and add $2 \mathrm{mg} \mathrm{Fo}^{+3}$ Contrifugo $\mathrm{Fo}(\mathrm{OH})_{3}$ and repoát sosvonge (may bo dono in same tube.)

(4) Saturate supernatant with $\mathrm{H}_{2} \mathrm{~S}$ in the cold, wash $\mathrm{Ag}_{2} \mathrm{~S}$.

(5) Dissolvo $\mathrm{Ag}_{\mathrm{g}} \mathrm{S}$ in $2 \mathrm{ml}$ ooncontratod $\mathrm{HNO}_{3}$,boll, diluto to approx. $4 \mathrm{I}(6 \mathrm{ml})$ and prooipitato $\mathrm{AgCl}$ with $13 \mathrm{ml} 0.5 \mathrm{I} \mathrm{BCl}$. Fash twioo with $\mathrm{BrO}_{3}$ oontaining 1 drop $2 \mathrm{I}$ BCl.

(6) Bopoat (3).

(7) Ropoat (4).

(8) Dissolvo $\mathrm{Ag}_{2} \mathrm{~S}$ in $1 \mathrm{ml}$ ooncontratod $\mathrm{WNO}_{3}$, boil to destroy or romovo all $\mathrm{H}_{2} \mathrm{~S}$ diluto to $6 \mathrm{ml}$, add $1 \mathrm{mg} \mathrm{Po}$, and make basio with $\mathrm{IH}_{3}$.

(9) Add aorosol, mako $2 \mathrm{X}$ in $\mathrm{HNO}_{3}$, add 2 drons $6 \mathrm{~N} \mathrm{HCl}$ and boll to coagulate. Filtor, wash throo times with $5 \mathrm{~m} 0.5 \mathrm{~N}$ Hro $\mathrm{m}$ throo timos with $6 \mathrm{ml} \mathrm{C}_{2} \mathrm{H}_{5} \mathrm{OB}$, dry $10 \mathrm{~min}$. at $110^{\circ} \mathrm{C}$. $701 \mathrm{gh}$ as $\mathrm{AgCl}$ (13.28 ng por $10 \mathrm{mg} \Lambda_{E}$ ).

Bomarke:

* Ag carricr should bo addod to tho containor in which targot is dissolvod in ordor to prevent $108 s$ of traoo if by absorption in the glass. $\Lambda n$ amount of oarrior should bo addod so that the aliquot w1ll contain 10-20 mb.

* Boiling tho solution ovor a mloroburner with stirring (boing caroful to aroid loss by bumping oror) causos rapid and oomploto coagulation of $\mathrm{AgCl}$.

In stop 2 addition of a fow drops $\mathrm{Br}$ plus 2 drops $50 \% \mathrm{~K}_{2} \mathrm{CO}_{3}$ will provido additional dooontamination from these oloments. 
CHELICAL SMPIRATIONS

Elcment soparatod: Sllver.

Proocduro by: Goockormann

Targot matorialien 1 G Bi motal

Timo for sopin: $\mathrm{h}^{2} \mathrm{hrs}$.

Typo of bbdt: 184" all particlos

Equipment requirod: Contrifuco, tubos, $100,110^{\circ}$ ovon

\section{Yicld: $\mathbf{0} 80 \%$}

Degrco of puriflcation: Docontamination factor $>10^{4}$ from fission and spallation products

Advantages: Good yiold of pure $A_{G}$

Proooduro:

(1) To a.liquot of $\mathrm{HNO}_{3} 801 \mathrm{n}$ of target add $10 \mathrm{mg}$ A6, acrosol, diluto to $20 \mathrm{ml}$, and preôipitato $A_{\mathrm{ECl}}$ with $1 \mathrm{ml} 6 \mathrm{~N} \mathrm{HCl}$. Wash with $10 \mathrm{ml}$ H.

(2) Dissolve $\mathrm{AgCl}_{\mathrm{G}}$ in $2 \mathrm{nl} 6 \mathrm{~N} \mathrm{NH}_{4} \mathrm{OH}$, dilute to $10 \mathrm{ml}$, and add $6 \mathrm{mg} \mathrm{Fo}^{+3}$.

(3) Saturato supornatant wi th $\mathrm{H}_{2} \mathrm{~S}$ in the cold, wash $\alpha_{E_{2}} \mathrm{~s}$.

(1) Dissolvo $\mathrm{Ag}_{2} \mathrm{~S}$ in $1 \mathrm{ml}$ conocntratod Hro ${ }_{3}$, diluto to $20 \mathrm{ml}$, and proolpitate ${ }_{\mathrm{AgCl}}$ with $1 \mathrm{ml} 6 \mathrm{II}$ HCl. Falh with $\mathrm{H}_{2} \mathrm{O}$.

(5) Pepoat (2).

(6) Ropeat (3).

(7) Disgolvo $\mathrm{Ag}_{2} \mathrm{~S}$ in $\mathrm{Iml}$ conoontratod $\mathrm{HNO}_{3}$, diluto to $10 \mathrm{ml}$, add $5 \mathrm{mg}$ $\mathrm{Fe}+\mathrm{s}$, and malo basio $\mathrm{w} 1$ th $\mathrm{MH}_{3}$.

(8) Add 5 drons 6II BCl to supornatant, add aorosol, mako 11 in in $\mathrm{BrO}_{3}$, heat, filter, Fash threo times with $5 \mathrm{ml} \mathrm{H}_{2} \mathrm{O}$, thrco tim s with $5 \mathrm{ml} \mathrm{C}_{2} \mathrm{H}_{5} \mathrm{OH}$, dry $10 \mathrm{~min}$. at $110^{\circ} \mathrm{C}$. Weigh ${ }^{2} \mathrm{se}$ AgCl (15.28 mg por $10 \mathrm{mg} 28 \%$.

nomarkof mildison suggested an clootrolysis proocduro involving plating

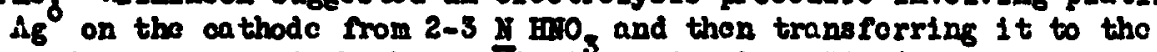
amdo in a granidc bath .. this 18 good unloss Pt, du, Ir, or Os aro presont. 


\section{CERMICAL SEPARITIONS}

Element separated: Silver

Parget material: Cd (separated isotopes)

Type of bbdt: Deuterons and protons - $60^{\prime \prime}$
Procedure by: R. C. Lilly

Time for sep'n: 30-40 minutes

Equipment required: beakers, funne ls, Hirsoh funnel

Yield: $\sim 90 \%$

Degree of purifioation: Eood - at least faotor of 100 from other aotivities present.

Advantages: Simplioity

Procedure:

(1) Dissolve the Cd target, weighing 10-15 mg, in a fer milliliters of oone. HNo in a 3 mall beaker. Then all of the material has dissolved, evapornte to dryness to drive off excess $\mathrm{HrO}_{3}$.

(2) Add $3-4 \mathrm{mg}$ In and 3-4 $\mathrm{mg}$. Ag as the nitrate sol'ns and dilute to $\sim 10 \mathrm{ml}$ with $\mathrm{B}_{2} \mathrm{O}$.

(3) Add I I KCl dropwise until the 48 is completely ppt 'd as ApCl. Coegulato the ppt by hoating and filter through a small "42 Fhatman fliter paper in a short-stemmed glass funnel. (The filtrito oontains the Cd and In fraotions and is worked up separately as described in the prooedures for Cd and In from Cd targets, Nos. 48-3 and $49-1$.

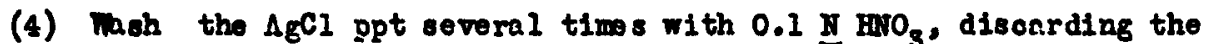
washes. Dissolve ppt through paper with $6 \mathrm{II} \mathrm{MH}_{4} \mathrm{OH}$, collecting the soln in another small beaker.

(5) To scavange for In, add 2-3 me pe as $\sim 5 \mathrm{ml}$ of Focl, soln, stirring well during the addition. Coagulate the ppt by heating, fliter, and disoard it.

(6) Ro-aoidify the filtrate with Hro, and add a fow drops of 1 II HCI to make sure that the $A_{G} C l$ is completely ppt'd. Coagulate the ppt by heating and filter through a 142 matman paper diso held in a Gooch crucible or Hirsch funnel.

(7) Suok the sample as dry as possible and then pour $1-2 \mathrm{ml}$ acetone through the paper to remove the residual $\mathrm{H}_{2} \mathrm{O}$. Whon the paper diso is dry, mount under tape.

Remarks: Soe Soott (Std. Woth. Chem. Anal.) fol oomplete information on the ppt'n of AfCl.

$8 / 17 / 49$ 


\section{CHEMICAL SEPARATIONS}

Element separated: Silver

Prooedure by: Lindner

Target material: Sb ( $\sim 5$ metal)

Time for sep'n: $\sim 1 \mathrm{hr}$.

Type of bbdt: $184 " D_{2} \&$ a

Equipmont requirod: Lusteroid tubes, contrifuge, oones

Yield: Equal or greater than $50 \%$

Degree of purfifiotion: $\Delta t$ least factor of 100.

Procedure:

(1) To dissolve the $\mathrm{Sb}$ metal, add 15 drops of 27 II HF to it in a lusteroid tube in a hot water bath. Add cono HWO $_{3}$ dropwise until dissolrod ( $10 \mathrm{~min})$. Dilute to $\sim 20 \mathrm{ml}$.

(2) To the $\mathrm{SbF}_{4}^{-}$solution add $20 \mathrm{mg}$ each of $\mathrm{Te}, \mathrm{Sn}$, In, Cd, Ac, $\mathrm{Pd}, \mathrm{Ru}, 1 \mathrm{~S}^{4} \mathrm{Y}$ carriers as soluble salts. Add 2 dropo oono. BCl. Centrifige the $\mathrm{WF}_{3}$ and AgCl ppts.

(3) Tash the ppt with 1 II EF.

(4) Dissolve out the $\mathrm{Af}^{+}$from the ppt by adding $1 \mathrm{ml}$ oono. $\mathrm{NH}_{4} \mathrm{OH}$. Centrifuge.

(5) Dilute the supn to $5 \mathrm{ml}$ and add $2 \mathrm{mg} \mathrm{Fe}^{+++}$carrier. Centrifuge and discard the ppt of $\mathrm{Fe}(\mathrm{OH})_{3}$.

(6) Add 1 each $\mathrm{Sb}, \mathrm{Sn}$, In and Cd oarriers. Add $\mathrm{l} \mathrm{ml}$ cono. HirO 5 and 1 drop conc. HCl. Contrifuge out the AGCl ppt.

(7) Add $1 \mathrm{ml}$ cone. $\mathrm{NH}_{4} \mathrm{OH}$ to the ppt and ropeat (6).

(8) Add $2 \mathrm{ml} 6 \mathrm{~N} \mathrm{NaOH}$ to the $\mathrm{AgCl}_{\mathrm{g}}$ ppt. Digest 10 minutes in hot water bath. - Dilute to $10 \mathrm{ml}$ \& oentrifuge.

(9) Thosh the $\mathrm{AB}_{2} \mathrm{O}$ ppt with water and then dissolve in 1 drop cono. BnrO $_{3}$.

(10) This solution can bo plated or if o hemical yield is to be determinod the $A_{G}$ should be weighed as $\mathrm{AgCl}$.

$8 / 18 / 49$

$P=18-224$ 
Blemont soparated: silver

Targot matorial: Thorium motal (.1-1 gm,

Type of bbdt: $60^{\prime \prime} \mathrm{a}^{\prime} \mathrm{s}$

Yiold: $\sim 85 \%$

Dogrco of purification: $N 10^{6}$ exoopt from Pd
Procodure bys Newton

Time for sep'n: $1 \mathrm{hr}$

Equipmont required: Standard, tank $\mathrm{H}_{2} \mathrm{~S}$

Procodure: Th metal dissolved in cono BCl + a few drops 2 M solution $\left(\mathrm{NH}_{4}\right)_{2} \mathrm{SiF}_{6}$ to clear up black residuo. The HCl is diluted to $2 \mathrm{II}$ and an dilquot taken.

(1) Add $20 \mathrm{mg} \mathrm{Ag}^{+}$to samplo after diluting to $0.3 \mathrm{~N} \mathrm{HCl}$. Digest a few min. Contrifuge $A_{6} C l$ ppt of and wash with $10 \mathrm{ml} \mathrm{H}_{2} \mathrm{O}$.

(2) Disgolve $\Lambda_{\mathrm{gCl}}$ in $2 \mathrm{ml} 6 \mathrm{NH}$ OH. Dilute to $10 \mathrm{ml}$ and add $5 \mathrm{mg}$ $\mathrm{Fe}^{+3}$. Contrifuge off $\mathrm{Pe}(\mathrm{OH})_{3}^{4}$. Idd more Fo and rocentrifugo. Saturato supermate with $\mathrm{H}_{2} \mathrm{~S}$. Trocipitato $\mathrm{Ag}_{2} \mathrm{~S}$. Mash $\mathrm{Ag}_{2} \mathrm{~S}$.

(3) Dissolvo ppt in $1 \mathrm{ml}$ cono $\mathrm{FHO}_{8}$. Dil to $10 \mathrm{ml}_{\mathrm{i}}$ Neutralizo with $6 \mathrm{I}_{4} \mathrm{OF}$ ind add $1-2 \mathrm{ml}$ exooss. Add $5 \mathrm{mg} \mathrm{Pe}$. Discard ppt.

(4) Ropeat $\Lambda_{\varepsilon_{2}} \mathrm{~s}$ ana $\mathrm{Fo}(\mathrm{OH})_{3}$ pptns.

(5) To last $\Delta_{\mathrm{g}}\left(\mathrm{KH}_{3}\right)_{4}^{+} 801$, add 5 drops $6 \mathrm{H} \mathrm{HCl,} \mathrm{aerosol} \mathrm{and} 2 \mathrm{ml}$ $6 \mathrm{II} \mathrm{EO}_{3}$. Hodt and filter. Fhah threo timos $5 \mathrm{ml} \mathrm{H}_{2} \mathrm{O}$, threo

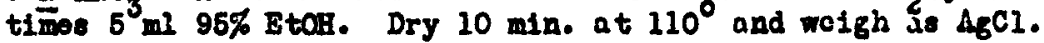

Remarks:

$10 \mathrm{mg} A \mathrm{~g}^{+}=13.3 \mathrm{mg} \mathrm{AgCl}$ (H.T. 143.34)

This method has been desoribed previously (Phys. Rov. 7517 (1949)).

$\mathrm{Ac}^{+}$is adsorbod vory rapidly by glass in oarrior freo solution. Dissolvo and troat in quarts or lustoroid till oarrior added, othorwiso most of activo $\lambda_{E}^{+}$way be loat.

$8 / 23 / 49$ 
Elomont soparatod: Cadmium

Target material: in 4 g. U motal foll

Typo of bbdt: 181" a11 particlos

Yleld: $70 \%$

Dogroo of purification: $>10^{3}$ from all F. P. activitios.

Procodure:

(1) Add $10 \mathrm{mg} C \mathrm{Cd}$ and $\mathrm{Cu}$ as indicator and make basio with $\mathrm{MH}_{3}$, contrifugo. Wash ppt with $\mathrm{MH}_{4}$ OH and combine washings.

(2) Saturato supornatant with $\mathrm{H}_{2} \mathrm{~S}$ and contrifuge, wash.

(5) Dissolve proolpitato in minimum quantity oonc. HCl and o vaporato. Dissolvc in $10 \mathrm{ml} \mathrm{H}, 0$ add 5 , $\mathrm{Fe}^{+++}, \mathrm{La}^{+++}$, and In ${ }^{+++}$add $\mathrm{KR}_{3}$ and contrifuge. Ada more $F e^{+74}$ and contrifuge on top of first.

(4) Pass $\mathrm{B}_{2} \mathrm{~s}$ into supernatant and contrifugo.

(5) Dissolvo ppt in $3 \mathrm{ml}$ oonc. $\mathrm{HrO}_{3}$ and dilute to $8 \mathrm{ml}$. Add $\mathrm{Ag}^{+}$and $\mathrm{Cl}^{-}$ and contrifuge.

(6) Noutralizo supo rnatant with $\mathrm{MH}_{3}$, add onough solid KCI to complex $\mathrm{Cu}$ and pass in $\mathrm{H}_{2} \mathrm{~S}$.

(7) Dissolve Cas in $2 \mathrm{ml} \mathrm{HCl}$, dilute to $6 \mathrm{ml}$, add $10 \mathrm{~ms} \mathrm{Pd}^{+2}$, hoct, and saturato with $\mathrm{H}_{2} \mathrm{~S}$.

(8) Add $\mathrm{Sb}^{+3}$ to supornatant and scavonge with $\mathrm{Sb}_{2} \mathrm{~S}_{3}$.

(9) To supormatant add cxocss $\mathrm{NH}_{4}$ ad and saturato with $\mathrm{H}_{2} \mathrm{~S}$.

(10) Dissolvo Cas in a fow drops of HCl, craporate to drynoss. Dissolve in $9 \mathrm{ml}$ of a solution containing $3 \mathrm{ml} 6 \mathrm{~N}$ Hio and $6 \mathrm{ml}$ of $6 \mathrm{~N}$ iH $\mathrm{A}_{\mathrm{O}}$. Boat, add $2 \mathrm{ml} 1.5 \mathrm{~N}\left(\mathrm{NH}_{4}\right)_{2} \mathrm{EPO}$, and di gost hot for $15 \mathrm{~min}$. Filtor, wash with $\mathrm{H}_{2} \mathrm{O}$, dry $10 \mathrm{~min}$. at $110^{\circ} \mathrm{C}$. Woigh as $\mathrm{CdNH}_{4} \mathrm{PO}_{4} \cdot \mathrm{H}_{2} \mathrm{O}$ (21.66 mg por $10 \mathrm{mg} \mathrm{CC}$ ). 
CHELICAI SEP:RATIONS

Slomont soparatod: Cadnium

Target matcrinl: in 1 g Bi motal

Typo of bbdt: $184^{\prime \prime}$ all particles

riold: 年 70\%
Proocduro by: Goockormann

Timo for scpin: $2 \mathrm{hrs}$.

Equipmont requircd: Contrifugc, tubes, $\mathrm{H}_{2} \mathrm{~S}$ tark,
$110^{\circ}$ ovon

Dogrce of purifloation: Decontanination faotor $>10^{4}$ from fission and spallation products.

idvantagos: Good yleld of pure Cd

Procoduro:

(1) To aliquot of $\mathrm{HNO}_{3}$ ooln of targot add $10 \mathrm{mg}$ Cd and mako basic with $\mathrm{NH}_{3}$, contrifuge out $\mathrm{Bi}(\mathrm{OHI})_{3}$

(2) $\Lambda$ dd $10 \mathrm{ml}$ concontrated HCI to supcrnatant and ovnporato to dryncss. Tako up in $20 \mathrm{ml} 0.2 \mathrm{IHCl}$ and saturato with $\mathrm{H}_{2} \mathrm{~S}$. Wash CdS with $\mathrm{H}_{2} \mathrm{~S}$ wator.

(3) Dissolrg CdS in $1 \mathrm{ml} 6 \mathrm{~K} \mathrm{HCl,} \mathrm{boil} \mathrm{out} \mathrm{H}_{3} \mathrm{~S}$, diluto to $10 \mathrm{ml}$, add 5 ms $\mathrm{FO}^{+5}$ and $6 \mathrm{~N} \mathrm{NH}_{4} \mathrm{OH}$ drobmise unt1l $\mathrm{Fe}(\mathrm{OH})_{3}$ precipitation bogins. Rodissolvc 1-2 drops $\mathrm{HCl}$, hont, add 4-5 drons $6 \mathrm{~N}_{3} \mathrm{CH}_{3}$ coONH, contrifugo out basic ferric aootato prcelpitato.

(1) Add 10-15 drops 6N HCl to supernatant and precipitato Cds.

(5) Dissolve CaS in HCl and cxpol $\mathrm{H}_{2} \mathrm{~S}$, add scroral $\mathrm{g}$ In and precipitato with $\mathrm{NH}_{3}$.

(6) Ro-aoidify and prooipitatc cdS.

(7) Dissolvo CdS in $2 \mathrm{ml} 6 \mathrm{~N} \mathrm{HCl}$, diluto to $10 \mathrm{ml}$, add $10 \mathrm{mE} \mathrm{Pd}^{+2}$, hoat, and saturato with $\mathrm{H}_{2} \mathrm{~S}$.

(8) Add $5 \mathrm{mg} \mathrm{sb}^{+3}$ to supornatant and scavongo with $\mathrm{sb}_{2} \mathrm{~s}_{3}$.

(9) To supcrmatant add oxcoss $\mathrm{NH}_{4} \mathrm{OH}$ and saturate with $\mathrm{H}_{2} \mathrm{~S}$.

(10) Dissolvo CaS in a for drops of $\mathrm{HCl}$, oxpol $\mathrm{H}_{2} \mathrm{~S}$, diluto to $15 \mathrm{ml}$, add $2 \mathrm{ml} 3 \mathrm{M} \mathrm{HCl}$, boll, add $2 \mathrm{ml} 1 \mathrm{M}\left(\mathrm{NH}_{4}\right)_{2} \mathrm{HPO}_{4}$, and digost hot $15 \mathrm{~min}$. Iflter, wash w1 th $\mathrm{H}_{2} \mathrm{O}, \mathrm{dry} 10^{4} \mathrm{~min}$. Et $110^{\circ} \mathrm{C}$. Woigh as $\mathrm{CdNH}_{4} \mathrm{PO}_{1} \cdot \mathrm{H}_{2} \mathrm{O}$ (21.66 ms per $16 \mathrm{mg} \mathrm{Cd}$ ).

$7 / 29 / 49$

P-18-103 
CHATIC:L SEP:RITIOIS

Elomont soparatod: Cadmium

Targot matorial: Cò(scparatod isotopes)

Typo of bbat: Doutcrons and protons - 60"
Proooduro by: R. C. Lilly

Timo for sep'n: 2-3 hours

Equipmont roquirod: Boakors, funnols, Hirsch funncl, soparatory funnols, $\mathrm{pH}$ motor.

vjold: $\sim 90 \%$

Dogroo of purification: good - at lonst faotor 100 from othor aotivitios prosent.

Advatages: Good separation

Prooeduro:

(1) Dissolvo tho cd targot, waighing 10-15 mg, in a fow millilitors of conc $\mathrm{HNO}_{3}$ in a small boakcr. Then all of the matorial has dissolvod, Evaporato to drynoss to drivo off oxcoss $\mathrm{HNO}_{3}$.

(2) Add 3 - $4 \mathrm{mg}$ In and 3-4 mE Ag as tho nitrato sol'ns and diluto to $\sim 10 \mathrm{ml}$ with $\mathrm{H}_{2} \mathrm{O}$.

(3) Add $1 \mathrm{~N} \mathrm{HCl}$ droprise until tho ig is complotoly pptid as AfCl. Coaguiate tho ppt by heating and filtor through a small if 42 Whatman filtor paper in a short-stommo gla 88 funnol. The filtrato contains tho $\mathrm{Cd}$ and In fractions. (Tho $\mathrm{AgCl}$ ppt is rorkod up separatoly as desoribod in tho proooduro for ing from cd targets, No. $47-3)$.

(4) Wko the filtrato ammoniacal and add anothor 3-4 me ing as tho nitrato sol'n. ioidify $\mathrm{WIth}_{\mathrm{H}} \mathrm{HNO}_{3}$ and add a fow drops of $1 \mathrm{~N}$ $\mathrm{HCl}$ to insure comploto pptin of $\mathrm{SgCl}$. Congulato tho ppt by hoating, filtor on \#42 papor, and discard.

(5) Idjust the $\mathrm{pH}$ of tho filtrato to 3.5 with $\mathrm{NH}_{4} \mathrm{OH}$ and transfor to a $50 \mathrm{ml}$ separatory funnel.

(6) Extraot the In by shaking with throo portions of $0.02 \mathrm{M}$ 8-hydroxyquinoline in $\mathrm{CE}_{3} \mathrm{Cl}$, drawing tho organio layers off into a second soparatory funnil aftor oach pass. Disoard tho fow drops of mixed sol'n which romain in the sopoock aftor soparation of laycrs. (Tho In is contained in this organic layor and is worked up separatoly as doscribod in tho procodure for In from Cd targets, No. 49-1).

(7) Add 3-4 mg In as the nitrato sol'n to tho Ho layer romaining in the first funncl. Repeat the oxtractions as outlind in (6) above, but this timo discard the throo organio laycrs oontaining the scavenger In. 
(8) Draw the $\mathrm{H}_{2} \mathrm{O}$ laynr into a boaker, boll off rcsidual $\mathrm{CH}_{3} \mathrm{Cl}$, and add $28 \mathrm{BH}$ OH to ppt $\mathrm{Cd}$ as the 8-hydroxyquinolate. Filter through a \#2 thatman paper disc hold in a Coooh orvoiblo or Hirsch funnol. Suok the sample on the papor as dry as possible and then oomplote tho drying under a hoat lomp boforc mounting under tapo.

Romarike :

Sce Soott (Std. Ifth. Chen. Inal.) for comple to information on the ppt'n of dgCl.

Sco Sandell (Colorirotric Detormination of Traces of liotnis) for further information on tho cxtraction of In with 8-hydroxyquinolino.

$8 / 18 / 49$

P-18-235 


\section{GHEICLL SEPIRATIONS}

Mlemont soparated: Cadmiun

Target matcrial: $\mathrm{Sb}(\sim .5 \mathrm{gm}$ motal)

Type of bbdt: $184^{n}$ a \& $\mathrm{D}_{2}$
Procedure by: Lindner

Time for sop'n: $N 2$ hours

Equipment requirod: Lus teroid tubes, oentrifugo, cones, tank $\mathrm{H}_{2} \mathrm{~S}, \mathrm{SO}_{2}$

Yield: $50 \%$ or greater

Dogrco of purification: lit least factor of 100.

Proooduro:

(1) To the targot add 15 drops $27 \mathrm{~N}$ HF in Iusterold tubo in hot water bath. Idd oono $\mathrm{BNO}_{3}$ dropwise until dissolvod (10 min.) Diluto to $\sim 20 \mathrm{ml}$. 20

(2) Add/mg oach To, Sn, In, Cd, AE, Pd, Ru, 4b, Y oarriors as solublo salts. Add 2 drops oono BCl. Contrifugo.

(3) Divide supp into two equal parts.

(4) Evaporate ono part to near-drynose. Cool, add $20 \mathrm{ml} 3$ II HCl.

(5) Boil the supn to expel $\mathrm{SO}_{2}$, add $5 \mathrm{ml} \mathrm{H}_{2} \mathrm{O}$.

(6) Satura to hot with $\mathrm{H}_{2} \mathrm{~S}$ until $\mathrm{Sb}_{2} \mathrm{~s}_{3}$ ppten oomploto.

(7) Evaporate the supa to noar dryness. Take up in $15 \mathrm{ml} I$ II NaOH.

(8) Wash tho Cd and In hydroxide with very diluto NaOH, dissolvo in HCl. Add 2 mg $\mathrm{Sn}^{+4}$ holdback.

(9) Repeat $\mathrm{KaOH}$ potn, dissolve and make to $15 \mathrm{ml}$ in $2 \mathrm{H} \mathrm{HCl}$.

(10) Add $5 \mathrm{mg} \mathrm{sb}{ }^{+++}, 2 \mathrm{mg} \mathrm{ToO}_{3}=$ and saturate with $\mathrm{H}_{2} \mathrm{~S}$.

(11) Boll supn to oxpel $\mathrm{H}_{2} \mathrm{~s}$. Add excoss $\mathrm{MH}_{4}$ OH. Contrifugo.

(12) To the supn containing the $\mathrm{Cd}\left(\mathrm{MH}_{3}\right)_{4}^{++}$complex add $2 \mathrm{mg} \mathrm{In}^{+++}$. Centrifugo off the $\operatorname{In}(\mathrm{OH})_{3}$ ppt.

(13) Saturato sup'n with $\mathrm{H}_{2} \mathrm{~s}$. Contrifugo cdS ppt.

(14) Dissolve CaS in BCl.

(15) Diluto an aliquot of solution to $15 \mathrm{ml}$. Add $11 \mathrm{ml} 3 \mathrm{M} \mathrm{IHH}_{4} \mathrm{Cl}_{1}, 1 \mathrm{ml}$ $1.5=\left(\mathrm{NH}_{4}\right)_{2} \mathrm{HPO}_{4}$ and wo Igh the $\mathrm{CdNH}_{4} \mathrm{PO}_{4} \cdot \mathrm{H}_{2} \mathrm{O} \mathrm{ppt}$ formod.

$8 / 18 / 49$ 


\section{CHEMICAL SEPARATIONS}

Element separated: Cadmium

Targot material: Thorium motal (.1-1 gm)

Type of bbdt: $60^{\prime \prime}$ a's $^{2}$
Procodure by: Nowton

Timo for sepin: 2 hrs.

Equipmont roquired:

Standerd, tank $\mathrm{H}_{2} \mathrm{~S}$

Yicld: $50 \%$

Degreo of purification: $\sim 10^{5}$ from fission products

Procodure: The metal dissolved in oone HCl + a ferr drops .2 M solution

$\left(\mathrm{NH}_{4}\right)_{2} \mathrm{SiF}_{6}$ to olear up blaok residue. The HCl is diluted to $2 \mathrm{~N}$ and an âliquot taken.

(1) Add $10 \mathrm{mg}$ cadmium carrier. Diluto to $0.2 \mathrm{~N} \mathrm{HCl,} \mathrm{pass} \mathrm{in} \mathrm{H}_{2} \mathrm{~s}$, ppt CdS. Whash with $\mathrm{H}_{2} \mathrm{~S}$ water.

(2) Dissolve CdS in $1 \mathrm{ml} 6$ N $\mathrm{HCl}$. Boil out Hes. Diluto to $10 \mathrm{ml}$. Add $5 \mathrm{mg} \mathrm{Fe}, 5 \mathrm{mg} \mathrm{Ia}^{+3}, 5 \mathrm{mg} \mathrm{In}^{+3}$ add $\mathrm{HH}_{\mathrm{f}}$ CH. Preolpitato $\mathrm{Fo}(\mathrm{OH})_{3}$. Centrifuge. Add more $\mathrm{Fe}^{+5}$ and scâvenge again, centrifuging dorrn on top of first.

(3) Pass $\mathrm{H}_{2} \mathrm{~S}$ into supermatc, ppt Cas.

(4) Dissolvo CdS in $1 \mathrm{ml} 6 \mathrm{~N} \mathrm{HC1,} \mathrm{bil,} \mathrm{diluto} \mathrm{to} 10 \mathrm{ml}$, hoat, add $\mathrm{Ag}^{+}$, ppt $\mathrm{AgCl}$, digest a fow miln., contrifuge.

(5) Add $\mathrm{NH}_{4} \mathrm{OH}$ until alkalino, pass in $\mathrm{H}_{2} \mathrm{~s}$, ppt CdS.

(6) Drssolvo $\mathrm{Cd}$ in $2 \mathrm{ml} 6 \mathrm{I} \mathrm{HCl}$. Dil to $10 \mathrm{ml}$. Add $10 \mathrm{mg} \mathrm{Pd}$ heat and saturate with $\mathrm{H}_{2} \mathrm{~S}$, ppt PdS. Ropeat sulfide sonvenging with 5 mb.

(7) To supo mate add $2 \mathrm{ml} 6 \mathrm{II} \mathrm{MH}_{4}$ OH saturate $\mathrm{H}_{2} \mathrm{~S}$. Ppt CdS.

(8) Dissolvo CAS in a fow dropo HC1. Boil to expol $\mathrm{H}_{2} \mathrm{~S}$. Dilute to $15 \mathrm{ml}$. Add $1.5 \mathrm{ml} 3 \mathrm{y} \mathrm{NH}_{4} \mathrm{Cl}$, boil, add $1.5 \mathrm{ml}^{2} \mathrm{l} .5 \mathrm{M}\left(\mathrm{NH}_{4}\right)_{2}$ $\mathrm{HPO}$ and digest hot 15 minuts. Filter. Fash with $\mathrm{H}_{2} \mathrm{O}$, dry 10 min. at $110^{\circ}$. Poigh as $\mathrm{Cd}\left(\mathrm{NH}_{4}\right) \mathrm{PO}_{4}+\mathrm{H}_{2} \mathrm{O}$.

Romarks :

$10 \mathrm{mg} \mathrm{Cd}=21.63 \mathrm{mg} \mathrm{CaNH} \mathrm{PO}_{4} \cdot \mathrm{H}_{2} \mathrm{O}$ (M.H. $=243.45$ )

Thls wo thod has been deseribed previously (Phys. Rev. 7517 (1949)).

\section{$8 / 28 / 49$}


Glement separatod: Indium

Target material: Cd (separated isotopes)

Type of bbdt: Deuterons and protons - 60"

rield: $\sim 90 \%$
Procedure by: R. C. LIIy

Timo for sep'n: $2-3$ hours

Equipment required: Beakers, funne 10, Hirsoh funnol, soparatory funnels, pal moter

Degree of purification: good - at least factor of 100 from other aotivitios present.

\section{Advantages: Good separation}

Procedure:

(1) Disolve the cd target, weighing $10-15 \mathrm{mg}$, in a fow milliliters of cono $\mathrm{HWO}_{3}$ in a small btaker. Then all of the material has dissolvod, Evaporate to dryness to drive off excess $\mathrm{HMO}_{3}{ }^{\circ}$

(2) Add 3-4 $\mathrm{mg}$ In and 3-4 mg Ag as the nitrato sol'ns and dilute to $\sim 10 \mathrm{mi}$ with $\mathrm{H}_{2} \mathrm{O}$.

(3) Add 1 I HCl dropwise until the Af is oompletely ppt'd as AfCl. coagulate the pptiby bating and filter through a small i" Watman filter paper in a ihortastemed glass funnel. The filtrate oontains the Cd and In Practions. (The AgCl ppt is worked up separately as described in the procedure for Af from Cd targets, 10. 47-3).

(4) Jake the filtrate amoniaonl and add another 3-4 mg $\mathrm{Ag}$ as the nitrato sol'n. Acidify with Firo and add a few drops of $1 \mathrm{y}$ HCl to insure complete ppt'n of $\mathrm{IgCl}_{\mathrm{g}}$. Coagulate the ppt by heating, fi?tor on ifi2 paper, and disoerd.

(5) Adjust the $\mathrm{pH}$ of the filtrate to 3.5 with $\mathrm{NH}_{4}$ OH and transer to $50 \mathrm{ml}$ separatory funnel.

(6) Extraot the In by shaking with three portions of 0.024 8-hydroxyquinoline in $\mathrm{CH}_{3} \mathrm{Cl}$, drawing the organio layers off into a second separatory funnel aftor each pass. Discard the few drope of mixed sol'n vinioh remain in the stopoock after separation of layers. (The In is contained in this organio layer.)

The Ca remains in the $H_{2} O$ layer and 18 worked up separately as described in the prooedure for Cd from Cd targets, Ho. 48-3.

(7) Treat the organio layers in the second funnel with an equal volume of $\mathrm{pH} 3.5 \mathrm{HCl} 30 \mathrm{l}$ 'n to remove traces of Cd.

(8) Draw off the organic layer into a beaber, add dilute HCl and boll off the $\mathrm{CH}_{3} \mathrm{Cl}$. Add $\mathrm{NH}_{4} \mathrm{OH}$ to $\mathrm{ppt}$ In as the 8-hydroxyquinolate

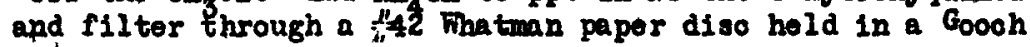




\section{9-1 (pago 2)}

as possible and then dry the disc oarefully under a lamp and mount under tape.

\section{Pemarks :}

See Scott (Std. Heth. Chem. Anal.) for oomplete information on the ppt'n of AECl.

See Sandell (Colorimetrio Determination of Traoes of Netals) for further information on the extraction of In with 8-hydroxyquinoline.

\section{$8 / 18 / 49$}


CHEIICAL SEPARATIONS

Element separated: Indium

Target material: Cd (separated isotopes)

Type of bbdt: Deuterons and protons - 60"

Yield: $\quad 50-75 \%$

Degree of purification: good - at least faotor of 10 from other activities

Advantages : speed

Procedure by: R. C. Lilly

Time for sepin: 10 minutes

Equipment required:

Small beakers

Porcolain filter orveiblo

Filter flasks

Goooh oruo ible \& holders

Glass funnel of filtor ring

Test tube

Procedure :

(1) Dissolve the cd target material, weighing a few milligrams, in a few drops of hot cono. $\mathrm{FNO}_{3}$ in a $20 \mathrm{ml}$ beaker. Add $2 \mathrm{mg} \mathrm{Ag}_{\mathrm{g}}$ and $2 \mathrm{mg}$ In as the nitrate sol'ns. The total volumo at this point should be $5 \mathrm{ml}$.

(2) Add a fow drops of mothyl orange and neutralize with $\mathrm{NH}_{4}$ OH until the sol'n is sliphtly basic (yollow). Coegulate the ppt for a few seconds on a preheated hot plate.

(3) Filter the sample through a poroelain filter oruoible into a $250 \mathrm{ml}$ filter flask, using suction. Tash the ppt with a small amount of $1 \% \mathrm{NH}_{4} \mathrm{NO}_{3}$ sol'n.

(4) Flace the crucible containing the ppt on a rubber filter ring in a glass funnel and arrange a tost tube in the filter flask in such a way that the tip of the funnel drips into the tube. Dissolvo the ppt in $\mathrm{EnO}_{3}$ and suck it through the filter into the test tube.

(5) Lift the tube out of the flask and pour the sol'n into another $20 \mathrm{ml}$ beaker. Repeat the pptin as in (2) and filter the In(OH) 3 through a $/ 42$ thatman filter paper diso held in a Gooch oruoible or a Hirsoh funnel.

(6) Suok the sample as dry as possible and thon pour $2-2 \mathrm{ml}$ acotone through tis paper to remove the residual $\mathrm{H}_{2} \mathrm{O}$. When the paper diso is dry, mount on a card under tape.

Romarks :

In practioe a segment consisting of $\sim 10 \%$ of the total was usually out from the dried paper diso and mounted separately for use in oounting the short half lives; the reminder, which was too aotive to count originally was then used to follow the longer half lives.

$8 / 18 / 49$

P-18-241 
Element separated: Indium

Targot matorial: Antimony ( .5 gm motal)

Typo of bbdt: $184^{\prime \prime} \propto \& \mathrm{D}_{2}$

Yleld: $50 \%$ or greater

Degree of purification: At least factor of 100
Procedure by: Lindner

Time for sep'n: 1-2 hours

Bqui pment required: Lus teroid tube, oentrifuge, cones, tank $\mathrm{X}_{2} \mathrm{~S}, \mathrm{SO}_{2}$

Prooedure:

(1) To the target add 15 drops $27 \mathrm{~N} \mathrm{HP}$ in lusteroid tube in hot water bath. Add cone $\mathrm{HHO}_{3}$ dropwise until dissolved (10 min.) Dilute to $\sim 20 \mathrm{ml}$. 20

(2) Add/mg cach To, Sa, In, Cd, $\Lambda_{E}, \mathrm{Pd}, \mathrm{Ru}, \mathrm{Lb}, \mathrm{I}$ carriors as soluble salts. Add 2 drops cone HCl. Centrifuga.

(3) Diride supn into two equal parts.

(4) Braporate one part to near-dryness. Cool, add $20 \mathrm{ml} 3 \mathrm{II} \mathrm{HCl.}$

(5) Boil the supn to expel $\mathrm{SO}_{2}$, add $5 \mathrm{ml} \mathrm{H}_{2} \mathrm{O}$.

(6) Saturato hot with $\mathrm{H}_{2} \mathrm{~s}$ until $\mathrm{Sb}_{2} \mathrm{~s}_{3}$ pptn completo.

(7) Bvaporate the supn to noar drymose. Take up in $15 \mathrm{ml} 1 \mathrm{~g} \mathrm{NaOH.}$

(8) Wach the Cd and In hydroxide with very dilute KaOB, diseolve in HCl. Add 2 m $\mathrm{Sn}^{+4}$ holdback.

(9) Repent MaOR ppto, dissolve and mako to $15 \mathrm{ml}$ in $2 \mathrm{AHCl}$.

(10) Add 5 ms $\mathrm{Sb}^{+++}, 2$ mo $\mathrm{TeO}_{3}$ and saturato with $\mathrm{H}_{2} \mathrm{~S}$.

(11) Boll supn to expel $\mathrm{H}_{2} \mathrm{~s}$. Add exoess $\mathrm{MH}_{4}$ ar. Contrifugo.

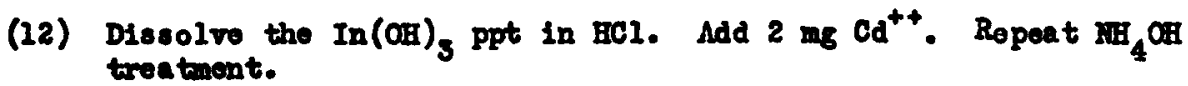

(13) Dissolve the In(OH) 3 ppt in HCI and plato an aliguot.

\section{$8 / 18 / 49$}


Element separated: Indium

Target material: Uranium ( $\sim \mathrm{m}$ )

Type of bbdt: 184" (high energy fission)

Yield: $75-80 \%$

Degree of purification: $10^{5}-10^{6}$ from activities present
Procedure by: Fillinson

Time for sep'n: $\sim 1$ hour

Equipment required: Standard

Procodure:

(1) To aliquot of target solution add 5 of holdback carriers; (Pare Earths, $\mathrm{Ba}, \mathrm{Sr}, \mathrm{Zr}, \mathrm{Bb}, \mathrm{C}_{8}, \mathrm{Te}, \mathrm{Ho}$ and rest of the suifide group metals) plus $5 \mathrm{mg}$ In and Cd carriers.

(2) Adjust acidity to $0.4-0.5 \mathrm{~N} \mathrm{HCl}$ and saturate with $\mathrm{H}_{2} \mathrm{~S}$. Discard

(3) Repeat stcps 1 \& 2 twico. ppt.

(4) Add $\mathrm{NH}_{4} \mathrm{Ac}$ plus acotio acid, ppt In \& Cd suliides.

(5) Dissolve ppt in $/ \mathrm{N}$ HCl and repeat steps 1-4 three times or until the acid sulfide fraction is inaotive.

(6) DHssolve the In \& Cd sulfides from last sulfide pptn in cold $1 \mathrm{~N} \mathrm{HCl}$ (only Cd 2 In sulfides soluble in oold $1 \mathrm{~N} \mathrm{HCl,} \mathrm{Sn} 2$ Sb soluble in hot 1 N HCl).

(7) Add R. E., Ba \& Sr carriers, make slightly alkaline with $\mathrm{NH}_{4} \mathrm{OH}$. Then add HCl until faintly noid.

(8) Add excess NaAc and boil. Contrifuge off the basic indium aootato. (Cd remains in solution)

(9) Dissolve the ppt in diluto $\mathrm{HCl}$. Add $5 \mathrm{mg}$ Cd corrier and repoat stops 7 and 8 . 
Element soparated, $\operatorname{Mg}(\sim 10 \mathrm{~ms})$

Target material: Recovery from chomionl wastes after bbdt including 50 mg $\mathrm{DO}$. $30 \mathrm{mg} \mathrm{Sb}, 20 \mathrm{mg} \mathrm{Cu}$
Prooedure by: W.R. HoDonell

Time for sepin: $3-4 \mathrm{hr}$.

Equipment required: centrifuge

Yiold: 90-95\%

Dogres of purifloation: At least faotor of 100 from metals present in mao ro amount.

Advantages: High rooovery yiold.

\section{Procedures}

(1) Combine wagfgs, orush and dissolve residues in $\mathrm{BCl}(1), \mathrm{HlO}_{3}$ or aqua rogia $(1)$, using alloll rusions $\left(\mathrm{Ha}_{2} \mathrm{CO}_{3}\right.$ or $\left.\mathrm{HaOH}\right)$ whore necessary.

(2) Noutralize with $\mathrm{IH}$ OH or $\mathrm{KaOH}$, make .25-1.0 N aold with $\mathrm{BCl}$, pass in $\mathrm{H}_{2} \mathrm{~s}$ to saturation, ppt black (usually) acid sulfido group + sulfir. Contrifruge, decant.

(3) Add $1500 \mathrm{Na} \mathrm{S}$ soln (2) to ppt. Heat $60-80^{\circ} \mathrm{C}$ with stirring. Add $16 \mathrm{ml}$ hot $0.6 \mathrm{~N}$ NaOH, oentrifuge, decant. Whoh with 2nd portion of $\mathrm{Na}_{2} \mathrm{~S}$. Combine filtrates. Acidify siowly with BCI to noutral litmus, then make .25-1 11 aoid. Saturate with $\mathrm{B}_{2}$ S. Centrifuge, docant.

(4) Add oopg, $\mathrm{BCl}$, warm with stirring to dissolve sulfides and coafrul to sulfur (3). Contrifuge, decant. Whash sulfur with hot $6 \mathrm{~N} \mathrm{HCl.}$ Combine solutions, whioh now oonta in $\mathrm{Sn}, \mathrm{Sb}$ (and $\mathrm{As}$ if any originally presont) and only small amounts of Cu group metals.

(5) Do the tin antimony separation as outlined in $54 f^{2}$ prooedure (seleotive sulfide ppt or $\sim$ po reduotion, eto.)

\section{Rernarbe:} (1) Avoid boiling cono. ohloride solutions of $\mathrm{Sn}$, since $\mathrm{SnCl}_{4}$ is
somewhat volatile.

(2) $\mathrm{Ha}_{2} \mathrm{~S}_{\mathrm{T}}$ is used instead of $\left(\mathrm{MH}_{4}\right)_{2} \mathrm{~S}_{4}$ booause it affords a better sepafation from Cu, a major dontriminant. (Rof. A System of Chemioal Analys is, E. H. Swift, Prontico-Ball, Inc., Hew York, 1940 p. 215.) Speoifications for $\mathrm{Ha}_{2} \mathrm{~S}_{3}$ soln: dissolve $480 \mathrm{~g} \mathrm{Na} \mathrm{Na}_{2} \mathrm{~S} 9 \mathrm{H}_{2} \mathrm{O}$ $+40 \mathrm{~g}$. NaOH in mintmum nmt of water, dissolvo $16 \mathrm{~g}$ powderod sulfur in this soln, dilute to 1 liter.

(3) A large quantity of sulfur is present in the ppt. Haverer, it coagulates very well on hoating in aoid solution, while adsorbing very littlo of the sulfide, allowing satisfactory cxtraotion.

(4) Traces of Cu are dissolved by $\mathrm{Na}_{2} \mathrm{~s}$ solution. This, howevor, follows the $\mathrm{Sb}$ in the subsequent $\mathrm{Sb}^{2} \mathrm{Sn}$ separations. (Selectivo sulfide pptn or Fe reduotion). 
$50-2$

CHEUICAL STPARATIONS

Element separated: Tin $_{\text {In }}$

Target material: Tin (plus $\mathrm{Cu}$ of target holder)

Type of bbdt: low energy $d, p, n$

Procedure by: Nowton

\& HoDonell

Time for sep'ns $1 \mathrm{l} / \mathrm{h} \mathrm{hrs}$.

Equipment required: oentrifuge, hot plate, glassware

Yield: $\quad 50-70 \%$

Degree of purification: $\sim 10^{6}$

Advantages: Simpler than oxalate or distillation prodedures

Procedure:

(1) Dissolve target in HCl, heating (1) and adding drop $\mathrm{Fr}_{2}$ or fow drops of $\mathrm{HNO}_{3}$ where neoessary to effect rapid solution 2$)^{2}$ Add $10 \mathrm{mb}$ Sb, In carriers.

(2) Wre 3-4 NHCl. Add iron ponder to exoess (hydrogen evolution), heat with stirring,ppt $\mathrm{Sb}$ and $\mathrm{Cu}$ metal (blaok), filter by vaoum through sintered glass filtering oruoible.

(3) To filtrate add drop of $\mathrm{Br}_{2}\left(\mathrm{Fe}^{++} \longrightarrow \mathrm{Fe}^{++}, \mathrm{Sn}^{++} \longrightarrow \mathrm{Sn}^{++++}\right.$ Deutralize with $\mathrm{NH}_{4} \mathrm{OH}$ to appearanoe of red $\mathrm{Fo}(\mathrm{OH})_{3}$, add just onough $\mathrm{HCl}$ to redissolve $\mathrm{Fo}(\mathrm{gH})_{3}$ (ooidity $<1 \mathrm{~N}$ ), pass in $\mathrm{H}_{2} \mathrm{~S}$ to saturation, ppt yellow $\mathrm{SnS}_{2}$

(4) Dissolvo $\mathrm{SnS}_{2}$ in HCl (3 oc of $12 \mathrm{~N}$ ) by hoating (1), stirring Add $10 \mathrm{mg}$ Sb oarrier, stirring. Dilute to $2.5 \mathrm{Il}$ coid ( $\sim 14 \mathrm{co}$ ), hoat in bolling water bath, pass in $\mathrm{H}_{2} \mathrm{~S}$ to saturation, ppt orange $\mathrm{Sb}_{2} \mathrm{~S}_{3}$. Centrifuge hot (SnS, may ppt in cold), deoant. Dilute to $1.5 \mathrm{x}^{2}$ ( $\sim 25 \mathrm{cc}$ ), pass in $\mathrm{H}_{2} \mathrm{~S}$, ppt $\mathrm{SnS}_{2}$ (yoliow). Repent step 3 onoe or twico.

(5) Dissolve $\mathrm{SnS}_{2}$ in $10012 \mathrm{~N} \mathrm{HCl}$. Add Fo ${ }^{+++}$carrier $(\$ 0 \mathrm{mg})$. Dilute slightly, add excess NaOH with stirring, heat well $(4)$. Centrifuge. Add further In and Fe (5 mg each) oarrier to basio soln, ppting hydroxides. Contrifuge on top of previous ppt,deoant. Repeat (4) if necessary.

(6) Aoldify to 1 N HCl. Pass in $\mathrm{H}_{2} \mathrm{~S}, \mathrm{ppt} \mathrm{SnS}_{2}$. Contrifuge, decant. Dissolve ppt in minimum cono $\mathrm{HrO}_{3}^{2}$, add 3-5 co fuming Hro, a knifo point of $\mathrm{NH}_{4} \mathrm{HO}_{3}$. Boil several minutes to ppt white meta-stannio acid. Evapórate :Iiquots of the slurried soln on watohglass and mount for counting. To determine chemical yield dilute after pptine $\mathrm{H}_{2} \mathrm{SnO}_{3}$, add filter paper pulp. filter through ashless paper, rêoliff̧ filtrate till olear, ary, and ignite to $\mathrm{SnO}_{2}$. Weigh a.s $\mathrm{SnO}_{2}$ 
Remarks:

(1) Avoid boiling concentrated $\mathrm{Cl}^{-}$solns of $\mathrm{S}_{\mathrm{n}}$; $\mathrm{SnCl}_{4}$ appreciably rolatile. (Also $\mathrm{SbCl}_{3}, \mathrm{SnCl}_{3}$, otc.)

(2) A black residue replates out on the dissolvine Sh, sometimes necessitating a moghanical agitation of the Sn surface.

(3) InS 3 ppts properly only at $6.05 \mathrm{~N} \mathrm{HCl,} \mathrm{however,} \mathrm{it} \mathrm{is} \mathrm{partially}$ co-preolpitated at higher acidities with other sulfides of the Sn and Cu groups.

(4) In (OH $)_{3}$ is peptized by fixed alkali hydroxides but reppts on boliling. It is very slightly amphoterio.

(5) Do not use Pt orucible for ignition as Sn tal is produced which alloys badly with Pt. Poroelain oructble should be used.

(6) $\mathrm{SnO}_{2}$ difficult to dissolvo after lgniting, has been found io go into $\mathrm{BCl}$ soln after fusion with $\mathrm{Na}_{2} \mathrm{CO}_{3}$ (anhyd.) in $\mathrm{Pt}$ oruoiblo. 


\section{CHEMICAL SPPARA TIONS}

Elemont separated: Tin

Targot material: $S b(\sim .5 \mathrm{gm}$ motal)

Type of bbdt: 184 " $\alpha$ and $D_{2}$

Yiold: $50 \%$ or groater

Degree of purification: At l cast factor of 100.

Procedure:

(1) To tho targot add 15 drops $27 \mathrm{~N} \mathrm{HF} \mathrm{in} \mathrm{Ius} \mathrm{toroid} \mathrm{tube} \mathrm{in} \mathrm{hot} \mathrm{water}$ bath. Add cono $\mathrm{HNO}_{3}$ dropwise until dissolvod (20 min.) Diluto to $\sim 20 \mathrm{ml}$.

20

(2) $\Lambda \mathrm{dd} / \mathrm{mg}$ each $\mathrm{Te}, \mathrm{Sn}, \mathrm{In}, \mathrm{Cd}, \mathrm{Ag}, \mathrm{Pd}, \mathrm{Ru}, 150, \mathrm{Y}$ carriers as soluble salts. $\Lambda$ dd 2 drops cono HCl. Contrifugo.

(3) Divide supa into two equal parts.

(4) Evaporate one part to near-dryness. Cool, add $20 \mathrm{ml} 3 \mathrm{~N} \mathrm{HCl.}$

(5) Bo1l the supn to oxpel $\mathrm{SO}_{2}$, add $6 \mathrm{ml} \mathrm{H}_{2} \mathrm{O}$.

(6) Saturato hot with $\mathrm{H}_{2} \mathrm{~s}$ until $\mathrm{Sb}_{2} \mathrm{~s}_{3}$ ppto oompleto.

(7) Evaporate the supn to noar drymess. Take up in $15 \mathrm{ml} 1 \mathrm{II} \mathrm{HaOH.}$

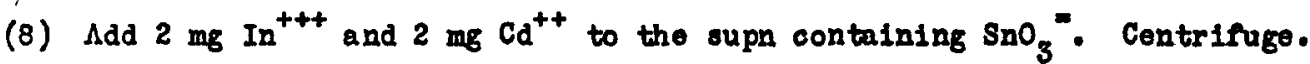

(9) Neutralize the supn dropwise with cone. $\mathrm{H}_{2} \mathrm{SO}_{4}$, make $0.3 \mathrm{II}$ in $\mathrm{ECl}$, saturate with $\mathrm{H}_{2} \mathrm{~S}$.

(10) Dissolve tho $\mathrm{SnS}_{2}$ in $2 \mathrm{ml}$ cono $\mathrm{BCl}$, boil to expel $\mathrm{H}_{2} \mathrm{~s}$ and diluto to $12 \mathrm{ml} .2$ Reject any undissolved material (Sb).

(11) Add $2 \mathrm{mg} \mathrm{Sb^{+++ }}$ carrier to the $\mathrm{Sn}^{+4}$ solution and saturato with $\mathrm{H}_{2} \mathrm{~S}$.

(12) Bo1l to expel $\mathrm{H}_{2} \mathrm{~S}$, make $0.3 \mathrm{~N}$ in $\mathrm{HCl}$. Re-saturate with $\mathrm{H}_{2} \mathrm{~S}$.

(13) Dissolve $\mathrm{SnS}_{2}$ in minimum $\mathrm{HCl}$.

(14) Evaporato an aliquot to aryness. Tako up in $10 \mathrm{ml} 16 \mathrm{~N} \mathrm{HNO}_{3}$, boll to near-dryness, repeat several times. Filter.

(15) Transfer the $\mathrm{SnO}_{2} \cdot \mathrm{XH}_{2} \mathrm{O} \mathrm{ppt}$ to a oruoiblo. Ignito $1 \mathrm{hr}$ to $\mathrm{ShO}_{2}$ and wolgh.
$8 / 18 / 49$

P-18-218 
$60-4$

\section{CEBSICICAL SEPARAT IOAB}

Elomont separated: IIn

Targot matorials Thorium motal (.1-1 gm)

Type of bbdts $60^{n}$ als
Prooedure bys Hewton

Timo for sep'ns $11 / 2 \mathrm{hrs}$.

Equipmont requirods Standard, $\operatorname{tank} \mathrm{H}_{2} \mathrm{~S}$

Yiold: $\sim 66 \%$

Degree of purification: $10^{6}$ to $10^{6}$

Procedure: The Th metal is dissolvod in cone HCl + a fer drons .2 y sofution/ to elear up black residue. The ECl 10 diluted to $2 \underline{\underline{Z}}$ and an aliquot taken.

(1) To sample add $20 \mathrm{mE} \mathrm{Sn}^{+4}$ oarrier in $2 \mathrm{~KB} \mathrm{BC}$. Diluto solution to $10 \mathrm{ml}$ and $1 \mathrm{gl}$ in ECl. Heat and pass in $\mathrm{H}_{2} \mathrm{~S}$. Ppt $\mathrm{SnS}_{2}$.

(2) Dissolve SnS, in 1 ml oono Bcl. Boil out $\mathrm{H}_{2} \mathrm{~S}$. Ldd 10 w Sb carrior. Lifke solution 2-2.5 N $\mathrm{HCl}$, heat and pass in $\mathrm{H}_{2} \mathrm{~s}$. Koop hot (if oooled $\mathrm{SnS}_{2}$ ppts). Coñtrifuge off $\mathrm{Sb}_{2} \mathrm{~s}_{3}$.

(3) Add $1 \mathrm{ml} \mathrm{N} \mathrm{MH}_{4}$ OH to supernate from 2. Heat and pass in $\mathrm{H}_{2} \mathrm{~S}$. ppt $\mathrm{SnS}_{2}$

(4) Dissolve $\mathrm{SnS}_{2}$ in oono $\mathrm{HCl}$, dilute, boil out H,S. Add 5 mg each $\mathrm{Fu}, \mathrm{Zr}, \mathrm{Sb}$, Cd and Fo. Add $6 \mathrm{~N}$ HaCh unt1l quito basio. ppt hydroxides. Add more $\mathrm{Fe}$ and oentringe down on top of first hydroxide ppt.

(5) Hake supernate aoid, pass in $\mathrm{H}_{2} \mathrm{~S}$. Ppt $\mathrm{SnS}_{2}$.

(6) Repoat Sb scavonging in (2) and (3).

(7) Dissolvo $\mathrm{SnS}_{2}$ in cono $\mathrm{HDO}_{3}$. Add three drope ( $2 \mathrm{~m}$ ) Ru oarrier, $1 \mathrm{gm} \mathrm{mi}_{4} \mathrm{HO}_{3}$ (solid) boll until $\mathrm{SnO}_{2}$ ppts.

(8) Filtor with afd of filtor paper pulp and ignite to $\mathrm{SnO}_{2}$ in a poroela in orucible. Helgh and mount as $\mathrm{SmO}_{2}$.

Remarks: This motinod has boon describod proviously (Phys. Rev. 75, 17 (1949)).

To standardize $\mathrm{Sn}$ carrier: To $5 \mathrm{ml}$ (50 mg) $\mathrm{SnCl}_{4}$ olution add excess $\mathrm{MH}_{4} \mathrm{OH}$. Centrifure and wash ppt onoo with $\mathrm{H}_{2} \mathrm{O}$. Ro-centrifuge. Dissolvo ppt in $\mathrm{ErO}_{3}$, boil to ppt $\mathrm{H}_{2} \mathrm{SnO}_{3}$. Filter and ignite to $\mathrm{SnO}_{2}$.

$8 / 23 / 49$ 
GHILICAL SERARATIOIS

Elomont soparatods Antimony

Prooodure by: Coookormann

Targot toricl: $\cap 1$ g Bi motal

Timo for sop'n: in 1-3 hrs.

Typo of bbdt: 184" all partiolos

Equipmont roquirod: Contrifuge, tubos, HCl tank, clcotrolysis octup, $\mathrm{H}_{2} \mathrm{~S}$ tank, $\mathrm{SO}_{2} \operatorname{tank}$

Y10ld: Varlablo, low for prooodurcs 1 \& 2 .

Dogrco of purifioat 10n: Dnsatisfootory for bismuth bbdt.

Advantagos \& Prooodurcs 2 \& 3 will probably work for othor bbdts. Mo. 2 10 fast and may bo good with $1-2$ ng oarrior.

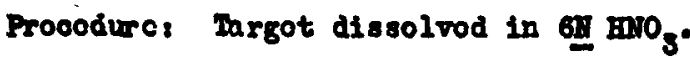

Ho satisfaotory proooduro was found but tho following throo wore triod.

(1) Proolpitations of $\mathrm{Sb}_{2} \mathrm{O}_{5}$ with fuming $\mathrm{HrO}_{3}$, distillations of $\mathrm{SbCl}$ Irom $\mathrm{H}_{3} \mathrm{SO}_{4}$ in an $\mathrm{HCl}$ s twam, prcolpitations of $\mathrm{Sb}_{2} \mathrm{~S}_{3}$ from hot $3 \mathrm{H} \mathrm{HCl}$, soparatiofs of $\mathrm{AsCl}_{3}$ by dietillation, and $\mathrm{As}_{2} \mathrm{~s}_{3}$ predipitation.

(2) Proolpitations of $\mathrm{Sb}_{2} \mathrm{O}_{5}, 0200$ trolyeis of $\mathrm{SbH}_{3}$ from $6 \mathrm{II} \mathrm{H}_{2} \mathrm{SO}_{4}$ with

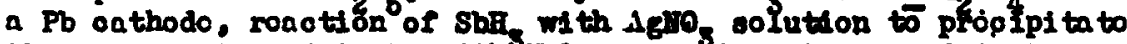

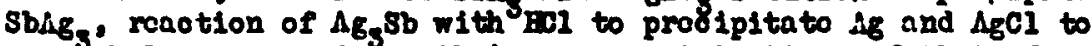
givo $\mathrm{SbCl}_{3}$, son vong ing with $\mathrm{As}_{2} \mathrm{~S}_{3}$, proolptitations of $\mathrm{Sb}_{2} \mathrm{~s}_{3}$ from hot 3I HCP.

(3) Proolpitations of $\mathrm{Sb}_{2} \mathrm{O}_{5}$ and $\mathrm{Sb}_{2} \mathrm{~S}_{3}$ scaronging with $\mathrm{As}_{2} \mathrm{~s}_{3}, 10 \mathrm{~S}_{3}, \mathrm{T0}$, Fo $(\mathrm{OH})_{3}$ from $\mathrm{KOH}$ solution, and ${ }^{2} \mathrm{BI}_{2} \mathrm{~B}_{3}$ from $\mathrm{K}_{2}$

Romarks, Proocduro 1 is diffioult and purity was unsatisfactory. No. 2 gavo poor yiclds with $10 \mathrm{mg}$ carrier - sb $^{\circ}$ dopositod on tho $\mathrm{Pb}$ onthodo. INo. 3 is slow, should cloan up tho sb but didnit. $\mathrm{Sb}^{+5}$ oxtraots woll into 1sopropyl other from 6-9N $\mathrm{HCl}$ but not $\mathrm{Sb}^{+3}$.

$7 / 29 / 49$

P-18-102 
CHEMTC:L SEPARATIONS

Elomont soparated: Antimony

Parent material: IIn

18lking procoduro (sb from low onorgy $p, d$, or $n$ produood $\mathrm{Sn}$ activity fraotions)
Proceduro by: Newton a Honoll

Timo for sop'n: 2 hrs.

Bquipmont roquired: contrifugo, hot plato, glasswaro

Yiold: $60-80 \%$

Degroo of purification: it lenst factor of $10^{4}$ from Sa.

Prooeduro:

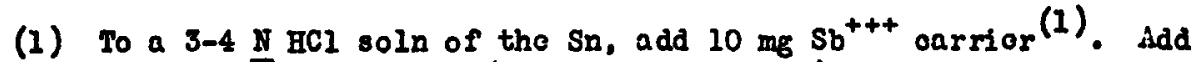
iron powdor to oxcoss (hydrogen evolution), heat with stl rring, ppt $8 \mathrm{~b}$ motal (blaok). Filtor by raouum through sintorod glass filtoring orucible.

(2) Dissolvo $\mathrm{Sb}$ in aqua rogia, diluto to $1 \mathrm{~N}$ aoid, pass in $\mathrm{H}_{2} \mathrm{~S}$ and ppt $\mathrm{Sb}_{2} \mathrm{~S}_{3}+\mathrm{S}$. Dissolvo tho sulfido out of tho sulfur with cono. BCI (warming and stirring). Dilute to $8 \mathrm{II} \mathrm{HCl}$ hoating to expol $\mathrm{H}_{2} \mathrm{~S}$ if $\mathrm{Sb}_{2} \mathrm{~s}_{3}$ roppts on dilution. Contrifügo, dooant.

(3) Idd 10 mg $\mathrm{Sn}^{+4}$ carrior to filtrate. Heat in boiling wator bath, pass in $\mathrm{H}_{2} \mathrm{~s}$ to saturation, ppt orango $\mathrm{Sb}_{2} \mathrm{~s}_{3}$. Contrifugo hot, docant. Dissolvo $\mathrm{Sb}_{2} \mathrm{~S}_{3}$ in oono. HCl. Diluto to 3 HCl. Ropoat stop (3) twico moro. 3 .

(4) $\mathrm{Sb}_{2} \mathrm{~S}_{3}$ mountod aftor thorough washing with distillod wator on small watohglass or op 2 filtor paper by suotion filtration, followod by gontlo hating.

Romarke,

(1) Indium may bo scarongod out of this milking by adding $10 \mathrm{mg}$ In oarrior to initial Sn solution (stop 1), repocting tho Fo reduotion if the amount of In aotivity prosont warronts 1 t.

(2) Tho Sb sulfido should not bo roliod upon for aocurato ylold dotermination. 


\section{CHEIITCLL SEPARATIONS}

Blament separated: Antimony

Procodure bys Lindner

Target terial: Antimony ( $\sim .5 \mathrm{~mol}$ )

Time for sep'n: 1-2 hours

Type of bbdt: $184^{\prime \prime} a$ and $D_{2}$

Equipment required, Lustoroia tubes, contrifuge, cones, tank $\mathrm{SO}_{2}, \mathrm{H}_{2} \mathrm{~S}$

Yield: $\sim 75 \%$

Degreo of purification: Lt least ractor of 100

Prooedure:

(1) To the target add 15 drope 27 If In lustoroid tube in hot water bath. Add cono $\mathrm{BMO}_{\mathrm{g}}$ dropules until diseolvod (10 min). Dilute to $\sim 20 \mathrm{ml}$.

(2) Add/mg each Te, Sn, Ir, Cd, Af, Pd, Pu, 16, I carriers as soluble salts. Add 2 drops cono HCl. Centringe.

(3) Divide aupa into two equal parts.

(4) Evaporate ono part to noar-dryness. Cool, add $20 \mathrm{ml} 3$ II HCl. Saturate with $\mathrm{SO}_{2}$ gas 10 minutos. To ppts.

(5) Botl the supn to expel $\mathrm{sO}_{2}$, add $5 \mathrm{ml} \mathrm{B}_{2} \mathrm{O}$.

(6) Saturato hot with $\mathrm{H}_{2} \mathrm{~S}$ until $\mathrm{Sb}_{2} \mathrm{~s}_{3}$ pptn completo.

(7) Thsh ppt with 2 II HCl sat'd with $\mathrm{H}_{2} \mathrm{~s}$. D1s Evap to dryness Fith air stroam in hot water beth, add $30 \mathrm{ml} 2$ II BCi, 2 as each of $\mathrm{Sn}$, In \& Cd narriers.

(8) Saturato hot with $\mathrm{H}_{2} \mathrm{~s}$ and ropeat oyole.

(9) Dissolve the $\mathrm{Sb}_{2} \mathrm{~s}_{3}$ ppt in $2 \mathrm{ml}$ cono. HCl.

(10) Noigh aliquot of samplo as $\mathrm{Bb}_{2} \mathrm{~s}_{3}$

\section{$8 / 18 / 49$}


Element separated: Intimong

Parget material: Th

Type of bbdt: a fission, 60"
Procedure by: Newton

Time for sep'n: Several hrs. 1-2 hrs, attention

Equipment required: eleotrolysis oell

Yield: $0-25 \%$

Degres of purifioation: $10^{6}$ as claimed by Wilikinson

Procedure: The Th metal is dissolved in cono. $\mathrm{HCl}+$ a few drops of $2 \mathrm{M}$ solution of $\left(\mathrm{NH}_{4}\right)_{2} \mathrm{SiF}_{6}$ to clear un the black residue. The HCI is dilpted to $2 \mathrm{~N}$ and an aliquot taken.

(1) Add 10 mg Sb carrier.

(2) Whe $2 \mathrm{~N}$ in $\mathrm{HCl}$, pass in $\mathrm{H}_{2} \mathrm{~S}, \mathrm{ppt} \mathrm{Sb}_{2} \mathrm{~S}_{3^{*}}$

(3) Vash $\mathrm{Sb}_{2} \mathrm{~S}_{3}$

(4) Dissolve in conc. $\mathrm{H}_{2} \mathrm{SO}_{4}+$ few drops $\mathrm{HNO}_{3}$, fumo.

(5) Dilute, make $\sim 4 \mathrm{~N} \mathrm{H}_{2} \mathrm{SO}_{4}$. Dlectrolyze to lead cathode from Pt anode. Collect $\mathrm{SbH}_{3}$ in $\mathrm{AgNO}_{3}^{2} \cdot{ }^{4} \mathrm{Ppt} \mathrm{SbAg}_{3} \cdot$

(6) Centrifuge and wash $\mathrm{Ag}_{3} \mathrm{Sb}$.

(7) Treat ppt with 1 N $\mathrm{HCl}$ to dis80170 Sb, residue $\mathrm{Ag}+\mathrm{AgCl}$. Centrifuge.

(8) From Sb sol, in $1 \mathrm{~N} H C l$ ppt $\mathrm{Sb}_{2} \mathrm{~S}_{3}$. Fash three times with $5 \mathrm{ml} \mathrm{H}_{2} \mathrm{O}$, three times with $\overrightarrow{5} \mathrm{ml} E$ tOH, dry at $110^{\circ}$ and weigh.

Remarks :

(1) The less Sb carrier used the better. Add no holdback carriers as these interfere with the operation of the lead oathode.

(2) Electrolysis is very sensitive to condition of lead oathode. $\mathrm{SbH}_{3}$ erolution can be followed by amount of $\mathrm{SbA}_{3}$ ppt in $\mathrm{AgNO}_{3}$ solution.

(3) If $\mathrm{SbH}_{3}$ evolution ceases, more can be brought over if leacs are reversed for a while to decontaminate the lead and then remreversod to male Po the cathode again. Eventually this procedure failo.

In step (1) make sure the Sb oarrier and tracer exchange. One way to insure exchange is to oxidize the $\mathrm{Sb}$ with $\mathrm{Br}_{2}$ to the +5 state and then reduce it to the +3 state vith hydrazino before precipitating the sulfide.

This prooeure has been desoribed proviously (Thvs. Rev. 75, 17 (1949)). $8 / 11 / 49$ 


\section{CHEUICAL SBPARATIOIS}

Eloment soparatod: To $(n 100 \% / \mathrm{m})$

Prooodure by: Marques

Target matorial: I $\left(\sim 10^{8} \mathrm{c} / \mathrm{m}\right)$

Timo for sop'n: $3-4 \mathrm{hrs}$.

Typo of bbdt: Milking oxperimont

Equipmont roquired:

Contrifugo tubos.

Yiold: $\operatorname{ns} 80 \%$

Dogrce of purification: 4 cxtas givo a samplo with $\backsim 300 \mathrm{o} / \mathrm{m}$ to a approx. 100 o/m I.

Procodure:

(1) Add to tho I sol'n, $10 \mathrm{mg}$ To carrier as $\mathrm{Ka}_{2} \mathrm{TrO}_{4}$, aoldify with $\mathrm{H}_{2} \mathrm{SO}_{4}$ until brown oolor of $\mathrm{I}$ and add $\mathrm{BO}_{2}{ }^{-}$to oxidizo to $\mathrm{I}_{2}$.

(2) Brtraot the $\mathrm{I}_{2}$ vith oqual volume $\mathrm{CCl}_{4}$.

(3) Ldd soveral times moro $I^{-}$and extraot the $I_{2}$ with $\mathrm{CCl}_{4}$.

(4) Ppt To by bubbling in $\mathrm{SO}_{2}$ gas.

(5) Ropoat tho cyclo by dissolving Te in cono. Brrog, adding $I^{-}$, oto.

(6) Contrifugo tho To ppt and filtor.

(7) Plato and oount as To.

Romarks :

Tho To ppts soom to sarry oach timo a littlo bit of I actioity. It requires soveral oyoles to got it puro.

$7 / 27 / 49$

$P-18-74$ 
Targot matorial: 1 \& BI motal

Typo of bbdt: 184" all partiolos
Prooodurc by: Goockormann

Timo for sepinenl hr.

Equipront requirod, contrifrugo, tubos, $10 \mathrm{C}, \mathrm{SO}_{2}$ tank, $110^{\circ}$ ovin

Y101d: in 60\%

Degreo of purification: Dooontamination factor $>10^{4}$ from fission and spallatlon produotio.

Advantages: Pair yiold of puro to, mirly rapidly.

Proocduro:

(1) To aliquot of $800 \mathrm{~g}$ sol' $\mathrm{n}$ of tarect add $10 \mathrm{mg}$ To and Sc and conocntretod BBr. boll noarly to drynose a fow tinos. Tako up roulduo in 10 ml oonoontratod BCl, add 80 , prooipt ta to $S 0^{\circ}$ with $\mathrm{SO}_{2}$ in an 100 bath.

(2)

Diuto 13 HCl, hoat, and proolpstato $\mathrm{Tc}^{\circ}$ with $\mathrm{SO}_{2}$, oontrifugo

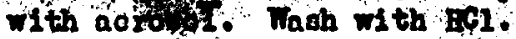

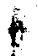

(3) Dlegolive $10^{\circ}$ in a fow drops $\mathrm{Bno}_{3}$, ovaporato oxtooss aold, diluto

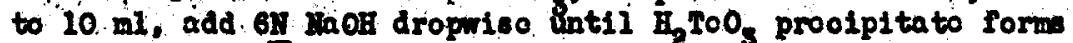
and thon redissolvos, 10 drope oxocss. Sedvengo wh th $1-2$ mE Fo(OH) 3 .

(4) supormatant $\mathrm{SI}$ in BCI and procipitatc to ${ }^{\circ}$

(5) Bapopt $569,0^{\circ}$ and $\mathrm{Po}(\mathrm{OH})_{3}$ prooipitations screral timos.

(6) Bltor last $T e^{\circ}$ prool pitato, wash throo times with 5 ul Ho, throo time gith 5 mi $C_{2}$ OH $_{5}$ throo times with.5 mi othir, dry 90 min. at $i 10^{\circ} \mathrm{C}$. Weith o $0^{5} \mathrm{To}^{\circ}$ ?

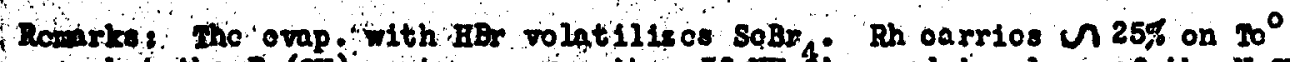
but the po(oH) ppta remotio it. If $\mathrm{KH}^{4}$ is usod in placo of tho laor,

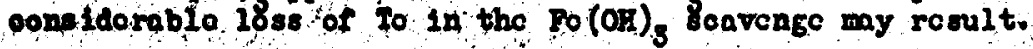


CHEMICA L SEPARATIONS

Element soparated: Tellurium

Target material: Sb ( $N .5 \mathrm{gm}$ motal)

Type of bbdt: $184 " \mathrm{D}_{2}$ a

Yield: 90\%

Dogree of purification: At least fector of 100
Procedure by: Lindner

Time for sepin: $\sim 1$ hour

Equipment required:

Lusteroid tubo, oentrifuge, coner, tanic $\mathrm{SO}_{2}$

Prooedure:

(1) To the target add 15 drops 27 IIF in lus torold tube in hot water bath. Add oono. $\mathrm{HNO}_{3}$ dropwiso until dissolved (10 min). Dilute to $20 \mathrm{ml}$.

(2) Add/ug each $\mathrm{Te}, \mathrm{S}_{\mathrm{n}}, \mathrm{In}, \mathrm{Cd}, \mathrm{Ag}_{\mathrm{G}}, \mathrm{Pd}, \mathrm{Ku}, 1 \mathrm{H}, \mathrm{Y}$ carriers as soluble salts. Add 2 drops cono BCl. Contrifuge.

(3) Difide supm into two equal parts.

(4) Evaporate one part to near-dryness. Cool, add $20 \mathrm{ml} 3 \mathrm{II} \mathrm{HCl.} \mathrm{Sat-}$ ura to with $\mathrm{SO}_{2}$ gas 10 minutes. To ppts.

(5) Wash the ppt with water and dissolve in one drop oono. $\mathrm{BrO}_{3}$.

(6) Add $15 \mathrm{ml} 3 \mathrm{NHCl}, 2 \mathrm{mg}$ each, Sb, Sn, In, Cd holdbaok. Saturato with $\mathrm{SO}_{2}$ gas.

(7) Ropeat steps $5 \& 6$.

(8) Fash the ppt and weigh as Te.

$8 / 18 / 49$

$P-18-221$ 
Blomont sopara tod, Tollurium

Target material: Thorium metal (.1-1 gm)

Type of bbdt: $60^{n}$ als

Yield: $\sim 80 \%$

Dogree of purifleations $\sim 10^{6}$

Procedure: The In $m$ tal is dissolved in cono $\mathrm{HCl}+$ a fer drops of $2 \mathrm{H}$ solution ( $\left.\mathrm{MH}_{\mathrm{A}}\right)_{2} \mathrm{SiF}_{6}$ to olear up black residue. The ECl is diluted to 6 II and an alquot tabon.

(1) To samplo add 10 as $T_{0}$ and diluto to $3 \mathrm{IHCl}$. Heat and ppt To with $\mathrm{SO}_{2}$.

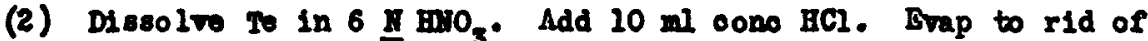
$\mathrm{ENO}_{5}$. Repert ovaporation. Diluto to $3 \mathrm{~F} \mathrm{ECl}$ and ppt To again wth $\mathrm{SO}_{2}$.

(3) Dis80 Ive Te in $6 \mathrm{~N} \mathrm{EHO}_{3}$. Evaporate and dilute to $10 \mathrm{ml}$. Add $6 \mathrm{~N}$ $2 \mathrm{H}_{4}$ OH dropwise until $\mathrm{H}_{2}^{3} \mathrm{TeO}_{3}$ ppt diseplpes. Then add 10 drope

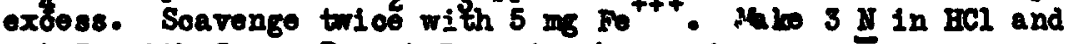
ppt To with $\mathrm{SO}_{2}$. Bopeat To pptn (stop 2).

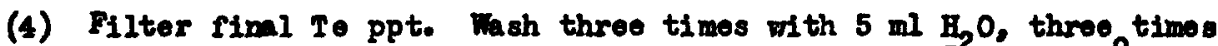
with $5 \mathrm{ml}$ EtoH and three times with $5 \mathrm{ml} \mathrm{Bt}_{2} 0$. Dhy at $110^{\circ}$ and wolgh as 20 .

Bomarics: This mothod has beon desoribed proviously (Fhys. Rev. 75, 17 (1949).

10 me $=10 \mathrm{mg} \mathrm{Te}^{\circ}$

I eannot be milked from Te by ppting the To by this procedure.

Preparation of oarrier solution: Add cono. $\mathrm{HMO}_{3}$ to $10-11 \mathrm{~mm} \mathrm{Te}$ motal In a L60 mI erlenmeyer and heat until Te colses to dissolve. Eraporate to a volume of $2-3 \mathrm{ml}$ (residue left) and add $10 \mathrm{ml}$ cono BCl. Evaporate to a volume of $2-3 \mathrm{ml}$. Add $10 \mathrm{ml}$ more HCl and reevaporn to to expel $\mathrm{ENO}_{3}$. Take up solution in 1 liter of $3 \mathrm{MHCl}$. Filter if not olear.

Standardisation: Take $5 \mathrm{ml}$ oarrier in $125 \mathrm{ml}$ erlenmeyer. Add $40 \mathrm{ml}$ 5 H HCl. Heat nearly to boiling. Saturate with $\mathrm{SO}_{2}$ until Te is well ocagulated. Boll gently for 1 minute. Filter onto a sintered glass orucible, wash three times with hot $\mathrm{H}_{2} \mathrm{O}$, three tims with $95 \% \mathrm{Bt}$. throe times with $E t_{2} O$. Dry at $110^{\circ}$ for 10 minutes. Weigh. 
Elcmont scparatod: I ( $120^{-6}$ barns oross soction)

Targot matorial: $\operatorname{sn}(\sim) 1 \mathrm{gm})$

Typo of bbdt: $184^{\prime \prime}$ a \& p

Yiold: $70-80 \%$
Prosoduro by: Narques

Time for sopin: 50 min.

Equipmont requirod: 100 oo distillation flask separatory funnols ocntrifugo tubes

Degroo of purifioation: Loss than $2 \%$ impurity in final I samplo.

Advantages: Fast. Nakes possiblo sop'n of a very small amount of puro I from largo amounts of othor aotivities.

Provodure:

(1) Add 10 mg $I^{-}$oarricr and target foll to distillation flask.

(2) Add $\mathrm{L} 25 \mathrm{ml}$ cono. $\mathrm{H}_{2} \mathrm{SO}_{4},\left(\mathrm{H}_{2} \mathrm{SO}_{4}\right.$ should bo oold) to dissolvo the $\mathrm{S}_{\mathrm{n}}$ Dissoltre Sn

(3)/ aad distill simaltanoously, 001looting $I_{2}$ in 0.5-1I MaOH ooln.

(4) Moidify with $\mathrm{H}_{2} \mathrm{SO}_{4}$ until lodino turne brown and oxidiso with $\mathrm{HWO}_{2}$. $\left(\mathrm{NaHO}_{2}\right.$ in $\left.0.01 d^{2} \mathrm{sol}_{\mathrm{n}}\right)$. Extraot with equal rolumo $\mathrm{CCl}_{4}$.

(5) Fash I' into HaOH sol'n.

(6) Ropoat $\mathrm{HaOH}-\mathrm{CCl}_{4}$ oyoles as many timos as wishod. (Throo oyolos gavo purity 118tod above.)

(7) Soidify last $\mathrm{HaOH} 801$ 'n with $\mathrm{H}_{2} \mathrm{SO}_{4}$ and reduoe with $\mathrm{SO}_{2}$ gas. Blow air through soln to expol most of $\mathrm{SO}_{2}$. Add $x \mathrm{Ag}+$ and a for drops of cono. $\mathrm{HIO}_{3}$.

(8) Hoat in wator bath and fl lter.

(9) Plato and oount as AfI.

\section{Romarks :}

Wost of tho 208 s in this prooodure oomos in tho distillation proooss.

Ioo oold $\mathrm{B}_{\mathrm{S}} \mathrm{SO}$ used in (2) to allow assombly of distillation apparatus boforo solution of targot starts.

$\mathrm{SO}_{2}$ sol'ns can bo used to colloot the I from the distillation. The soI'n is thon oxidized with $\mathrm{HrO}_{2}$ and tho $I_{2}$ oxtracted wont oqual volum of $\mathrm{CCl}_{4}$. The $\mathrm{I}_{2}$ washoi out of tho organio layor 1nto $\mathrm{SO}_{2} \mathrm{sol}$ 'n and the cycle ropeatod. This $\mathrm{SO}_{2}$ proooduro is troublos omo in tho exporimont abovo booauso the ${ }^{\circ 0} \mathrm{I}_{\mathrm{n}}$ devolops a gas prossuro during tho oxtractions. 
Blewent separatod: Iodino

Parget material: Sb $(N 500 \mathrm{mg})$

Type of bbdt: 60" a partioles
Prooedure by: Narquez

Time for sep'n: $\sim 40$ min.

Equipment required: 100 distillation flasks sep funnels s cent tubes

Yield: 80\% or higher

Degree of purification: At least a faotor of $10^{4}$ from other activities presont.

Adrantages: Fast and good separation.

Prooeduro:

(1) Add target, 10 mf I' carrier, 10-15 ml of saturated tartario aold and 10-16 ml of 100 001d mro $_{3}$ to distillation apparatus.

(2) Distil and oolleot $I_{2}$ in 0.5-1 $\mathrm{N} \mathrm{NaOH}$.

(3) Aoidify with $\mathrm{H}_{2} \mathrm{SO}_{4}$ until iodine turns brown and oxidire with $\mathrm{HNO}_{2}$, ( RarO $_{2}$ in aoid'sol'n). Bxtraot with equal volume $\mathrm{CCl}_{4}$.

(4) Fash I' into NaOr sol'n.

(5) Repeat $\mathrm{HaOH}-\mathrm{CCl}_{4}$ oycles as many timos as wished. (Threo oyoles gave purity listod above.)

(6) Aoidify last $\mathrm{NaOH} 801$ 'n with $\mathrm{H}_{2} \mathrm{SO}_{4}$ and reduce with $\mathrm{SO}_{2}$ gas. Blow air through soln to expel most of ${ }^{4} \mathrm{SO}_{2}$. Add $\mathrm{xs} \mathrm{Ag}+$ and a few drops of conc. $\mathrm{HNO}_{3}$.

(7) Hoat in water bath and filtor.

(8) Plate and oount as AgI.

\section{Remarks :}

Most of the loss in this procedure comes in the distillation prooess.

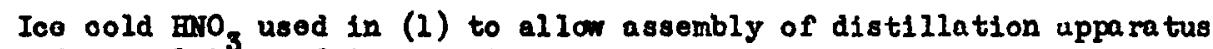
before solution of target starts.

Sol'n of Sb in aqua regia interferes with $I_{2}$ ext'n.

An $I^{-}$sample could be obtained in 15-20 min. by ppting the $A_{E_{2} I}$ direotly from the distillate of (2). The radionotive purity of the sample, however, will not be as high as above.

So, sol'n can be used to oolleot the $I_{2}$ from the distillation. The sol'n is then oxidizod with $\mathrm{HrO}_{2}$ and the $\mathrm{I}_{2}$ extracted with equal volume of $\mathrm{CCl}_{4}$. The $\mathrm{I}_{2}$ washed out of the organic layer into $\mathrm{SO}_{2} \mathrm{sol}^{2} \mathrm{n}$ and the $8 / 4 / 49$ oycle ropeatod. (See 55-1). 
Elomont scparatod: Iodino

Trrget motcrial: Ul g Bi metal

Typo of bbdt: $184^{\prime \prime}$ all partioles
Proocdure by: Goookormann

Timo for sop'n: U2 hrs.

Equipmont roquircd: Distillation flask, ocntrifugo. tubcs, 10c, $110^{\circ}$ oven.

Yield: approx. $40 \%$

Dogroo of purificotion: Decontanination factor $>10^{4}$ from fission and spallation produots.

idvantagos: Fair yicld or pure I with little if any non-cxchanec troublo.

Proocdure:

(1) Place targot in glass still, add $10 \mathrm{mg} \mathrm{\textrm {I } ^ { - }}$ and $10 \mathrm{ml} 6 \mathrm{Il} \mathrm{mrO}_{3}$, warn to dissolvo. Then ontircly dissolvod, distill over the $I_{2}$ and a $\mathrm{fCW}$ ml Hro 3 into $\mathrm{H}_{2} \mathrm{O}$ in an 100 bath.

(2) Reduoo $I_{2}$ with a minimum of $\mathrm{FaHSO}_{3}$ in the oold, adjust, to $0.5 \mathrm{H}$ $\mathrm{mnO}_{3}$, add a fer drop $0.1 \mathrm{H} \mathrm{NaFO}_{2}$, and cxtrnot $\mathrm{I}_{2}$ into an equal rolumo of $\mathrm{CCl}_{4}$. Extract aquoous with socond portion $\mathrm{CCI}_{4}$. Fash $\mathrm{CCl}_{4}$ with dilüto $\mathrm{HWO}_{3}$.

(3) Shnke CCl with $10 \mathrm{ml} \mathrm{H}_{2} \mathrm{O}$, adding $\mathrm{KaHSO}_{3}$ untIl both phasos oolorless. Fash aquedus with $\mathrm{CCl}_{\Sigma_{5}}$

(4) Repoat oxtraction oyolo soverni timos.

(5) Inke last aqueous $\mathrm{I}^{-}$solution $0.5 \mathrm{~N}$ in $\mathrm{HNO}_{3}$, hont to boiling, add $2 \mathrm{ml} 0.1 \mathrm{~N} \mathrm{AgrO}_{3}$, digost, filtor, wesh throc timos with $\mathrm{H}_{2} \mathrm{O}$, throo tims 8 with $5 \mathrm{ml}^{\circ} \mathrm{C}_{2} \mathrm{H}_{5} \mathrm{OH}$, throc timos with $5 \mathrm{ml}$ cthcr, dry $10 \mathrm{~min}$. at $110^{\circ} \mathrm{C}$. Wolgh ${ }^{2} \mathrm{AgI}^{\mathrm{T}}$ (18.50 mg por $10 \mathrm{mg} \mathrm{I}$ ).

Romarks: Lotive lodino formod as periodato may not oxohango with tho carricr by this muthod, al thourh tho I ylclds wore not abnormally low. Roduolag oondition pobnbly prevail during dissolution of the tergot. 
Element separated: Iodine

Target matorials Thorlum motal (.1-1 gin)

Type of bbdts $60^{\prime \prime} a^{2} 8$

Yie 1d: $90 \%$

Degroe of purification: $10^{6}$
Prooedure by: Newton

Time for sepin: 1 hr.

Equipmont required, standard

Prooedure: The Th motal is dissolved in cono $\mathrm{HCl}+$ a fow drops $2 \mathrm{M}$ sol in $\left(\mathrm{MH}_{4}\right)_{2} \mathrm{SiF}_{6}$ to cleer up black residue. The HCl is diluted to $2 \mathrm{II}$ and an aliquot taken.

(1) Add sample to $10 \mathrm{ml} 2 \mathrm{~K} \mathrm{Na}_{2} \mathrm{CO}_{3}$ (I) (2) Add $20 \mathrm{mg} \mathrm{I}^{-}$in $60 \mathrm{ml}$ sep fumels. Add $2 \mathrm{ml} 2.5 \%$ Hocl (2) (3eat 14 Acidify with $3 \mathrm{ml}$

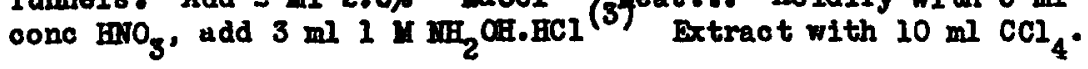

(2) Shake with $10 \mathrm{ml} \mathrm{H}_{2} \mathrm{O}$ containing a fom drops $\mathrm{MHSO}_{3}$ until both
phases colorless.

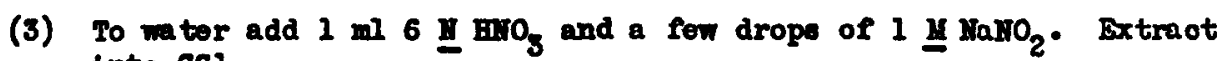
into $\operatorname{CCl}_{4}$

(4) Repent (2)

(5) Add $1 \mathrm{ml} 6 \mathrm{II} \mathrm{HrO}_{3^{\circ}}$. Heat to boiling. Add $2 \mathrm{ml} 0.1 \mathrm{II} \mathrm{AgNO}_{3} \cdot \mathrm{stir}$ and digest. Filfer on tared filtor paper. Thah throe times with $5 \mathrm{ml} \mathrm{H} 0$, throe times with $5 \mathrm{ml}$ EtOH and three times with

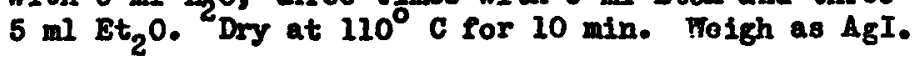

Remarks: $10 \mathrm{mg} I=18.42 \mathrm{mg}$ AgI

(1) If Bi and La presont add $1 \mathrm{ml}$ of $10 \%$ tartario aold and 19 I NaOH.

(2) Oxidize $\mathrm{I}^{-}$to $\mathrm{IO}_{4}^{-}$. Solution unst bo hoated, preforably bolled 5 minutes for complete exohange to oocur.

(3) Reduoe $\mathrm{IO}_{4}^{-}$to $\mathrm{I}_{2}$.

This mothod has been desoribed previously (Fhys. Rev. 7517 (1949)).

Preparation of carrier solution: Dissolvo 15 gms II in wator containing a traoe of labico ${ }^{\circ}$ Dilute to one liter.

Standardization: Take $5 \mathrm{ml}$ oarrier solution in beakor. Add $50 \mathrm{ml}$ $\mathrm{H}_{2} \mathrm{O}$ and $1 \mathrm{ml} 6 \mathrm{~N} \mathrm{HilO}_{3}$. Heat nearly to boiling and add $5 \mathrm{ml} 0.1 \mathrm{~N} \mathrm{HeMO}$ with stirring. Digest 1 minute. Filter into a sintered glass orucible, wash three timos rith $\mathrm{H}_{2} \mathrm{O}$, throe times with $95 \% \mathrm{EtOH}$. $\mathrm{D}_{\mathrm{H}}$ at $110^{\circ} \mathrm{C}$ and woigh as AEI

$8 / 23 / 49$ 
Element seperated: Cesium

Target material: nl g Bi motal

Type of bbdt: 184" all partioles
Procedure by: Goeokermann

Time for sep'n: Several hrs.

Equipment required: Centrifuge, tubes, emall Pt dish, 100, $110^{\circ}$ oven

Yield: Cs $\cap 40 \%$

Degree of purification: Cs had impurity whioh was probably Rb.

Advantages: Supposed to give Cs pure of all elements \& separate it from Rb. Procedure:

(1) To aliguot of $\mathrm{HrO}_{3}$ soln of target, add $20 \mathrm{mg} \mathrm{Rb}$ \& $\mathrm{Cs} 5 \mathrm{ml}$ conc. HC10 4 Evap. to Iuming, cool, transfer to cent tube with $15 \mathrm{ml}$ absolute EtOE. COOl in ioe bath 10 min. with stirring. Wash ppt trice with $10 \mathrm{ml}$ absolute EtOH.

(2) Dissolve in dilute HCl \& soav with $\mathrm{Te}, \mathrm{Ru}, \mathrm{Sn}, \mathrm{Sb}$, \& Ag sulfides (2 $\mathrm{mg}$ each) by adding $\mathrm{H}_{2} \mathrm{~S}$.

(3) Scav with $\mathrm{NH}_{3}$ pptn of $\mathrm{La}, \mathrm{Ce}, \mathrm{Y}, \mathrm{Zr}$, \& Cb (2 me oach).

(4) Scav with $\mathrm{Sr} \& \mathrm{Ba}$ carbonatos (4 mig)

(5) Aoidify with $\mathrm{HCl}$, repeat (2).

(6) Ropeat (3).

(7) Soav with $\mathrm{La}(\mathrm{OH})_{3}$.

(8) Scav with Sr \& Be sarbonates \& Y, Zr, \& Cb hydroxides.

(9) Aoidify with $\mathrm{HCl}$, evap to dryness in a Pt dish, destroy $\mathrm{NH}_{4} \mathrm{Cl}$ by adding a few drops $\mathrm{HHO}_{3}$ and baking carefully (do not overheat or Cs may be los $t$ ).

(10) Dissolvo in a minimum of $\mathrm{H}_{2} \mathrm{O}$, transfer to a cono a oent out any residue, evap to drymess in the oone. Add $6 \mathrm{ml} \mathrm{H}_{2} \mathrm{PtCl}_{6}$ \& $6 \mathrm{ml}$ EtOH, Fash $\mathrm{Rb}$ Cs ohloroplatinatos with DtOH.

(11) Dissolve in ECl \& repeat To sulfide scavenging.

(12) Repeat $\mathrm{NH}_{3}$ pptn of Ia \& Fe hydroxides.

(13) Repeat Sr \& Ba carbonate scav.

(14) Aoldify with $\mathrm{HNO}_{3}$, add HCl, evap to drymess, bake off ammonium sal ts carefully again.

(15) Cs - Thke up residue in $20 \mathrm{ml} 6 \mathrm{I} \mathrm{HCl,} \mathrm{add} 1 \mathrm{ml}$ silicotungstic aoid $P=18-65$ soln \& digest. (Save this supa. for Rb fraction). 
Wash twioe with $5 \mathrm{ml} 6 \mathrm{H} \mathrm{HCl}$ (aiscard). Dissolve Cs silicotungstate in dil $1 \mathrm{MOH}$, add $20 \mathrm{ml} 6 \mathrm{~N} \mathrm{ECl} \mathrm{at} \mathrm{discard} \mathrm{yollow} \mathrm{ppt.}$ Add 1 ml siliootungstio aoid soln, digest, filter, wash with $6 \mathrm{I} \mathrm{HCl,} \mathrm{three} \mathrm{times} \mathrm{with} 5 \mathrm{ml}$ acetone, dxy $10 \mathrm{~min}$ at $110^{\circ} \mathrm{C}$. We igh as $\mathrm{Cs}_{8} \mathrm{SiF}_{2} \mathrm{O}_{42}$ ( $37.3 \mathrm{mg}$ per $10 \mathrm{mg} \mathrm{C8}$ ) -. standardize the Cs oarrier Solution by the same prooedure.

Remarks: Noyes \& Bray reoommend ppting the Rb away from the Cs with sodium 6-chloro-5-nitrotoluenemetasulfonato, which we now have on hand, \& then ppting the Cs siliootungstate. This may give better Cs-Rb separation. It my be bettcr to weigh the Cs as Cs, PtCl after purification is complete. It has been alleged that $2 B_{1}^{2} I_{3} \cdot 36_{8} I$ pptn is specifio for Cs. I tried the pptn of $\mathrm{Rb}$ away from $\mathrm{Cs}_{\mathrm{i}} \mathrm{ith} \mathrm{th}^{3}$ cold sat. sodium bitartrate

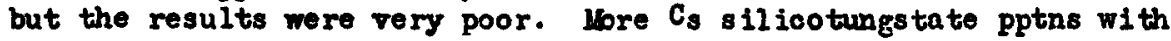
Rb holdback present would probably givo olean Cs.

The fuming of $\mathrm{HClO}_{4}$ can be done easily in $40 \mathrm{ml}$ pointed centrifuge cones.

For Rb sep'n from same target see (37-1). 


\section{CHEMICAL SEPARATIONS}

Elomont soparated: Cosium

Target materia l: $\mathrm{NH}_{4} \mathrm{I}$

Typo of bbdt: 60 llov a-particlos for one to four hours.
Proocduro by: R. W. Fink,

D. G. Karraker

Timo for sop'n: 45 minutos

Equipmont roquired: poroclain dishos pipettes coit rifugo

Yicld: $\operatorname{nin} 40 \%$

Derroc of purifioation: Exocllont, factor of $\sim \cdot 10^{6}$ from activity prosent excopt alkali motals.

Advantages: Good radiopurity althourh yiold is low due to $\mathrm{CsCl}$ volatility in stop (2).

Prooodur: :

(1) $\mathrm{NH}_{4}$ I target dissolved in smll volume ( $\mathrm{n} 3 \mathrm{cc}$ ) $(1: 1) \mathrm{HCl}$, a few dróps conc. HNO 3 added, and 20 mg of Cs onrrior addod. Soln is boilod in porcolain dish to oxpoll volatilo radioxonons, ctc.

(2) Rosidue, aftor orap. to dryness, is ignitod to disappcarance of $I_{2}$ and ammonium salts, but not hot onough to volatilizo oxcossivo cริ.

(3) Tho rosiduc is thon takon up in (1:1) $\mathrm{HrO}_{3}$, a drop of $(1: 1)$ HCl addod and pptd thrioe with a fow drops $0.1-\mathrm{N}$ AgNO $_{3}$ to soavange for any romining halogon (lodino) impuritios,

(4) To the romaining soln is addod a fow drops To carric and then oxocss $\mathrm{SnCl}_{2}$. This ppts To and any radiotollurium. (In omitting the tcllurium step, no change was noted, indicating the was not formed.)

(5) The remaining soln is mado alkoline with conc. $\mathrm{HH}_{4} \mathrm{OH}$ and $\mathrm{FoCl}_{3}$ soln added dropwiso to ppt $\mathrm{Fe}(\mathrm{OH})_{3}$ twico.

(6) The fiml soln contains radiooosium in pure form.

Romarks :

(a) Any alkall metel, e.B., Na, K, Rb, will not be separated, but will appear with the final cesium soln.

(b) Step (2) results in a loss of over 50\% of the Cs by volntilization, if the tomp. is too high. The minimum tomp. consistent vi th dccomposing and oxpelling anmonium salts should bo used. If $\mathrm{H}_{2} \mathrm{SO}_{4}$ is usod in plaos of $\mathrm{HCl}$, tho volatility will bo reduocd oonsidorably. 


\section{CHEHICAL SEPARATIONS}

Elomont soparated: Cesium

Targot matorial: $\mathrm{MH}_{4} \mathrm{I}$

Typo of bbdt: $60 \mathrm{kgv}$ a-particlos for ono to four hours
Prooodure by: R. W. Fink

Timo for sop'n: 30 minutes

Equipmont roquirod: Iodino Sublimator

Yiold: $>95 \%$

Dogree of purifioation: Factor of at lcast 5 or 10.Good onough for mass spootrograph work.

Adrantagos: Full yicld of carricr-troc radiocosium for mass spoctrograph work.

Proocdure: Speoial method for carrier-froo, high activity samples for tho mas spectrograph.

(1) $\mathrm{NH}_{4}$ I tareot is placed in a sublimator togothor $w_{2}$ th a fow drops 0.3 - $\mathrm{N} \mathrm{H}_{2} \mathrm{SO}_{1}$ and conc. $\mathrm{EHO}_{3} \cdot \mathrm{CO}_{2}$ snow is packod into tho coldfingor, and a low vacuum is pullod. Hcat is thon appliod to the $\mathrm{NH}_{4} \mathrm{I}$, which docomposos and oondonsos on tho cold-fingor.

(2) The liquid is boilod until colorless, indioating complcto volatilization of $I_{2}$ and docomposition of $\mathrm{NH}_{4} I_{\text {. The Tcmaining liquid is }}$ almost pure in cesium, but if dosired it can bo put through furthe. purifiontion, starting with stop (3) of (55-2).

a
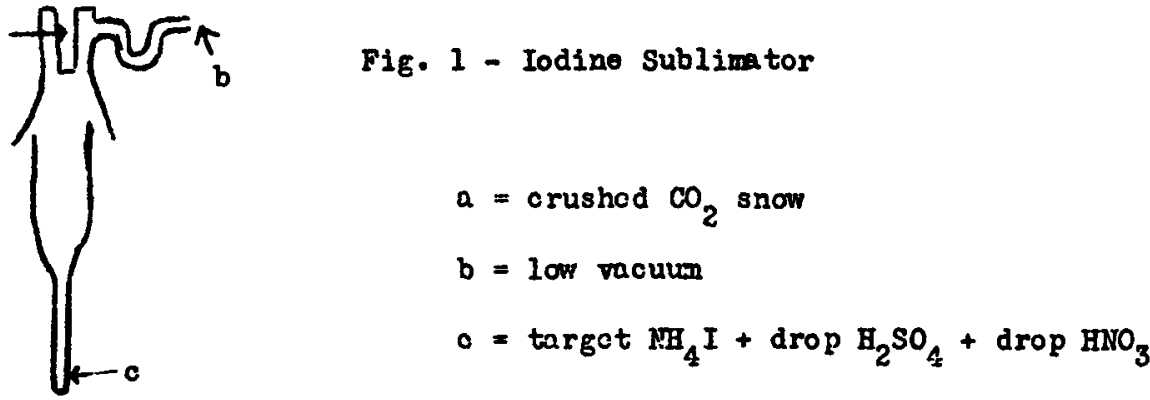

Romarks:

(a) Any alkali motal, O.g., Na., K, Rb will appoar with tho Cs.

(b) For mass speotrograph work, tho sol'n is usod as it oomos from tho sublimator di reotly. 


\section{CHERICAL SEPARA TIOAS}

Bloment separated: Cesium

Procedure by: Folger \& Hicks

Target material: $4_{\mathrm{g}} \mathrm{U}$ motal foil

Tims for sep'n: Several hrs.

Type of bbdt: $184^{\prime \prime}$ all high oner py partioles Equipment roquired: Centrifuge, tubes, 10e, $110^{\circ}$ oven

\section{Yiold: Csm6o\%}

Degrea of purifioation: Small ant of somo impurity detootod by moans of Al abs. Decay ourve shows puro Cs for $n 3$ half-lives.

Advantages: Supposed to give $C_{6}$ pure of all clements separato it from Rb.

Prooodure:

(1) To aliquot of $\mathrm{HrO}_{3}$ soln of target, add $20 \mathrm{mg} \mathrm{Rb} \& \mathrm{Cs} \& 5 \mathrm{ml}$ conc. Ec10. Evap. to Irming, cool, transfer to cont tube with $15 \mathrm{ml}$ absolute BtOH. CoOl in 100 bath 10 min. with stirring. $\mathrm{Hash}_{\mathrm{ash}}$ ppt trice with $10 \mathrm{ml}$ absolute Etor.

(2) Dissolve in $0.2 \mathrm{H} \mathrm{HCl} \mathrm{\&} \mathrm{scar} \mathrm{with} \mathrm{AgCl,} \mathrm{then} \mathrm{To,} \mathrm{Ru,} \mathrm{Sn,} \mathrm{Sb,} \mathrm{\&}$ $\mathrm{Ag}$ sulfides (2 m oach) by adding $\mathrm{H}_{2} \mathrm{~S}$.

(3) Scar with NaOH pptn of $L a, C e, Y, F C, Z r, \& C b$ (2 me each).

(4) Soav with Sr \& Ba carbonates (4 mg)

(5) Aoidify with $\mathrm{ECl}$, ropeat (2), (3) and (4).

(6) Repeat (3) and (4).

(7) Add HClO, and evap to fuming. Transfor to cent. cone with $15 \mathrm{ml}$ abs. Etof. Cool in 100 bath $10 \mathrm{~min}$. with stirring. Pash ppt. with $10 \mathrm{ml}$ abs. EtOH.

(8) Repeat (2), (3) and (4).

(9) Repoat (7).

(10) $\mathrm{Cs}$ - Take up residuo in $10 \mathrm{ml} 6 \mathrm{~N} \mathrm{HCl,} \mathrm{add} 1 \mathrm{ml}$ siliootungstio acid soln \& digcst hot. (Savo this supn. for Rb fraction). Chill and contrifuge.

(11) Fash twice with $5 \mathrm{ml} 6 \mathrm{~N} \mathrm{HCl} \mathrm{(discard).} \mathrm{Dissolvo} \mathrm{Cs} \mathrm{silicotung-}$ stato in dil. NaOH, add $10 \mathrm{ml} 6 \mathrm{~N} \mathrm{HCl}$ \& di soard yollow ppt. $\left(\mathrm{FO}_{3}\right)$.

(12) Repuat (10) with Rb holdbook. Thash \& dissolve as in (11). 
(13) Add $1 \mathrm{ml}$ sillcotungstic acid soln, digest, filter, wagh with 6 I HCl, thrce timos with $5 \mathrm{ml}$ acotono, dry $10 \mathrm{~min}$ at $110^{\circ} \mathrm{c}$. Te1 $\bar{h}$ as $\mathrm{Cs}_{8} \mathrm{SiW}_{12} \mathrm{O}_{42}$ ( $37.3 \mathrm{mg}$ per $10 \mathrm{mg} \mathrm{C}_{8}$ ) -- standardizo the $\mathrm{Cs}^{\circ}$ carrior solution by the sams proceduro.

Remarks :

(1) $\sec (55-1)$

(2) The above procoduro is for uso when Ih is desired from the same aliquot. If rubidium is not desirod, replace step (7) by stop (10) Including $\mathrm{gb}$ holdback. Step (8) should bo Included, but step (9) may be omittod.

Steps (10) through (13) should then follow in rogular soquence, with $\mathrm{Rb}$ holdback being used in (10).

(3) If it is desirod to count a weighed sample, Cs should bo weighod as $\mathrm{CB}_{2} \mathrm{PtCl}$ instond of $\mathrm{Cs}_{8} \mathrm{StD}_{12} \mathrm{O}_{42}$ in ordor to reduoo solf-absorption counting oorreotions. In ${ }^{2}$ ition a oase add to the abovo prooodures

(14) Dissolvo ppt in minimum amt. I N HoOH with warming. Noutralize koepine volume low. Add 400 HF PtCl and 400 EtOH. Digest in 3 min. with strring in an 100 bath, then lot stand 5 min. in 100 .

(15) Centrifugo and wash w. 600 abs, EtoH.

(16) Filter, wash w. 5 o0 abs. EtoH, dry in $110^{\circ} \mathrm{C}$ oron for 5 min. Vaigh as $\mathrm{Cs}_{2} \mathrm{PtCl}_{6}$. 
Eloment soparatod: Cesium

Targot matorin1: Thorium motal (.1-1 gm)

Typo of bbdt: $60^{\prime \prime} a^{\prime} s$

Y101d: $\sim 80 \%$

Dogroo of purifioation: $10^{6}$ oxoopt from fib

Prooodure:

Tho Th motal is dis solrod in oono HCl + a fCw drops of .2 1 sol'n $\left(\mathrm{NH}_{4}\right)_{2} \mathrm{SiF}_{6}$ to oloar up black roaiduo. The HCl is diluted to $2 \mathrm{I}$ and an aliquot takon.

(1) In $50 \mathrm{ml}$ beaker + sample add $20 \mathrm{mb} \mathrm{Cs}, 5 \mathrm{ml} \mathrm{FElO}_{4}$ and evaporate to fuming. Cool and transfor to contri fuge tube wi th $15 \mathrm{ml}$ absolute EtOH. Cool in 100 beth $10 \mathrm{~min}$. and centrifuge. Wash ppt tro times with $10 \mathrm{ml}$ absolute BtOF.

(2) Dissolve in $10 \mathrm{ml} \mathrm{H}_{2} \mathrm{O}$. Add $5 \mathrm{mg}$ Fe and ppt hot with $\mathrm{MH}_{4} \mathrm{OH}$. Repeat.

(3) (Optional) Add drop sat. $\left(\mathrm{MH}_{4}\right)_{2} \mathrm{CO}_{3}$ and 5 mg each Ba and Sr. Ppt Ba and Sr oarbonates. Contrifugo.

(4) Evaporate supermate to aryness in beaker, flame to decompose $\mathrm{NH}_{4}$ salts. Dissolve in a fow $\mathrm{mls}$ hot $\mathrm{H}_{2} \mathrm{O}$, add $4 \mathrm{ml} \mathrm{HClO}_{4}$, evap to 4 fumes. Reppt as $\mathrm{CsClO}_{4}$.

(5) Centrifuge and wash ppt onoe with absoluto stoH by deoantation. Slursy ppt with BtOl and filter. Ma-h with EtOH. Dry 10 min. at $110^{\circ} \mathrm{C}$. Teich as $\mathrm{CsClO}_{4}$.

Remarks: This we thod has been previously desoribed (Fhys, Rov. 75, 17 (1949). water.

Preparation of oarrior solution: Disenlvo $12.7 \mathrm{gme} \mathrm{CsCl}$ in 1 liter of

Standardigation: Take $5 \mathrm{ml}$ oarrier. Add $3 \mathrm{ml} 70 \% \mathrm{HClO}$. Fvaporato to dense fumes of $\mathrm{HC} 10$. COOI in an 100 bath and add $10 \mathrm{ml}$ bbsolute EtoH. Cool and stir occasionally for 15 minutes. Fiter onto a sinterod glasa orucible. Use 5-5 ml portlons of abs BtOH to transfer and wash. Dry 10 minutes at $110^{\circ} \mathrm{C}$. $5 \mathrm{gigh}$ as $\mathrm{C}_{8} \mathrm{ClO}_{4}$.

$8 / 19 / 49$

P-18-212 
Element separated: Barium

Target material: 0 or Th or B1

Typo of bbdt: Fission

Yield: n 100\%

Degree of purification: exoellent

Adrantages: Past and easy

Procedure:

(1) Take allquot of $\mathrm{HWO}_{3}$ or $\mathrm{HCl} s 0$ ' $^{\prime} \mathrm{n}$ of target and add Ba carrier. If neoessary evaporate to 1088 than $1 \mathrm{co}$. With tube in 100 bath, add 10 oc ether -- HCl reagent (ether-HCl roagent - $400 \mathrm{cc}$ oono. $\mathrm{HCl}+80$ o0 diethyl-ether). Stir and digest 2 or 3 minutes to bring down silks appearing $\mathrm{BaCl}_{2} \cdot 2 \mathrm{H}_{2} \mathrm{O}$.

(2) Centrifuge, dissolve in $0.5 \mathrm{cc} \mathrm{H}_{2} \mathrm{O}$, repeat (1).

(3) Contrifuge, dissolve in $0.500 \mathrm{H}_{2} \mathrm{O}$, dilute to 7-8 00, ake to $\mathrm{pH}>10$ with carbonate free ammonie and scavenge trioe with $\mathrm{Fo}(\mathrm{OB})_{3}$.

(4) ppt. $\mathrm{BaCO}_{3}$ by adding 3 drops sat $\mathrm{Na}_{2} \mathrm{CO}_{3}$, and digest 5 min. in hot water bath.

(5) Dissolve $\mathrm{BaCO}_{3}$ in $1006 \mathrm{I} \mathrm{HCL}$, repeat (1) and (2).

(6) Centrifuge, wash with 5 oc absolute alcohol, then 3 portions of 5 co ether, wolgh as $\mathrm{BaCl}_{2} \cdot 2 \mathrm{H}_{2} \mathrm{O}$.

Remarks: (2) can be modified by adding double volume of ether saturated with $\mathrm{HCl}$ cas to $\mathrm{BaCl}_{2} \cdot 2 \mathrm{H}_{2} \mathrm{O}$ dissolved in $\mathrm{H}_{2} \mathrm{O}$ and continuins to introduce HCl Eas until the ppt appears and the aqueous and organic layers become misoible.

\section{$6 / 25 / 49$}

P-18-9 


\section{CHEIICAL SBPARATIOUS}

Flement separated: Barium

Targot matorial: $n$ l B BI motal

Procedure by: Goockermann

Type of bbdt: 184" all partioles

Timo for sep'n: 1-2 hrs.

Equipment required: Contrifuge, tubes, ioe, vaouum dessicator.

\section{Y101d: $\sim 80 \%$}

Degree of purifications Deoontaminatign factor $\backsim 10^{4}$ from fission \& spallation produots. Ba decontaminated $\sim 10^{4}$ from $S r$.

Advantages: Good yleld of Ba \& Sr, soparation from all other elements exoept Ba, very good separation of $3 r$ \& Ba from each other.

Procedure:

(1) To aliquot of $\mathrm{HNO}_{3}$ soln of target, add $10 \mathrm{mg} \mathrm{Sr} \& \mathrm{Ba}, 30 \mathrm{ml}$ fuming $\mathrm{HMO}_{3}$, digest oold $1-2$ min.

(2) Dissolve ppt in $2 \mathrm{ml} \mathrm{H}_{2} \mathrm{O}$ \& reppt with $15 \mathrm{ml}$ fuming $\mathrm{HNO}_{3}$.

(3) Dissolve ppt in 5-10 $\mathrm{ml} \mathrm{H}_{2} \mathrm{O}$, add $5 \mathrm{mg} \mathrm{Fe}^{+3}$, \& ppt $\mathrm{Fe}(\mathrm{OH})_{3}$ with tank $\mathrm{NH}_{3}\left(\mathrm{CO}_{3}\right.$ froel) Repeat $\mathrm{Fe}(\mathrm{OH})_{3}$ scar.

(4) Neutralize supn with 6 II HO 3 , add $1 \mathrm{ml} 6$ II HAO \& $2 \mathrm{ml} 6$ HI MHAO. Heat to bolling \& add $1 \mathrm{ml} 1.5 \mathrm{ii} \mathrm{Ma}_{2} \mathrm{CrO}$ dropmise with stir rine. Digest ono min. (Savo tho oupn for Sr fraotion).

(5) $\mathrm{Ba}$ - "iash BaCrO 4 ppt with $10 \mathrm{ml}$ hot $\mathrm{H}_{2} \mathrm{O}$. D1 ssolvo in $1 \mathrm{ml} 6 \mathrm{~N} \mathrm{HCl}$, add few $\mathrm{mg} \mathrm{Sr}$, \& roppt BaCrO, Redissolve, add $15 \mathrm{ml}$ ether-HCl rearent (5 parts cono. BCl to 1 part di-ethyl other), digest cold 2 min, wash with $5 \mathrm{ml}$ absolute BtOH oontaining a fow drops of HCI.

Dissolve $\mathrm{BaCl}_{2}$ in $1 \mathrm{ml} \mathrm{H}_{2} \mathrm{O}$, make fust basio with $\mathrm{NH}_{3}$ \& Boav with

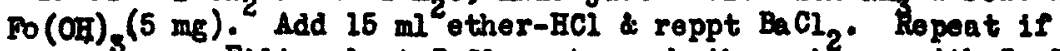
necessury. Filter last BaCl, ppt, wash three timos with 5 ml other, dry in vaouum dessicator - 2 min. ovac. release, 5 min. erac. Weigh as $\mathrm{BaCl}_{2} \cdot 2 \mathrm{H}_{2} \mathrm{O}(17.8 \mathrm{mg}$ per $10 \mathrm{mg} \mathrm{Ba})$.

Remarks: Procedure adapted for use when Sr aotivi ty mach greater than Ba.

$\mathrm{Ra}$ follows the Ba woll, can be separated from it by ues of a resin column.

For Sr sep'n from samo target sce 38-1.

$7 / 12 / 49$ 


\section{GHEICAL SMPALATIONS}

Elemont separated: Barium

Target material: CsCl

Type of bbdt: 85 Mer Protons for 1 hour
Procodure by: R. T. Fink

Time for sep'n: $90 \mathrm{~min}$.

Equipment requirod: Standard

Yiold: Sufficient for mss spoctrograph work.

Degree of purification: Cosium is persistont, but may bo romovod in suocessivo reoycilings. Purc onough for mass spectrograph work.

Advantagos :

Carrier freo Ba for mass spectrograph.

Procodure:

(1) Target $\mathrm{CsCl}$ is dissolvod in 2 oc $0.1-\mathrm{N} \mathrm{HAO,} 1 \mathrm{cc} \mathrm{NH} \mathrm{Ao}_{\text {sat'd }}$ added, and $10 \mathrm{mg}$. $\mathrm{Pb}$ carricr addod. $\mathrm{K}_{6} \mathrm{CrO}_{4}$ soln. is then addod until complete pptn. This ppt. is then washod with $1 \% \mathrm{KH}_{\mathrm{A}} \mathrm{Ac}$ until free from cosium. If nocessary, the ppt may be dissolvod in 0.1 - N HCl and ropptd. to fros it from Cs.

(2) The Cs-froo PbCrO ppt is then dissolred in $1000.1-11 \mathrm{HCl}$ and oxoess $\mathrm{H}_{2} \mathrm{~S}$ is bubblod in to ppt black $\mathrm{PbS}$ and reduco the $\mathrm{CrO}_{4}$ to $\mathrm{CrCl}_{3}$
(green).

(3) The sol'n. from (2) containing radiobarium, is mado alkalino, aftor boiling to expcll $\mathrm{H}_{2} \mathrm{~S}$ and radioargons, and some $\mathrm{Fe}(\mathrm{Cl})_{3}$ addod to holp ppt. $\mathrm{Cr}(\mathrm{OH})_{3}$.

(4) The final, colorless soln, has carrior-froe barium. It is convorted to the sulfate for mass spec. work.

Remarks :

The cosiura, being the target matorial, is vory porsistent, and soveral pptns. in stop (1) may be noedod to froo the barium of it. 
Elomont soparatod: Barium

Targot matorial: Au foll, about 18

Typo of bbdt: Full energy protons, helium 10ns, or deuterono
Prooeduro by: Lippmann \& Coockermann

Time for sop'n: $1 \mathrm{hr}$. for barium.

Equipmont required: Ioo bath and hot wator bath.

\section{Yicld: $25 \%$}

Degreo of puriflcation: Good - about $10^{5}$ from Au and spallation produots and at least $10^{3}$ from fission products.

Advantagos: $\mathrm{Sr}$, Ba and $\mathrm{Mo}$ can all bo soparatod from tho samo target material.

Procedure: Dissolve targot in hot solution contalning $10 \mathrm{mg}$ osch of $\mathrm{Sr}$, $\mathrm{Ba}$, and lio, $5 \mathrm{ml}$ of $\mathrm{IC} \mathrm{LHCl}$ and $5 \mathrm{ml}$ of fuming HNO $\mathrm{H}$. Cool solution in 100 bath and 510 ly add about $30 \mathrm{ml}$ fuming $\mathrm{HrO}_{3}{ }^{\circ} \mathrm{Sr}\left(\mathrm{HO}_{3}\right)_{2}$ and $\mathrm{Ba}\left(\mathrm{HO}_{3}\right)_{2}$ prooipitato. Contrifuge.

Dissolvo procipitato in $5 \mathrm{ml} \mathrm{H} 0$, add $5 \mathrm{mg}$ Po III, wam in hot wator bath, and prgeipitate $\mathrm{Fo}(\mathrm{OH})_{3}$ with $6 \mathrm{u} \mathrm{mB} \mathrm{OH}$. Cott rifuge. If dosirod add more Fo III and oontrifugo out $\mathrm{FoT}(\mathrm{OA})_{3}^{4}$ again. Heutralize supornatont with a fow drops of $6 \mathrm{M} \mathrm{HC} \mathrm{H}_{3} \mathrm{O}_{2}$, hoat to boiling, and add $2 \mathrm{ml}$ of $1.5 \mathrm{Y} \mathrm{Na} \mathrm{CrO}_{4}$ dropwiso. Digost BaCro 4 proeipitate in hot wator bath and contrifugo.

Wash BaCro proolpitate with $10 \mathrm{ml}$ of hot $\mathrm{H}_{2} \mathrm{O}$ and oentrifugo. Dissolve BaCro in 1. inl of $6 \mathrm{H} \mathrm{HCl}$ with heating, add $10^{2} \mathrm{mg} \mathrm{Sr}$ oarrier, 2 ml $6 \mathrm{H}$ $\mathrm{NH}_{4} \mathrm{C}_{2} \mathrm{H}_{3} \mathrm{O}_{2}, 1 \mathrm{ml} 6 \overline{\mathrm{I}} \mathrm{HC}_{2} \mathrm{H}_{3} \mathrm{O}_{2}$, heat to boiling, add $2 \mathrm{ml} 1.5 \mathrm{y} \mathrm{Ma}_{2} \mathrm{CrO}_{4}$ dropwiso" digest in hot wator bath, and oentrifuge. Dissolvo Bicro in $1 \mathrm{ml} 6 \mathrm{M} \mathrm{HCl}$ with hoating, add $15 \mathrm{ml}$ ECl-othor reagent (5 volums of $12 \mathrm{KHCI}$ plus 1 volum of ether), 0001 in 100 bath until BCI, preqipitatos, and contrifugo, $\mathrm{Dis80}$ ivo $\mathrm{BaCl}_{2}$ in $5 \mathrm{ml} \mathrm{H}_{2} \mathrm{O}$, add $5^{2} \mathrm{mg}$

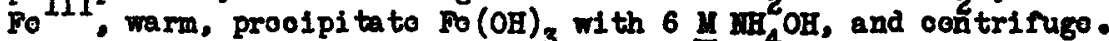

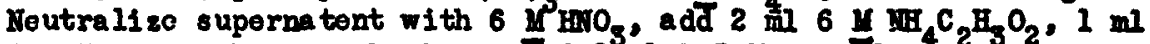
$6 \mathrm{H} \mathrm{HC}_{2} \mathrm{H}_{3} \mathrm{O}_{2}$, hoat to bolling, add $2 \mathrm{ml} 1.5 \mathrm{M} \mathrm{Na} \mathrm{CFO}_{4}$ drônise, digost

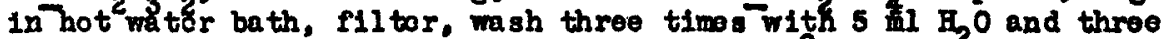
times with $6 \mathrm{ml}$ aloohol, dry 16 minutos at $110^{\circ} \mathrm{C}$. Folgh as $\mathrm{BaCrO}_{4}$.

Romariks :

All additions of fuming or oonoentrated $\mathrm{ENO}_{3}$ should bo mado cautiously: they tond to react violontly after a short induotion poriod. 


\section{CHEMCALL SERARATIOAS}

Elemont oopa rated: Bariven

Target materiali N 3 : 0 motal

Type of bbdt: 184" high opergy partioles
Procedure by: Folger

Tim for sepinz $\sim 1-11 / 2 \mathrm{hr}$.

Equipment required: Centrifuge, cones (50 ml-2 $\mathrm{gl}), 100$ bath.

Yiold: 50-75\%

Degree of purification: $N 10^{3}$ from other elements - sufficient for mass spootrograph or ion exchange oolumn.

Adrantages: Gives good yield of Ba-B with only $\sim 75$ ps carrior.

Procedure:

(1) Dissolve target in small amount cono. Hiro (heat if neqgssary). Add $100 \mathrm{pg} \mathrm{Ba}$ (as Ba $\left(\mathrm{HO}_{3}\right)_{2}$ carrier $\left.80 \mathrm{l}^{\prime} \mathrm{n}\right)^{3}$ and $20 \mathrm{mg} \mathrm{Sr}{ }^{+2}$ oarrior (as ni trate).

(2) Add funing Exro to make up $N 25 \mathrm{ml}$ and ohill in 100 bath for 10 minutes. Cobtrifugo out $\mathrm{Sr}\left(\mathrm{HO}_{3}\right)_{2}$ (Carries $\mathrm{Ba} \& \mathrm{Ba}$ ).

(3) Dissolvo in $\mathrm{H}_{2} \mathrm{O}$, transfor to $16 \mathrm{ml}$ oone and buffer with HAO +

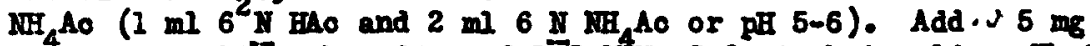
$\mathrm{Pb}^{4}$ and ppt $\mathrm{PbCrOO}$ by add in of $1.5 \mathrm{~A}^{4} \mathrm{Na}_{2} \mathrm{CrO}_{4}$ to hot 801 ' $\mathrm{n}$. Fash with hot HAO \& 18 il $\Delta_{0}$ buffor ( $1 \mathrm{ml}$ to $2 \mathrm{ml}$ \&s abovo) oontaining 1 drop $1.5 \mathrm{II}_{2} \mathrm{CFO}_{4}$.

(4) Dissolve ppt in hot $2 \mathrm{M} \mathrm{HCl,} \mathrm{pess} \mathrm{in} \mathrm{B} S$ to roduce $\mathrm{Cr}_{2} \mathrm{O}_{7}=$ to $\mathrm{Cr}^{+3}$ and dil to $0.2 \mathrm{H}$. ppt PbS, soavenge with fow ug Cus.

(5) Boil out $\mathrm{H}_{2} \mathrm{~S}$, wake basio 7 ith $\mathrm{IR}_{3}$ and $\mathrm{ppt} \mathrm{SrCO}_{3}$ by adding 2 mg $\mathrm{Sr}$ and a for arops 2 는 $\mathrm{Na}_{2} \mathrm{CO}_{3}$.

(6) Dissolve SrCg in 1 drop $6 \mathrm{IIHCl}$, boil out $\mathrm{CO}_{2}$, buffer with $2 / 2$

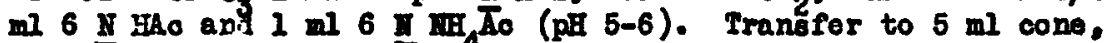
addifing not more than 1 iml H $_{2} 0$. Heat to near bolling, add minimum $\mathrm{Pb}^{+2}$ to Ppt $\mathrm{FbCrO}_{4}$ with 1 drop $1.5 \mathrm{M}_{2} \mathrm{CrO}_{4}$. Contrifuge.

(7) Dissolve $\mathrm{PbCrO}_{4}$ in 1 drop oono. $\mathrm{BCl}$. Transfor to 2 ml oone with $1 \mathrm{ml} \mathrm{ECl-ether}$ reagent. Chill $10 \mathrm{~min}$ in 100 bath and centrifuge out $\mathrm{BaCl}_{2} \cdot 2 \mathrm{H}_{2} \mathrm{O}$. Wash $\mathrm{w}$ th $1 / 2 \mathrm{ml}$ HCl-e ther reagent.

(8) Dissolvo in 1 drop $\mathrm{H}_{2} \mathrm{O}$ and add 1 drop $0.5 \mathrm{II}_{2} \mathrm{SO}_{4} \cdot$ Contrifuge out $\mathrm{BaSO}_{4}$ for masa $\mathrm{spectrograph}$.

or

(8a) Dissolto in 1 drop $H_{2} O$ and add 1 drop 0.5 NroH plus 1 drop $2 \underline{y}$ $\mathrm{Ha}_{2} \mathrm{CO}_{3}$. Centrifuge $\mathrm{ZCO}_{5}$ and dicsolvo in $0.1 \mathrm{I} \mathrm{HCl}$ for equilibration witin resin for coilumin rum. 
Remarks: If the target sol'n is obtained in large volume, buffer with $\mathrm{NH}_{4} \mathrm{AO}$ until uranium ppt's out. Contrifugo and ppt $\mathrm{PbCrO}$ from supe rmatant (20 mg or more may be required). Removo Po fy dissolving the ohromate in 1-2 N HCl, peseing in $\mathrm{H}_{2} \mathrm{~S}$, diluting to $0.2 \mathrm{~N}$ and pptin PbS. After $\mathrm{H}_{2} \mathrm{~S}$ has been bolled out, the sol'n may be made basio and $\mathrm{SrCO}_{3}$ pptid to roduce the volume. Follow with $\mathrm{Sr}\left(\mathrm{NO}_{3}\right)_{2}, \mathrm{PbCrO}_{4}$ and $\mathrm{BaCl}_{2}^{3} \cdot 2 \mathrm{H}_{2} \mathrm{O}$ ppt'ins.

For mass spootrograph work, steps 5 \& 6 may be roplaoed by:

(5-6a) Boil out $\mathrm{H}_{2} \mathrm{~S}$. Buffer to $\mathrm{pH} \mathrm{5-6}$ and $\mathrm{ppt}$ min. $\mathrm{PbCrO}_{4}$ by add in of $\mathrm{Pb}^{+2}$ and $1.5 \mathrm{Na} \mathrm{CrO}_{4}{ }^{\circ}$ Contrifuge. Mash with 2 drops $6 \mathrm{M} \mathrm{NH}_{4}^{\mathrm{AC}}$.

To remove excess alkali salts add:

(9) Fume $\mathrm{BrSO}_{4}$ to dryness to remove any $\mathrm{KH}_{4} \mathrm{Cl}$. Take up in 1 drop $0.5 \mathrm{NIH}_{2} \mathrm{SO}_{4}$. Contrifuge and rewash with 1 drop $0.5 \mathrm{II} \mathrm{H}_{2} \mathrm{SO}_{4}$.

For resin column separation of ST, $B_{Q}$, and 300 E. R. Tompkins ABCD-1998. Elute from resin with oitrate at $\mathrm{pH} 7.5-8.0$. 
CIETICiL SEPiRA TIOAS

Blement soparatod: Barium

Procodure bys Dewton

Thrget material: Thorium motal (.1-1 gm)

Tine for sopin: 45 min.

Typo of bbdt: $60^{\prime \prime}$ al phas

Bquipment requirod: standard

Yield: $90 \%$

Degroe of purifications $>10^{6}$ from all aotivities present

Proosdure: The Th motal is dissolved in oono HCl plus a fow drops of .2 1 $(\mathrm{ili})_{2} \mathrm{SIF}_{6}$ o01'n to olear up tho blnok residue. Tho HCl is diluted to 2 and an aliquot takn.

(1) $1-5 \mathrm{ml}$ sample in $50 \mathrm{ml}$ contrifuge tube. Idd $20 \mathrm{mg} \mathrm{Ba+t}$ carrier. If total volume is $>5 \mathrm{ml}$, boil dorm to $5 \mathrm{ml}$ or less. To cold solution add $30-36$ il ECl-othor roagont. St1r l-2 min whilo 0001 ing in 100 bath. Centrifugo. Tash ppt with $5 \mathrm{ml} \mathrm{BCl}-\mathrm{Bt}_{2} 0$. centrifuge.

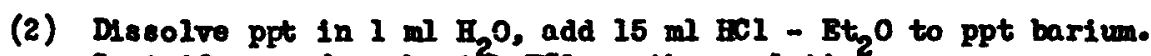
Centrifugo and wash with ECl - othor solution.

(3) Repoat (2).

(4) If soavenging is nocoseary dissolve in $4 \mathrm{al} \mathrm{H}_{2} \mathrm{O}$, add $1-2$ ms $\mathrm{Fo}^{+++}$ and frosh (oarbonate froo) IH $0 \mathrm{H}$ till an oxcoss is presont. contrifugo and discard ppt. I0 solution add $5 \mathrm{ml}$ ICl-Et, 0,0001 and contrifuge.

(5) Dissolvo ppt in $\mathrm{B}_{\mathrm{O}} \mathrm{O}$. Diluto to $10 \mathrm{ml}$, add 6 arops $\mathrm{ECl}+10 \mathrm{mg}$ h. digest, centrifuge off igCl. Ropoat.

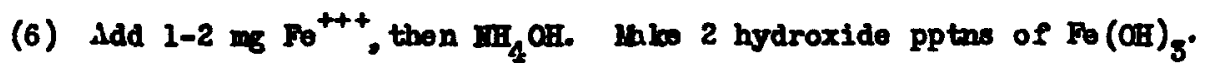

(7) Idd $\mathrm{ma}_{2} \mathrm{CO}_{3}$, ppt $\mathrm{BCO}_{5}$. Dissolve in $1 \mathrm{ml}$ cono $\mathrm{ECl}$, Ppt $\mathrm{BaCl}_{2}$ by adding BCl - EtzO rougent.

(8) Transfor ppt to weighed fliter with 3-5 ml portions of absoluto BtOH containing $4 \%$ icl. Filter with suotion. Fash three tims with $5 \mathrm{ml}$ Bt, $O$. Dry by evaovation. 2 min. evacuation, reloase, 5 min. ovaouation. Woigh as $\mathrm{BaCl}_{2} \cdot \mathrm{H}_{2} \mathrm{O}$.

Remaries: This nothod has beon dosoribod proviously. (Fhys. Bor. 7517 (1949)).

Proparation of carrier solution: Dissolvo $19.0 \mathrm{gms} \mathrm{Ba}\left(\mathrm{NO}_{3}\right)_{2}$ in wator and diluto to I IIter.

Standardization as BaCl, H $_{0}$ Tako $5 \mathrm{ml}$ carrior, add $50 \mathrm{ml}$ othor-acl mixture. Cool in 100 bath for 10 minutos. Stir. Filtor onto a sintored glass orvolblo. Doe 3 - $5 \mathrm{ml}$ portions of absoluto Btol containing 3-5 drops cono BCl to transfor and wash the ppt. Wash with three 5 wi portions of $\mathrm{Bt}_{2} \mathrm{O}$. Bvacuate and woigh as $\mathrm{BaCl}_{2} \cdot \mathrm{H}_{2} \mathrm{O}$.

$8 / 23 / 19$

P-18-285 
Elemont separatod: Barium

Target matorinl: Thorium metal (.1-1 gm)

Typo of bbdt: $60^{n}$ al phas

Yiold: $\sim 60 \%$ on $\mathrm{Ba}$

Dogroo of purificatiun; $10^{6}$ other F.P.
Prooedura by: Newton Timo for sopin: 1 hr.

Equilpment required: Standard

idvantages: Bh and $S_{r}$ oan bo takon out in same prooodure.

Procodure: Tho Th motal is dissolved in cono. HCI plus a for drops of .2 U $\left(\mathrm{NH}_{4}\right)_{2} \mathrm{SiF}_{6}$ to oloar up tho blaok rosiduo. Tho HCl is dilutod to $2 \mathrm{~N}$ and an aliquot takon.

(1) Add $20 \mathrm{mg}$ oaoh $\mathrm{Ba}$ and $\mathrm{Sr}$ carrior and $30 \mathrm{ml}$ frming nitrio acid. Cool 2-2 minutos with stirring and contrifugo. (If $\mathrm{SO}_{4}$ prosont

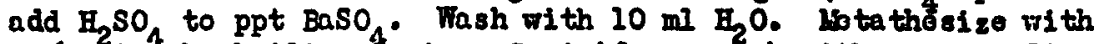
$50 \% \mathrm{I}_{5}^{2} \mathrm{CO}_{3}^{4}$ by boiling 5 min. Conterfuro, wash with wator. Dissolve ppt in $z^{3} \mathrm{HNO}_{3}$. Discard rosidue. Inen make funing nitrie aoid pptn.)

(2) Dissolve ppt in $2 \mathrm{ml} \mathrm{H}_{2}$. Ro-preoipitato it th 15 ml fuming EMO $\mathrm{H}_{3}$.

(3) Dissolvc ppt in 5 to $10 \mathrm{ml} \mathrm{H}_{2} \mathrm{O}$. Ldd $5 \mathrm{mg} \mathrm{Fo}{ }^{+++}$, ppt $\mathrm{Pe}(\mathrm{OF})_{3}$ by adding $2 \mathrm{ml}$ oarbomate froo $6^{2} \mathrm{U} \mathrm{NH}_{4} \mathrm{OH}$ or pass in $\mathrm{NH}_{3}$ gas to ppt $\mathrm{Fe}(\mathrm{OH})_{5}$. Contrifugo.

(4) Noutralizo supernate with $6 \mathrm{IIHO}$. idd $1 \mathrm{ml} 6 \mathrm{M} \mathrm{Ho,} 2 \mathrm{ml} 6 \mathrm{IH}$ $\mathrm{NH}_{4} \mathrm{LO}$. Hoat solution to noarly boiling. Add $1 \mathrm{mi}$ of $1.5 \mathrm{M} \mathrm{Na}_{2} \mathrm{CrO}_{4}$ droprisc with stirring. Let stand 1 min. Contrifuge. Roserve supernate for Sr.

(5) Wash ppt of $\mathrm{BaCrO}_{4}$ with $10 \mathrm{ml}$ hot $\mathrm{H}_{2} 0$. D18s0170 in $1-2 \mathrm{ml} 6 \mathrm{M}$ ECl add $15 \mathrm{ml} \mathrm{HCl} 1^{4}-\mathrm{Bt}_{2} \mathrm{O}$ reagont, str $1-2$ min. Contrifugo.

(6) Dissolve ppt in $1 \mathrm{ml} \mathrm{H} 0$. Reprooipitato $\mathrm{BaCl}$, with $15 \mathrm{ml} \mathrm{mCl}-\mathrm{Et}, \mathrm{O}$ reagont. Centrifugo. Tranafor ppt to wolghod filter paper with2

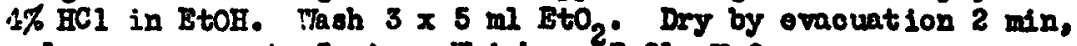
roloaso, ovaouato 5 min. Tolgh as $\mathrm{BaCl}_{2} \cdot \mathrm{H}_{2} \mathrm{O}$.

Romarko, This proooduro has boon dosoribod provious ly. (Fhys. Rov. 7617 (1949)).

For sopnration of $8 x$ from this prooodure $800(38-5)$. 
Blement separated: Lanthanum

Dargot waterial: $\mathrm{CsHO}_{3}$

Iypo of bbdt: $\mathrm{CsMO}_{3}+\mathrm{a}(25-50 \mathrm{LOV})$
Procedure by: Maumann

Time for sep'n: 1-1 1/2 hrs.

Equipment requirod: $5 \mathrm{ml}$ sep. funnels

Yield: At least $50 \%$.

Degreo of purifioation: Exoellent at least faotor of $10^{3}$ from $\mathrm{C}_{3}, \mathrm{Ba}, \mathrm{F}$, otc.

Advantages: Affords a sample froe of fluorine and containing $108 \mathrm{~s}$ than 0.1 H 8 Ia ouitable for mase speotrograph work.

\section{Procedure:}

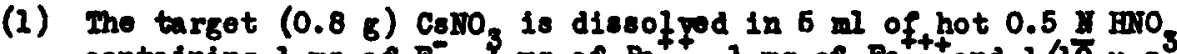
conteining $1 \mathrm{mg}$ of $\mathrm{F}^{-}$, 1 ug of $\mathrm{Ba}^{++}, 1 \mathrm{mg}$ of $\mathrm{Fe}^{+++}$and $1 / 1 \mathrm{O}^{2} \mathrm{~B}^{3}$ Lat+ (Soe (a) under remarke below.)

(2) The eolution is made basic with $\mathrm{HH}_{3}$ and the solution centrifuged.

(3) The $\mathrm{Fo}(\mathrm{OB})_{3}$ ppt is wahed three times with boiling wator redissolved in $5000.5 \mathrm{IHO}_{3}$ and $I \mathrm{mg}$ of $\mathrm{F}^{-}$and $\mathrm{Ba}^{+t}$ is added as holdback carriers.

(4) The solution is again made basio with $\mathrm{NH}_{3}$, the prooipitato oentriruged, washed and dissolved as in step (3) but only 1 as of $F$ is added, the $\mathrm{Bn}^{++}$being omitted.

(5) Fo (OH) $)_{3}$ is again preoipitated with $\mathrm{NH}_{3}$, the precipitato centrifuged and washed $3 x$ with bolling water. The precipitato is dissolved in $2 \mathrm{ml} 6 \mathrm{I}$ ECl (See (b) under remarks below.) and extraotod trioe with 2 ml ether. (See (0) undor remarks below.) The aqueous ECl solution is evaporated to $1 / 4 \mathrm{co}, 1 \mathrm{ml}$ concentrated nitrio aoid is added and the solution evaporated to about $50 \lambda$. Inis solution is placed on the filament of the mass speotrograph.

Remarks :

(a) If $\times 8 \mathrm{Ba}^{++} F^{-}$are added $\mathrm{BaF}$ will prooipitato. The $0.1 \mathrm{p} \mathrm{g}$ La serves to give a line at mass number 159 on the mass spoctrograph plate.

(b) At this point an aliquot is takon for counting, etc.

(o) Som La 18 extraotod into the ether but this apparently is una vo idablo.

(d) Rare earthe if present from bombarding a mixture of target materials would not bo separated in this procedure. 


\section{7 through 71-1}

\section{CHE:ICAI SLPABATIONS}

Eloment separated: Rare earths

Target material: Rare earth oxides

Prooedure by: Holge Hilkinson

Type of bbdt: $60^{n}$

Time for sep'n: $1 / 2 \mathrm{hr},-1 \mathrm{hr}$.

Bquipment requil rod: lus teroid tubes

Yieldi in 100\%

Degree of purifloation: $200 \%$ from all other elomonts besides rare earths thomselves.

Prooedure:

(1) Dissolve rare earth oxides in conc. $\mathrm{HNO}_{3}$, ppt hydroxides with oono. $\mathrm{NH}_{4} \mathrm{OR}$.

(2) Tash hydroxides unt11 wash is neutral. This inoreases yield markediy.

(3) Dissolvo in $\mathrm{FHO}_{3}$, transfer to lusterold, add 5 o0 cono. HP, digost in hot water bath, contrifuge, and wash fluorides with water.

(4) Dissolve $\mathrm{fl}$ uorides in $\mathrm{BrO}_{3}-\mathrm{H}_{3} \mathrm{BO}_{3}$ mixturo (8-10 $\mathrm{f} \mathrm{BNO}_{3}$ saturated with $\mathrm{B}_{3} \mathrm{BO}_{3}$ )

(5) Repeat 2-4 twioe.

(6) Dissolve final hydroxides in HCl pH $1-1.5$ and transfor to ion exchange resin colume.

$6 / 25 / 49$

P-18-11 
Exorpte from Papor on "Radioaotive Isotopes of the Rare Earths. I. Experimental Toahnique and Thulium Isotopos" - Fays Ror 15 1570 (1949) Coofr roy Hilleinson and Barry Bioks

\section{Lbstraot:}

Tho experimental teohaiquos usod in tho chomioal soparation and idontifioation of radioaotive isotopes of the raro oarth eloments aro described. The isotopes are producod by bombardment of rare earth oxidos with w-partiolos douterons, and protons from the 60-1noh Crocker laboratory oyolotron, and also by bombardmant of tantalim with $200 \mathrm{Lv}$ deuterons from tho 184-inoh oyolotron.

\section{Introduction}

Tho extrom diffloulty in achioring segaiation of the raro earth olomonts In a very puro state has been overooms in rocent yoars by tro main advanoes in exporimental toohnigues. These have mant that not only maoro, but traoor, amounts of rare earths oan be roliably soparated from oach othor in a for hours.

Wethods of soparation based on multiplo oxidation statos of the rare carth olementa havo beon dovofopod for ouropium, sawarium, and other raro earths, partioularly by lecoy and Mroh, using sino and sodium

1.H.J.16Coy, J. Am. Chom. Soc. 57, 1756 (1935): 59, 1131 (1937): 63, 3422 (1941)

2. J. R. Krsh, J. Chom. Soo. 398, 623 (1942).

amalgan reduotion prooodures, while tho separation of rare oartha by tho uso of ooluming of lon-oxohange rosins has boon dowolopod in tho lanhg ttan Projeot, and has beon desoribed in a comproheneivo sories of papers."

3. E. R. Tompkins, J. X, Thym and 7. E. Cohn, J. An. Chem. Soo. 69, 2769 (1947); F. H. Spodding ot al.. J. Am. Chom. Soo. 69, 2777, 2786, 2812

(1947); E. R. Tompkins and S. F. Hzyor, J. Am. Chom. Soc. 69, 2869, 2866 (1947).

Thoso procodures havo given a great impotus to rosoaroh on rafo sarth isotopos formod in fission of uranium and also by neutron oxpture. Iittlo

4. E. R. Tompkins, J. X. Fhym and T. E. Cohn, J. Am. Chom. Soo. 69, 2769 (1947); J. 4. Bhrinsky, L. E. Clondenin, and C. D. Coryoll, J. Am. Chom. Soo. 69. 2781 (1947); D. H. Harris and B. R. Tompldins, J. Am. Chom. Soo. 69, 2792 (1947); B. H. Kotello and G. E. Boyd, J. Am. Chom. Soo. 69, 2800 (1947); U. E. Cohn, G. W. Parkor and E. R. Tompleins, Hulconios 3,22 (1948).

work, however, has boon dono on noutron doficicnt isotopos formod by proton, doutoron, and a-partiolo bombardmont of the raro carths. A systomatio study has, theroforo, beon undertakon to remody this dofiolonoy in tho knowlodgo of suoh 1sotopes, and further, to allow intorprotation of the rosults of 
high energy particle bombardmonts of olements abovo the rero carths using the 1E4-inch cyclotron. In a provious noto," a list of now rare carth

5. G. Milkınson and H. G. Hioks, Phys, Rov. 74, 1733 (1948).

activitios and thoir propertios was given; the prosent paper desoribos the oxporimontal prjooduros usod, and the propertios of the new thulium actiritics.

\section{Exporimontal}

\section{A. Bombardmonits}

Whero oomparativoly largo quantitics of matorial woro avallabis, hundred milligram amounts of raro carth oxide wero sproad on a ridged coppor targot plato, which was then covored with 0.2 mil tantalum foil. In all othor oascs, ton to twonty milligram samples of the oxides worc bombardod on intcrooptor tarects placed in the boam of the 60-inoh Crockor Laborctory cyclotron. The finoly powdored oxide was sproad crenly on a small platinum tray with a grooved inner surface, which was silver soldorod to a wator-cooled copper holder. The exido layer was wottod, and a fow drops of diluto sodium silicato solution dropped on top of it. Aftor craporntion cnd drying under an infra-rod hoat lamp, tho oxide wes very firmly bound in an even layer. Targots 80 prepared havo withstood over a hundrod mioroampere-hours of $20 \mathrm{lfev}$ deutirons wi thout loss. Tho targets woro covorod with 0.2 mil tnntalum foil as additional protoction.

Bombsrdmonts of rare oarth oxides havo boen made with 38 Hov wparticles, $19 \mathrm{kev}$ deuterons, and $10 \mathrm{Ike}$ protons from the 60-inch Crocker Laboratory oyclotron; runs with low onorgy a-particlos were mado by placing suitablo thicknossos of tantalum foil over tho intoroeptor target. Tantalum, as tho metal foil, was bombarded with $200110 v$ douterons from the 184-inch cyclotron.

\section{B. Chomical Soparations}

After bombardmont, the raro ocrth oxide was dissolvod in nitrio aoid, and insoluble matter removed by contrifugation. Carriors for contaminating activities likcly to be formod from the targot materials -- ooppor, tantalum, platinum, sodium silioato, ete. wore added, and tho raro carth fluorido precipitated from hot 2 iN nitric aoid solution by addition of hydrofluorio acid. Tho washed fluorido was dissolved in a mixture of conoontratod nitrio acid and saturated boric acid; from this solution, tho raro oarth hydroxido was procipitated by addition of ammonium hydroxido. Tho wrshod hydroxido was dissolvod in nitric aoid and a further fluorido proolpitation mde as bofore. Throe or four such oyoles wore mado, after which, tho hydroxido was dissolved in a minimum or hydrochloric acid and tho solution accurately adjustod to a known volume. Aliquots of this solution wore taken for diroct mensuroment of radioactivitios, for ohomical separation of tho individual raro oarth olomonts, and for ostimation of the chomionl yicld of the bombardod oxido. Raro oarths wore detcrmined for chomical yield measuroment, by the prooipitation of oxalate, followed by ignition to tho oxido, and weighing.

The tantalum, after bombardment with $200 \mathrm{Mev}$ deutirons, was dissolved in the minimum of nitrio and hydrofluoric aoids. To the bolling solution ras 
addod borio acid, to complex the fluoride, followed by corium III solution 28 a oarrier for tho mre oarth aotivitios. After dilution, cxoess hydrofluorio aoid ras sddod to prooipitato corlum III fluorido. The ocrium wns purifiod by hydroxide-fluorido oyolos as abovo. To tho final solution in strong nitrio aoid was addod a small quantity of lanthnnum (o2. 0.1 mg) and the oorium oxidizod to tho IV oxidation 8 tato by addition of sodium bismuthate. The corlum was then romovod by procipitation of coriun IV phosphate from 3 In nitrio aoid solution. Tho lanthanum, with tho raro carth aotivitios, was roooverod as the fluroide, which was thon convertod to the ohloride for subsequont separations on the ion-exchango columens.

\section{Chomioal Scparation of tho Raro Barth Blomonts}

Chomical scparation of the individual raro oarth olomonts was made by ion-oxohango resin column, or for ouropium, by an amigam roduotion mothod. Tha prinoiplo of colum scparation involvos first the adsorption of tho raro carth ions in diluto acid solution on a small quantity of ioncxchango rosin. This rosin is thon ploood at tho top of a rosin oolum, through whioh is thon passed a solution of a oomploxing agont for tho raro carths, $0.8 .$. armonium citrate. The raro oarths aro oluted undor strictly controllod oonditione and pasa through tho collum at various ratos; lutooium is tho first to appoar in tho oluate, followod in succession by yttorbium, thulium, orbium, cto.

In proliminary oxperimonts to dotorminc tho olaraotoristics of column sepcrations and optimum soparation conditions for $1^{\text {the rare oarths, both }}$ inaotive rare onrths in milligram amounts, and $Y^{91}$ fedionotive usod. The former were dotorminod speotrosoopioally and tho $Y^{91}$ dotcrminod by 1 ts radioactivity.

6. Spoctrosoopio analysos of the rare oarthe wore mado in this laboratory by Ir. J. Conway and H. L. Woro, to whom wo aro greatly indebtod for thoir assistanoc. 
1. Preparption of the Column. - All column scparations were mado using Dowox-50, sn aromatic hydrobarbon polymor containing many nuc loar

7. ग. C. Bauman, Ind. Eng. Chom. 38, 46 (1946); W. C. Bauman and J. Bchhorn J. Am. Chom. Soc. 692030 (1947).

sulfonic aold groups. Tho rosin usod wis the colloidal agglomoratos, Bntoh 198914 supplied as the sodium form. The ammonium form of the resin ras propared by atirring with saturated ammonium chlorido solution; cxooss anrmonium ohlorido was remorod by mashing with water. The resin was gradod to have a scttling timo of loss than fire minutes for five oontimetors in frater at room tempercture. The longth of the proliminary resin column was $50 \mathrm{~cm}$, with 2 diamotor of $0.4 \mathrm{~cm}$, but in subsoquont runs, it was found that $20 \mathrm{~cm} \times 0.4 \mathrm{~cm}$ and $20 \mathrm{~cm} \times 1.0 \mathrm{~cm}$ columns gave ndoqun to soparation.

2. Adsorption of Raro Farths on Resin. - The raro oarth solution in

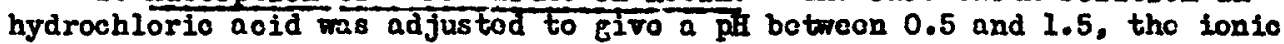
strength buinr kopt at a minimum; this solution was thon agitcicd with about $0.2 \mathrm{ml}$ of rusin addod in tro or throo guooossivc portions. The solution ond rosin vere agitatod nt about $70 \mathrm{C}$, but woro not alloncd to stand in contant for morc thon 15 minutos. This prevents diffusion of lons into the interior of the $a_{5}$ flomorates, and subscquent slor clution with poor sc parations.

3. Operation of the Column. - Tho rosin, with tho rare carth adsorbed on it, was transforrod to tho top of the resin colum, and the oluting agont passed through. Tho oluting agont usod wes a 0.25 y solution of c.P. oitric acid, nocuratcly adjustod to $\mathrm{pH} 3.05$ with s.monium hydroxido. Carc was taken to epprosch this riluo from the acid side, so thet readjustmont with aoid was not nocessary, sinoc it is importnnt for good separations to kocp the ionic strongth at a minimum. Tho flow rate ms approximatoly 0.03 milliliter por squarc centimetor column arca por minute; vith tho columns usod, of diameter $0.4 \mathrm{~cm}$, and with a drop 8120 of about $0.03 \mathrm{ml}$, this flow rato correspondod to ono drop in 3.5-4 minutes.

The eluate was collected in $10 \times 75 \mathrm{~mm}$ rimloss test tubes plnecd in a porforated turntable, which was rotatod automitioally at various time sottings, to placo succeoding tubes undor the oolum. Samplos were normally collectod for 15 minutos. In runs with aetivo materials, alliquots worc takon with mioropipettes and cvaporatod on stninless stecl disks for counting. Nliquots wCrc also takon for spootroscopio anal ysis of moro amounts of rarc carths prosent. The amount of rarc oarth, doterminod oi ther spoctrosoopianlly or by activity measurcmonts, wes thon plotted against tho samplo numbor. This allows cstimation of tho dogrec of soparation aohiovod. In .11 column runs. samplos collcetod bofore tho olution of ono "froo colum volumo" wcre disrogarded. After completion of a column run, any residual ootivity or rare cnrth wes strippod from the colum with $0.25 \mathrm{H}$ comonium oitrato of $\mathrm{pH} 7$ as cluting agont. After thoroughly washing with wator, tho column was again ready for usc.

Aftcr separation on the colum, the rare carths wors reoovorod by creporation of the citratc solution with nitrie and perohloric aoids with subscquont ignition. Tho raro carth residuo wes thon oxtracted with nitrio acid and the hydroxido prceipitatod with ammonium hydroxide. If the 
solution containod only trocor amounts, a small cmount of lanthanum was addod as a carríor.

In addition to striot control of tho conditions montionod above, it is also important for succossful separations, that the capacity of the rosin for adsorption of raro carth ions 18 not cxooodod. For the columns describod, the maximum oapaoity corresponds to approximatoly $10 \mathrm{mg}$ and 100 ing of raro oarth oxido, respootivoly. Whore tho starting materials containod aignifloant amounts of other raro corth impuritics, and purifiontion ws.s nocossary beforo bomberdmont, a larger column, which ha a capaci ty for about 18 raro oarth oxide mis usod. Tho a rea of the column and the drop rato worc scaled up from tho valuos usod in tho 0.4 on ind $1.0 \mathrm{~cm}$ dicmetor oolumn rune, the cmount of oitrato flowing through unit cross-800tioml aroa of resin being kopt oonstant. Tho progress of any perticular inactivo rarc oarth through tho column oould bo chooked by using radioactivo traoor for a neichboring heavicr raro oarth. After clution of tho notive tracor, tho sample numbers of tho dosirod inactive raro carth woro ostimatod by comparison with tho standard oiution ourvo (Fig. i). Aliquots of tho snmples woro then oxamincd spoctroscopically to allow tho puro rnro oarth fractions to be isolated.

4. Results in Column Scparations. - In Fig. 1 is shown tho "standard

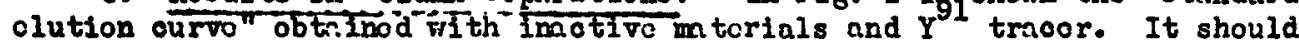
bo notod that whilc the lutocium and ytterbium aro very closo together. samplos from the pecks of these curves have no dotcotable linos of coch other or of other rare carths in their spootra. Thus samples of thoso noighboring olomonts can bo obtaincd in which tho soparation footor is at loast a thousand.

A typical column run on a bombardod samplo is shown in Fig. 2, whorc the brolon lino shows the distribution of radioactivity produced by 38 liov alpha-partic lo bombardmont of holmium oxide. Tho solid lines show the distribution of inactive carricrs of lutccium, yttcrbium, crbium, and dysprosium, addod as refcrenoos, and doterminod spectrogrnphically.

A further cxamplo of a column scperction is shown in Fig. 3 , where the rarc oarths are prosent in trocor quantitics only. In such casos, scparation is genorally clocnor and thoro is loss "toiling" of the posks, than whero macro amounts of raro onrths aro soparntod. Tho activitics shown in Fig. 3 woro spallation products, obtainod by tho bombnrdment os tentalum with 200 vov douterons from the 184-inoh cyclotron. Lonthnnum was uscd as a ccrrior for the radioisotopos. A study of the rediation cha ractoristios and docays of the poak samplos has shown no evidence of oontunination.

\section{Soparation of Duropium}

Buropium has bcen purificd prior to, and recovered after bombardmont by a modification of WeCoy's mothod. The curopium in $6 \mathrm{~N}$ hydrochloric scid solution was roduced to the divalent stato by boiling with zino amalgam. Rare oarths othor then wuropium woro procipitated by oarbonatofrco ammonia using corium as a carricr. After contrifuging, tho supornatant solution was withdrem, tho curopium oxidizcd by ozono, and thon prooipitatod by amonia. The proooduro was roponted with both fractions to onsurc oomploto soparation.

$$
8 / 16 / 49
$$

P-18-190 


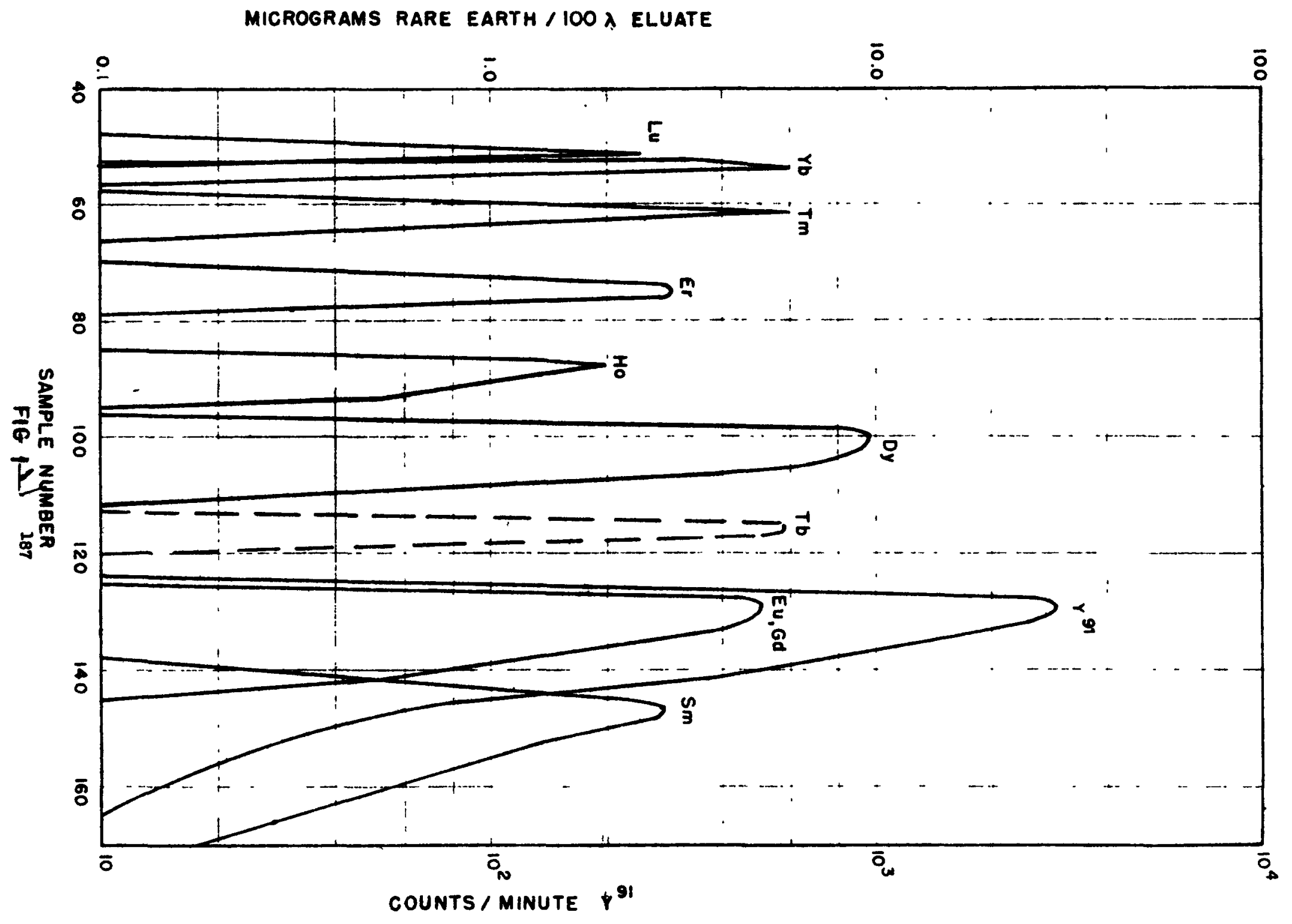




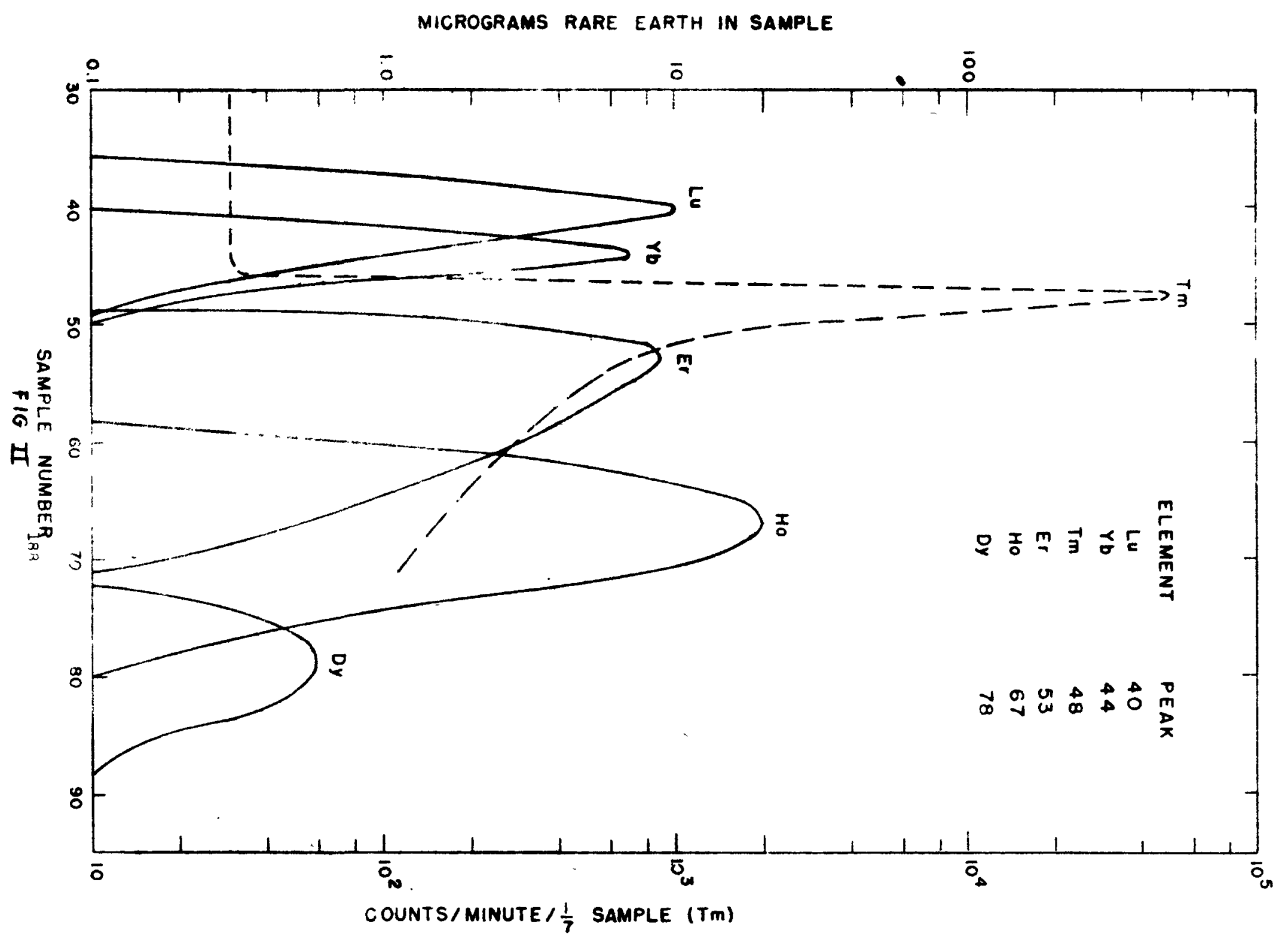




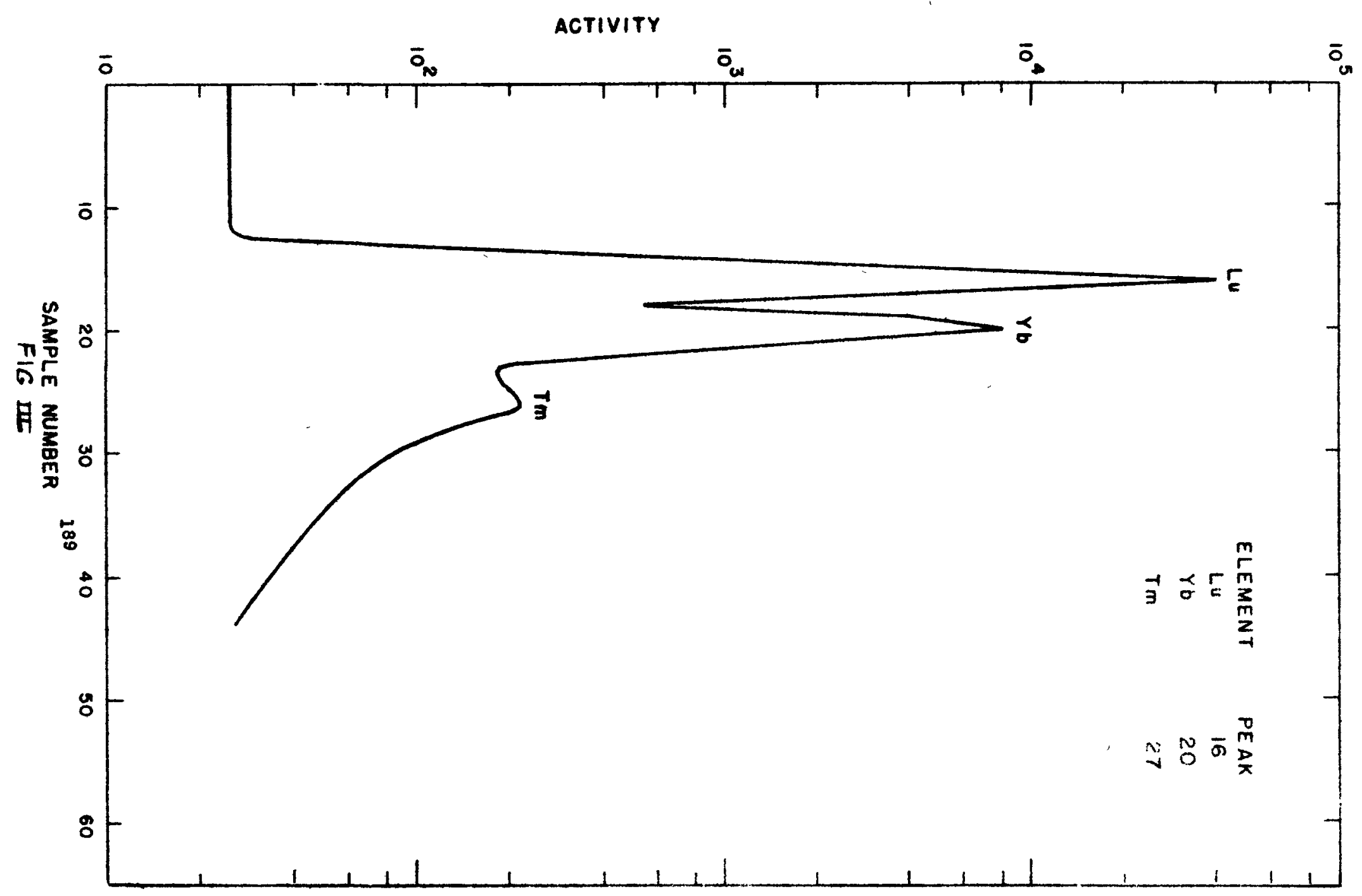


The Preparation of Grem Amounts of Spectrosoopionlly Pure Rare Earths Using Dowox 50 :

Eloments Purificd: Pr, Nd, Bu, Gd, Dy.

Sterting Whtorial: The bost matorial commorcially availablo in gram amounts. Tho starting matorial usually containod $\sim 99 \%$ of tho dosircd consti tuont.

Procoduro by: R. C. Lilly, D. C. Stcwart. Basod on original data givon in JiCS, 69, 2769-2879 (1947).

Timo for Purification: 2-3 mooks

Equipmont roquired: Lergo colum sctup (soo bolon)

nutomatio sampler

12 dosch $100 \mathrm{ml}$ oontrifugo tubos

large boakors

sol'n bottlos (12 litor sizo)

Yiold: 90\%

Dogroo of Purifieation: In tho anso of raro carths from Co through Gd, samplos can bo obtainod which contain no othor raro carth lincs. Abovo Cd, the separation is 2088 oomploto.

Advantagos: Iarge oapaity allows proparation of 5 gms of motorial in onc run.

Dosoription of Apparatus Dacd:-

A. Coluen

(1) The oolumen is construotod of Pyrux tubing, 4-6 om. 1.d. and from 60-75 on in longth. The lower ond of the tube is roundod out slightly and fittod with n piooo of oapillary tubing 3 om long, $7 \mathrm{ma} 0 . d .$, and 1 i.d. $h$ small woll is loft in the large tubo just nbovo tho start of tho oapillary to hold a glass wool plug.

(2) The uppor ond of tho oolum is oquippod with a rubbor stoppor which has boon fittod with a 5 an piooc of 10-12 mo glass tubing and hollowod out undornoath to give a domo-shspod spaco whose top is Plush with tho ond of tho glase tubing. mis typo of stoppor provonts th. 20cumilation of air at tho top of the colume.

(3) Tho glass tubo oxtonding up from the stoppor is connootod to a rosorvoir bottlo by a longth of tygon tubing. Provision is mado for raising or lowor tho resorvolr to rogulato tho flow rato.

B. Lutomatio Sampling Yohanism

(1) The usual automatio samplor, providing holos for 60 small tubos, is rovisod by substituting a luoito top diso oquippod with 30 holos largo onough for a $100 \mathrm{ml}$ contrifugo tubo. Sinos thoso samplors 
have 60 otops in ono complete rovolution, the column is sot up so that oach tube takes up two turns of the whocl and is under the columin for $1 / 30$ of a cyolo.

(2) Tho sompler is a.lso modifiod by the inclusion of a largo aluminum separator botwcon the tro discs so that the largo contrifugo tubes aro supported noar tho top and will not fall out of position.

Genoral Opcrations and Information: -

1. Properation of $\mathrm{RH}_{4}^{+}$resin.

(1) Uso 250-500 mosh Dowox 50*. Hoat throo timos at $100^{\circ} \mathrm{C}$ with $11 / 2$ volumes of $4 \mathrm{NB} \mathrm{Cl}$. Fash 8 timos with $21 / 2$ volumos of distillod $\mathrm{H}_{2} \mathrm{O}$. Aftor onch wash discard the supornatent and any fine matorial surs pondod in 1 t.

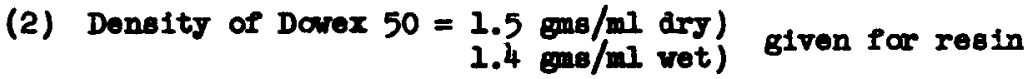

Apparent density in colum $=0.58 \mathrm{gms} / \mathrm{ml}$ dry) $0.72 \mathrm{gms} / \mathrm{ml}$ rot)

Iran experimental

results

Thus $\sim 40$ of the colven volume 18 resin.

* Also referred to as "Nalcite" and "Ionex". The effective Molecular weight 18184.

B. Proparation of Almoniun Citrate Stock Sol'n.

(1) Cambine the following:

12 gms Bakers C.P. phonol

600 gms Verck Reagont grade citric acid

116 ml Reagent grade $\mathrm{NH}_{4} \mathrm{OH}$

(2) Dilute to 12 liters with $\mathrm{H}_{2} \mathrm{O}$, mixing well.

(3) Remove a small sample and tost the acidity with a pH meter. It should be between $\mathrm{pH} 3.00$ and 3.10. If it 1s not, add $\mathrm{NH}_{4}$ OH or $\mathrm{HClO}_{4}$.

(4) Citric acid data.

Nolecular welght of monohydrate $=192$

$\mathrm{K}_{1}=8.2 \times 10^{-4} ; \mathrm{K}_{2}=1.77 \times 10^{-5} ; \mathrm{K}_{3}=3.9 \times 10^{-7}$

C. Adsorption of Raro Earthe on Dowox 50 .

(1) Dissolvo the mterial to be purifiod in the loast possiblo amount of $\mathrm{HClO}_{4}$ and dilute to $50 \mathrm{ml}$. If the sol'n doos not roman in olcar on dilution, add sovernl milliliters of cono. BCl and hont tho semplo furthor. 
(2) Transfer tho sol'n, having $\therefore$ volymg of $50 \mathrm{ml}$, to a $250 \mathrm{ml}$ glassstopporod bottlo. Add enough Bu trocge in $\mathrm{HClO}_{4}$ or $\mathrm{HCl}$ soln to givo a total of $\sim 500,000 \mathrm{c} / \mathrm{m}$ of Eshoff i of oountor. woll and pipotte out $100 \lambda$. Dry and court.

(3) Air dry somo of the rosin proparod os in (i) aborc, and woigh out $10 \mathrm{gms}$ for cr.ch gran of rire carth oxide which has boon dissolvod.

(1) Add this rosin to the sol'n from step (2). Paraffin tho bottlo and shako it mochanioally for 1-2 hours. Allow tho rasin to settle; remove $100 \lambda$ of the supornatent soln, dry, and count. Comparo with tho oount obtained in 8 top (2) to determine the poroontaro adsorbed. If it is 1 ess than $95 \%$, add more $\mathrm{HClO}_{1}$ or morc resin, or both, and sheiso again.

(5) incn the count shows cnough of the matorinl to havo boon adsorbod, draw of $f$ tho supornatant. Wash tho resin vith $50 \mathrm{ml}$ of $\mathrm{H}_{2} \mathrm{O}$ and discard tho rrosin. Than resh with $50 \mathrm{ml}$ of $\mathrm{pH} 2$ anronium oltrato soln (proparod by adding oonc BCl to somo of tho soln proparcd in (B)), and discard this wash. Tho rosin is now raady to bo slurriod onto the propared resin bod.

\section{Proosdure: -}

(1) Plc.00 a mall Pyrox glase wool plue in the woll above the oapillary tubo and wot it with $\mathrm{H}_{2} \mathrm{O}$. Add a slurry of tho rosin in $\mathrm{H}_{2} \mathrm{O}$ proparod as in ( $\Lambda$ ) aboto, fllling the tabe to a hoight of

$$
\begin{aligned}
& \sim 20 \text { om for } \mathrm{Pr} \text {, Ird } \\
& \sim 40 \text { om for } \mathrm{Sm} \text {, Eu } \\
& \text { at loast } 60 \text { om for } \mathrm{Gd} \text { and highor raro oarths. }
\end{aligned}
$$

(2) Aftor mking sure thet tho glass wool plug has not boom misplaood, allow the rosin to settlo for sovorn.l hours and form a woll-paokod bod.

(3) Transfor the "hot" resin oontaining tho adsorbod rare carth matorial as propared in $C$ above to the top of the column by slurrying it on with a small anount of $\mathrm{pH} 2$ ammonium oitrato sol'n. lake suro thet tho rosin sottlo s out in a lovol band.

(4) Carcfully fill tho column with $\mathrm{H}_{3} \mathrm{O}$ and put the rubbor stoppor in pla00 so that all of tho air bubblos a ro forood up into tho glass tube in tho middlo of the stoppor and fimaliy out through tho rosorvoir bottlo.

(5) Fill the rosorvoir bottlo with tho pH 3.05 ammonium oitrato sol'n and sllow the liquid to fill the tygon tubing londing to the column. clamp the tubing until roady for the flow to bogin. (Cautionl) Do not menipula to the tubing in suoh a way that a pnrtial vacuum is cror created at the top of the column or tho wholo resin bed will bo suckod upward, and the glass wool plug will bo dislodgod.) 
(6) After the automatic sampler has been put in place, start the flow and regulate it by raising or lowering the reservoir so that the rate is from 4-5 sec/drop $(75-90 \mathrm{ml} / \mathrm{hr})$ for $\mathrm{Pr}$ and Nd to not faster than $8 \mathrm{sec} / \mathrm{Arop}(40 \mathrm{ml} / \mathrm{hr})$ for $G d$ and higher rare earths. The rates, 40-90 ml/hr, correspond to figures of $0.033-0.075 \mathrm{ml} / \mathrm{cm}^{2}$ for a $5 \mathrm{~cm}$ i.d. column.

(7) Collect samples as desired. The progress of the rare earths throu gh the column oan be followed roughly by checking the position of the Eu tracer with a sersitive survey mer.

(8) The material being purified is best detected by removing 1-2 $\mathrm{ml}$ from each of several seleoted tubes, placing the samples in a small beaker and adding a few crystals of oxalio acid. Then weighable amounts of rare earths come through, this test will result in a turbidity or a sizeable white ppt., depending on the amount of material.

(9) Then 0.11 of the desired material has been eluted, as shown by the above test, and an additional volume has been run through as a safety factor, stop the ammonium citrate flow and the sampler.

(10) Determine the becinning and eud of the elution penli by testing as abovo. Prepare samples for spectroscopic analys is as desired, either at both ends of the peak or at regular intervals throughout its lengtr. In ench oasc pipette $50 \lambda$ of the soln onto a $\mathrm{Cu}$ speotroscope electrode and dry.

(11) On the basis of the spectroscopic anal ysis combine the tubes into fractions according to purity. In each case, transfor the solns and washings to $n$ beaker of appropriate size and boil to $\sim 1 / 3$ the volume. Add oxalio acid ( $1 \mathrm{gm}$ for each $25 \mathrm{ml}$ of soln) which hns been dissolved in $\mathrm{H}_{2} \mathrm{O}$ and hented to boiling, pouring it into the boiling sample soln and stirring well. Digest the sample over low hoat with continued stirring for ono hour. Allow the ppt to settle, preforably overnight.

(12) Draw off the supernatant and concentrate the ppt by successive centrifugings. Transfer the materinl to a Pt dish by slurrying with $\mathrm{H}_{2} \mathrm{O}$, dry it, and ignite to constant weight at $700^{\circ} \mathrm{C}$.

Remerks :

(1) In order to secure spectroscopically pure material it is important that special care be taken at all times to see that all equipment is clean and that all reagents used are from fresh containers of known purity. Since it is difficult to remore all traces of dichromate olenaing solution from glassware, the centrifuge tubes and beakers used were cleaned with aqua regia instead of cleaning soln and rinsed very thoroughly. During the run the sempler and tubes were covered with a large shield to grevent dust from droppirf into the samoles; and during subsequent steps all contriners wer kept well covered. 
(2) The rare earths, in general, are elutod in the reverse order from the ir periodio table arrangement, i.e.. Iuteolum oomes off first and lanthanum last. If the samo oluting agent is used throughout, the conoentration vo time peaks become progressively broader and further apart as the lighter rare onrths are approached. This moans that prassoodymium, for example, is rolatively easy to purify, but will be spread through a number of fraotions; whereas the heapy rare earthe are diffloult to purify and are distributod through fower tubes per poak.

(3) The Tompkins-lhyer equations (JACS 69,2859 (1947)) can be used to caloulate theoretical separation ourves. They require that the plates per oentineter be known for the resin, and that the "in values (number of free volums of elutant at the peak) be known for the Individual rare earth elements. The experimental data taken are not oomplete enough to give very acourate figures, but it is estimated that the 250-500 mesh Dowex 50 used as desoribed is equivalont to $\sim$ 15-20 plates per oentimeter of oolvem length. Som "C" values are as follows: Bu $\Xi 16$; Sm $\approx 20$; and $\operatorname{Pr} \widetilde{X} 5$. 
Elomont separatod: Corium

Target motorials Thorium motal (.1-1 gm)

Typo of bbdt: $60^{\text {" al phas }}$

Mield: $80 \%$

Dogreo of purification: $10^{6}$ oxoept from other R.E. : probably $10^{3}-10^{4}$ from othor R.E.

Prooeduro: Tho Th motal is dissolvod in cone ECl plus a few drops of o 2 (IIH $)_{2} \mathrm{SLF}_{6}$ solution to oloar up tho blook rosiduo. Tho HCl is dilutod to $z$ and an aliquot taken.

(1) idd $10 \mathrm{mg} C$, La and $Y$ oarricrs, $8 \mathrm{ml}$ cono. Hio 3 and $15-20 \mathrm{ml}$ $.35 \mathrm{MHIO}$ oolution. Contrifugo.

(2) Idd $12 \mathrm{ml}$ of $15 \mathrm{~N}$ WaOH, ppt Co(OH) $3^{\circ}$ Tash onoo with dil NaOH.

(3) Dissolvo ppt in $2 \mathrm{ml} 6 \mathrm{I} \mathrm{HCl}$. Dil to $10 \mathrm{ml}$. Add $2 \mathrm{ml} 27 \mathrm{IIF}$. Ppt $\mathrm{CoF}_{3}$, disoard suporñato.

(4) idd $1 \mathrm{ml}$ sat $\mathrm{B}_{3} \mathrm{BO}_{3}$ and $8 \mathrm{ml}$ cono. $\mathrm{ENO}_{3}$. Fhon dissolved add $1 / 4$

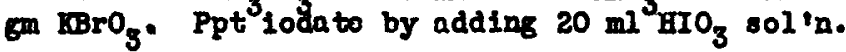

(5) Dissolvo ppt in 1 drop oono $\mathrm{HCl}$ and 3 drops $\mathrm{H}_{2} \mathrm{O}_{2}$ and ropeat lodato ppton.

(6) Dissolvo Iodato in 1 drop $\mathrm{BCl}$ and add $8 \mathrm{ml}$ cono. Hro and $10 \mathrm{mg}$ $\mathrm{Zr}$ carrior. Lidd $\mathrm{HIO}_{3}$ to ppt $\mathrm{Zr}\left(\mathrm{IO}_{3}\right)_{4}$, lot stand $5 \mathrm{mIn}$. Contrifugo.

(7) Idd $10 \mathrm{ml} 15 \mathrm{~N} \mathrm{MOH}, \mathrm{ppt} \mathrm{Co}(\mathrm{OH})_{\mathrm{S}^{\circ}}$

(8) D28solvo $\mathrm{Co}(\mathrm{OH})_{3}$ in $1 \mathrm{ml} 6 \mathrm{~W} \mathrm{HCl}$. Add $\mathrm{H}_{2} \mathrm{SO}_{3}$ to reduoo all IO $\mathrm{IO}_{3}^{-}$to I. Sdd $\ln _{4}$ OH to ppt $\mathrm{Co}(\mathrm{OB})_{3}$.

(9) Dissolvo Co(OH) 5 in $1 \mathrm{ml} 6 \mathrm{y} \mathrm{ECl.} \mathrm{Dil} \mathrm{to} 15 \mathrm{ml} \mathrm{H}_{2} \mathrm{O}$, boil. Add $15 \mathrm{ml}$ sat $\mathrm{H}_{2} \mathrm{CrO}_{4}^{\mathrm{s}}$ with $\mathrm{tirring}$. Cool in 100 bath just $10 \mathrm{~min}$.

(10) Flltor, wash throe $t$ imos with $5 \mathrm{ml} \mathrm{H} \mathrm{H}_{2}$, throo timos with $5 \mathrm{ml}$ EtOF, threo timos with $6 \mathrm{ml}$ Bt, 0 . Diry by ovas. 2 min., relosso, 2 min., rolonso, 3 min., wolgh as $C_{2}\left(C_{2} \mathrm{O}_{4}\right)_{3} \cdot 1 \mathrm{OH}_{2} \mathrm{O}$.

Romarzs:

This mothod has bocn dosoribod proviously (Phys. Rov. 7517 (1949)).

Proparation of oarrior solution: Dissolvo 31.0 ms $\mathrm{Co}\left(\mathrm{NO}_{3}\right)_{3} \cdot 6 \mathrm{H}_{2} \mathrm{O}$ in water and diluto to ono liter.

Standardization: Tako $5 \mathrm{ml}$ carrior. idd $20 \mathrm{ml} \mathrm{H} 0$. Hont to boiling and add $5 \mathrm{ml}$ saturatod oralio aojd. Cool in an to bath for just 10 minutos. 


\section{$58-1$ (pago 2)}

Filtor through a fine sinterod glass cruciblo. Frash and dry with $5 \mathrm{ml}$ $\mathrm{H}_{2} \mathrm{O}, 3-5 \mathrm{ml}$ portions $95 \% \mathrm{EtOH}, 3-5 \mathrm{ml}$ portions $E t_{2} \mathrm{O}$. Bracuate 2 minutos, relcaso to air, ovacua io 2 min., roloase, opccuato, relorso (ovaouato throo ininutes). Woigh as $\mathrm{Co}_{2}\left(\mathrm{C}_{2} \mathrm{O}_{4}\right)_{3} \cdot \mathrm{IOH}_{2} \mathrm{O}$.

The mothod is quito ompirioal. The Rare Barth ppts aro woighed as the follotving compositions when dried in tho abovo standard manner.

$$
\begin{aligned}
& \mathrm{Ia}_{2}\left(\mathrm{C}_{2} \mathrm{O}_{4}\right)_{3} \cdot 8 \mathrm{H}_{2} \mathrm{O} \\
& \mathrm{Co}_{2}\left(\mathrm{C}_{2} \mathrm{O}_{4}\right)_{3} \cdot 1 \mathrm{OH}_{2} \mathrm{O} \\
& \mathrm{Pr}_{2}\left(\mathrm{C}_{2} \mathrm{O}_{4}\right)_{3} \cdot 9 \mathrm{H}_{2} \mathrm{O} \\
& \mathrm{Y}_{2}\left(\mathrm{C}_{2} \mathrm{O}_{4}\right)_{3} \cdot 7 \mathrm{H}_{2} \mathrm{O} \\
& \mathrm{Eu}_{2}\left(\mathrm{C}_{2} \mathrm{O}_{4}\right)_{3} \cdot 1 \mathrm{OH}_{2} \mathrm{O}
\end{aligned}
$$

\section{$8 / 23 / 49$}


Element separated: Cerium

Targot material: N I E BI wotal

Type of bbdt: 184" all partioles
Prooedure by: Goeckermann Time for sep'n: few hours

Bquipment required: Centrifuge, tubes, lusteroid cones, $\mathrm{H}_{2} \mathrm{~S}$ tank, $\mathrm{NH}_{3} \tan \mathrm{k}$, ozone generator.

Yie 1d: Ce approx. 30\%

Degree of purifioation: Ce decontamination faotor $>10^{4}$ from fission \& spallation produots.

Advantages: Good for'separating small amounts of Co \& Bu aotivity from largo amts of non-RE aotivities.

Prooedure: Cerium and europium were purified together and then separated frow the other rare earths.

(1) To aliquot of $\mathrm{HWO}_{3}$ soln of target add $20 \mathrm{mg} \mathrm{Co,} \mathrm{Eu,} \mathrm{and} \mathrm{Y}_{\text {. Ialco }}$ 2N in BCl with $\mathrm{Zr}$, $C$, and $\mathrm{Sr}$ present and precipitate RE fluorides.

(2) Dissolvo and reprooipl ta to $\mathrm{RB}$ fluorides from 2 II $\mathrm{HHO}_{3}$ with $\mathrm{Zr}$ and $\mathrm{Cb}$ present.

(3) Sosvenge twioe with $\mathrm{BI}_{2} \mathrm{~S}_{3}$ and Rus from 0.5 E ECl.

(4) Preoipitate IBS hydroxides twioe with $\mathrm{KH}_{3}\left(\mathrm{CO}_{3}^{-2}\right.$ free) and $\mathrm{Sr}$ present.

(5) Prooipitato RE Pluorides from 2I BCI trioe with $2 x$ and Cb present.

(6) Soavenge with $\mathrm{BI}_{2} \mathrm{~S}_{3}$ and RuS from $0.3 \mathrm{HCl}$.

(7) Proolpitate RE hydroxides with $\mathrm{MH}_{3}$ three times with Sr present.

(8) Preolpitate RE oxalates from dilute ECl.

(9) Preoipitate RE fluorides from $\mathrm{HIO}_{3}$.

(10) Ropeat (7).

(11) Displece air with $\mathrm{O}_{2}$ and $\mathrm{CO}_{2}$ free $\mathrm{H}_{2}$, reduce with $\mathrm{Zn}$ amalgam, preolpitate $\mathrm{Y}(\mathrm{OH})_{3}$ and $\mathrm{C}_{0}(\mathrm{OH})_{3}$ with $^{2} \mathrm{iH}_{3} \cdot \mathrm{D}_{1880} \mathrm{lve}$ and reduoe again, reprooipita to hydroxides.

(12) Dissolvo 'hydroxidos, preoipitate $\mathrm{Ce}\left(\mathrm{IO}_{3}\right)_{4}$ twice, then $\mathrm{Ce}_{3}\left(\mathrm{PO}_{4}\right)_{4}$ three timos. Preoipitato CeF from HCI, motathesize to $\mathrm{Ce}_{\mathrm{O}}(\mathrm{OH})_{\mathrm{z}}^{4}$. dissolve in ECl, preolpitate $\mathrm{Co}(\mathrm{OH})_{3}$ with $\mathrm{MH}_{3}$. Dis801vo in HCI. Noich as $\mathrm{Ce}_{2}\left(\mathrm{C}_{2} \mathrm{O}_{4}\right)_{3} \cdot 1 \mathrm{OH}_{2} \mathrm{O}(25.84 \mathrm{mf}$ per $10 \mathrm{mg} \mathrm{Ce})$.

Remarles: In these bbdts, the amount of $Y$ aotivity produoed was $>10^{3}$ cimes the RB aotivity. 1-2 mg of holdback oarriers or scavengers are used. $8 / 24 / 19$

See (63-3) for Europium separation from same target. 


\section{CEEMICAL SBPiRiTIOAS}

Elomont scparatod: Samarium

Targot matorial: Thorium motal (.1-1 gm)

Procedure by: Ballou, Nowton

Typo of bbdt: 60" alphas

Timo for sop'n: $\sim 2$ hours

Equipmont roquired: Purifiod tank $\mathrm{N}_{2}\left(\mathrm{O}_{2} \& \mathrm{CO}_{2}\right.$ froo $)$

\section{Y10 1d: 5-25\%}

Dogroe of purification: undotorminod

Proooduro: Tho Th motal is dissolvod in cono $\mathrm{HCl}+$ a fow drops of $2 \mathrm{M}$

(IMH, SiF solution to oloar up the black residuc. Tho HCl is dilutod

to 2 and an aliquot taken.

(1) Add $10 \mathrm{mg} \mathrm{Co}^{+3}$ and $\mathrm{Eu}^{+3}$ carricr $+10 \mathrm{mg} \mathrm{Sm}^{+3}$ carricr, $5 \mathrm{ml}$ conc.

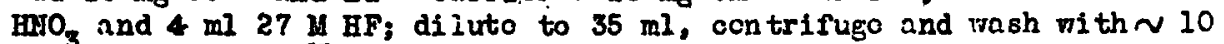
ml $\mathrm{H}_{2} \mathrm{O}+$ scveral drops HF.

(2) Dissolve ppt in $1 \mathrm{ml}$ sat $\mathrm{H}_{3} \mathrm{BO}_{3}+3 \mathrm{ml}$ conc InjO , diluto to $\sim 20 \mathrm{ml}$, add $2 \mathrm{ml} 27 \mathrm{II} \mathrm{HF}$, contrifugo and wash as in (1).

(3) Slurry ppt of (2) with $1 \mathrm{ml}$ sat $\mathrm{H}_{3} \mathrm{BO}_{3}$ solution and dissolve in $8 \mathrm{ml}$ cono $\mathrm{HNO}_{3}$. idd $0.2 \mathrm{gm} \mathrm{KBrO}_{3}+20 \mathrm{ml} 0.35 \mathrm{M} \mathrm{KIO}_{3}$ sol' $\mathrm{n}$; $\mathrm{cool}$ and stir 2 mirutes. Contrifugo $z_{\text {e }}$ wash vith $\mathrm{H}_{2} \overline{\mathrm{O}}$. (Ppt contains Ce and Th.)

(4) Sdd $12 \mathrm{ml} 19 \mathrm{M}$ HaOH to supn, cool and contrifugo. Dissolvo ppt in cono. $\mathrm{HCl}+\mathrm{H}_{2} \mathrm{SO}_{3}$, dilute to $30 \mathrm{ml}$, add cono. $\mathrm{HH}_{4} \mathrm{OH}$, centrifuge and wash.

(5) Dissolve ppt in $3 \mathrm{ml} 6 \mathrm{~N} \mathrm{HCl}$, dilute, add $5 \mathrm{mg}$ La holdback carrier, and reppt with $\mathrm{MH}_{4} \mathrm{OH}$; centrifuge and wash.

(6) Dis solve the $\mathrm{Sm}(\mathrm{OH})_{3}$ \&u(OH) 3 with a minimum of $6 . \mathrm{N} \mathrm{HCl}$ (not more than a fow drops) and transfer to a separatory funnel with 10-20 ml water. Add 8 drops of glacial $\mathrm{HAc}$ and 3 to $4 \mathrm{ml} \mathrm{Na}$ amalgam $(0.3 \%)$ (Note 1).

(7) Shake for 5-10 seconds (Noto 2) and transfer the $\mathrm{Hg}$ layer to a second separatory funnel oontaining $\sim 30 \mathrm{ml}$ water. Shake and then transfer to a third sunnel also containing $\sim 30 \mathrm{ml}$ water (Nate 3). Shake and transfer to a fourth funnel contalning $\sim 20 \mathrm{ml} 2 \mathrm{~N} \mathrm{HCl}$. Shake until $\mathrm{H}_{2}$ ovolution oeases (Note 4)

(8) Colloot the Hg in a recovery bottle and pass the vater layer into a centrifuge tube. Add $5 \mathrm{mg}$ La holdback carrier and precipi tate with aonoentrated $\mathrm{NH}_{4} \mathrm{OH}$.

(9) Repeat steps (6-8) twice (Note 5).

(10) Dissolve the $\mathrm{Sm}(\mathrm{OH})_{3}$ and $\mathrm{Eu}(\mathrm{OH})_{3}$ with $1 \mathrm{ml} 6 \mathrm{~N} \mathrm{HCl}$ and transfer to a $50 \mathrm{ml}$ oonstriotod neok oentrifuge tube (BKH :" 20972) containing 0.5 gm amalgamatod $2 n$. 
(11) Dilute to $\sim 8 \mathrm{ml}$, and heat the mixture with stirring using as a stirring rod a drawn out tube through which is passing a strean of carbon-dioxide free and oxygen free nitrogen (Noto 6 ).

(12) Using the samo tube as a stirring rod, place the contrifuge tube in an ioe bath and add carbonate-free $\mathrm{NH}_{4} \mathrm{OH}$ to precipitate the $\mathrm{Sm}(\mathrm{OH})_{3}$. Close tho tube with a tight fitting rubber stopper and contrifuge.

(13) Deoant into another tube and test for Bu by passing in ozone. Continue extracting $\mathrm{Bu}$ from the Sm as described above until no more Eu appears in the cont rifugato.

(14) Add I me more $\mathrm{Eu}$ to the $\mathrm{Sm}(\mathrm{WH})_{3}$ and ropeat stops (10-13). (Save all Eu residues.)

(15) Dissolve the final $\operatorname{Sm}(\mathrm{OH})_{3}$ with a minimum of $6 \mathrm{HHCl}$ (not over $1 \mathrm{ml}$ ), dilute to $\sim 15 \mathrm{ml}$, hoat wi th otirring, and add $\mathrm{TO}-15 \mathrm{ml}$ hot saturated oxalio acid with stirring. Filter through a filtar ofrolo on a Hirsoh funnel, and wash trice with dilute oxalic aoid, onoe with vater, and opoe with alcohol. Ignite the sample and mount for counting.

Notes

1. The $\mathrm{Na}$ should be cleaned with other and be allowed to dry before adding to the Hg. The amalgamation of the prooesds with considerable hoat ovolution, causing some volatilization of the Hg. Consequentiy, the preparation of the amalcam should be done in the hood under nitrogen. The residue which is also formed can be removed by filtering the amalgam through a small hole in a filter paper. Inis residue which oontains some amalgam can be washod several times with water and used. Once formed, $\mathrm{Na}$ amalgam is relatively stable to water and air but decomposes readily in acid solutions.

2. Shaking much longer causes complete destruotion of the Na. This should bo avoided. On the other hand, sufficient time must be allowed for the Sin to amalgama to complotely.

3. No Sm is lost in the water washings. Henoe these may be discarded.

4. Sm (and $\mathrm{Bu}$ ) are completely removed by $2 \mathrm{~N} \mathrm{HCl.} \mathrm{None} \mathrm{of} \mathrm{the} \mathrm{other} \mathrm{rare}$ oarth fission produots are extracted in this step. If the yleld of Sm appears low, add more amalgam to the first fumel and repeat the separation. Any Sm remaining in the first funnel should bo saved.

5. It is probably necessary to repeat paragraph (2) only once. Howevor, this has not been testod.

6. The nitrogen frgm the tank is passed through a tube containing $\mathrm{Cu}$ heated to $\sim 400^{\circ} \mathrm{C}$. $\mathrm{CO}_{2}$ is removed by passing the $\mathrm{H}_{2}$ through an Asoarite tube. Reduced Eu is roadily oxidized by oxygen and henoo oxygen must be excluded. Carbon dioxide forms insoluble carbonatos and must also bo avoided. 
62-1 (page 3)

Seo: L. Hinsbeig Paper 195 Radiochemical Studies: The Flssion Produots, Volume 9, Div. IV, of the ifational lholear Bnorgy Series, HoGraw-Hill

Publishing Co. (1950).

This mothod has boen dosoribod proviously (Phys. Rev. 7517 (1949)).

$8 / 23 / 49$

P-18-269 
83-1

\section{CHELTCAI SBPARA TIOKS}

Element separated: Europium

Target matertal; Thorfum (motal)

Jupe of bbdt: $60^{\prime \prime} \mathrm{C}^{\prime} \mathrm{B}$
Proeedure by: Newton

Time for sep'n: 4 hrs.

Equipment required: Tank $\mathrm{N}_{2}$ $\left(\mathrm{O}_{2}\right.$ and $\mathrm{CO}_{2}$ free $)$.

Yiteld: $40 \%$

Degrec of purtefoation: $10^{6}$ exoept from R. E.i is $10^{4}$ from R. B.

iPrecature: The Th motal is dissolved in cono $\mathrm{HCl}+$ a lew dro $\mathrm{s}$ of ..2 $\mathrm{H}$ (ifl, $), 81 F$ solution to clear up the black residwe. "The Hal is diluted to 2 'f and en a liquat taken.

(1) To altquat add $10 \mathrm{mg} \mathrm{Bu}^{+++}$and $10 \mathrm{mg} \mathrm{Co}^{+++}$carrtars. Add $8 \mathrm{ml}$ cono $\mathrm{HIOO}_{3}$ and $20 \mathrm{ml} 0.36 \mathrm{~N} \mathrm{HIO}_{3}$ soln. Ppt $\mathrm{Th}\left(\mathrm{IO}_{3}\right)_{4}$. Discard apt.

(Z) To centrifugate add $19 \mathrm{M} \mathrm{NaOH}$ ppt $\mathrm{Ce}(\mathrm{OK})_{3}$ and Bu(OH) $)^{\circ}$ Contringe and wash ppt onee with $\mathrm{H}_{2} \mathrm{O}$.

(\$) Bissolwe ppt in $8 \mathrm{ml}$ com $\mathrm{HHO}_{3}$, add $2 \mathrm{ml} \mathrm{Zr}$ and $20 \mathrm{ml} \mathrm{HIO}_{3}$ gpt $\mathrm{Zr}\left(\mathrm{IO}_{3}\right)_{4}$. Centrifuge and discard ppt.

(4) Adj $19 \cdot \mathrm{M} \mathrm{MaOH}$ to pgt $\mathrm{Bu}(\mathrm{OH})_{3}$ and $\mathrm{Co}(\mathrm{OF})_{3}$. Biseard sauparmate. Fash ppt conoe vith $\mathrm{H}_{2} \mathrm{O}$.

(5) Dtecalve hydroxides in $1 \mathrm{nl} 6 \mathrm{y} \mathrm{HCl.} \mathrm{Add} 10 \mathrm{mb}$ reabh Ba axid $\mathrm{Sr}$

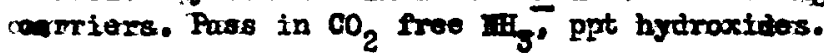

(6) Fropoat (5).

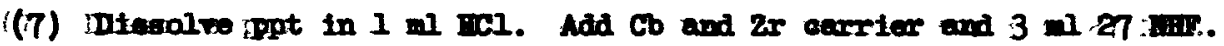

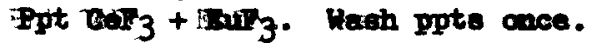

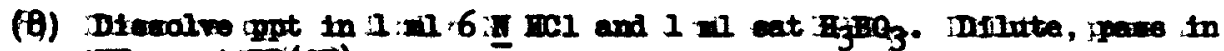
$\mathrm{Nuin}_{3}$, ppt tois $(0,)_{3}$

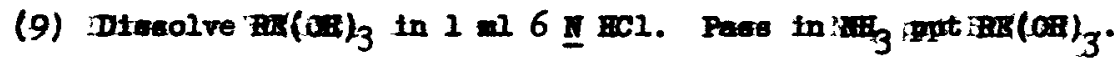

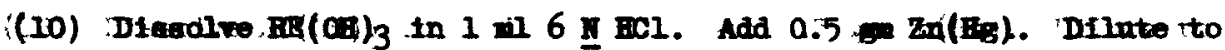

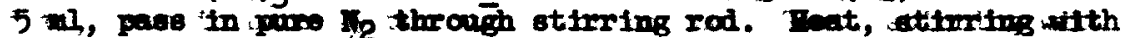

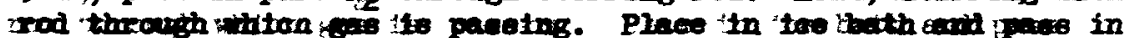

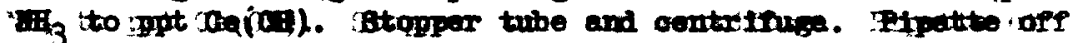

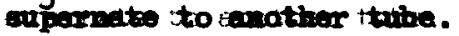

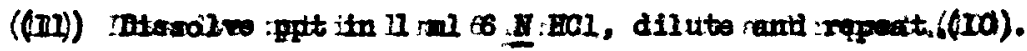


(12) To oombined supernates of 10 and 11 add 1 drop hocl (6\%) or pass in ozono. Ppt Bu(OH) 3 ; Contrifuge. Dissolvo in 6 II $\mathrm{HCl}$ and repeat 10,11 , and 12 .

(13) Dissolve $\mathrm{Bu}(\mathrm{OH})$ from (12) in $1 \mathrm{ml} 6 \mathrm{M} \mathrm{BCl}$. Dilute to $10 \mathrm{ml}$. Heat. Add $10 \mathrm{ml}$ saturated $\mathrm{H}_{2} \mathrm{C}_{2} \mathrm{O}$ and place in ioe bath $10 \mathrm{~min}$. Filter on weighed filter papor and wash throe timos with $5 \mathrm{ml} \mathrm{H}_{2} \mathrm{O}$, throe times with $5 \mathrm{ml}$ Btog and throe times with $5 \mathrm{ml} \mathrm{Bt}$ Evaouate and weigh.

Bomarks:

(1) $\mathrm{N}_{2}$ gas must be $\mathrm{O}_{2}$ and $\mathrm{CO}_{2}$ froe.

(2) Save all Bu residues, aotive or not. Bu is extremely rare and hard to get.

This mothod has heen desoribed proviously in Phys. Rev. 75, 27 (1949).

\section{$8 / 11 / 49$}

P-18-160 
Proparation of Europium Carrier

$\sim 2.5$ gms of ouropium oxalate originally prepared by lifcoy was purified. There are both $\alpha$ and $\beta$ aotivities associated with this $\mathrm{Eu}$ and it is necessary to separate it in order to obtain a good carrier solution.

The process was:

(I) $\mathrm{Bu}_{2}\left(\mathrm{C}_{2} \mathrm{O}_{4} \frac{j}{3}\right.$ gnitod and dissolved in $\mathrm{HCl}$.

(2) $\mathrm{NH}_{4} \mathrm{OH}$ passed in to ppt $\mathrm{Bu}(\mathrm{OH})_{3}$.

(3) $\mathrm{Bu}(\mathrm{OH})_{3}$ dissolved in $10 \mathrm{ml} 16 \mathrm{II} \mathrm{HNO}_{3}, \mathrm{Zr}^{++++}$oarrier added.

(4) $\mathrm{HIO}_{3}$ added to ppt $2 \mathrm{r}\left(\mathrm{IO}_{3}\right)_{4}$ oarrying all in impurities.

(5) $19 \mathrm{~N} \mathrm{NaCH}$ added to ppt $\mathrm{Eu}(\mathrm{OH})_{3}$.

(6) $\mathrm{Bu}(\mathrm{OH})_{3}$ dissolvod in $6 \mathrm{~N} \mathrm{HCl}$. $\mathrm{Ba}^{++}$added and $\mathrm{H}_{2} \mathrm{SO}_{4}$ added while hot to $\mathrm{ppt} \mathrm{BaSO}_{4}$, oarrying Ba and 14 sth activitios.

(7) $\mathrm{Eu}(\mathrm{OH})_{3}$ pptd with $\mathrm{MH}_{4} \mathrm{OH}$, washed and dissolved in dilute $\mathrm{HCl}$.

(8) $2 \mathrm{n}(\mathrm{Hg})$ added to reduoe $\mathrm{Eu}$ with $\mathrm{N}_{2}$ bubbling through solution. Then $\mathrm{HH}_{3}$ passed into ppt $\mathrm{R}$. B. and $\mathrm{Ao}^{2}$ hydroxides. Ppt rodissolrod in aold and rooyclod sinoe som bu not reduoed.

(9) $\mathrm{Bu}^{++}$oxidised with $\mathrm{KaCl}$ and ppt'd as hydroxide, washed and dissolved in $\mathrm{HCl}$ as oarrier.

\section{Standardization of Carrier}

Take 2 ml oarrier solution, heat and ppt oxalate with $\mathrm{H}_{2} \mathrm{C}_{2} \mathrm{O}_{4}$. COOl 10 min in 100 bath, filter. Wash three times with $5 \mathrm{ml} \mathrm{H}, \mathrm{O}$, three times with $5 \mathrm{ml}$ Etoll and three timos with $5 \mathrm{ml} \mathrm{Et}{ }_{2} \mathrm{O}$. Dry by ovaouation. Feigh as the oxalate. Ignite to oxide and weigh as the oxide.

$$
\mathrm{Bu}_{2}\left(\mathrm{C}_{2} \mathrm{O}_{4}\right)_{3} \cdot 10 \mathrm{H}_{2} \mathrm{O} \text { (24.6 mg per } 10 \mathrm{mg} \mathrm{Bu} \text { ). }
$$

A. S. Newton

\section{$8 / 11 / 49$}




\section{CHEMTCAL SEPARAT IONS}

Element separated: Europium

Target material: 1 g Bi motal

Type of bbdt: $184^{\prime \prime}$ all partioles
Procedure by: Goeckermann

Time for sepin: few hours

Bquipment requirud: Centrifuge, tubes, lusteroid cones, $\mathrm{H}_{2} \mathrm{~S}$ tank, $\mathrm{MH}_{3}$ tank, ozone gênerator.

Yield: Eu approx. 15\%

Degree of purification: Eu decontamination factor $>10^{4}$ from non-RE fission and spallation products.

Advantages: Good for separating small amounts of Ce Eu activity from large ants of non-RE aotivities.

Procedure: Cerium and europium wore purified together and then separated from the other rare earths.

(1) To aliquot of $\mathrm{INO}_{3}$ soln of target add $20 \mathrm{~m} \cdot \mathrm{Co}$, Eu and $\mathrm{Y}$. Make 2N in $\mathrm{HCl}$ with $\mathrm{Zr}^{3}, \mathrm{Cb}$, and $\mathrm{Sr}$ present and prooipitate $\mathrm{RB}$ fluorides.

(2) Dissolve and roprecipitate $\mathrm{RE}$ fluorides from $2 \mathrm{~N} \mathrm{HNO}_{3}$ with $\mathrm{Zr}$ and $\mathrm{Cb}$ present.

(3) Scarenge tric $\theta$ with $\mathrm{BI}_{2} \mathrm{~S}_{3}$ and RuS from $0.5 \mathrm{~N} \mathrm{ICl}$.

(4) Precipitate RE hydroxides twioe with $\mathrm{MH}_{3}\left(\mathrm{CO}_{3}^{-2}\right.$ free) and $\mathrm{Sr}$ present.

(5) Precipitato RE fluorides from $2 N$ HCl twioo with $\mathrm{Zr}$ and Cb present.

(6) Scavengo with $\mathrm{Bi}_{2} \mathrm{~S}_{3}$ and RuS from $0.3 \mathrm{H} \mathrm{ECl}$.

(7) Precipitate $\mathrm{RE}$ hydroxides with $\mathrm{NH}_{3}$ three times with $\mathrm{Sr}$ present.

(8) Precipitate RE oxalatos from dilute ECl.

(9) Precipitate RE fluorides from $\mathrm{BNO}_{3}$.

(10) Repeat (7)

(11) Displace air with $\mathrm{O}_{2}$ and $\mathrm{CO}_{2}$ froo $\mathrm{H}_{2}$, reduce with $\mathrm{Zn}$ ama Igam, procipitate $\mathrm{Y}(\mathrm{OH})_{3}$ and $\mathrm{Ce}(\mathrm{OH})_{3}$ with $\mathrm{NH}_{3} \cdot \mathrm{Dissolve}_{2}$ and reduco again, reprecipitate hydroxides.

(12) Eu - Oxidize supernatants from hydroxido preoipitations with ozone, procipitate $\mathrm{Eu}(\mathrm{OH})_{3} \mathrm{witi}, \mathrm{NH}_{3}$. Dissolve in $\mathrm{HCl}$, add $\mathrm{Ce}$, roduce to $\mathrm{Eu}^{+2}$ and proofpitate $\mathrm{Ce}(\mathrm{OB})_{3}$. Repeat separation oyclo three times. Precipitate $\mathrm{Bu}_{2}\left(\mathrm{C}_{2} \mathrm{O}_{4}\right)_{3}{ }_{1 i k e} \mathrm{Y}_{2}\left(\mathrm{C}_{2} \mathrm{O}_{1}\right)_{3}$ and treat similarly. To $2 \mathrm{Eh}$ as $\mathrm{Bu}_{2}\left(\mathrm{C}_{2} \mathrm{O}_{4}\right)_{3} \cdot 10 \mathrm{H}_{2} \mathrm{O}^{2}(24.6 \mathrm{me}$ por $16 \mathrm{mg} \mathrm{Eu})$. Soo (58-2) for corium soparation from tho samg targot. In thesc bbdts, tho amount of $Y$ activity producod was $>10^{3}$ timos tho $\mathrm{RE}$ activity. $1-2 \mathrm{mg}$ of $8 / 24 / 49$ holdback oarricrs or scavengors arc usod. 
Elerant separatad: Hafnium

Target material: $\quad \mathrm{Lu}_{2} \mathrm{O}_{3}$

Type of otdt: $60^{\text {n }}$ or $184^{\text {th }}$

Y1eld: Very good

Degree of purifloation: very good
Procedure by: Hicks, Tilitins on

Time for sep'n: $1 / 2 \mathrm{hr}-\mathrm{ll} \mathrm{hr}$.

Equipment required: Ius terold tubes

Prooodure:

(1) Dissolvo $\mathrm{Lu}_{2} \mathrm{O}_{3}$ in $\mathrm{HlO}_{3}$, add oarriers (see remarks), transfer to lus, terold, holt in wator bath and add 5 oc oonc. Er.

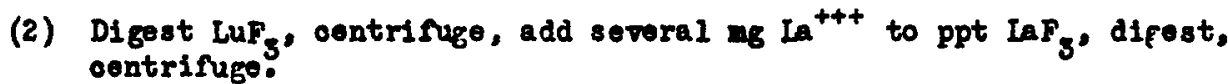

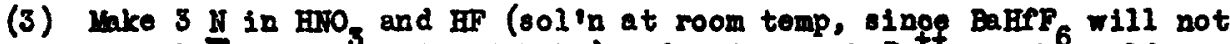
dissolve if mrecipitated hot.) and add onough Ba ${ }^{++}$in the oold to ppt BafrF $6^{\circ}$. Wash with wator.

(4) Dis solve in $\mathrm{HiO}_{3}-\mathrm{H}_{3} \mathrm{BO}_{3}$ mixture (8-10 $\mathrm{M} \mathrm{BrO}_{3}$ saturated with $\mathrm{H}_{3} \mathrm{BO}_{3}$ ),

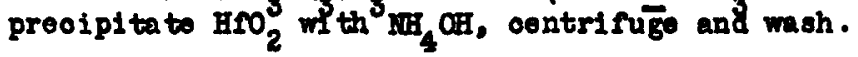

Ramarka: About 20 mg samplos of $\mathrm{Lu}_{2} \mathrm{O}_{3}$ have been bombarded. Holdback oarriers added in (1) onn inolude $I$ ing portion of as many olements forming soluble fluorides as thought noovssary by the conditions of the bombardment. $\mathrm{Zr}$ can be used as oarrior for HF.

The Balle 6 prooipitation desoribed here is spooifio for Hf and $2 x$.

$6 / 25 / 49$

P-18-13 
Element separated: Ilafinium

Target material: $\mathrm{Ta}, \mathrm{HfO}_{2}, \mathrm{~W}$

Type of bbdt: $60^{\prime \prime}$ or $184^{\prime \prime}$

Yield, very good

Degree of purification: very rood
Procedure by: Hicks,

Time for sep'n: $1 / 2 \mathrm{hr} .-1 \mathrm{hr}$.

Equipment required:

Platinum dish

lusteroid tubes

\section{Procedure:}

(1) Dissolve $\mathrm{T}, \mathrm{Ta}$, and $\mathrm{HFO}_{2}$ in $\mathrm{HF}$ and $\mathrm{HNO}_{3}$, transfer to lus teroid tube and add carriers. (See remarks.)

(2) Heat in hot water bath, add several $\mathrm{La}^{+++}$to Ppt LaF ${ }_{3}$ oentrifuge, repeat $\mathrm{LaF}_{3} \mathrm{ppt}$.

(3) Jake supn $3 \mathrm{~N}$ in HNO and $\mathrm{HF}$, making sure solution is at room temperature for BaHfl vill not dissolve if precipitated hot. Add enough $\mathrm{Ba}^{++}$to completely preoipitate BaHfF $6^{\circ}$ Wesh with dilute HF and then rater.

(4) Dissolve BaHfF in $\mathrm{HNO}_{3}-\mathrm{H}_{3} \mathrm{BO}_{3}$ mixture (8-10 $\mathrm{H} \mathrm{InO}_{3}$ saturated with $\mathrm{H}_{3} \mathrm{BO}_{3}$ ), precipitate $\mathrm{HfO}_{2}$ with $\mathrm{NH}_{4} \mathrm{OH}$, contrifuce and wash with vater.

Remarks: Gram amounts of $\mathrm{W}$ and $\mathrm{Ta}$ are usually bombarded. $\mathrm{HfO}_{2}$ is bombarded in about 20 or $30 \mathrm{mg}$ samples.

Add any holdback carriers (of ol ements forming soluble fluorides and $\mathrm{Zr}$ ) neoeseary hero in mg amounts. $\mathrm{Zr}$ can be used as odrrier for Hf.

$\mathrm{L}_{4.3} \mathrm{BaHFF}_{6}$ preoipitation described here is specific for Hf and $\mathrm{Zr}$.

$6 / 25 / 49$

P-18-12 


\section{CHEUICAL SEPAJATIONS}

Element saparated: Tantalum

$$
\begin{aligned}
& \text { Procedure by: Hicks, } \\
& \text { Tilkinson }
\end{aligned}
$$

Target material: $\quad \mathrm{Lu}_{2} \mathrm{O}_{3}$

Timo for sepin: $1 / 2 \mathrm{hr}-1 \mathrm{hr}$.

Type of bbdt: $60^{\prime \prime}$ or $184^{n}$

Equipment required: lusteroid tubes

Yield: vory good

Degree of purification: very good

Prooeduro:

(1) Dissolve $\mathrm{Lu}_{2} \mathrm{O}_{3}$ in $\mathrm{HNO}_{3}$, transfer to Iusteroid tube and add $\mathrm{Th}$ carrier. $\left(\mathrm{Ta}_{2} \mathrm{O}_{5}\right.$ may opt but vili dissolve in HF)

(2) Heat sol'n in water batl, add 5 cc cono. HF, digest for 2 - 3 minutes until $\mathrm{Ta}_{2} \mathrm{O}_{5}$ dissolves and flocculent $\mathrm{TF}_{3}$ procipitates.

(3) Centrifugo, add several $\mathrm{mg} \mathrm{La}^{+++}$, digest flouride as above and oentrifuge.

(4) Make basic with $\mathrm{MH}_{4}$ OH to ppt $\mathrm{Ta}_{2} \mathrm{O}_{5}$.

$6 / 25 / 49$

P-I8-15 


\section{CHEHITCAL SEPARATIONS}

Element separated: Tantalum

Prooedure by: Hicks,

Hilkinson

Target material: $\mathrm{N}, \mathrm{Ta}, \mathrm{BP}$

Time for sep'n: $1 / 2 \mathrm{hr},-1 \mathrm{hr}$.

Type of bbdt: $60^{n}$ or $184^{\prime \prime}$

Equipmont required:

Pt dish, lusteroid tubes

Yield: very good

Degree of purifiontion: very good

Prooodure:

(1) Dissolve $\mathrm{T}, \mathrm{Ta}$ or $\mathrm{EfO}_{2}$ in $\mathrm{HF}$ and $\mathrm{HNO}_{3}$ in Pt dish.

(2) Transfer solution to lustoroid tube and add any holdback oarriers necessary. ( $\mathrm{Zr}$ trorks well as carrier for Hf). lake solution 3N in $\mathrm{ZMO}_{3}$ and $\mathrm{FF}$. Add enough Ba $\mathrm{Ba}^{+7}$ to pt whito BaHFF 6 completely, contrifuge, and repeat.

(3) Saturate solution with solid $\mathrm{FF}$ or $\mathrm{KHF}_{2}$ to ppt $\mathrm{K}_{2} \mathrm{TaF}_{7}$ (white), oentrifuge, and wash with cono. sol $^{2}$.

Remarks: $T$ and Ta usually bombarded in gram amounts, Bf usually in lots of $20-30 \mathrm{mg}$.

This $\mathbb{K}_{2} \mathrm{TaF}_{7}$ pptn spocifio for $\mathrm{Ta}$ and will not carry dow Cb.

$6 / 25 / 49$

P-18-10 
CHELICAL SEPARATIONS

Element separated: Tungsten

Targot material: Tantalum

Type of bbdt: $60^{\prime \prime}$ or 184"

Y10Id: $\sim 100 \%$

Degree of purification: Separates $10^{5} \mathrm{c} / \mathrm{m}$ oomplotoly from Ta and spallation products.

\section{Procedure:}

(1) Dissolve $\mathrm{T}$ in $\mathrm{HF}$ and minimum of $\mathrm{HiO}_{3^{\circ}}$ Add 20-30 ing $\mathrm{H}$ carrier (No 1088).

(2) Destroy all $\mathrm{HNO}_{3}$ with hydroxylamine or hydrazine. Hake about $2 \mathrm{H}$ in $\mathrm{HCl}$, add $0.1^{3} \mathrm{gm} 801 \mathrm{id} \mathrm{SnCl}, 0.5 \mathrm{gm} \mathrm{MH}_{4} \mathrm{SCl}$, and $\mathrm{H}_{3} \mathrm{~B} \mathrm{O}_{3}$ to complex all HF as $\mathrm{HBF}_{4}$ in that order.

(3) Heat until a bright apple green complex appears, transfer to a sep. funnel, and exuract twice with at lesst equal volume ethyl acetate.

(4) Tesh organic layer twice with equal volume $2 \mathrm{~N} \mathrm{HCl}$, and evaporato organio layer to drynoss.

(5) Take up the blue residue with $6 \mathrm{H} \mathrm{HCl}$ and 2 drop $30 \% \mathrm{H}, \mathrm{O}$ (or cono $\mathrm{HNO}_{3}$ ) and 1 drop aeroeol. Bright yellow $\mathrm{WO}_{3}$ preolpitatos after digestion on a hot water bath.

(6) Centrifuge and wash $\mathrm{rO}_{3}$ with $6 \mathrm{~N}$ acid. Then dissolvo in 100 $6 \mathrm{~N} \mathrm{NH}_{4} \mathrm{OH}$, contrifuge and discard any ppt. Ferrio hydroxido soavenges (vith $1 / 2-1$ if Fe ${ }^{++}$) may now be used for further purity but usually are not necessary.

(7) Add 5 oo cono. Hro and 1 drop of aerosol, digest on a hot water bath, centrifuge and mash $\mathrm{mO}_{3}$ formed with $6 \mathrm{I}$ aoid.

Remarks: $\mathrm{HF}_{6}$ bolls at $19^{\circ} \mathrm{C}$ so don't boll target sol'n any more than necessary.

\section{$6 / 25 / 49$ \\ P-18-16}




\section{GEMICAL SEPARATIOHS}

Element separated: Rhonsum

Target matorial: Ta,

Type of bbat: $60^{n}$ or $184^{n}$

Yield: $100 \%$

Degree of purifloction: very good

\author{
Procodure by: Hicks, \\ Wilkins on \\ Tims for sepin: $1 / 2 \mathrm{hr}$. \\ Equipment requi red: \\ Pt dish \\ lusteroid tost tubos
}

Advantages: Sast and easy with good purification

\section{Prooedure:}

(1) Dissolve $\mathrm{W}$ and $\mathrm{Ta}$ in $\mathrm{HF}$ with a minimum of $\mathrm{HWO}_{3}$ in platinum disk, and Ro oarrier added.

(2) $\mathrm{H}_{2} \mathrm{~S} 18$ passed into the boiling solution for 15 minutos precipitating black Re ${ }_{2} \mathrm{~S}_{7}$. Centrifuge and wash in a lusteroid tost tube.

(3) Disselve $\mathrm{Re}_{2} \mathrm{~S}_{7}$ in 3 oc $1 \mathrm{II}$ MoH and 1 drop $30 \% \mathrm{H}_{2} \mathrm{O}_{2}$ and transfer to glass centrifuge oom

(4) Scavenge twioe or throo times with $\mathrm{Fo}_{0}(\mathrm{OH})_{3}$ ( U I me $\mathrm{Fe}^{+++}$).

(5) Reprooipitate $\mathrm{Re}_{2} \mathrm{~s}_{7}$ from strong HCl solution (add 10 oc cono. $\mathrm{HCl}$ ), contrifuge and wash.

(6) This procedure gives excellent purity, but for additional purity, the oulfide can be transferred to a still with $\mathrm{H}_{2} \mathrm{SO}_{4}$ anc tho volatilo oxide distilled in a current of air and catching the dist1llate in concentreted NaOH. 
CHEITCAL SEPARA TIONS

Elsmont separated: Osmiun

Target materialin 46 aranium motal

Type of bbdt: $284^{\prime \prime}$ all high energy partioles
Procedure by: Folger \& Hicks

Time for sepin: in $21 / 2 \mathrm{hr}$.

Equipment required: Glass stills ("Ruthenium Stills"). centrifuge, cones, loe bath, reflive oondenter.

Yield: $n 30 \%$

Degree of purfification: in $10^{4}-10^{5}$ from other fission products.

Advantages: Fairly rapid, simple mothod of obtaining Os from bull of F.P. aotifities. Operations are rendily adaptable to semi-remoto oontrol, and the activity lovel drops rapidly after the first separation.

Procedure: HAVE YO $\mathrm{HO}_{3}^{-}$PRESEUT BEFORE STEP 3.

(1) Use un $20 \mathrm{mg}$. Os carrier and dissolve target in cono. HCl under reflux. Add i 5 mb Go carrier and boll with conc. $\mathrm{HCl}\left(\mathrm{COCl}_{4}\right.$ is driven off.).

(2) Add $I^{-}$and $\mathrm{IO}_{3}^{-}$(slight $x^{\prime} 8 I^{-}$) aid boil to remove $I_{2}$.

(3) Add oone. $\mathrm{FNO}_{3}$ (SOl'n is al ready in $10 \mathrm{~N}$ in $\mathrm{B}^{+}$. Add $\mathrm{BrO}_{3}$ to make it $\sim 6 \mathrm{~N}$ in $\mathrm{HO}_{3}^{-}$) and distill in an air stroam. Catch $\mathrm{CsO}_{4}$ in $6 \mathrm{Ir} \mathrm{MaOH}$ in an loe bath. (Gives orango sol'n).

(4) Pass in $\mathrm{B}_{2} \mathrm{~S}$ to ppt OsS, (black). Aoldify with cono. BCI to $\sim 1$ II and contrifuge. Wash (Use Aorosol and heat to ald coagulation. Addition of $\mathrm{MHO}_{3}$ might $\mathrm{h} \cdot \mathrm{lp}$ ).

(5) Dissolve sulfide in cono. $\mathrm{H}_{3} \mathrm{O}_{3}$ and redistill (distillation should prooeed from 8-10 $\mathrm{N} \mathrm{HMO}_{3}$ in ah air stream). Catoh $0 \mathrm{sO}_{4}$ in $6 \mathrm{I}$ NaOH in an 100 bath.

(6) Repeat 4. (The rash may be made with $n$ I $\mathrm{H}$ HCl if desired).

(7) Dissolve the sulfide in cono. HClo, Add 16 holdback (n $5 \mathrm{mg}$ ) and 2 oc cono. $\mathrm{H}_{3} \mathrm{PO}$ (oomplexes 16$)$. Distill in an air strean, oatohing $08 \mathrm{O}_{4}$ in 6 椐 $\mathrm{HaOH}$ in an 100 bath.

(8) 7 pent 6 and

(9) Hake alightly aold with BCI. Reduoe with $\mathrm{Mg}$ motal to some lower oxidation state of $\mathrm{Os}$ (to provent loss of $08 \mathrm{O}_{4}$ ). Boill. Add $\mathrm{Y}_{5}$ and HCI as nooded to completely ppt $0 \mathrm{~s}$ metal. ${ }^{4}$ Excess 1 may be removed by washing with irem 2-6 N HCl. Weigh as 08 motal. 
76-1 (page 2)

Remarks :

(1) CAOTJON $\mathrm{O}_{3} \mathrm{O}_{4}$ is extremely toxiol

(2) In stop 4 an attempt is made to remore most of the $\mathrm{Cl}^{-}$from the sulfide so that upon dissolving and distilline, GeCl 4 will not bo carried over. This should no longer be necessary in step 6 .

(3) Any Ru contaminant remaining after step 5 will likely be carried through the rest of the procedure. For additional purification repert stops 4 and 5 .

(4) If Iodine is a I1kely contaminant, repeat step 2. 


\section{CIELICAI SEPARATIOHS}

Element separated: Osmium

Procodure by: Chu

Target material: Fhenium

Time for sep'n: $\sim 20$ min.

Type of bbdt: $60^{n}$

Bquipment required: Distilling flask

Yield: 100\%

Degree of purification: Faotor of 100 from other activitios present.

Advantages: Simplo

Prooedure:

(I) Pour the Re porrder into the distilling rlask.

(2) Add $10 \mathrm{mg}$ os oarrier and olose the flask.

(3) Insert the outlet tube of the flask into 100 cold 6 II MaOH soln (10 oc)

(4) Introduoe 300 cons $\mathrm{ErO}_{3}$ through the inlet tube of the flask.

(5) Supply a little air through the inlet tube and heat the Mask gently for the solution of $\mathrm{B}$ and the distillation of $\mathrm{CsO}_{4}$ for about 10 min.

(6) Moutralize and then aoidify the NaOH soln with $6 \mathrm{~N} \mathrm{BCl}$.

(7) Add $30010 \%$ sodium thiosulfate and hoat in water bath.

(8) Filter and oount as the brown osmium sulfide.

Romarke:

For iridium separation from same target soe (77-4).

$8 / 17 / 49$ 
Solution of Iridium metal

Place Ir in glass bomb tube of $10 \mathrm{cc}$. volume cooled in liquid $\mathrm{N}_{2}$.

Add $5 \mathrm{co}$ cone. HCl and $0.5 \mathrm{NaClO}_{3} \cdot \mathrm{Seal}$ tube with other end in

liquid $\mathrm{N}_{2}$ and allow to warm to room temperature. Heat in furnace $300^{\circ} \mathrm{C}$ for

3 hours. Ir metal is dissolved to the deep red $\operatorname{IrCl}_{0}=$

Approximate tube dimensions:

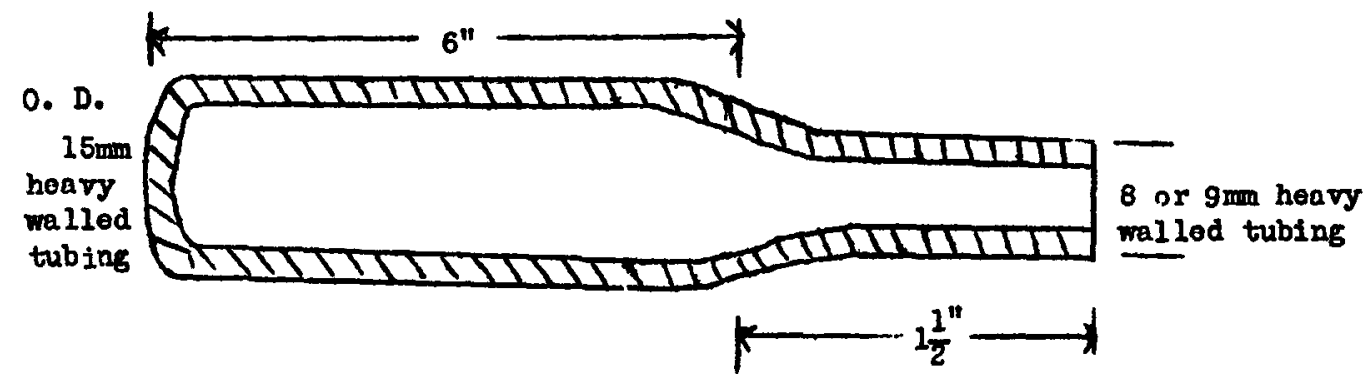

Caution: Place tube in iron pipe plugged at both ends upon removal from liquid $\mathrm{H}_{2}$. Dangor of tube exploding during the heating.

Remarles: See E. Tickers, T. G. Schlect \& C. L. Gordon J. Nat. Bur. Stand. Researoh 33, 363 (1944)

Hicles and Milkinson

P-18-27 
CHEMICAL STPARATIONS

Element soparated: Iridjum

Target material: Iridium foil

Rype of bbdt: 184' protons (any enerry)

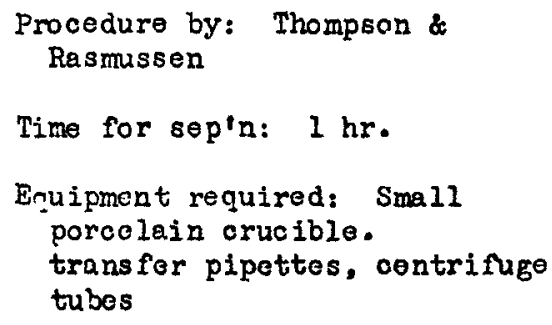

Yield: $N 5 C \%$ (de pending on stop 3)

Degreo of purification: $\Lambda t$ least faotor of 100.

¿drantoges: A simplo, reasonably fast procodure for solution and separation with a target motal (Ir) oxtremely resistant to dissolution in aqua regia.

Proceduro:

(1) liake a melt of KOH and $\mathrm{KNO}_{3}$ (approx. 50-50, not critical) in a small porcelain crucible, hoating strongly over a Fisher burner.

(2) To this hot flux add the target Ir metal, continuing to heat (and adding KOH if volume of flux gets too small) untsl the motal is completoly dissolved. (For a small strip of 1 mil foil this should take no longer than 5-10 min.)

(3) Mllow flux to cool, then leach for $\wedge 5 \mathrm{~min}$. with oonc. HCl, adding Au and $P t$ carriers in small amount. (Ir gives strong blue colored sol (n)

(4) Extraot twice with othyl acetate to remove Au.

(5) Add a little $\mathrm{SnCl}_{2}$ solution in $\mathrm{HCl}$ to the aqueous phase until a dark red coloration $\left(\mathrm{H}_{2} \mathrm{PtCl} \mathrm{I}_{4}\right.$ ) indioates the reduction of $\mathrm{Pt}$ from +4 to +2 state is complete. ${ }^{4}$ (See remarks.)

(6) 3rtract the rod coloration (Pt) into ethyl acetete. Thsh organic layer twico with equal volume of $3 \mathrm{~N}$ HCl.

After complete removal of $\Lambda u$ and $P t$, Ir can be axtreotod as follows:

(7) Rooxidize the aquoous phase from above by addifion of a mall amount of $30 \% \mathrm{H}_{2} \mathrm{O}_{2}$. (Reappearance of blue Ir coloration.)

(8) Add a little $\mathrm{mH}_{\mathrm{S}} \mathrm{SCN}$ solution. (Blue ohanges to bequtiful pink.) A precipitate of (Ir) (SCN) forms slowly. (The rato of pptn is slow enough that ono may nake use of the fact that the pink compound is oxtractiblo into ethyl acetate.) 
77-2 (page 2)

The extraotion of the pink compound has the advantage of quickly removing the Ir from the orifinel solution, which usually has onough silica dissolved (from oruciblo) that the wholo solution will $\mathrm{gel}$ if allowed to stand.

The pin's compound ppts from the ethyl aoetate on standing.

Zomarks:

As most Ir foil contains about $\Omega 1 \%$ Pt impurity, it is well to provide a step for sxtraction of Au ectivities, whether or not the Au is desired for later work, oven if it is simply a proton bombardod Ir foil.

on $\mathrm{SnCl}_{2}$ reduction the strong blue coloration of $\operatorname{Ir}(+6$ ?) disappears, permitting tho rod of reduoed $\mathrm{H}_{2} \mathrm{PtCl}_{4}$ to be scon.

By spending moro timo lcaching the molt in (3) and by using several portions of loaching arent the chemical yiolds might be mado almost quanti tative. 
CHPITICLL SEPARATIONS

Element soparatod: Iridium

Target matorial: Uranium motal ( $1 \mathrm{gm}$ )

Typo of bbdt: 388 lfev alphas
Proccdure by: Wolfe

Time for sepin: $\sim 1 / 2$ diys when soparctod with Pt and Rh

Equipmont required: Special distilling flask, contrifugo, sop. funnols

Yield: $\quad 3-5 \%$

Doerus of purification: It $100 \mathrm{st} 10^{4}$ from all fission products oxcept rhodium.

Proceduro:

(1) Cut out the contral portion of the targot and boil with oone HCl to dissolve it and to expel Ge.

(2) Add $5 \mathrm{mg} \mathrm{I}^{-}$and $\mathrm{IO}_{3}^{-}$and boil the solution agnin to expol iodino.

(3) Add $20 \mathrm{mg} 0 \mathrm{~s}, \mathrm{Ir}, \mathrm{Pt}$ and $\Lambda u$ carriers plus $20 \mathrm{mg} \mathrm{BC}, \mathrm{Ru}, \mathrm{Rh}$ and Pd carriers. Withdraw a $20 \%$ aliquot for lator dotorminations of $\mathrm{Ba}, \mathrm{Ru}$, and Rh.

(4) Place the remining solution in s speolal all-glass distilling Mask havine a thistlo tubo ontry and an air entry. Add concentratod $\mathrm{ENO}_{3}$ through the thistlo tube, and distill $\mathrm{OsO}_{4}$ into $6 \mathrm{~N} \mathrm{NaOH}$ in an 100 bath. (Save for os detomination (76-1).

(5) Place the residue from the Os distillation in a beakor, add 10 $\mathrm{ml} 70 \% \mathrm{HClO}_{4}$ and boil the solution to fumos of $\mathrm{HClO}_{4}$ to oxpel Ru.

(6) Dilute the solution, add $5 \mathrm{mg}$ more $\mathrm{Ru}$ carricr, and $5 \mathrm{mg}$ more $\mathrm{I}^{-}$and $\mathrm{IO}_{3}{ }^{-}$and ropoat the fuming.

(7) Idd onc $m$ l diluto HCl, diluto tho solution to $4 \mathrm{~N}$ and oxtract twioo with equal volume butyl acotati to dooontaminnte from He and from Au.

(8) Dilute the solution to $0.5 \mathrm{~N}$ in $\mathrm{H}^{+}$, add $5 \mathrm{ml}$ dimethylglyoximo solution (1\% in alcohol) and $\bar{f}$ lter off tho polladium ppt.

(9) Add cono $\mathrm{HCl}$ to supn to mako $\sim 5 \mathrm{~N}$. Add $\mathrm{SnCl}_{2}$ dropwiso until tho cherryred of $\mathrm{Pt}^{++}$is apparont.

(10) Extract the Pt with throo equal portions of buiyl acetate.

(11) Fumo the aquoous layor with $\mathrm{HClO}_{10}$ to prepero for th.e pyridino extraction of Rh ind Ir. (ChUIIfs: Siro tho solution contains organio matorial (dimethylglyoximo and butyl acotato), care must be trken to aroid an oxplosion. Following tho mothod of lioyes and Brey for dostroying orgnnio mterial with $\mathrm{HClO}_{4}$ add $\mathrm{HNO}_{3}$ to tho solution, ovaporate on a stoam bath for ono-half hour, then 


\section{7-3 (page 2)}

hoat gently to fumes of $\mathrm{BClO}_{4}$. $\Lambda$ dd an additional $10 \mathrm{ml}$ of $\mathrm{HClO}$ and fume the solution stronr ly for sovernl minutos to destroy tho chlorido complox of Rh and Ir.

(12) Cool the solution, dilute to $4 \mathrm{~N}$ and add $20 \mathrm{ml}$ pyridino.

(13) Boil the solution for five minutes, place in a scparatory funnol, and add $19 \mathrm{~N} \mathrm{NaOH}$ to soparate the froo-baso pyridine layor (the high concentration of $\mathrm{NOOH}$ is morely to koop tho volumo low.)

(14) Wash tho dark bluc pyridino layer threo times with equal volumos of dilute HCl, separating the layers each time with $6 \mathrm{~N}$ NaOH.

(15) Add a fow drops of $6 \mathrm{~N}$ NaOH to the pyridino layer and ovaporate the pyridine off.

(16) Pass $H_{5} S$ into the boiling alkalino solution for sevoral minutes, whilc the solution is acidifiod dropwise with $\mathrm{BCl}$. Sulfides of $\mathrm{ph}$ and Ir ppt.

(17) Dissolvo the ppt in a little aqua regia, and fume strongly with conc $\mathrm{H}_{2} \mathrm{SO}_{4}$ to convert complotoly to tho sulfate complox.

(18) Diluto the solution with water twonty to one, boil and ppt Rh motal by adding $\mathrm{IiCl}_{3}$ dropriso until a vory slight excess is presont.

(19) Dilute the supn (containing Ir) to $0.5 \mathrm{~N}$ in $\mathrm{H}^{+}, 0 \infty \mathrm{col}$ in ice and ppt Ti with oupferron. Filtor off.

(20) Add $5 \mathrm{mg}$ Pd and Pt carriors and ppt the Pd dmg. Discard.

(21) Hoat tho supornatant to boiling and neutralizo to tho brom crosol purplo ond-point wi th $\mathrm{BaHCO}_{3}$ solution, adding bromato to oxidiec the iridium up to the plus four stato. Hydratod $\mathrm{IrO}_{2}$ is preoipitatod loaving Pt in solution.

(22) Dis solvo tha ppt in a littlo oonc $\mathrm{HCl}$, and add a for mg of Rh oarrior.

(23) Fumo with $\mathrm{H}_{2} \mathrm{SO}_{4}$ and repoat the $\mathrm{Bh}$ pptn with $\mathrm{TiCl}_{3}$ (stops 18-21). Al though the $\mathrm{TICl}_{3}^{4}$ ppte of $\mathrm{Rh}$ lqaves only about $0.1 \%$ of the $\mathrm{Rh}$ in solution. Rh aotivity my bo $10^{4}$ times as high as that of Ir and honoo a sing lo separntion may still leavo several timos as much Rh aotivity in solution as Ir activity.)

(24) Aftor tho Rh pptn, ppt motallio Ir from the $B C l$ solution of the $\mathrm{IrO}_{2}$ by addition of powdored magnosium.

(25) Woigh the Ir to determino chomical yield and count.

Romarks :

Rh, Ir, and Pt should bo scparated from ono bombardment lonving O5, far and Pd for a sccond bombardment unless several people aro cooperating on tho procodure.

The yicld of activity of $0 s$, Ir, and Pt is very low in comparison vith 
that of tho othor platinum motals and many uther fission produots formod in the bombardmont. This fact nocessitates, for Ir and Pt, rigorous and repeated dooontaminction procodures which rosult in low chomical ylelds.

For othor platinum metal-fission produot soparations soo,

Platinum; 78-3

Osmium; 76-1

Ruthonium; 44-2

Rhodium; 45-1

Pnlladium;46-5

This proooduro should bo praotiood screral timos boforo actunlly applyin? it to a bombardmont, sinco in sovoral of tho steps tho conditions for soparation are quito eritioal. For this reason and for its poor ohomioal yield, this proooduro is not considored a good prooedure. To dato, howover, it is the best proooduro thet has boon worked out for miking tho roguirad soparations. It is an acooptablo proooduro from which somo radionotivity dita way be obtainod and onn sorvo as a starting point for work on othor, bottor proocdurcs.

\footnotetext{
$8 / 17 / 49$

P-18-247
} 


$$
77-4
$$

CHEIIICAL SEPARA IOMS

Element separated: Iridium

Prooedure by: Cha

Target material: Risenim

Time for sep'n: $N I$ hour

'Pype of bbdt: $60^{n}$

Equipment required: distilling ilask

Yielld: $70 \%$

Degree of purifiation: Faator of 100 from other activities pressent

Adverntages: Simple

Procetidure:

(1) Pour the porder into the distilling rlask.

(2) Add normg os oarrier and drowe the mask.

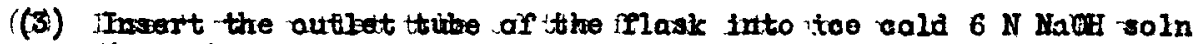
$(10-\infty)$

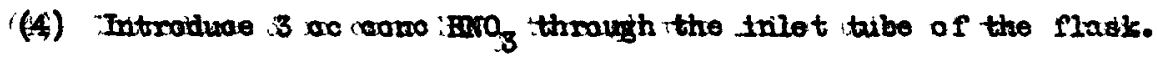

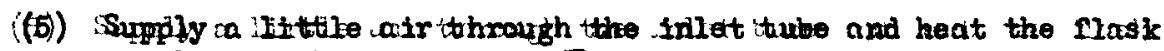

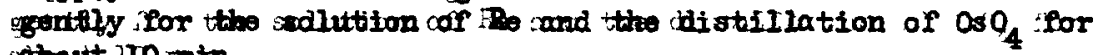
ctrout 110 mith.

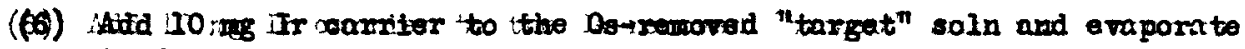
too cinforites:

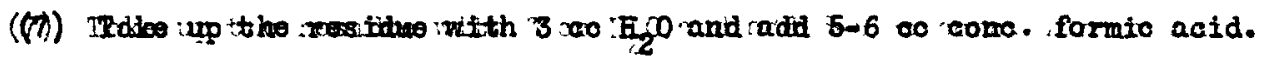

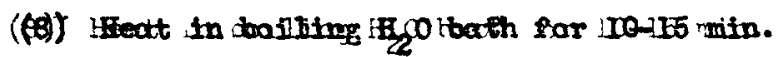

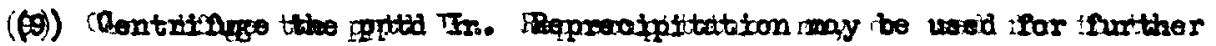

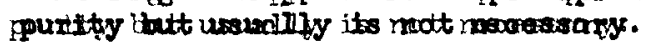

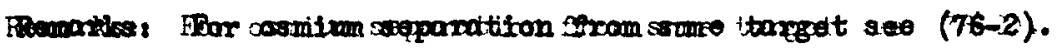


CHEITCAL SEPARATIORS

Element soparated: Platinum

Iarget terial: Pt, Ir, Au, Hg

Type of bbdt: $60^{\prime \prime}, 184$ " bombardments
Prooodure by: Wilkinson, Hicks

Time for sep'n: $1 \mathrm{hr},-4 \mathrm{hrs}$.

Equipment required: sop. funnel

Yiold: $n$ 100\%

Degree of purification: Deçontaminates vell from Au, Ir, \& Hg

Adrantages: Carrier free Pt oan be obtained pure.

\section{Procedure:}

(1) Dissolve targets (exoept $\mathrm{Ir}$ ) in $\mathrm{HCl}$ with minimum of $\mathrm{HNO}_{3}$. (For Ir see $77-1$ ).

(2) Add $\mathrm{Au}, \mathrm{B}_{\mathrm{C}}$, Pt \& Ir carriers as needed. Extract the solution with at loast cqual volume ethyl acetato twioe to get rid of Au (chloride concentration need only be above $1 \mathrm{~N}$ ), with gold added for the second extraction.

(3) Destroy all nitrate with hydroxylamine, or hydrazine, then add 0.1 gm. $\mathrm{SnCl}_{2}$. Centrifuge out any ppt $\left(\mathrm{HE}_{2} \mathrm{Cl}_{2}\right)$. The red color is $\mathrm{PtCl}_{4}$ which is extracted into thyl scetate.

(4) Organic layer is mashed twice with equal rolume $6 \mathrm{H} \mathrm{HCl,} \mathrm{then}$ evaporated to dryness.

(5) Residue is taken up in $2 \mathrm{~N} \mathrm{HCl}$, Pt metal is precipitated with magnesium metal in form or powder or dust. (Don't use $\mathrm{Zn}$ since forms slow dis solving sponge.)

Remarks: Soe G. rilltinson, Phys. Rev., 73, 252 (1948). Also soe G. Willinson, Phys. Rev. 75, 1019 (1949).

\section{$6 / 25 / 49$}

$P=18-17$ 
CHELICALI SEPARETIONS.

Element separated: Platinum

Target material: Iridium foil

Type of bbat: 184" protons (any energy)

\author{
Procedure by: Thompson \& \\ Rasmusson \\ Time for sep'n: $1 / 2 \mathrm{hr}$. \\ Equipment requirad: \\ small porcelain cruciblo \\ transfer pipettes \\ contrifuge tubo
}

Yiold: $\sim 70 \%$ depending upon stop (3)

Dogrue of purification: at least factor of 100

Advantages: A simple, roasonably fast procedure for solution and soparation with a targot metal (Ir) extromely rosistant to dissolution in aqua recia.

Procedure:

(1) bke a molt of $\mathrm{KOH}$ and $\mathrm{KNO}_{3}(\sim 50-50$, not critical) in a small porcelain curcibla, heating strongly over a Fisher burner.

(2) To this hot flux add the target Ir motal, continuing to hont (and adding KOH if volume of flux gots too small) until the metal is oompletely dissolved. (for a small strip of 1 mil foil this should take no longer than 5-10 min.)

(3) Allar flux to cool, then leach for $\sim 5$ min. with conc. ICl, adding $A u$ and $2 t$ carriors in small amount. (Ir gives strong blue colored sol'n)

(4) Extract twice with cthyl acetate to remove Av.

(5) Add a littlo $\mathrm{SnCl}_{2}$ solution in $\mathrm{HCl}$ to the aqueous phase until a dark red coloration $\left(\mathrm{H}_{2} \mathrm{PtCl}_{4}\right.$ ) indioates the reduotion of $\mathrm{Pt}$ from +4 to +2 state is complo to (see romarks.)

(6) Extract the red coloration (Pt) into ethyl acctate. Wash organic layer trico with equal volume of $3 \mathrm{~N} \mathrm{HCl}$.

(7) Plate organic layer \& flame.

Romarks :

As most Ir foll contains about in $1 \%$ Pt inpurity, it is woll to provido a step for extraction of Au activities, whether or not the $A u$ is dosired for loter work, even if it is simply a proton bombarded Ir.

On $\mathrm{SnCl}$, rodustion the strong blue coloration of $\operatorname{Ir}(+6 ?)$ disappoars, pormitting the red of reducod $\mathrm{H}_{2} \mathrm{PtCl}_{4}$ to bo scon. 


\section{8-2 (расо 2)}

By spending more time leachine the molt in (3) and by using several portions of leaching agent the chomioal yields might be made almost quanti tative.

For Au sop'n from same target sce (79-4).

For Ir sep'n from same target sco (77-2).

II if present should bo checked for interferenoe with this procodure.

\section{$7 / 27 / 49$}

P-18-116 
Elcmont scparatcd: Pletinum

Targot matcrial: Uranium motal ( 21 )

Typo of bbdt: 388 Hov alphas
Procoduro by: Molfo

Timo for scp'n: $\sim 1$ 1/2 dnys whon scparated with Ir \& Rh.

Equipmont roquirod: Spocinl distilling flask, contrifugo, sop. funnols, standard

Yiold: $\sim 5 \%$

Degreo of purificntion: At least $10^{4}$ from all fission products. No impuritios dotcoted in radioactivitics.

Proceduro:

(1) Cut out the central portion of tho targot and boil with concontrated $\mathrm{HCl}$ to dissolvo it and to expel GC.

(2) Add $5 \mathrm{mg} \mathrm{I}^{-}$and $\mathrm{IO}_{3}{ }^{-}$and boil the solution again to expel iodine.

(3) Add $2 C \mathrm{mg} O s, \mathrm{Ir}, \mathrm{Pt}$, and $\mathrm{Au}$ carricrs plus $20 \mathrm{mg} \mathrm{Ba}, \mathrm{Ru}, \mathrm{Rh}$ and $P d$ carriors. Fithdrav a 20\% aliquot for lator dotcrminations of $\mathrm{Ba}, \mathrm{Ru}$ and $\mathrm{Rh}$.

(4) Plaoo the rumaining solution in a spccial sll-glass distilling flask having a thistlo tubo ontry and an air cntry. Add conocntratod $\mathrm{HHO}_{3}$ through tho thistlo tubo, and distill $0 \mathrm{SO}_{4}$ into $6 \mathrm{M} \mathrm{NaOH}$ in an loo bath. (Savo for os dotormination (76-1)).

(5) Plrco the residuo from the 0 s distillation in a boakor, add $10 \mathrm{ml}$ $70 \% \mathrm{HClO}_{4}$ and boil tho solution to fumos of $\mathrm{HClO}_{4}$ to oxpel $\mathrm{Ru}$.

(6) Dilute the solution, add $5 \mathrm{mg}$ morc $\mathrm{ku}$ carrior, and $5 \mathrm{mg}$ moro $\mathrm{I}^{-}$and $\mathrm{IO}_{3}{ }^{-}$and repont the fuming.

(7) Add onc ml dilute HCl, dilute tho solution to 4 N and oxtraot trioc with cqual volume butyl acctnto to docontaminato from $\mathrm{Hg}$ and from Au.

(8) Diluto the solution to $0.5 \mathrm{~N}$ in $\mathrm{H}^{+}$, add $5 \mathrm{ml}$ dimothylglyoximo solution ( $1 \%$ in aloohol) and Filtor off tho palladiun ppt.

(9) Add cono HCl to supn to mako $\sim 5 \mathrm{~N}$. Add $\mathrm{SnCl}_{2}$ dropwiso until tho chorryred of $\mathrm{Pt}^{++}$is apparcnt.

(10) Bxtract the Pt with throc equal portions of butyl acctato.

(11) Trash the platinum out of the organic layer with 6 I R.OH, aoidify to $5 \mathrm{~N} \mathrm{KCl}$ and rooxtract into butyl acotatc. Ropont cyolc.

(12) Wash Pt from organic layor into $6 \mathrm{KN}$ MoH and ppt PtS from this alkaline solution gradually aoidifiod to $6 \mathrm{H}$.

(13) Dissolvo tho sulfide ppt in aque rogia, wako alkalinc and soavongo 
twioo with 5 me pptns of $\mathrm{La}(\mathrm{OH})_{3}$.

(14) Buffor tho supn with acotito and scavongo throo timos with $1 \mathrm{mg}$ pptns of Mo and Pd with 8-hydroxy quinolino.

(15) Inko solution aoid and ppt platinum motal with powdored magnosium. Fivigh tho motal to detormine chomioal yiold and plate.

\section{Romarks :}

Rh, Ir and Pt should bo soparated from ono bombardmont laarine $0 s$, Ru and Pa for a socond bombardmont unloss several pooplo aro oooporrting on the procoduro.

The yiold of activity of $\mathrm{Os}$, Ir, and Pt is vory low in comparison with that of tho other platinum metals and many other fission products formod in the bombardmont. This faot nooossitatos, for Ir and Pt, rigorous and repectod decontamination procoduros which rosult in low ohomicol yiolds.

For othor platinum motal-fission product soparations sco: ·

Iridium: $77-3$

Osmium: $76-1$

Ruthonium: 44-2

Rhodium; 45-1

Palladium; 46-5

\section{$8 / 16 / 49$}


$79-1$

CABHICAL SEPARATIONS

Element separatod: Gold

Procedure by: Wilkinson, Hicks

Target material: Pt, Ir, Hg, Au

Time for sep'n: $1 / 2 \mathrm{hr}-4 \mathrm{hrs}$.

Typo of bbdt: $60^{\prime \prime}$ or 184" oyclotron

Equipment required: sep.

funnel

Yield: $\backsim 100 \%$

Dogreo of purification: Decontaminates well from Pt, Ir \& H6.

Adrantages, Carrior freo Au oan bo obtained pure within 15-20 min, after solution of target.

Procodure:

(1) Dissolvo Pt, Au, or Hg in aqua regia. To dissolvo Ir metal: (seo 77-1).

( $\mathrm{AuCl}_{3}$ oarrier may be added here)

(2) Chloride ion must be greater than $6 \mathrm{~N}$ (Hg extracts), and the solution shaken with an equal volume of $\bar{\theta}$ thyl aoctate (gold in organic layer) and layors separated.

(3) Pash ethyl acotate layer twioe wi th equal volume 6 N HCl.

(4) Evaporate othyl acetato layor to dryness \& take up residuc in I N HCl.

(5) Bubblo in $\mathrm{SO}_{2}$ to reduce $\mathrm{Au}^{+3}$ to $\mathrm{Au}$ in the hot.

Rema rics: Soe: G. Filleinson, Phys. Rov, 73, 252 (1948)

Seo also: G. Milkinson, Phys. Rev. 75, 1019 (1949)

$6 / 25 / 49$

P-18 -26 


\section{CHEMTCAL SEPARATIONS}

Element separated: Gold

Target material: Tracer mercury

Type of bbdt: lillking experiment

Yield: Can be quantitative if several extractions made.

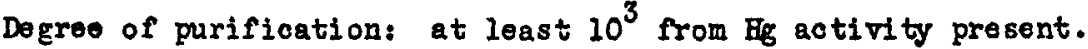

Proceriure:

(1) Talee $\mathrm{Hg}$ tracer in $4 \mathrm{ml}$ of $\mathrm{G} 3 \mathrm{~N} \mathrm{ECl}$ and extract with 500 hof isoamy aoetate. (The presence of at least $0.1 \mathrm{~N} \mathrm{CI}$ is required for a sepn from Hg.) - Au into the organic layer.

(2) Fash the organic layer with equal volume sat $\mathrm{NH}_{4} \mathrm{Cl}$ sol'n to insure sep'n from Hg.

(3) Plate organio layer for Alu samplo. 
Element separated: Cold (quick procedure)

Target matorial: Cold in leaf form (.004 mil)

Type of bbdt: 184" High energy protons.

\author{
Procedure by: Thompson \& \\ Resmussen \\ Tims for sep'n: 4-10 min. \\ Equipment required: \\ Centrifuge tube. Mitoro- \\ pipettes
}

Yield: $\operatorname{100\% }$

Dagree of purification: Adequate separation from Hg and spallation products, at least fretor of 50 .

Advantages: Extreme speed and simplicity combined with reasonable purification.

Prooedure:

(1) Dissolvo Au in warm $6 \mathrm{H}$ aqua rogia (2N $\mathrm{HNO}_{3}, 4 \mathrm{II} H \mathrm{H}$ ) in contrifugo tube. Work in small $\overrightarrow{\text { wolume }}(1-2 \mathrm{ml} .)^{-2}$

(2) Ada hold-back carriers for Hg, Pt, Ir, and Os (nl mg each).

(3) Add (1 to $1 / 2 \mathrm{ml}$.) ethyl aootate. Agitate, mixing phases $\mathrm{mith}$ transfer pipotte. (Yellow color of gold quantitatively extracts into organic phase.)

(4) Tash the separated ethyl acetate phase once or twice with 6 II aqua repia. (Any rash of high chloride conoentration serves to remove $\mathrm{Hg}$, although $\mathrm{TI}$ if present may not be entirely washod out.)

(5) The solution of Au in ethyl acetate may now be rapidly evaporated on a plate for counting or subjected to further specific gold chemistry.

Remarks: A further procedure of very specific gold chemistry, acoording to Plikinson, but of loizer yield $450 \%$ is as follows: Preoipitation of $\mathrm{Au}$ as the motal by $\mathrm{SO}_{2}$ reduction, bubbling $\mathrm{SO}_{2}$ through a warm $2 \mathrm{~N} \mathrm{HMO}_{3}$ solution of the dissolved gold. 2 The ppted $A$ u can be rodissolved in aqua regia s extracted with othyl acetate for counting.

Getting the Au from ethyl acetate into 2 If Ha: proliminary to the $\mathrm{SO}_{2}$ ppt'n can be done in several ways, such as, (a) evaporation of ethyl aoetate - Au sol'n (Use hot place for ethyl aceta is flammable) and taking residue up with $2_{\text {il }} \mathrm{ErO}_{3}$, or (b) adding 1 I $10 \mathrm{H}$ to ethyl aceta te Au 80 ' $^{\prime} \mathrm{n}$, taking $A u$ baok into aqueous phase (and also introducing loss by formation of some insoluble Au oxide), then separatinf: the phases and making the aqueous about $2 \mathbb{E}$ acid by ading $\mathrm{IMO}_{3}$. 
Elemont separated: Gold

Target material: Iridium foil

Typo of bbdt: 184" (any encrgy)

Y1cld: $\sim 70 \%$, doponding on leach

Degroo of purification: at loast 100

Advantagos: A simplo, roasonably fast proceduro for solution and soparation with a target motal (Ir) axtremoly resistant to dissolution in aqua regia.

Procedurc:

(1) Wako a melt of $\mathrm{KOH}$ and $\mathrm{KNO}_{3}$ ( $($ 50-50, not critioal) in a small porcolain orucible, hoatine strongly over a Fishor burner.

(2) To this hot flux add tho target Ir motal, continuing to heat (and adding KOH if volumo of flux gets too small) until the motal is completely dissolvod. (for a small strip of 1 mil foil this should take no longer than $5-10$ min.)

(3) Allow flux to cool, then loach for $\Omega 5$ min. with cono. HCl, adding Au and Pt carricrs in small amount. (Ir gives strone bluc colored $\operatorname{sol} \mathrm{in}$ )

(4) Extract twice with ethyl acotate to romove Au.

(5) Combine organic layers and wash twice with equal voluno $3 \mathrm{~N} H C I$.

(6) Plato organic layer and Name.

Remarks :

As most Ir foil contalas about $n 1 \%$ Pt impurity, it is well to provide a stop for extraction of Au activitios, whether or not the du is dosirod for later work, oven if it is simply a proton bombarded Ir.

On $\mathrm{SnCl}_{2}$ roduction the strong bluo coloration of $\operatorname{Ir}(+6 ?)$ disappears, permitting the rod of reduced $\mathrm{H}_{2} \mathrm{PtCl}_{4}$ to bo secn.

By spending more time leaching the molt in (3) and by using several portions of leaching agent the ohemical yielde might bo made almost quantitativo.

For Ir sop'n from samo target see $(77-2)$.

For Pt sep'n from same target see (78-2).

TI if prosent should be chooked for intorforonoo with this procoduro. 
Element separated: lieroury

Target material: Platinium

Type of bbdt: $65 \mathrm{lev}$ a-particles for 3 hours
Procedure by: R. V. Fink i D. G. Jarraloer

TIme for sep'n: 60 minutes

Equipment required: Standard

Yiold: $\sim 70 \%$

Degreo of purification: Excellent - factor of at least 100 from aotivities present.

Procedure:

(1) Pt tares dissolved in $4 \mathrm{cc}$ agua rogia in a porcolain oruc1ble. $50 \mathrm{u}$ E. Au and He carriors added. Sol'n ovaporated to expoll $\mathrm{HWO}_{3}$.

(2) Extracted 5 times rith $1 / 5$ volume of isonmyl acotate in prosenco of at least $0.1-\mathrm{N} \mathrm{BCl}$. The isoanyl acetate layer contains gold free from meroury.

(3) The aqueous layer has exoess $\mathrm{SnCl}_{2}$ added to $\mathrm{ppt} \mathrm{Hg}_{2} \mathrm{Cl}_{2}$. The $\mathrm{Pt}$ is roducod to a beautiful red $\mathrm{Pt}^{++}$oolor. The ppt $1 \mathrm{~s}$ washed until froo of this oolor.

(4) The ppt is dissolved in dil. anue regia and used as the morcury fraction.

Remarks: (a) Reoyoling will improre purity, although this mothod has been shown to give excel lent radiochemical purity.

$7 / 14 / 49$ 


\section{CHEHICAL SEPARATIONS}

Elomont separated: Neroury

Procedure by: R. W. PInk

Targot matorial: Gold

Time for sep'n: 70 min.

Type of bbdt: 60 liev protons

Equipment required: Standard

Yield: Near 80-90\%

Degree of purification: Exoellent - factor of 100 from activities present.

\section{Prooedure:}

(1) The cold target is dissolved by heating in 4 oc hot, oono. aqua regia. Pt and $\mathrm{H}_{\mathrm{b}}$ carrier $(50 \mathrm{LE})$ are added. Five or more extraotions with isoamylacetate, 3 oo each portion are made. The Gold will be found in the organio layer.

(2) The aqueous layor is boiled to near drymess with conc. HCl to expell $\mathrm{HrO}_{3}$, and excess $\mathrm{SnCl}_{2}$ added to ppt. $\mathrm{H}_{2} \mathrm{Cl}_{2}$, vhich 18 then washed until freo from red Pt color.

(3) The $\mathrm{Hg}_{2} \mathrm{Cl}_{2}$ ppt is then redissolved in 2 co dil, aqua regia, and used as the mercury frootion.

Rema rks:

(a) The 1soamyl acetate extraction of gold from mercury is quantitative in presence of $0.1 \mathrm{~N}$ or more ohloride. This is the mothod used to milk gold daughters from the woroury fraction.

$7 / 12 / 49$

$P-18-49$ 
CHEMICAL SEPARA TIONS

Element separated: Nercury

Target material: cold or platinum

Type of bbdt: Protons on gold or a-particles on $\mathrm{Pt}$, but not vice versa
Procedure by: R.\%. Finle \&

S. G. Thompson

Time for sep'n: from 1 to 5 min.

Equipment required: mercury volatilizer (see astatine boiler)

Yteld: Enough 20 tirity to work with but by no means quantitative. For more yield heat longer.

Degree of purifioation: Extremoly pure.

Advantazes: For short He half-lives when quick samples are desired for counting. Definitive purity.

Procedure :

(1) The tarcet is introduoed into the chamber of the Mercury vaporizer. A thin Pt collecting plate is put on the bottom of the water-cooled cold-finger with duco cement.

(2) The $\mathrm{Hg}$ is then vaporized by a bunsen flame, and is collected in high speoifio activity on tire plate.

Remarka :

(a) Caution must be exeroised not to open the vaporizer until it has thoroughly cooled, lest the hands become covered with unwashable meroury eotivity whioh spews forth when the veporizer is hot.

(b) The vapor pressure of $\mathrm{Hg}$ at only $400^{\circ} \mathrm{C}$ is $1574.1 \mathrm{~mm}$ of $\mathrm{Hg}$, over $2 \mathrm{~atm} . ;$ while that of molten pold at $1292^{\circ} \mathrm{C}$ is only $0.001 \mathrm{~mm}$. Hence, at $1000^{\circ} \mathbf{K}$, a complete separation is attained.

Tl if present will follow the $\mathrm{H}_{\mathrm{g}}$ in this procedure

$7 / 12 / 49$

P.18-55 


\section{CHEIICAL SEYPARATIOMS}

Element separateds Weroury

Targot merial: Au

Type of bbdt: Weut ron captare in pile

\author{
Prooedure by: Prohaska \\ Timo for sep'ns Two or more \\ days
}

Equipmont roquired: separatory funnels, + ordinary beakers, flask, to.

Yiold: ? probably $60-80 \%$

Degree of purifioation: $\sim 95-98 \%$

Advantages: VIll separate 5-10 mg of Hg from $100 \mathrm{~g}$ of Au.

Prooodure:

(1) Dissolvo sample (assume $100 \mathrm{gms}$ of $\mathrm{Au}$ ) in $250 \mathrm{ml}$ hot cono. $\mathrm{HCl}$ and minimum $\mathrm{BNO}_{3}$ under (air oooled) reflux condenser.

(2) Then sample completely dissolved, dilute to $500 \mathrm{ml}$ (approx $6 \mathrm{us}^{+}$). Extract with four suocessive $200 \mathrm{ml}$ portions of other.

(3) Add $\mathrm{NaOH}$ to $\mathrm{H}_{2} \mathrm{O}$ portion until $\mathrm{pH} \approx 2$. Add $\mathrm{H}_{2} \mathrm{~S}$ and $\mathrm{ppt} \mathrm{Au}_{2} \mathrm{~S}_{3}+\mathrm{HgS}$. Centrifuge.

(4) Dissolve HeS + $\mathrm{Au}_{2} \mathrm{~S}_{3}$ in (minimum) $6 \mathrm{IICl}+$ drons cono. $\mathrm{HNO}_{3}$, volume of solution should be less than $100 \mathrm{ml}$ at this point."

(5) Extract with suocessive $50 \mathrm{ml}$ portions of ether until no yellow oolor of $\mathrm{AuCl}_{4}{ }^{-}$observable in $\mathrm{B}_{2} \mathrm{O}$ portion.

(6) Extract with 2 additional $50 \mathrm{ml}$ portions of $\theta$ ther.

(7) Again reduce $\mathrm{pH}$ to $\cong_{1}$ with $\mathrm{NaOH}$ and ppt HgS with $\mathrm{H}_{2} \mathrm{~s}$.

(8) Repeat the solution and extraction procodure.

Remarks :

In the three other extractions, an estimated $20 \%-30 \%$ of the $\mathrm{BgCl}$

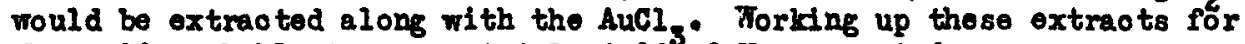
Hf rould probably inerease total yield of Ho separated.

It appears doubtful that purity of $\mathrm{Bg}$ reported would be inoreased by fur ther solution and extraotion.

$8 / 24 / 49$

$P-18-260$ 
CHEMICAL SEPARATIONS

Element separated: Thallium

Target material: $\mathrm{HgNO}_{3}$

Type of bbdt: Linao 2 min. of 30 lev protons
Prooedure by: Brooks

Time for sep'n: 5 min.

Equipment required: 4000 test tube

Yieid: $20 \%$

Degreo of purification: good

Advantages: Fast -

Prooeduro:

(1) Dis solve target in 20 oo sat. KI (hot)

(2) Add 2 oo of $\mathrm{H}_{2} \mathrm{O}$ containing $20 \mathrm{mg} \mathrm{TI} \mathrm{NO}_{3}$. Shake well.

(3) Pour off H耳 $_{4}=801 \mathrm{ln}$, dry ppt and oount.

Remarks: HgHO docomposes somenhat oron in 2 min. bombardmont. Donit use it in a oyclotronl Tho Linuo targots are not in a vacuam.

$6 / 16 / 49$ 


$$
81-2
$$

\section{GIEMTCAL SIPARATIORS}

Elemeat separated: Thallium

Prooedure by: Orth \& lloinke

Target material: cold foil

Time for sep'n: $\sim 30$ min.

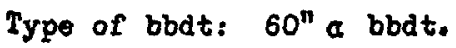

Equipment required: Standard

Yield: $\sim 90 \%$

Degree of purifioation: At least factor of 10 from other activities present.

\section{Procedure:}

(1) Dissolre Au target in aqua regia $\left(1: 9 \mathrm{HNO}_{3}\right.$ to $\mathrm{HCl}$ ) add (5 mF. $\mathrm{Tl}^{+}$ ourrior and $5 \mathrm{mg} \mathrm{Hg}^{++}$oarrier.

(2) Add $\mathrm{NH}_{2} \mathrm{OH} \cdot \mathrm{HCl}$, ppt $\mathrm{Au}$ motal to reduce to $\mathrm{Hg}_{2}{ }^{++}, \mathrm{II}^{+}$.

(3) Neutralise with $\mathrm{Na}_{2} \mathrm{CO}_{3}$ (boop cooli) ppt $\mathrm{Hg}_{2} \mathrm{CO}_{3}$.

(4) To sup'n add sat. soln of II or few drops of HI, preoipitating III.

Remarks: The $30 \%$ yield can readily be obtained if the Il id plated from the sol'n of (3). If the TI is ppt as TII yield may be only rs $75 x$.

$7 / 12 / 49$

P $-18-48$ 
Element separated: Thallium

Parent material: Lead

Malking experiment

Yield: $\sim 96 \%$

Degreo of purifioation: $<0.01 \%$ Po contamination

Advantages: Extrem ly good PO-TI separation

Procedure:

(1) $\mathrm{Pb}$ to be milked kept in $10 \mathrm{ml}$ of $6 \mathrm{~N}$ HCl solution. T1 carrier may be added if desired, but is not necessary. Add 3 or 4 drops of $\mathrm{nmo}_{4}$ solution to insure oxidation of $\mathrm{Tl}$ to $\mathrm{TI}^{+++}$Stir solution until Ioss of brown oolor.

(2) Add $10 \mathrm{ml}$ of $\mathrm{ECl}$ saturated diethyl ether. (The ether oan be convensently prepared by shaking with conc. $\mathrm{HCl}$ and allowing the two layers to stand in contact until ether is neoded). Stir about 3 min. Centrifuge. Bemove ether layer containing the $M^{\text {tif }}$.

(3) Extract a second timo by same wethod. Combine ether layers.

(4) Wash ether with $10 \mathrm{ml}$ portion of $6 \mathrm{NHCl}$. Centrifuge. Transfor ether to new tube.

(5) Eveporate ether with jet of air to convenient rolume. If entire sample is to be counted, the remining ether oan be ovaporated on counting plate. If only an aliquot is desired, evaporate to drymess and take up residue in desired volums of water. Addition of a drop $\mathrm{HHO}_{3}$ and heatin will help in obtaining complete solution.

Remerks :

$\mathrm{M}^{+}$does not extract. Adaltion of $\mathrm{MMO}_{4}$ to insure oxidation to $\mathrm{MI}^{+++}$
is important.

Since the time for separation is quite long for a milking procedure, the steps prior to ifmal separation should be done at the same relativo time intervals in each milking.

Two extractions givo $>99 \%$ yield. The washing with BCl repgres $\sim 4 \%$ of TI. The overall yield of $\mathrm{Tl}$ is reproducible. $3 \mathrm{gr} \mathrm{P}^{20}$ can be used conveniently as a traoer to determino chemical yield. 


\author{
Element separated: Lead \\ Procedure by: Karraker \\ Target material: Thallium \\ Timo for sep'n: in 1 hour \\ Type of bbdt: 60-80 Lev $\mathrm{D}^{+}$or $\mathrm{H}^{+}$ \\ Equipment required: No \\ speoial equipment \\ Yield: n $95 \%$ \\ Degree of purification: Good, fuctor of at least 100. \\ Advantages, One-step is usually suffioient purification.
}

\title{
Procedure:
}

(1) Dissolve $\mathrm{Il}$ target in $6 \mathrm{MH} \mathrm{HO}_{4}$ the smallest amount possible. Add 5 mg $\mathrm{Pb}$ carrier, also $5^{2} \mathrm{mg}^{4} \mathrm{HE}$ carrier as hold-back.

(2) Evaporate solution over a hot plate, with an air-jet blowing on the top of the solution, till fumes of $\mathrm{SO}_{2}$ appear and the solution is quite concentrated.

(3) Dilute carefully with 2 volumes of $\mathrm{H}_{2} \mathrm{O}$. $\mathrm{PbSO}_{4}$, white fpt, appears. Wash ppt with 2 $\mathrm{H}_{2} \mathrm{SO}_{4}$, then with $\mathrm{H}_{2}^{2} \mathrm{O}$. If desirod, this may be dis8olved in $\mathrm{XH}_{4} \overline{\mathrm{I}}_{3} \mathrm{and}^{4}$ reppted as $\mathrm{PbCrO}_{4}$. However, it is usually sufficiently pufe without further steps?

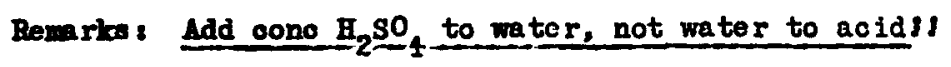

$7 / 14 / 49$ 


\begin{abstract}
Elomont soparatod: Lead
Paront matorinl: Bismuth (20 mg or loss carrier)
\end{abstract}

Mlking experimont

Yiold: $\sim 85 \%$

Dogroc of purlfioation: $<0.05 \%$ Bi contrunination

Procodurc:

Bi purifiod, final stop boing preoipitation as Biocl (obtainablo by method listed in steps 1-3.) (Can dissolve Bi from 11 foil of 83-1 and procood with BlOCl pptn and step (I) belom.)

(1) Dissolvo in $\mathrm{far}$ drops cono. HwO . Add 10 mg $\mathrm{Pb}$ carricr (preforably $\mathrm{Pb}\left(\mathrm{NO}_{3}\right)_{2}$. Add 3 drops cone. HCl. Dilute to $\sim 8 \mathrm{ml}$.

(2) Add $\mathrm{NH}_{3}$ dropwiso until pormanont prooipitato just forms, and thon $\mathrm{HWO}_{3}$ dropwiso until solution just clears.

(3) At dosired time for milking diluto to $45 \mathrm{ml}$ and hoat in wator bath for a fow minutos. Fino orystals of BiOCl should form. Contrifugo, and rotain $B i O C l$ for futuro milkings.

(4) To tho supornatont add a drop of $\mathrm{MH}_{3}$. If the solution romains oloar you havo obtained a good separation.

(5) hdd 2-3 ml of $\mathrm{Na}_{2} \mathrm{Cr}_{2} \mathrm{O}_{7}$ solution to causo prooipitation of $\mathrm{PbCrO}_{4}$. contrifugo, and disóafd supornatent.

(6) Dissolvo PbCrO, by addition of $2 \mathrm{ml} 4 \mathrm{~N}$ HCl and ono drop $30 \%$ $\mathrm{H}_{2} \mathrm{O}_{2}$. Hoat in wator bath to dostroy exposs $\mathrm{H}_{2} \mathrm{O}_{2}$.

(7) Add $20 \mathrm{mg}$ inactivo Bi carrior and ropeat BiOCl soparntion by abovo mothods. Ropeat prcoipitation of $\mathrm{PbCrO}_{4}$.

(8) Dissolvo $\mathrm{FbCrO}_{4}$ as in stop (6).

(9) Diluto to any dosired volum and mount aliquots for counting. Tho rcsults aro reproducible, and chomical yiold detorminations aro not nocossary. If tho lattor arc desired, procood with oto 10 :

(10) Add $5 \mathrm{ml}$ cone $\mathrm{H}_{2} \mathrm{SO}_{4}$. Evaporato to fumes of $\mathrm{SO}_{3}$. Rosulting volumo will bo $2-3 \mathrm{ml}$. Cóol. Diluto carofully to $280 \mathrm{ml}$. Cool. Filtor, dry, and weigh $\mathrm{PbSO}_{4}$. 
Roma riss :

Any singlo prooipitation of $B 1 O C_{1}$ under theso conditions gitos a yicld of 98-99\% $\mathrm{Bi}$, with $8 \%$ of the $\mathrm{Pb}$ retainod with the $\mathrm{Bi}$. Ono $\mathrm{BI}$ senvenge of the separntod $\mathrm{Pb}$ should bo sufficiont purification from the paront.

In calculating the life of the paront from consecutito milkings of the samo Bi solution correction should bo mado for the $3 \%$ of the daughter retainod with the parcnt.

Purification of $\mathrm{Pb}$ as $\mathrm{PbSO}_{4}$ gives varying yiolds, and dotermination of chomical yiold by woighing is nocossary.

Thore the $\mathrm{Pb}$ fraotions will bo furthor milked for Tl (81-3) stop at stop (8). 
CHEIICAL SFPARATIONS

Elcmont soparatod: Icad

Paront matorial: Polonium

Lliking Experimont

Yald: 95-100\%

Dogroo of purification: faotor of $10^{6}$ from po with two washos.

Procodurc:

Po is in $20 \%$ tributyl phosphato in dibutyl other mixturo. To milk solution:

(1) Extract with oqual volume of $6 \mathrm{M} \mathrm{HCl.} \mathrm{B1} \mathrm{\&} \mathrm{PO} 80$ into wator phaso.

(2) Fash HCl oxtraot twiloo with $1 / 10$ its volume of tributyl phosphato solvont. Add the first portion to the po sol'n, thon discard 2 nd portion.

(3) Add $1 / 2$ mg $B 1$ and $1 / 2$ mg Pb carricr, (pptn mado from 4 ce volumos.)

(4) To separato $B 1$ and $\mathrm{Pb}$, the proooduro is almost identical with that of Noumann. (82-2).

(5) Thallium daughters of tize PU may bo separatod by oxidation and oxtraction with othor. (81-3). 
Eloment separated: Bismuth

Target terial: $\mathrm{Pb}$

Type of bbdt: protons or deuterons 184 " or $60^{\prime \prime}$
Procedure by: Noumann

Time for sep'n: 15 min from solution of target up to plating stop

Equipment required: no special equipment

Yield: see remariss

Degree of purification: Good separation from $\mathrm{Pb}$ and II at least factor of $10^{4}$. Interference from noble metals.

Advantages; Rapid separation when looking for short half-lives. Prepares carrierless samples for pulse analysis, or high speoific aotivity samples for mass speotrograph or frray spectrometer.

Prooodure,

(1) Dissolvo $\mathrm{Pb}$ target in $6 \mathrm{~N} \mathrm{HNO}_{3}$. Koop volumo as small as poseiblo. Add water if nocessary to give complete solution.

(2) Add $8 \mathrm{~N}$ WOH dropwise until formation of $\mathrm{Pb}(\mathrm{OH})_{2} \cdot$ Add HNO 3 dropwise until solution just olears.

(3) Place $\mathrm{H}_{1}$ foil in solution. Bi will electrochemioally replace $\mathrm{H}_{1}$ on foil. Koep solution warm, and stir oontinuously to obtain highest yiolds. See remarks.

(4) a counting and pulse analys is can be done direotly from Ni foil after washing well and drying. Ni foil should be givon protective ooating (label shollao is satisfactory) on one side so that activity plates on only the unprotected side.

(6) To prepare sample for mass spectrograph or $\beta$-ray spoctrometer, remove $\mathrm{HI}_{1}$ foil from solution when desired amount of aotivity is obtained and wash well. Dis solve $\mathrm{HI}_{1}$ foll in $\mathrm{HrO}_{3}$. Add $50 \mathrm{p}$ grams $\mathrm{BI}$ oarrier and $20 \mathrm{mg}$ La oarrier. Preolpitate $\left.\mathrm{La}_{3} \mathrm{OH}\right)_{3}$ and $\mathrm{BI}(\mathrm{OH})_{3}$ by addition of $\mathrm{NH}_{3}$. Wash prooipitato with water and 1 drop $\mathrm{NH}_{3}$. Dissolvo in few diops $\mathrm{ECl}$, dilute to $0.3 \mathrm{I} \mathrm{HCl,} \mathrm{and} \mathrm{pass} \mathrm{H} S$ into solution. Bis $\mathrm{S}_{3}$ procipitates. Furtier disposition of sample depends on type of mounting nocessary for instrument.

Remarks As a rough indication of yiolds to be expected, a volume of $\sim 40 \mathrm{ml}$, heated to $\sim 85^{\circ} \mathrm{C}$, and stirred slowly with moohaniosi stirrer gives these yielde at various time intervals, 5 Min. $10 \%$; 15 min. $25 \%$; 45 min. 65\%.

This prooedure does not give separation from motals more easily reduoed than B1. Among spallation product impuritios will be Au, Bg, and Pt motals. Among flssion product impurities will be Cu, Ag, Pt motals, and $\mathrm{Sb}$. Separation from Po rill also not be made if it is produoed in bombardmont. 
CHEMTCL.L SIPLRATIONS

Elomont soparated: Bismuth

Faront matorial: Polonium

liflking oxporimont

Y101d: $95-100 \%$

Dogroe of purification: Factor of $10^{6}$ from Po with two washos
Procodurc by: Karrakor

Timo for sopin: 5 min.

Equipmont roquirod: Standard

Procoduro:

Polonium is in $20 \%$ tributyl phosphato, $80 \%$ dibutyl ethor mixture. To milk solution:

(1) Bxtrnot with equal volumo of $6 \mathrm{IHCl}$. Bi and $\mathrm{Pb}$ go into acid phaso.

(2) Wash HCl oxtract tw100 with $1 / 10$ its volum of tributyl phosphato solvont. Add tho first fortion to the Po soln, disoard tho sccond portions.

(3) Add $1 / 2$ mg $B 1$ and $1 / 2$ mg $P b$ oarrior (pptns mado from $\sim 4$ oc volumcs).

(4) To separato $\mathrm{BI}$ and $\mathrm{Pb}$, the proooduro is almost idontionl with that us od by Noumann $(82-2)$.

(5) Thallium daughtors of the load may be soparated by oxidation and cxtraotion with other $(81-3)$. 


\section{CHEITCAL SEPA IATIONS}

Blement separated: Bismuth

Parent matericl: Tracer $\mathrm{Pa}^{228}$ and daughters

Procedure by: Meinke

iflking experiment

Time for sep'n: ru $1 / 2$ hours

Equipment required:

Contrifuge, stirrers, $\operatorname{tank} \mathrm{B}_{2} \mathrm{~S}$

Yield: $\sim 60 \%$

Decree $\cdots$ purification: Pactor of at least $10^{3}$ from $\mathrm{Pa}$ and at least 100 from ther activities. Factor of at least 5 from $\mathrm{Pb}$.

Disadvantages: Gives a thick plate - rather bed for alpha pulso analysis.

Procedure: Purified tracer Pa in ben one TTA solution (procedure 91-1 with DIPK and TTA extractions only).

(1) Stir organio layer $10 \mathrm{~min}$ with oqual volume $6 \mathrm{~N}$ HCl (daughtor into acid layer - most of $\mathrm{Pa}$ remains with orgañic layer).

(2) Wash the acid layer three times with double volume .4 M TTA in benzene, stirring 5 min each. (Removes Pa).

(3) Dilute acid layer to $\sim 2 N$ and ard $\sim 1 / 2$ mi carrier. Bubble in $\mathrm{H}_{2} \mathrm{~S}$ gas to ppt $\mathrm{Bi}$ and $\mathrm{Pb}$ sulfides. Centrifuge.

(4) Again add $1 / 2$ gi carrier and repeat sulfide pptn. Centrifuge and combine ppts of (3) and (4).

(5) Discolve sulfide ppts in few drops hot cone. HCl. Dilute to at least 1 N acid and reppt sulfides by bubbling in $\mathrm{H}_{2} \mathrm{~S}$. Centrifuge.

(6) Repoat step (5), four timos.

(7) Dissolve sulfide ppt in few drops conc $\mathrm{BC} 1$, dilute to $\sim 600$ and boil to rid solution of $\mathrm{H}_{2} \mathrm{~S}$.

(8) Add $1 \mathrm{mg} \mathrm{Pb}$ carrier and $\mathrm{ppt} \mathrm{PbSO}_{4}$ by adding some $\mathrm{SO}_{4}{ }^{-2}\left(\mathrm{H}_{2} \mathrm{SO}_{4}\right.$, $\left(\mathrm{NH}_{4}\right)_{2} \mathrm{SO}_{4}$, etc.) Discard prepioltate.

(9) Repeat step (8) three times.

(10) Add $\mathrm{H}_{2} \mathrm{~S}$ to supn from last pptn and centrifuge out the $\mathrm{Bi}_{2} \mathrm{~S}_{3}$ formed.

(11) Dis solve the $\mathrm{Bi}_{2} \mathrm{~S}_{3}$ in hot cono. $\mathrm{HCl}$, dilute to known volume and plate aliquot for counting. Caution: Do not flame the $\mathrm{BiCl}_{3}$ plate or much of the activity ma be lost. 
83-3 (page 2)

Remarks :

In step (3) if the noidity is groater than $2 \mathrm{~N}$ the $B_{i}$ will not ppt.

See Proscott and Johnson's Qualitative Chemical Analysis (1933) p 157 for notes on $\mathrm{PbSO}_{4}$.

In some exporiments no $\mathrm{B1^{ \circ } -} \mathrm{Pb}$ sepn is required and the solution of step (7) oan bo plated direotly. 
CHERITCAL SEPARATIONS

Element separated: Polonium

Target terial: Lead

Type of bbdt: 380 liev $\mathrm{He}^{++}$

Yield: $80-90 \%$

Degree of purification: Very good - less than $1 \%$ impurity.

Advantages: Po is separated in a carrier-free state. (1)

Procedure:

(1) Dissolve target in $6 \mathrm{~N} \mathrm{HNO}_{3}$.

(2) Heat over a burner until the solution is evaporated to conc. $\mathrm{HNO}_{3}$ (fumine). $\mathrm{Pb}\left(\mathrm{NO}_{3}\right)_{2}$ ppts and may be centrifuged off. Bxtract twioe with equal volume amyl noetate. This removes $\mathrm{TI}, \mathrm{Hg}, \&$ Au.

(3) Add 1-2 ng Bi \& Tl holdback, then fume with HCl (over a burner) till $\mathrm{HNO}_{3}$ is destroyed. It will be necessary to take the solution down to a very small volume, add about $\mathcal{E}$ or so portions of cone. $\mathrm{HCl}$ to accomplish this. Dilute the solution by adding 2 volumes oi $\mathrm{H}_{2} \mathrm{O}$.

(4) Add $\sim^{1}$ me te carriex. Ppt Te with a few drops of conc $3 n \mathrm{Il}_{2}$ soln. Centringe the Te off. This ppt carries Po and At.

(5) Dissolve Te in 1 drop cono. $\mathrm{HNO}_{3}$, then add $1 / 2$ oc oone. HCl.

(6) Pass in $\mathrm{SO}_{2}$ from tank into sol'n in a hot water-bath. Te ppts, carrying $A$. The sol'n now is about $6 \mathrm{~N}$ in $\mathrm{HCl}$ (constant boiling mixture), and contains the Po.

(7) Centrifuge off $\mathrm{Tc}$. It may he necessary to use Aerosol to coagulaţo or transfer solin to soveral test tubes to climinate Te.

(8) Extract sol'n with an equal volume of $20 ; 0$ tributylphosphate in dibutyl ether. Po coes into the organio layer. rash organic layer twice with $6 \mathrm{~N} \mathrm{HCl}$ to thoroughly decontaminate from $\mathrm{B}_{i}$.

(9) Sample may be prepared by plating a drop of organic sol'n, or by

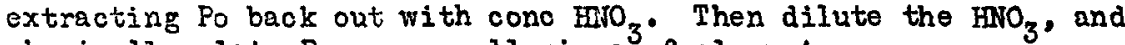
chemically plate Po on a small piece of clean Ag.

Remarks: Step (3) is very slow and tedious, but cannot be avoided, since $P b$ metal can be dissolved only in $\mathrm{HNO}_{3}$. It should be noted the $\mathrm{Pb}$ is almost untouched in conc. $\mathrm{HiO}_{3}$, due to the extreme insolubility of $\mathrm{Pb}\left(\mathrm{NO}_{3}\right)_{2}$ in fuming $\mathrm{FNO}_{3}$. About $60 \%$ of the Po can be chemically plated on $\mathrm{Ag}^{3}$ in $10 \mathrm{~min}$.

$$
7 / 14 / 49
$$

$\mathrm{P}-18-71$ 
Element separated: Polonium

Targot material, Bismuth

Type of bbdt: $180 \mathrm{Hov} \mathrm{D}^{+}$, or $350 \mathrm{heV} \mathrm{\textrm {H } ^ { + }}$
Prooedure by: Karraker

Time for sep'n: 40 min to $1 \mathrm{l} / 2 \mathrm{hrs}$.

Equipment required: Standard

Yield: 80-90\%

Degroe of purification: less than $1 \%$ impurity in sample

Advantages: Po separated in carrier-free state.

\section{Procedure:}

Procedure in general is the same as with Pb, except for inability to ppt Bi as the nitrato. So step (2) in $\mathrm{Pb}$ procoduro is eliminated. It is necessary to dissolvo $\mathrm{BI}$ metal in $\mathrm{HrO}_{3}$, but if $\mathrm{Bi}_{2} \mathrm{O}_{3}$ is used, this can be dissolved in $\mathrm{HCl}$, and neceseity for destroying $\mathrm{BHO}_{3}$ is romoved. This shortens the procodure to whore it can be done as rapidiy as 30 minutes.

See (84-1) for Po sep'n from Pb. 
Eloment soparated: Polonium

lifings from At

Y10ld: $\sim 90 \%$

Degroo of purifioution: At loast faotor of 10
Procoduro by: Barton

Timo for sepin: 40 min.

Equipmont required: tost tubos

Advantagos: Simplioity.

Procodure:

(1) Astatino fraotion dissolvod in 1-5 ml organio solvont (bonzeno, carbon tot., di-isopropyl othor, eto.) (2) Tash with $1 / 2 \mathrm{ml}$ of $2 \mathrm{I} \mathrm{H}_{2} \mathrm{SO}_{4}, 0.25 \mathrm{I} \mathrm{FoSO}{ }_{4}$ soln. (to kecp At in
zero stato.)

(3) Wash $\mathrm{H}_{2} \mathrm{SO}_{4}-\mathrm{FeSO}_{4}$ layer twice with di-isopropyl other.

(4) Extraot the Po from the $\mathrm{H}_{2} \mathrm{SO}_{4}-\mathrm{FoSO}_{4}$ layer with $20 \%$ tributyl phosphate. $80 \%$ dibutyl othor mixture.

(5) Evaporato organic layor on plato with heat lamp. Do not flame or Po will bo lost. 


\section{CHELITCAL SEPARATIONS}

Hloment soparatod: Astatine

Prooodure by: Berton

Targot matorial: $\mathrm{Bi}_{2} \mathrm{O}_{3}(\sim 1 / 2 \mathrm{gm})$
(or thorium metal)

Timo for sepin: 16 min.

Type of bbdt: Any 184" or 60"

Equipment roquirod: Tost tubo

Yield: Unknown, $20 \%$

Degreo of purificatign: Exoollent, from all a omitters formod - at lonst groator than $10^{2}$.

Lidvantages: Simplieity

Procodure:

(1) Dissolve $\mathrm{Bi}_{2} \mathrm{O}_{3}$ sample in $1 / 2-1 \mathrm{ml}$ cono. $\mathrm{HCl}$ or $\mathrm{B}_{2} \mathrm{SO}_{4} \cdot$

(2) Idd small (e $0.5 \mathrm{ml}$ suffioient) amount di-1sopropyl othor, mix, soparate phases.

(3) Plate out organic phasc and count or savo for millangs.

(Uso no more hast than hent lamp or 30 volts on an induotion heator while working vitin the plate or $\Lambda t$ will be lost.)

Romarks:

Step 1. Do not use $\mathrm{HNO}_{3}$ unloss you want a amal1-soale axplosion.

Thorium metal can bo dissolved in gono. $\mathrm{BCl}$ and .01 $\left.\mathrm{N}_{(\mathrm{NH}}\right)_{2} \mathrm{SIF}_{6} \operatorname{soln}$

(Vigorous reaotion onoo startod)! (See 90-4).

See also AICD 1952 (Chemioa). Properties of Astatine; G. L. Johnson, R. F. Leinigor, E. Segrè.)

(1) See Dhys. Rev. 75, 18 (1949). 
Element soparatodi Bmanation

Target matorial: Thorium mal (1 mil)

Typo of bbdt: 184" protons
Prooedure by: Ohiorso, Hinke

Tiw for sepin: 5-15 min.

Equipront requil rod: spocial omation closed sys tom with traps

Yiold: Small from motal, up to $50 \%$ from solutions

Degree of purifiontion: Freo from other a activity - does not soperate from othar rare gases.

Prooedure:

(1) Wotallio otripe of $\mathrm{Th}$ which have boon bombarded with tho full onorgy proton boam aro plaoed in a small olood flask and heated to rod hoat with an induotion hoater for a period of one or two minutos.

(2) Argon carrior is then passed through tho flask and thro ugh a trap coolod with an joo bath.

(3) The carrior and aro thon frosen out in another trap ooolod with a liquid $\mathrm{N}_{2}$ bath.

(4) The activity can be then introduced into sealod counting chambor and counted for a lpha activity.

(6) The aotivity oan bo shown to bo a rare gas by transferring it back and forth from oounter to trap using the liquid $N_{2}$ bath to froese out the activity and oarrior.

Romariko:

The procodure dosoribed is simple but offective in purifying the Fm.. If furthor purifioation is roquirod additional traps may bo usod.

The same typo of apparatus may be usod whon: (a) separating Fn from a solution or (b) milking Bn isotopes from other olomonts, e.g., Fr and At.

Care should be taken to oheck separation from At in theso soparations since in many cases, at least a omall fraotion of tho At presont aots much liko a gas and may pass through the traps. A spooial trap to speoifically remove At may be necessary in somo casos. 
Element separated: Franoium - Blement 87

Target material: Thorium metal foil. Typical target - 3 foi:s $1 / 2^{\prime \prime} \times 1$ 3/4" $x .005^{11}$.

Type of bbdt: $222^{84}$ "bbdt; ith 100 lov protons to make $\mathrm{Fr} 22$ and $\mathrm{Fr}^{23}$. $35 \mathrm{P}_{3}^{\mathrm{MV}}$ proton
Procedure by: Hyde

Time for sep'n: 40 min. 80 min.

Equipment required: contrifugo stirrers $50 \mathrm{ml}$ centrifuge oones

Yield: estimated 10-50\%

Degree of purification: Clean separation from all elemente exoept oesium

Procedure: *

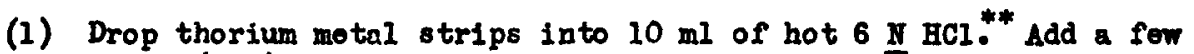
arops $\left(\mathrm{NH}_{4}\right)_{2} \mathrm{SiF}_{6} 801$ in to oloar up blaok rosiduo. Beat with infra-red lámp unt 11 dissolvod. Evaporate down to $5 \mathrm{ml}$ or less.

(2) Transfer to $50 \mathrm{ml}$ centrifuge cone. Cool in ioe bath. Add $15 \mathrm{ml}$ 6 N HCl. Contrifugo off undissolved particles.

(3) To olear supernate ada 4 drope 008 ium oarrier (20 mo C 8/ml) atir and add $1 \mathrm{ml} 1 / 8 \mathrm{M} \mathrm{silicotungstio} \mathrm{aold.} \mathrm{StIr} \mathrm{ocoasionally} 1$ to 4 minutes. Centrifuge down ppt of cesium silicotungstate. Inls preoipitation eliminates $>90 \%$ of total radiation.

(4) Wash ppt twioe with $5 \mathrm{ml} 6 \mathrm{H} \mathrm{HCl}$. From here on can use elther of

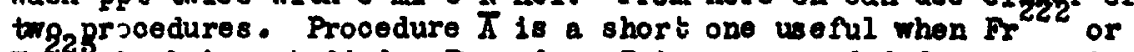
$\mathrm{Fr}^{225}$ is being studied. Prooedure $\mathrm{B}$ is rooommonded for proparing 30 minute $\mathrm{Fr}$

Procedure A - For short-lived franoium 180topes.

(1) A portion of or all of the siliootungetate ppt is eraporated in a small oirole in the center of a platinum plate. This plato is set upon an aluminum plate and oentered above a $1 / 2$ in. hole in this plate. in asbestos washer 18 placed above. On top of the asbestos washer and oovering the hole just above the sample plate 18 placed a seoond platinum diso, scotoh taped to a $1 / 8$ inch aluminum diso. The a luminum disc, platinum disc combination is cooled with a lump of dry ico while an oxygen torch with a small flame is touched to the bottom of the sample plate heating it strongly to red hoat for 5 seoonds. The cooled oolleotor plate then bears a smooth deposit

* This procodure is modeled quite olosely after the fission product procedure for oesium desoribed by Glendenin * Nelson in AECD 2556-C.

** HNO $_{3}$ interfers wh the subsequent pptn of cesium silicotungstate.

For Th sol'n see Phys. Rev. 7518 (1949). 
of cesium as woll as considorablo silich and tungston. ${ }^{* * *}$

(2) This deposit is slurried off the plate with dilute $\mathrm{BC1}$. The silioa and tungsten being insoluble are oontrifuged off. The clear supernate contains the francius and oan be used for ohomioal studios or ovaporated on platinum diso for counting monsuremonts. Usually such samplos are flamed again as described above. The rosulting collector plates are quite oven and oloan of evorything oxcept cesium. The amount of oesium originally added determinos the amount of solid on tho plates.

Proooduro B - For further purification of 30 minute franolum.

(1) Dissolvo silicotungstate ppt in $1 \mathrm{ml}$ of $6 \mathrm{~N} \mathrm{NaOH.} \mathrm{Add} \mathrm{2-3} \mathrm{drops}$ ferric ohloride carrior. (10 mg/ml) stir. Centrifuge down the scavenger $\mathrm{Fe}(\mathrm{OH})_{3}$.

(2) To clear hydroxide supernate in $50 \mathrm{ml}$ cone add with oaution $5 \mathrm{ml}$ of $70 \%$ porohlorio coid. Put on safety elessos or face shield and ovaporato solution by swirling oror a bunson flame until dense white fumos appoar. Continue gentle heating one minute. Cool. Dilute to $10 \mathrm{ml}$. Stir. Contrifuge off silioa ppt.

(3) Evaporato supornato to denso whito fumos agein. Cool. Cautiously add 15 ml absolute alcohol. $C_{001}$ in is e bath. Centrifuge. Dispose of supornate immodintely as it contrins ethyl pcrohlorato whioh is explosive when heated. Fash ppt twice with $5 \mathrm{ml}$ absoluto aloohol.

(4) Cesium perohlorato ppt may bo dissolved in distillod water. This is the final francium fraction. If plates aro made it pays to volatilize the francium to a socond plato by tho teohniquo dosoribod in $A(1)$ in order to got very smooth doposits.

A 30 minute bombardment of 3 thorium foils $1 /$ C $^{\prime \prime} \times 13 / 4^{\prime \prime} \times .005$ " workod up by Prooedure $B$ has produced $10^{7}-10^{10} \mathrm{c} / \mathrm{m}$ of 30 minute franoium 60 minutos after bombardmont.

*** The volatility of cosium and of franoium is bellevod to be caused by a disproportsonation of the oxide to peroxido and metal. The metal distills 3 tho poroxide decomposes to oxide and is recdy for a naw disproportiom tion.

Yiolds on the polatilization stop vary from $25 \%$ to $90 \%$ deponding on amount of solid present and other frotors. With plates containing only cesium, $75 \%$ hi-hor ylelds aro usually obtained.

**** Alcohol is added because of the insolubility of cesium perchlorate in this solvent. 
Element separated: Francium (oarrier froo)

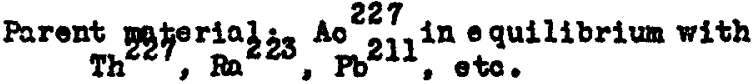

leilking Procedure

Yield, 40-50\%
Prooeduro by: J.M.Hollander IIm for sep'n: $1-2 \mathrm{hra}$. Equipmont required:

(1) Ion exohange column. 2 om long, 2 in in damoter.

(2) Dowex-50 aold form resin.

(3) Tro A1"sample mounting" plates, $31 / \mathrm{e}^{n} \times 21 / \mathrm{2}^{n}$. with a $5 / 0^{n}$ hole in the conter.

Dogree of purfifiontion: At loast a faotor of 50 from $\mathrm{Pb}$. Jther purifioations not dotormined (a's not oountod.)

\section{Prooedure:}

(1) The su should bo in $0.5-1.000$ of 2 Ero solution. Allow this solution to pass through the column, to adsorb the $\mathrm{Th}, \mathrm{AO}$, and partially the Ra.

(2) Elute with ${ }^{4}$ 00's of 2 I ENO (to bring off any Ra whioh hag adsorbed on the resin) at a $128 \mathrm{w}$ rate of about $0.5 \mathrm{ml} / \mathrm{min} . / 0 \mathrm{~m}^{2}$.

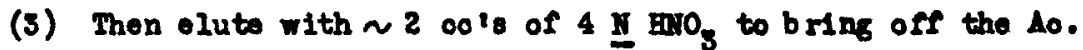

(4) Brap this 4 II Ao fraction to drynose in a contrifuge cone, then dissolve the residue in water. Allow to stand 50-60 min.

(5) Add $\sim 5$ mg $\mathrm{Pb}^{++}$oerrier, hoat the soln, ppt PbS by pasaing in $\mathrm{H}_{2} \mathrm{~S}$ gas to this solution as it 00018 .

(6) Centrifuge, roppt Pbs from the supernate.

(7) Braporate supernato to dzyness onto a Pt diso.

(8) This disc is set upon an aluminum plato and oentered above a $5 / \mathrm{B}^{\prime \prime}$ holo in this plate. An asbestos washor 1s placed above. On top of the asbestos washer and oovering the hole fust abow the sample plate is placed a seoond platinum diso, sootch tapod to a $1 / 8$ in. Al diso. The At d100, Pt diso oombintion is o00led with dry 100 while an oxygon toroh with a amall flame is tounhod to the bottom of the sample plate, hoating it strongly to rod heat for 5 seconde. The oooled oolleotor plate should then oontain most of the Fr. 
Element separated: Radium

Target material: Thorium ( 10 gm motal)

Type of bbdt: $184^{\prime \prime}$ full energy partioles
Procedure by: Hoinke

Time for sepin: $\sim 8 \mathrm{hrs}$.

Equipmont roquired: Standard plus centrifuges of: $250 \mathrm{ml}$ capaoity $50 \mathrm{ml}$ oapacity $15 \mathrm{ml}$ capacity

Tank HCl

Y101d: 25-50\%

Degree of purification: At least $10^{7}$ from thorium, and at least $10^{4}$ from other alpha activities prasent in high yield.

Advantages: Can be used to separate Ra with Ba carrier from large amounts of target material and (if coupled with colum separation) to give weightless fraction of Ra.

Procedure:

(1) Dissolve the thorium metal target in concentrated Bro, with drops of .2 If $\left(\mathrm{NH}_{4}\right)_{2} \mathrm{SiF}_{6}$ soln added to make the 801 'n $\sim .01 \mathrm{H} \mathrm{SiF}^{-2}$. (A largo becker ahould be used to prevent bubbling over in the vigorous reaction. The solution needs to be heated to start the reaction but onoe started the reaction proceeds vigorously.) Cont inue adding conc. $\mathrm{HNO}_{3}$ and $\left(\mathrm{MH}_{4}\right)_{2} \mathrm{SiF}_{6}$ solution until target oomplotely dissolves (may be an hour or tro for $25 \mathrm{mil}$ pieces of Th.)

(2) Bvaporate off most of HNo leaving $^{\mathrm{Th}}\left(\mathrm{NO}_{3}\right)_{4}$ orystals. Caution: Do not e vaporate to dryness or the nitrato will turn to $\mathrm{IhO}_{2}$ which is harder than the oricinal Th motal to dissolvo. If some $\mathrm{ThO}_{2}$ is aocidentally formed use the same combination of cono. $\mathrm{HWO}_{3}^{2},\left(\mathrm{MH}_{4}\right)_{2} \mathrm{SiF}_{6}$ and heat to dis8olve it. $\mathrm{ThO}_{2}$ is considerably easier to dissolve immodiately after forming than after prolonged heating and standing. (Soe 90-4).

(3) Add $6 \mathrm{mg} \mathrm{Ba}^{+t}$ oarrier to the orystals and dilute with water to $\sim 30$ co. Transfor to $250 \mathrm{ml}$ oentrifuge bottlo.

(4) Lad $\sim 16$ oo oono. $\mathrm{MP}_{4} \mathrm{OH}$ (preoipitating $\mathrm{Th}(\mathrm{OH})_{4}$ ) dilute to $200 \mathrm{cc}$ with water and digest for several minutes.

(5) Centrifuge and pour off supn (containing Ba and Ra plus other aotivities.)

(6) Dissolve ppt (amounting to $\sim 125$ oc rolumo) in $\sim 16$ oc oonc. $\mathrm{ENO}_{3}$.

(7) Add 3 mg $\mathrm{Ba}^{++}$carrier, diluto to $30 \mathrm{co}$.

(8) Add $\sim 20$ oo conc. $\mathrm{MH}_{4} \mathrm{OH}$ ppting the $\mathrm{Th}(\mathrm{OH})_{4}$ dilute to $N 200$ co with vator and digest for several minutes. 
(9) Centrifuge and pour of supn.

(10) Repoat stops 6 through 9.

(11) Combine the throe supernatants from steps 5, 9 and 10. Evaporato combined solutions until $\sim 200 \mathrm{co}$. volume and transfer to 350 ml cent. bottlo.

(12) Add 5 me Iat++ carrier and precipitato the La(OH) plus Th(Oت) from any $\mathrm{Th}^{+4}$ remaining by the addition of conc $\mathrm{WH}_{4} \mathrm{OH}$. Discard ppt.

(13) Evaporate the supn to $\sim 40$ oo and repeat step 12.

(14) Add $\mathrm{Na}_{2} \mathrm{CO}_{3}$ eolution to the supn to ppt $\mathrm{BaCO}_{3}$ (oarries Ra) digest for several minutes. Contrifuge.

(25) Dissolve $\mathrm{BaCO}_{3}$ ppt in minimum of cone. $\mathrm{HCl}$ (one or two oc's probribly onough)?

(16) Place in ice bath. Add coublo or triple volumo of ether and bubble in HCl ges until water and organio layers beoome misolblo and the pats out as the $\mathrm{BaCl}_{2}$. Contrifuge.

(17) Dissolvo the ppt in minimum of $\mathrm{H}_{2} \mathrm{O}$.

(18) Repect stops 16 and 17 twice (total of $3 \mathrm{BaCl}_{2}$ pptns). Caution: HCl-ether mixtures spatter roadily whon warmed.

(19) The $\mathrm{BaCl}_{2}$ can bs used for a counting or further purification can be mado using a resin colums.

Remarks :

Doually about $50 \mathrm{~ms}$ gf $5^{\mathrm{Th}} \mathrm{motal}$ oan be bombarded at onoe in the oyclotron to produce the Pa 225 . Henoe the large centrifugo is necessary for the separation of the original $\mathrm{Th}(\mathrm{OH})_{4}$ pptns and purifications.

The $\operatorname{Th}(\mathrm{OH})_{4}$ ppt is rory bulky-occupying more than half of the tubo in step 4. However, with the $\mathrm{Ba}^{++}$carricr added and the two reprooipitations of the thorium it is believod much of tho $R_{a}$ is rcoovered in tho supornatos.

The amounts of $\mathrm{NH}_{4} \mathrm{OH}$ and $\mathrm{INO}_{3}$ used should be calculated rather closely so as to allow fittlo excess, otherwise when the supn's are evapornted to $\sim 40$ oc (stop 13 ) the solution will be saturated wi th $\mathrm{NH}_{4} \mathrm{NO}_{3}$ and interfere with the $\mathrm{BaCO}_{3}$ pptns.

In step 23 some of the yield is lost through the solubility of some of tho $\mathrm{BaCO}_{3}$. This might be recovered by destroying tho $\mathrm{MH}_{4} \mathrm{NO}_{3}$ and roduoing the volum drastically before the carbonate procipitation. 
Originally and $\mathrm{Ca}$ wore addod as holdback oarriors in tho $\mathrm{Th}$ (OH) ppts. Tho $\mathrm{Ca}$, howc ver, did not soparato as woll from tho $\mathrm{Ba}$ as oxpootod in the later parts of the prooodure.

Thon working up $50 \mathrm{gms}$ of $\mathrm{Th}, 10 \mathrm{gms}$ at a timo, residues might bo combined and furthor recovory of Ba lost in the orlginal prooeduro might be Inde. 1180 the $\mathrm{BaCO}$ ppt of stop 14 (first $10 \mathrm{gms}$ ) oan bo dissolvod in cono. $\mathrm{HrO}_{3}$ and usod as 8arrier for tho various stops of sucooodine $10 \mathrm{gm}$ portions - thus reduoing the total amount of th in tho final semplo.

10 grams is about the maximum amount of thorium praction to work up at ono timo by this procodure using $250 \mathrm{ml}$ oentrifugo bottlos.

If oarrier froe $\mathrm{Ra}$ is nocded, $\mathrm{BaCO}_{3}$ oan be pptd from tho wator soin of the ond of stop 18. This $\mathrm{BCO}_{3}$ can bo dissolvod in aoid $\mathrm{pH} \mathrm{1-2}$ and absorbed on Dorex 50 resin. The $\mathrm{Sr}$, Ba \& an then bo olutod in that ordor by oitrato at $\mathrm{pH}$ 7.5-8.0 (So0 B. R. Tomplins ABCD-1998). This oolum procedure, howevar, has nct boen inoludod in the runs mado to date. 
88-2

\section{CHEMICAL SEPARATIOIS}

Element separated: Radium

Target material: $\sim 3$ G U metal

Type of bbdt: $184^{\prime \prime}$ high onergy part1cles
Procodure by: Folger

Tim for sep'n: $\sim 1-1 \mathrm{l} / 2 \mathrm{hr}$.

Equipmont required: Centrifuge, oones $(50 \mathrm{ml}-2 \mathrm{ml})$, ioo bath.

Y1eld: $50-75 \%$.

Dogree of purification:. $\sim 10^{3}$ from other eloments - sufficiont for mass spectrograph or ion exchange column.

Advantagos: Givos good yiold of Ra-Ba with only $\sim 75$ Hg carrier.

Prooedure:

(1) Dissolve target in small amount conc. Hro (heat if neofssary). Add $100 \mathrm{mg} \mathrm{Ba} \mathrm{(as} \mathrm{Ba}\left(\mathrm{NO}_{3}\right)_{2}$ carrior sol' $\left.\mathrm{n}\right)^{3}$ and $20 \mathrm{mg} \mathrm{sr}$ carrier (as nitrato).

(2) Add fuming FNO, to make up $\sim 25 \mathrm{ml}$ and chill in ico bath for 10 minutes. contrifuge out $\mathrm{Sr}\left(\mathrm{NO}_{3}\right)_{2}\left(\mathrm{C}_{\text {arries } \mathrm{Ba}}\right.$ \& $\left.\mathrm{Pa}\right)$.

(3) Dissolvo in $\mathrm{H}_{2} \mathrm{O}$, transfor to $15 \mathrm{ml}$ cono and buffer with HAc + $\mathrm{NH}_{4} \mathrm{Ac}(1 \mathrm{ml} 6 \mathrm{~N}$ HAO and $2 \mathrm{ml} 6 \mathrm{~N} \mathrm{NH}$ Ac or $\mathrm{pH} \mathrm{5-6).} \mathrm{Add} \sim 5 \mathrm{mg}$ $\mathrm{Pb}^{4}$ and ppt $\mathrm{PbCrO}_{4}$ by add ' $\mathrm{n}$ of $1.5 \mathrm{I}^{4} \mathrm{Na}_{2} \mathrm{CrO}_{4}$ to hot $\mathrm{sol}$ in. Thesh with hot HAC \& NHAO buffor ( $1 \mathrm{ml}$ to $2^{2} \mathrm{ml}$ as abovo) conteining 1 drop $1.5 \mathrm{II}_{2} \mathrm{Na}_{2} \mathrm{CO}_{4}$.

(4) Dissolvo ppt in hot $2 \mathrm{~N} \mathrm{HCl}$, pass in $\mathrm{H}_{2} \mathrm{~S}$ to roduco $\mathrm{Cr}_{2} \mathrm{O}_{7}=$ to $\mathrm{Cr}^{+3}$ and dil to $0.2 \mathrm{I}$. ppt $\overline{\mathrm{PbS}}$, soavonge with fow mg CuS.

(5) Boil out $\mathrm{H}_{2} \mathrm{~S}$, make basic with $\mathrm{MH}_{3}$ and ppt $\mathrm{SrCO}_{3}$ by adding $2 \mathrm{mg} \mathrm{Sr}$ and a fow drops $2 \stackrel{\mathrm{Ma}}{2} \mathrm{CO}_{3}$.

(6) Dis solve $\mathrm{SrCO}_{3}$ in 1 drop $6 \mathrm{~N} \mathrm{HCl,} \mathrm{boil} \mathrm{out} \mathrm{CO}_{2}$, buffer with $1 / 2$ ml $6 \mathrm{~N} \mathrm{HAO}$ and $1 \mathrm{ml} 6 \mathrm{~N}$ NH Ao (pH 5-6). Transfer to $5 \mathrm{ml}$ cono, adding not more than $1 \mathrm{ml}$ 会 0 . Heat to near bolling, add minimum $\mathrm{Fb}^{+2}$ to ppt $\mathrm{PbCrO}_{4}$ with 1 drop $1.5 \mathrm{~N}_{2} \mathrm{Na}_{2} \mathrm{CrO}_{4}$. Centrifugo.

(7) Dissolve $\mathrm{PbCrO}_{4}$ in 1 drop conc. HCl. Transfer to $2 \mathrm{ml}$ oone with $1 \mathrm{ml}$ HCl-ether rcagent. ChIll $10 \mathrm{~min}$. In 100 bath and oentrifuge out $\mathrm{BaCl}_{2} \cdot 2 \mathrm{H}_{2} \mathrm{O}$. Wash with $1 / 2 \mathrm{ml} \mathrm{HCl}$-othor reagent.

(8) Dissolvo in 1 drop $\mathrm{H}_{2} \mathrm{O}$ and add 1 drop $0.5 \mathrm{I} \mathrm{H}_{2} \mathrm{SO}_{4}$. Centrifugo out $\mathrm{BaSO}_{4}$ for mass spootrograph.

or (8a) Dissolv in 1 drop $\mathrm{H}_{2} \mathrm{O}$ and add 1 drop $0.5 \mathrm{~N} \mathrm{NaOH}$ plus 1 drop $2 \mathrm{H}$ $\mathrm{Na}_{2} \mathrm{CO}_{3}$. Contrifuge $\mathrm{BaCO}_{3}$ and dissolve in $\bar{O}_{.1} \mathrm{~N}$ HCl for equilibration with rosin for column run. 
Remarks: If the targot sol'n is obtained in large volume, buffer with $\mathrm{WH}_{4} \mathrm{Ao}_{\mathrm{O}}$ until uranium ppt's out. Centrifuge and ppt $\mathrm{PbCrO}_{4}$ from supernatant (20 mg or more may be requirod). Romore Po by dissolving the ohromato in 1-2 II HCl, pessing in $\mathrm{H} S \mathrm{~S}$, diluting to $0.2 \mathrm{II}$ and ppt'n PBS. After $\mathrm{H}_{2} \mathrm{~S}$ has been boiled out., the sol in may bo mado basio and $\mathrm{SrCO}_{3}$ ppt'd to foduce the volume. Follow with $\mathrm{Sr}\left(\mathrm{MO}_{3}\right)_{2}, \mathrm{PbCrO}_{4}$ and $\mathrm{BaCl}_{2} \cdot 2 \mathrm{H}_{2} \mathrm{O}$ ppt'ns.

For mass spootrograph work, steps 6 \& 6 may bo replaoed by:

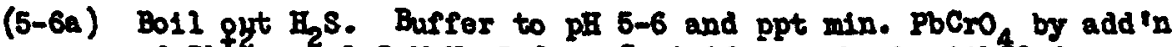
of $\mathrm{Pb}$ and $1.5 \mathrm{E} \mathrm{Ha}_{2} \mathrm{CrO}_{4}$. Cantrirugo. Wash with 2 drops

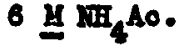

To remove oxoess almell salts adds

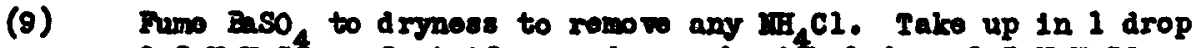
$0.5 \mathrm{I} \mathrm{B}_{2} \mathrm{SO}_{4}$. Contrifuge and rowash with $\mathrm{I}$ drop $0.5 \mathrm{II}_{2} \mathrm{SO}_{4}$.

Por resin column separation of $8 \mathrm{r}, \mathrm{Bh}$, and $\mathrm{Ba}$ seo $\mathrm{B}_{0}$ R. Tompld ne AECD-1998. Elute from rosin with oltrato at pll 7.6-8.0. 
Elomont soparated: Aotinium

(Procedure dosiened for $\mathrm{Ac}^{225}$ \& $\mathrm{AO}^{226}$ )

Procedure by: Hyde

Target material: Thorium motal

(Tro $25 \mathrm{mil}$ foils $1 \mathrm{l} / \mathrm{Z}^{\text {" }}$ aquare

Time for sep'n: 24 hours

hombarded on odgo) About 25 grams Th.

Typo of bodt: protons from 184"

Equipmont roquirod: boakers, oontrifuge oones, $250 \mathrm{ml}$ separatory funnol, resin oolum, automatic samplor, pH moter.

Yield: Not known - cstimated $75 \%$

Dogreo of puriflention: Comploto scparation from all other olomonts by faotor of at loast $10^{4}$.

Proocdure:

(1) Dissolvc thorium in hot cono. $\mathrm{HIO}_{3}$. Idd 1 drop 1 II HF ooccsionally to catalyze dissolution.

(2) Evaporato solution noarly to orystallization. Cool. Transfer to $250 \mathrm{ml}$ pear-shaped separatory funnel. Ono which hos been modifled to provido a sido funnel as shown in figuro 1 is rocomonded.

(3) idd 1-2 volumes penta other (dibutoxytotracthylono glycol)*. Stir. Lot sottlo. Drain aquoous laysr into orifinal bcakcr. Drain
pentaether layer into bottlo for storago.

FIg. 1

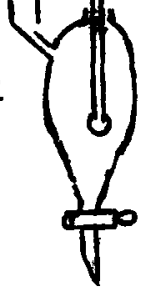

(4) Return aqueous layor to funno" Add solid ammonium nitrate with stirring until soluvion is saturatod. Add 2-3 volumes ponta thor. Stir. Drain aqueous into $50 \mathrm{ml}$ centrifugo cone. Drain pontaother layor into storago bottle.

(5) Ropeat pentaother oxtraotion onco again after adding $0.5 \mathrm{ml}$ conc. $\mathrm{FNO}_{3}$ to replace that extractod by solvent.

(6) Aquoous layer in $50 \mathrm{ml}$ centrifugo cono oontrifugod to separato last cc's of pontaother, which aro pipetted off.

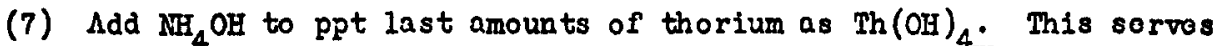
to carry the aotinium out of tho salted solution. Thash twioo with $\mathrm{H}_{2} \mathrm{O}$.

* It is quito important that the solution bo cool beforo the solvent is addod as pontaother is rapidiy docomposed by hot nitric acid.

** Pontacther is used to extraot tho bulk of the thorium away. The thorium scrves 28 its own salting agont in tho first pass whioh cxtracts the bulk of it and roducos tho aquoous volumo greatly. Subsoquent extractions must bo aided by $\mathrm{NH}_{4} \mathrm{NO}_{3}$ oalting. 
pago $2(89-1)$

(8) Dissolve mixed hydroxides in minimum smount HCl. Diluto to $5 \mathrm{ml}$. Adjus $t \mathrm{pH}$ to $1.5-2.5 * *$ ohook with Bockman $\mathrm{pH}$ motor using 1 drop glass electrodo. Add $10 \mathrm{ml} 0.15 \mathrm{li}$ ITA in bonzeno. Stir. Reohook and if nocossary readjust $\mathrm{pH}$. Stir woll 10-20 minutos.

(9) Contrifugo. Plpet off bonzone layer containing thorium.

(10) To aquoous add $10 \mathrm{ml}$ frosh TrA. Stir, ohook $\mathrm{pH}$. Stir 10-20 minutod. Contrifuge. Plpot off bonzone layor.

(11) To aquoous layor containing actinium, raro carth and othor activitios add $\mathrm{NH}_{4} \mathrm{OH}$ to adjust $\mathrm{pH}$ to botwoon $5.5-7.0 * * *$.

(12) Add $10 \mathrm{ml}$ TTA-bonzono. Stir. Rochook pH. Contact 20 minutes.

(13) Pipot benzenc layer containing aotinium and rare oarths into cloan $50 \mathrm{ml}$ centrifugo oonc. Ro-extraot aotivity into $2.5 \mathrm{ml} 0.2 \mathrm{I} \mathrm{ECl}$ by 2 minutes of stirring.

At this point the only likoly impuritios aro raro-earth $f$ is sion products. If theso do not interfore, this solution may be considored the final solution. If soparation from raro oarths is dosirod tho following resin separation is rooomendod.

(14) Add a fow of anmonium form colloidal dowox 50 resin to the dilute HCl solution. Tharm to $\cap 60 \mathrm{C}$ in water bath for $2-3$ minutos. Contrifugo.

(15) If assay of supo mate indicates ncarly comploto adsorption on resin, pipot the rosin on to the top of a short rosin column. Elute with 5\% citrate solution of $\mathrm{pH} 3.8-4.0$. Uso a meohanioal sauplor to tako samples ovory 20 minutos.

The rare oarth and actinium poaks oan not be prediotod acourately onough to el iminate the nocossity of al phe and botn oounts to dotermine their looation. The rare carth fractions como off in the first samplos as indicated by the pgta counts. Tho notinfym peak is looatod by the gl pha oounts of $\mathrm{Ac}^{225}$. The olution of $\mathrm{Bi}$ and its assooiated $P_{0} 213$ daughtor al pha aotivity in tho oarly fractions obsourcs the location of the actinizup poak unlose samplos aro pulse analyzed or unloss the 47-minute $\mathrm{Bi}^{213}$ is allowed to dooay beforo counting.

If exporionoc with a oolum 6 om $\times 2$ of colloidal resin olutod with pH 3.9 oitrate at a rato of 1 drop por 2.5 minutos was that tho raro oarth fraction camo off within two hours and tho aotinium fraction, well separatod from the rare oarths, started to oomo off aftor 5 hours and was sproad ovor 2-3 hours. Othors (Orth \& Stroot) roport moch more rapid elution undor ossontially the same conditions.

*** An oqual volumo of TIA-boneono will extraot thorium essontially oomplotely from an aquoous solution of $\mathrm{pH}>1$. Aotinium oxtraotion is 0 at $\mathrm{pH} 2.5$ or loss, is $10 \%$ at pH 4 and risos sharply to ossontially oomple te oxtraction at pH 5.5 or grontor. Soe Hagomann $\triangle B C D 2850$.

$7 / 6 / 49$

$P=18-46$ 
CH MICAL SIPAPATIONS

Element separated: Aotinium

Porent material: Tracer $\mathrm{Pa}^{230}$

Milking experiment
Procedurc by: Meinke

Time for sep'n: $3-4$ hrs.

Equipment required: śtandard, centrifuge

Yield: $\sim 40 \%$

Degree of purifioation: Factor of ut least $10^{7}$ from $\mathrm{Pa}, \mathrm{U}$ and $\mathrm{Th}$.

Advantages: Can separate very small amounts of Ac from largc amounts 6 of $\mathrm{Pa} \mathrm{U}$ and $\mathrm{T}_{\mathrm{h}}$ eotivity In one experiment separated $500 \mathrm{~d} / \mathrm{m} \mathrm{Ac}$ from $10_{226}^{7}$ tal a/m of $\mathrm{Pa}$ and about equivalent amounts of $\mathrm{U}$ and 30 minute

\section{Proooduro:}

$\mathrm{Pa}^{230}$ in $6 \mathrm{~N} \mathrm{HNO}_{3}$ after DIPK extractions (procedure 91-1)

(1) Take 10 co of $\mathrm{Pa}$ soln and add $1 / 4 \mathrm{mg} \mathrm{La}^{+++}$and $5 \mathrm{mg} \mathrm{Ce}{ }^{++}$oarriers.

(2) Add 10 drops of oone HF to ppt the fluorides. Centrifuge.

(3) Wtathesize ppt to Ia and Ce hydroxides by adding several $\mathrm{ml}$ of cono KOH soln. Centrifuge out the hydroxides and wash onoe with $5 \mathrm{ml}$ alkaline water.

(4) Dissolve ppt in few drops $6 \mathrm{~N} \mathrm{HCl}$ and dilute to $5 \mathrm{co}$

(5) Add $1 / 4 \mathrm{mg} 2 \mathrm{r}^{+4}$ oarrior and $\mathrm{H}_{3} \mathrm{PO}_{4}$ to make $3 \mathrm{~N} \mathrm{PO}_{4}^{-3}$. Discard ppt. Steps 2 through 5 are repeated alternately or conseoutively until the desired degree of purification is obtained. For the purifications noted abovo, 10 fluoride pptas and 9 phos phato pptns wero made. After the loth fluoride ppt had been metathesized to the hydroxide, the following procedure was usod:

(6) Dissolve hydroxide ppt in $10 \mathrm{~K} \mathrm{HNO}_{3}$, make $.01 \mathrm{y} \mathrm{Fo}^{++t}$ and oxidise $\mathrm{Co}^{++}$to $\mathrm{Ce}^{++++}$ith solid sodjum bismuthate (rarm to speod up reation.) ( $\mathrm{Co}^{+}$will now oarry on the $\mathrm{Zr}_{3}\left(\mathrm{PO}_{4}\right)_{4}$ ppt.)

(7) Bopoat stop (5).

(8) Ropeat (2) and (3).

(9) Dissolvo ppt in few drops 6 II HCl, dilute to known volume and plato aliquot for counting. 
Remarice :

The fluoride eycles decontaminate primarily from $\mathrm{Pa}$, the phosphate from $\mathrm{th}$. If further purification is required include more cyoles in prosodure.

Only one milking oan be made from a given batch of Pa by this procodure sinoe it is difficult to again get the $\mathrm{Pa}$ into an oxtractable form onoo fluoride ion has been added.

It has been found that the $\mathrm{LaCl}_{3}$ solution makes a pore adherent and thimer plate than the IaF, ppt. The amount of $\mathrm{La}^{7++}$ carrior used in etop (1) should bo determined by the amount of bulk that can bo tolerated on the final plate. 
$90-1$

\section{CHEMICAL SEPARATIONS}

Elomont separated: Thorium

Procoduro by: Noinke

Target material: Tracor $\mathrm{Pa}$ so paratod from $60^{n}$ bbdt of ionium.

Time for sop'n: Several hours.

Type of bbdt: (lislking expt.)

Equipmont roquirod: Stzrrors and TRA

Yield: As high as 50\% possiblo.

Degroo of purification:. Decontaminato from $10^{7} \mathrm{c} / \mathrm{m} \mathrm{Pa}, 10^{6} \mathrm{o} / \mathrm{m} \mathrm{U}$ and $10^{3} \mathrm{o} / \mathrm{m}$ Ao.

Advantsagos, Givos oarrier-froe $T h$, a thin plato for pulse analysis and good purification al though not speed.

Procedure:

(1) Nitrio acid used throughout. Kako samplo $6 \mathrm{~N}$ acid and TTA oxtract (with .4M TTA in boneene) 5 times with double volume of TTA -- stirriñg 5 minutos for coch extraction. (Removos Pa into ITA $\sim 70 \%$ or more per pass).

(2) Evaporate to dryness (wash twioe with water and take thosa washings also to drymoss) and take up in acid pH 1.0. TTA extraot with equal volumo (.25M TT in benzono) stirring 15 minutes. (Th into TTA but not $\mathrm{U}$ or Ac.)

(3) Repeat ITA oxtn of (2) with fresh TIA and combine the extns.

(4) Fash TTA with equal rolusiso of pH 1.0 soln for 15 min. (U contamina tion into acid.)

(5) Hash ITA with 6 N aoid (equal volumo) and stir $15 \mathrm{~min}$. (Th into acid).

(6) Repoat parts (2), (3), and (4). (Ropeat wash as in (4) if necessary for furthor 0 purifioation.)

(7) Plate out the .25 II TTA on Pt plates and flame.

Romarks: See curvos of Hagemann for $\%$ extn into TTA vs $p H$ for Th and Ao. At $\mathrm{pH}$ of 1 should go into the TIA almost completely but 0 should only $g 0$ in less than $10 \%$-. perhaps as little as $2 \%$. Ao will not go into TIA until about $\mathrm{pH} 3$ or so and of course $\mathrm{Pa} \mathrm{gOes}$ in up to about 6 or an aoid.

pH conditions for soparating Th from $U$ by TTA extns are quito oritioall

Equivalent and moleoular weight of TIA'is $222 \mathrm{gms}$. 
Elomont separatod: $\mathrm{Wr}_{1}$ (Thorium)

Targot matorial: $\quad \mathrm{HO}_{2}\left(\mathrm{NO}_{3}\right)_{2} \cdot 6 \mathrm{H}_{2} \mathrm{O}$ is whioh $\mathrm{WX}_{1}$ has come to equilibrium
Prooodurc by: D. B. Stcrart

Timo for sop'n: 24 hrs.

Equipment required: $40 \mathrm{ml}$ contrifuge cono

Yiold: $50,000-10,000 \mathrm{c} / \mathrm{m}$ from 20 G 0 H.

Dogroo of purification: factor of $\backsim 10^{6}$ from 0 .

Ldvantagesi Good yiold with small amount of inort carrier (Vory voluminous 1asolublo preoipltate) (Uranium does not preoipitate at ali)

Procoduro:

(1) Dissolvo $20 \mathrm{~g} \mathrm{VO}\left(\mathrm{NO}_{3}\right)_{2} .6 \mathrm{H}_{2} \mathrm{O}$ in $20-30 \mathrm{ml} 0.01$ H $\mathrm{HNO}_{3}$ in a $10 \mathrm{ml}$ oontrifugo oonc and wain solution to about $80^{\circ} \mathrm{C}$ in a hot wator bath. Idd 0.5 mg - 1 mg osrrior as nitrato.

(2) Add $5 \mathrm{ml}$ of a saturatod solution of m-nitrobonsoio acid in wator and oontinue warming for about $1 \mathrm{hr}$. Lot stand overnight.

(3) Contrifuge, dooant supo rnatant, and wash $\mathrm{Zr}\left(\mathrm{C}_{6} \mathrm{H}_{4} \mathrm{HO}_{2} \mathrm{COO}\right)_{4}$ twioo with $0.01 \mathrm{~N} \mathrm{mrO}_{3}+\mathrm{m}-\mathrm{HI}$ trobenzolo ac1d.

\section{Remarios :}

Saturatod solution of m-nitrobenzoio aoid mado up by dissolving 400 mg. of the matorial in $100 \mathrm{ml} \mathrm{H}_{2} \mathrm{O}$. Heat to $80^{\circ} \mathrm{C}$. Allow to stand sovoral hours \& flitor to romove exooss and impuritics. 
Elomont soparated: Thorium

Pcront matorial: Traoor $\mathrm{Pa}$ and daughtors (both a \& $\mathrm{K}$ )

iflking oxporimont
Proocduro by: Minko

Timo for sop'n: $3 / 4 \mathrm{hr}$.

Equipmont roquirod: standard

Yiold: only $\sim 40-50 \%$ Th por cyolo

Dogroc of purification: 2-3\% Ac oarriod por oyolo - other olements dooontaminatod by factor of at loast 100 .

Advantages: Good procodure if Th prosont in $\sim$ sano amount as othe $r$ activitios.

Proooduro:

Fa daughtors in $6 \mathrm{~N}$ ECl aftor milking from $\mathrm{Fa}$ in $\mathrm{TM}$ (91-1).

(1) To $\sim 10$ oo daughtor soln add $1 / 2-1$ mg $2 r^{+4}$ carrior and ono:gh

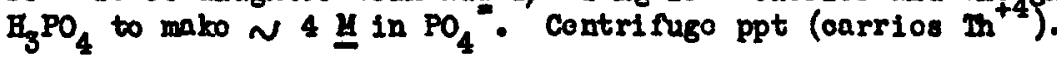

(2) Add to tho ppt $3 \mathrm{mg} \mathrm{La}^{+++}$carrior and diluto with $1 \mathrm{I} \mathrm{ECL.} \mathrm{Add}$ EI, digost and oontrifugo.

(3) Wotathoeizo tho fluoride ppt to hydroxide by adding cono KOH. Contrifuge. Wash onoe with allenline vater.

(4) Dissolvo in BCl and ropoat stops 1-3 reducing amount of La carrior.

(5) Pla to as tho $\mathrm{LaCl}_{3}$ soln, Mlame and count.

Rom ries :

$2 r_{3}\left(\mathrm{PO}_{4}\right)_{4}$ ppt quito s pocifio for carrying $\mathrm{Th}^{+4}$ from othor olcmonts in the hoavy rogion. Ylold lost in the $\mathrm{LaF}_{3}-\mathrm{La}(\mathrm{OH})_{3}$ pptns.

Do not uso this proooduro if moro purifloation uoodod than givon by 2 oyolos sinco tho Th fiold will bo vory low.

$\mathrm{LaCl}_{3}$ soln when ovaporatod sticks to Pt plates much bettor than tho ppts onoountorod in this pronoduro.

$8 / 1</ 49$

P-18-151 


\section{Solution of Thorium tiotal and Thorium Dioxido}

Thorium motal oan be dissolved rapidly in oono $\mathrm{HCl}$ but a considorable amount of black insoluble residue is fo med in tho process. If a few drops of $\left(\mathrm{MH}_{4}\right)_{2} \mathrm{SiF}_{6}$ solution (onough to make $\sim 0.1 \mathrm{M}$ ) aro added to the HCl beforo solution is 6 tarted tho black residuo is dissolvod, loaving only a small residue of thorium oxido $(<1 \%)$ in the oloar solution.

Thorium motal can be Aissolvod in conc. $\mathrm{HHO}_{3}$ with the addition of $\left(\mathrm{NH}_{4}\right)_{2} \mathrm{SiF}_{6}$ (Or IF) to .01 if. The metal bocomes pessive to the solution from time to time requiring further additions of acid and $\mathrm{Si}_{6}{ }_{6}$.

If the oxooss $\mathrm{HNO}_{3}$ is oraporated off caro should be taken not to allow the solution to go completely to drymess or difficultly solublo $\mathrm{ThO}_{2}$ will be formod.

If it is desired to dissolve $\mathrm{ThO}_{2}$, the $\mathrm{HNO}_{3}-\left(\mathrm{NH}_{4}\right)_{2} \mathrm{SiF}_{6}$ solution should bo used and the mirture heatod with stirring for several hours. $\mathrm{ThO}_{2}$ when first formod is much more soluble than after prolonged heating.

Note: A bombardment of $50 \mathrm{mg} 13 \%$ ionium $\left(\mathrm{Th}^{230}\right)$ in thori um ( $\mathrm{Th}^{232}$ ) mixture in the dioxido form should be mentionod here. The hydroxide was pptd and hoated in a Pt oruoible until only the dioxide romained yrifis dioxide was then packod into a Pt "bont" $1^{\prime \prime} \times 1 / 2 " \times .085$ " and wot a lew drops of sodium silioato soln. Tho mixturo was then dried under a hent lamp, moro silicate added and again dried. The boat was thon flamed over a Fishor hurner.

It vas found that a target propared this way could withstand considorablo mochanical shock and also the high targot temperature produood by tho 60" oyclotron deutiron beam uithout breaking the silioa orust.

It yas also found that the targct matorial could be rather easily scraped out of the boat and mostly dissolved in 5 or 6 hours -- after sereral udditions of $\mathrm{HNO}_{3}{ }^{-} \mathrm{SiF}_{6}=$ soln.

Nowton. Hyde, Iseinko

$$
8 / 15 / 49
$$

P-18-2C2 
Eloment separated: Protactinium

Targot marial: $\sim 10 \mathrm{Ems}$ Th me tol

Time of bbdt: $60^{\prime \prime} \mathrm{D}^{+}$bbdt and $284^{\prime \prime}$ bbdt a.11 partioles

Yiold: Roughly 10\% through ontir o ohoni stry

Degroo of purifioation: Separate from all eloments by a faotor of at least $10^{3}$. For further purifioation from Cb and $\mathrm{Zr}$ do moro DIPK washes.

Advantages: Gives carrier-free Pa on weightless plates for pulse analysio and counting. Puriflcation oan be made moro extensive by ropenting Individual stops.

Procodure:

(1) Nitrio acid used except whore indicated otherwise. Dissolve Th motal in oono. $\mathrm{HrO}_{3} \sim .01 \mathrm{M}$ in $\left(\mathrm{MH}_{4}\right)_{2} \$ 1 F_{5}$ soln (25 00 aoid añd 3 or 4 drops of $1 / 5$ ISIF oln usually euffioiont to dissolve 10 gms Th.)

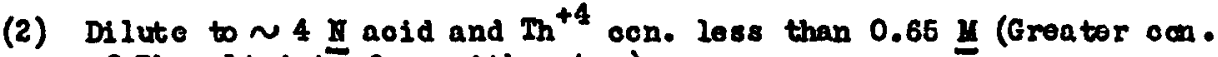
of Th salt intorfors with pptn.)

(3) Add to $4000 \mathrm{Th}\left(\mathrm{NO}_{3}\right)_{4} \operatorname{soln~in~} 4 \mathrm{~N} \mathrm{BNO}_{3}$ an oxcoss of $\mathrm{kn}\left(\mathrm{NO}_{3}\right)_{2}$. (1/2 oo of $50 \%$ solg suffioient.)

(4) Add $1.500 \operatorname{mono}_{4} \mathrm{soln}(40 \mathrm{mg} / 00$ ). (Pa carriod quantitatively on $1.5 \mathrm{gm} / 1$ iter ${ }^{4} \mathrm{HnO}_{2}$ ppt.)

(5) Digost ovor mator bath, oontrifuro and pour off suph.

(6) To ppt. add fow drops of $4 \mathrm{I}$ actd and diesolve in a fow drope of sat. soln of $\mathrm{Mg}_{2} \mathrm{OH} \cdot \mathrm{BCl}$.

(7) Dilute to roquirod rolum and repeat pptas. throo timos.minicing volume oach timo. F inal volumo is a for $00^{\prime} 8$.

(8) Vake soln $6 \mathrm{H} \mathrm{HO}$ or HCl. Extraot with 2-3 timos volums of di. 18opropyl kotono (DIPK) amking togothor for $1 / 2 \mathrm{~min}$. In Kjeldahl rlasks and soparating phasos by froozing aquoous layer with dry ioe - coc tono mixturu. (Fa into DIPK $\sim 60 \%$ ylold/pass).

(9) Wash DIPK layor with 3 washs of an equal volumo of ooln 1 I $\mathrm{BHO}_{3}$ and $3 \mathrm{I} \mathrm{NH}_{4} \mathrm{NO}_{3}$ in suocessivo rlasks.

(10) Pa thon rashed into 2 succossive dortions of .I I $\mathrm{ENO}_{3}$. 


\section{1-1 (pago 2)}

(11) DIPT extn repeated once and .1 IN solns combined and made 6 N $\mathrm{HNO}_{3}{ }^{\circ}$

(12) Equal volume of ITA (.4 II in bonzone) stirred for 5 min. with the 6 N aoid - (Pa into TrA.)

(13) Organic layer washed onco with oqual volume 6 패 $\mathrm{HNO}_{3}$.

(14) The Bonreno-TTA plated out on platinum.

Romarks: The am't of $\mathrm{F}^{-}$introduoed by the $.02 \mathrm{M}\left(\mathrm{NH}_{4}\right)_{2} \mathrm{SiF}_{6}$ is not onough to complox an appreoiablo amount of the $\mathrm{Pa}$. Traoos of $\mathrm{Pa}+40 \mathrm{ppt}$

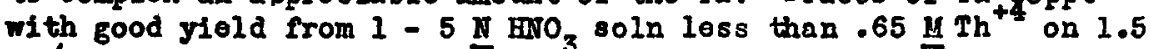

em/liter $\mathrm{lnO}_{2}$ with good separation from macro am 't of Th. A concentration foctor of at least 10 can bs obtained by those pptn oyoles.

Any Th and fission product that oxtract into DIPK are washod out in the acid-salt washos. $0.1 \mathrm{NH} \mathrm{HNO}_{3}$ used to wash $\mathrm{Pa}$ out of DIPK koepo $\mathrm{Pa}$ from hydrolyzing to the collold state.

The Pa must never get very noar a noutral pH or it will go into the non-oxtraatable oolloid.

TTA soparatos $\mathrm{Pa}_{\mathrm{a}}$ from all elemonts formod in bbdt except $\mathrm{Zr}$, $\mathrm{Cb}$, and Ef. DIPK extracts only $\mathrm{Pa}$ and $\mathrm{J}$ at theso ocns. $\mathrm{MnO}_{2}$ oarries $\mathrm{Pa}$, $\mathrm{Zr}, \mathrm{Cb}$ and maybe some others, but does eliminato things liko I whioh might solvent extract through the other ohemion prooodures. 
Element separated: Protactinium

Target material: $\operatorname{Th}\left(\mathrm{NO}_{3}\right)_{4}$ or thorium motal

Type of bbdt: $60^{\prime \prime} \& 184^{n}-$ all particles

Yield: $\quad 40-80 \%$

Degree of purification: except $\mathrm{zr}, \mathrm{Cb}, \mathrm{HF}$.

Advantages, Fast, weightless plate $4 \mathrm{~Pa}$, good for alpha pulse analysis. Zr \& Cb fission products coming through procedure make Geiger counting of Fa impossible wi thout more chemistry.

\section{Procedure:}

(1) Dissolve $\mathrm{Th}$ motal in conc. $\mathrm{HNO}_{3}, 0 \mathrm{OI}$ in $\left(\mathrm{NH}_{4}\right)_{2} \mathrm{SiF}_{6} \mathrm{soln}$. (25 co. aoid and 3 or 4 drops of $1 / 5 M M^{3} i F$ sol'n sufflcient to dissolvo

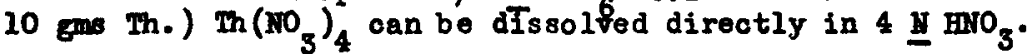

(2) Dilute to $n 4$ I acid.

(3) Add equal volume of TTA (.4 y in benzene) and stir for 5 minutes. $(\mathrm{Pa}, \mathrm{Zr}, \mathrm{Cb}$ into organio la yer $)$.

(4) If want somowhat better purifioation wash TTA layer with equal volume of 4 II $\mathrm{HMO}_{3}$. (Bhy lose up to half $\mathrm{Pa}$ yield in this wash.)

(5) Plate out bencene-TTA layer on platinum.

Pemarks: TA separates Pa fromall elements formed in bbdt exoept $\mathrm{Zr}$, Ch, \& Hf.

This method used for excitation funotion work where as many as 16 foils are worked up 8 imultanecusly. Identical amounts of reapents are added and each sample subjected to the samo procedure, giving approximately equal chomioal yields for each foil (to within 5 or 10\%).

$6 / 22 / 49$

$P-18-5$ 


\section{CHEYICAL SEPARATIOAS}

Element soparated: Protactinium ( $N 2 \mathrm{mg}$ )

Removal of maoro amounts of $\mathrm{Pa}$ from rare earths, Mn, Zr, Iron

Yield: N $80 \%$

Advantages: Takes Pa out of colloidal state
Prooedure by: Crane

Time for sep'n: Several days

Equipment required: anion exchange. resin, beskers, hot plate, centrifuge

Prooedure:

(1) Add ten times as much $\mathrm{Zr}^{+4}$ as you have $\mathrm{Pa}\left(\sim 20 \mathrm{mg}\right.$ of $\mathrm{zr}^{+4}$ ) make $3 \mathrm{H}$ in HF and allow to stand for several hours. Then add excess $\mathrm{Ba} F 2$ IOn; Pa carries on the BazrF 6 Ppt.

(2) Cheok floride solution for Pa activity. If carrying not complete add I. $\mathrm{Zr}^{+4}$ and digest at low temperature for a fow hours.

(3) Combine BaZrF 6 + Pa ppts and dissolve in conc. $\mathrm{HNO}_{3}+$ borio acid.

(4) Dilute and preoipitate $2 r+$ Ps as hydroxide with KOH.

(5) Redissolve ppt in oono. BCl. Botl this solution for a few hours then mate HCl 8 II and absorb on anion exahange resin (Dow A-1 used in $20 \mathrm{~cm} \times \mathrm{I} \mathrm{cm}^{2}$ colum; flow rate $\sim 1$ drop/min). Tash resin with 8 MCl.

(6) Elute with 4 H HCI. Pa will come off in $N 15$ oolumn volumns. (Uranium requîres $\sim 45$ colum volums).

Alternate step for (f): Tf desired and solution of Pa does not contain too much $\mathrm{Zr}^{+4}$ and other floride complex ions the $\mathrm{Ph}$ solution may be absorbed direotly on the resin from a 3 ․ BF soln, washed with conc ICl/eluted with $4 \underline{H} \mathrm{HCl}_{1}$.

(7) Final solutions of $\mathrm{HCl}_{1}$ are then ooncentrated, made $6 \mathrm{H} \mathrm{HCl}$ and Pa extraoted into equal volum disopropyl ketone.

(8) The $\mathrm{Pa}$ is taken baok into .1 volume 0.1 E ErO ${ }_{3}$ solution and mado $4 \underline{\mu}$ in HCl to keop Pa from forming oolloid.

\section{$8 / 17 / 49$}




\section{CHMIICAL SEPARATIONS}

Element separated: Uranium

Parget material: u20 $\mathrm{gm}$ of $\mathrm{Th}$ metal

Type of bbdt: $184^{n}$ bbdt
Procedure by: Crane

Time for sep'n: Several hrs.

Equipment required: Contrifuge, Kjeldahl flasks. dry ice and stirrers.

Yield: in 90\%

Degree of purification: Separate all elements in Th fission by faotor groater than $10^{\circ}$.

Advantages: Gives carrier fres Uranium.

Procedure:

(1) Nitric acid used except whore indicated otherwise. Dissolve Th tal in cono. $\mathrm{HNO}_{3} \mathrm{k}_{-} \backsim .0 .2 \mathrm{M}$ in $\left(\mathrm{NH}_{4}\right)_{2} \mathrm{SiF} \mathrm{F}_{6}$ (50 oc acid and $\backsim 6$ drops $1 / 5 \mathrm{M}$ SiF $_{6}-$ Solution usualify sufficiont to dissolve 20 gram Th metál).

(2) Evaporate to near dryness \& redissolvo in $1 \mathrm{M} \mathrm{HrO}_{3}$ and saturate with $\mathrm{MH}_{4} \mathrm{NO}_{3}$.

(3) Ether extract uranium using 3 separate portions of ether and combining; wash twice with $.1 \mathrm{u} \mathrm{HrO}_{3}+20 \mathrm{M} \mathrm{MH}_{4} \mathrm{MO}_{3}$.

(4) Extract uranium back into water solution. Add $\mathrm{Ia}^{+++}$carrior $\sim 1 \mathrm{mg} / \mathrm{co}$ solution

(5) ppt hydroxide with $\mathrm{NH}_{4} \mathrm{OH}$. (oarries uranium) (6) Dissolve in $6 \frac{\mathrm{M}}{\mathrm{HrO}_{3}}$ and add $\mathrm{Zr}^{+4}$ soavenger ( $\mathrm{n} 1 \mathrm{mg} / 00$ ),
dilute to $3 \mathrm{~N}$ acid.

(7) Add lodic acidd to ppt $2 \mathrm{KO}\left(\mathrm{IO}_{3}\right)_{2}$ to scavenge solution.

(8) Remove supernatent and ppt $\mathrm{Ia}^{+3}$ as hydroxide.

(9) Dissolve in $1 \mathrm{M} \mathrm{HMO}_{3}$. Saturate $\mathrm{with} \mathrm{MH}_{4} \mathrm{MO}_{3}$ and other extract using $\overline{3}$ separate portlons of other and combining.

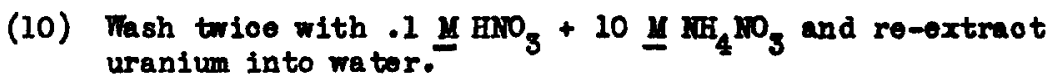

Remarks: Use one part other, two parts salt solution in extraction. Wash with equal volume salt solution. Re-extract into half volume water.

In step 7 do not add excess iodic acid or La will also be pptd. Add just enough to ppt the $\mathrm{Zr}$ as $\mathrm{ZrO}\left(\mathrm{IO}_{3}\right)_{2}$, otherwise much yield will be lost. For ether extraction of uranium seo: $6 / 16 / 49$ A. S. Nevton, Phys. Rev. 75209 (1949). 
Determination: Aoid equivalent, 1.0., $\mathrm{B}^{+}$\& oarboxyl

Trsget Alorial: Aloohols (othanol)

Type of bbdt: 10 Mor p

Iiold: quantitativo

Degree of preolsion: $\pm 1 \%$

Prooedure:
Procedure by* Wewton \& UDDonell

Timo : 10 min.

Equipant roquired: buretto Glassware

(I) Dilute 500 of Irradiated sample to 20 o0 with water or noutral othanol.

(2) Add 3 drops $2 \%$ phonolphthaloin indicator solution.

(3) I1trato with 0.1 II HaOB to sharp phonolphthaloin end point.

(4) Aold oquivalonts = vol. of alknli $x$ normality.

\section{Romarks:}

A blank should be run on the ethanol to insure noutrality. Other substanoes besides free $\mathrm{B}^{+}$and oarbonyl thnt titrato rast

with FaOH include soveral phenols, laotones (inner esters), ana some esters. These must be dotermined by further analysis.

Referonoos: Standard Organic Amalyses Texts

$8 / 12 / 49$

P-18-157 
Substanoe determined: Carbonyl

Target material: Alcohols (othanol)

Typo of bbdt: $p(\sim 10 \mathrm{Hov})$

\author{
Procedure by: Newton \& \\ Ho Done 11 \\ Time for sopin: one diny \\ Equipment required. \\ Pyrex tos's tubes \\ burettes, pipettes \\ stean bath
}

Yield: Quantitativo prooise to $\pm 1 \%$

Proooduro:

(1) To $5 \mathrm{co}^{(1)}$ (pipette acquraoy) of irradiated aloohol add 3 co hydroxylamine rociegt (pipette acouracy) and 5 co of buffered indicator reagent (graduated oylinder). Treat a blagk of 5 oc absolute aloohol identically in all steps. Senl in a Formbstubo.

(2) Heat in steam bath 2 hours (1). Nllow stand to cool ovornight.

(3) Break the bomb tubc, rinse quantitatively into a flask with measurcd portions of $95^{\prime \prime}$ ethanol. Treat blank idontically.

(4) Titrato samplo to the crecnish blus ond point color of the blank (or titrate both samplo and plant to s:me end point color) with alcoholio $05 \mathrm{~N}$ NaOH soln.

(5) Cale. equivalent $\pi t$. of acotaldohyds from the differenoe in titres of blank and somplo, assuming the titration is a hydrogen dotrimin:ation by the reaction:

$$
\begin{aligned}
& \mathrm{H}_{3} \mathrm{C}-\mathrm{C}-\mathrm{O}=\mathrm{O}+\mathrm{H}_{3} \mathrm{~N}^{+} \mathrm{OH} \longrightarrow \rightarrow \mathrm{H}_{3} \mathrm{C}-\mathrm{C}=\mathrm{NOH}+\mathrm{H}^{+}+\mathrm{H}_{2} \mathrm{O} \\
& \mathrm{H}^{+}+\mathrm{OH}^{-} \longrightarrow \mathrm{H}_{2} \mathrm{O} \quad(8)(9 \text {. }
\end{aligned}
$$

Romarks:

(1) About 0.001 moles of carbonyl is maximum samplo size for tho specified reagont quantitios.

(2) Ereparo 0.5 hydroxylamine solution by dissoloing $35 \mathrm{~g}$ of hydroxylamino hydroohlorido in 160 oo of dist water and diluting to 1 lites with $95 \%$ othanol.

(3) Proparo bufforcd indiontor $80 \mathrm{In}, 20$ oo C.P. pyridine to $1.0 \mathrm{co}$ of 1 peroont alooholio brom phenol blue indioator and diluting to 500 co with 95\% othenol. 
Organic-carbonyl

(Page 2)

(4) Exoessivo heating ( 5 hrs.) causes a breakdown of the hydroxylamine salt with inaoourcto results.

(5) Alconolic $0.5 \mathrm{~N}$ NaOB is propared with $90 \%$ mothanol rather than ethanol, since the lattor oxidizos in air, producing an aldehydo whioh resinifios in baso, coloring the soln. Standardize ro standard HCl.

(6) The wator content must be nearly idontical in blank \& samplo, sinco it affocts indioator color and buffer aotion of pyridino.

(7) The and point colors may bo matchod to an aocuraoy within a fraction of a drop, $1.0 . \pm 0.02 \mathrm{ml}$.

(8) The pyridine buffor allows effootivo titration of libornted $\mathrm{H}^{+}$ without interferenoe from excoss $\mathrm{H}_{8} \mathrm{I}^{+} \mathrm{OH}$.

(9) Ref. Bryant \& Smith JACS 57, 67 (1935).

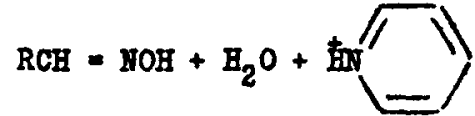


Determination: Saponifioation Equivalent (esters)

Targot materin1: clcohols (cthnnol)

Type of bbdt: $p$ (10 Mav)
Procedure by: Norton \& roDonell

Time for sep'n: 1 day

Equi pment roquirod: glassware 8 toam bath

Yield: Oual: tative only

Procedure :

(1) Senl 5 oc irradiated semplo +2 oo $\mathrm{NaOH} s 0 \mathrm{ln}(1)$ in Pyrex glass test tube.

(2) Heat for $2 \mathrm{hrs}$. with occasional agitation in a steam bath. Troat a blank ethanol samplo identically.

(3) Cool tubos, break cand rinse into benker. Add oxcess stagygry acid. Titrate with stancard NaOH to phenolphthelein ond point $\left.{ }^{2}\right)$.

(4) Difference in quantity Ne.OH between blank and sample as doterminod in the (t) ostor.

Remorks :

(1) $\mathrm{NaOH}$ solution made by diluting $20 \mathrm{~N} \mathrm{aq}$. HnOH to I N with absolute ethnnol.

(2) Presence of aldehydes causes brown discoloration (oondensation rosins) of irradiated samples and yellow in the blank. Considerable dilution io nocossary to enablo an accurate visual ond point dotermination.

(3) Alknli consuming interferences include Cannizzaro renotion on aldehydes. Poly functional compounds such $a_{5} \beta$-diketones and $B-k e$ to esters undergo clestrage, eto.

(4) It is omphasized that this prooedure comprises merely a qualitative test for the obsily saponifiable esters (ethyl acotato, ethyl formate, mothyl acotate, eto.) expeoted in othanol bomivardments. For accurate determination in the presence of aldehydes, or for difficulty saponifiable osters, considerable refinement in procedure is neoessary. Rof. Shriner and Fuson "Systematio Ident. of Org. Cpds."John iflloy i Sons, Now York, 1948. p. 128 and other standard organic analysis texts.

$8 / 12 / 49$

END OF DOCUNENT

P-18-155 